On the Urbanisation of Cross-border Mobility Controls - A Case of Roma 'EU Migrants' in Malmö, Sweden

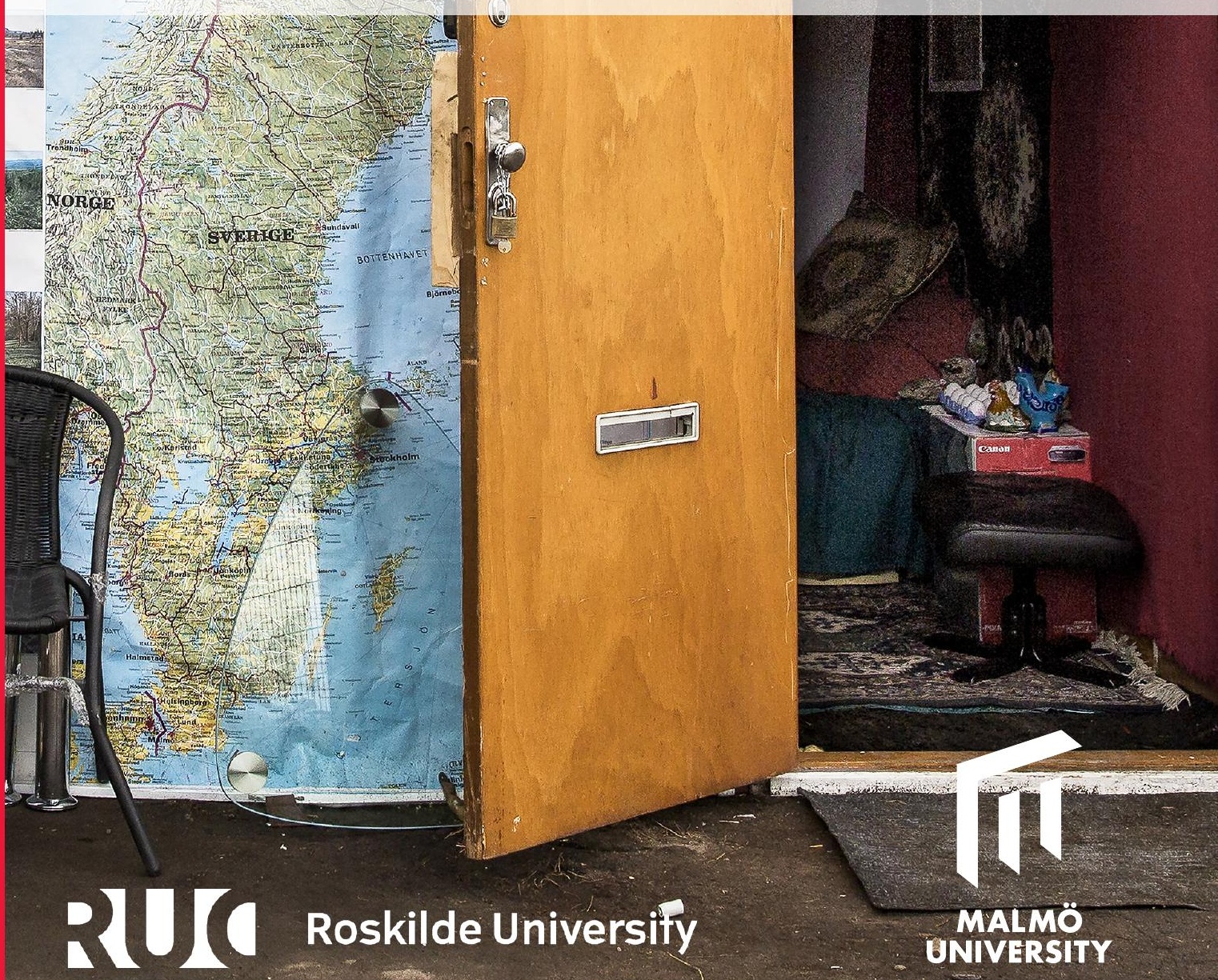



FREE TO MOVE ALONG 


\section{$\mathrm{PhD}$ Dissertation}

$\mathrm{PhD}$ programme in Society, Space and Technology, Department of People and Technology Roskilde University, Denmark

and

PhD programme in Urban Studies, Department of Urban Studies, Malmö University, Sweden

Dissertation series in Migration, Urbanisation, and Societal Change, publication no. 8, Malmö University. 


\section{MARIA PERSDOTTER FREE TO MOVE ALONG}

On the Urbanisation of Cross-Border Mobility Controls - A Case of Roma 'EU migrants' in Malmö, Sweden

Malmö University Migration, Urbanisation and Societal Change Roskilde University Society, Space, Technology 
Dissertation series in Migration, Urbanisation, and Societal Change, publication no. 8, Malmö University.

Previous publications in dissertation series

1. Henrik Emilsson, Paper Planes: Labour Migration, Integration Policy and the State, 2016.

2. Inge Dahlstedt, Swedish Match? Education, Migration and Labour Market Integration in Sweden, 2017.

3. Claudia Fonseca Alfaro, The Land of the Magical Maya: Colonial Legacies, Urbanization, and the Unfolding of Global Capitalism, 2018.

4. Malin Mc Glinn, Translating Neoliberalism. The European Social Fund and the Governing of Unemployment and Social Exclusion in Malmö, Sweden, 2018.

5. Martin Grander, For the Benefit of Everyone? Explaining the Significance of Swedish Public Housing for Urban Housing Inequality, 2018.

6. Rebecka Cowen Forssell, Cyberbullying: Transformation of Working Life and its Boundaries, 2019.

7. Christina Hansen, Solidarity in Diversity: Activism as a Pathway of Migrant Emplacement in Malmö, 2019.

8. Maria Persdotter, Free to Move Along: On The Urbanisation of Cross-border Mobility Controls - A Case of Roma 'EU migrants' in Malmö, Sweden, 2019.

The publication is also available electronically, see muep.mau.se 
Till min pappa, Per Gunnar Persson 



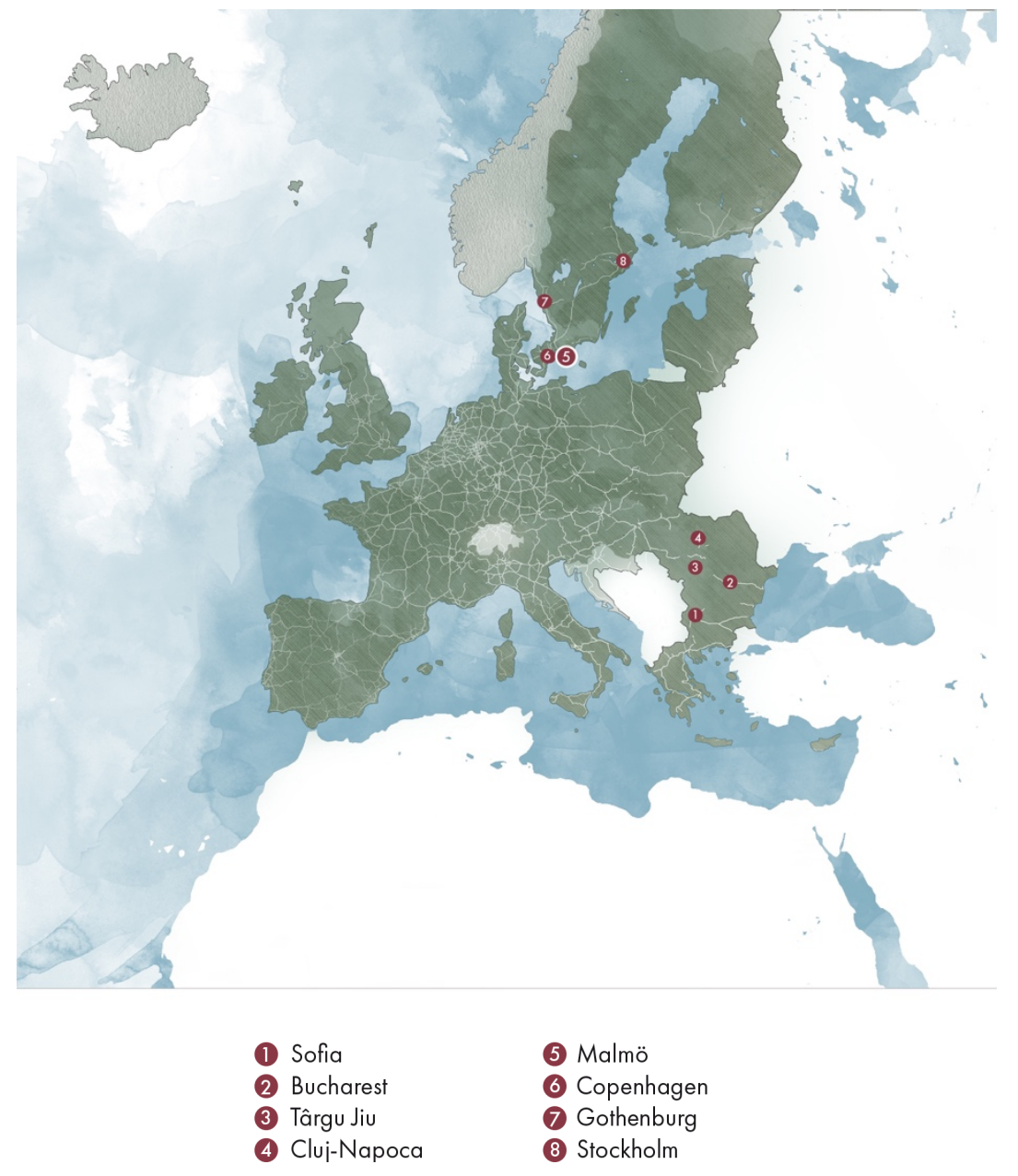

Figure 1: Map of Europe. Design: Nina Iglesias Söderström 


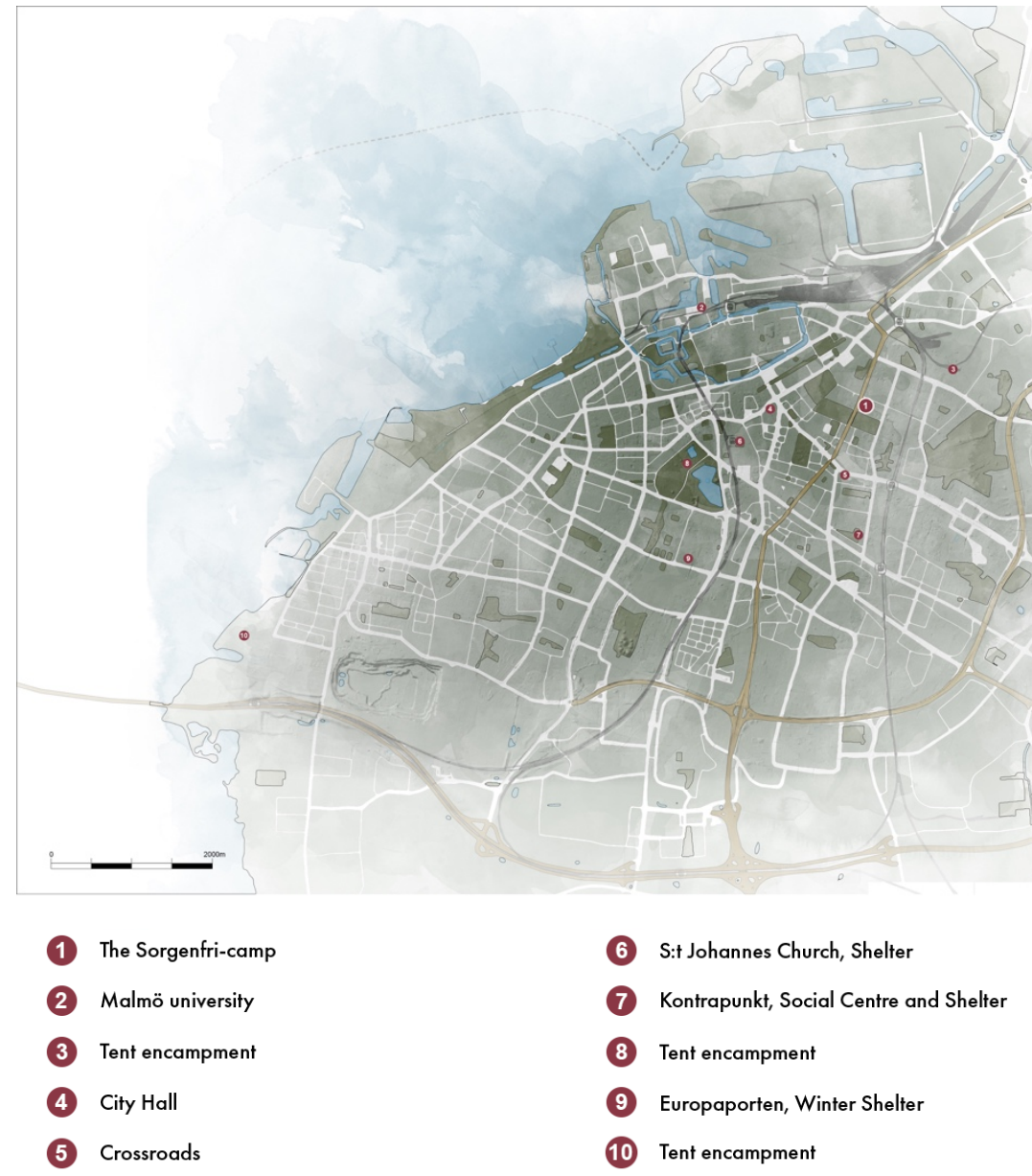

Figure 2: Map of Malmö. Design: Nina Iglesias Söderström. 


\section{CONTENTS}

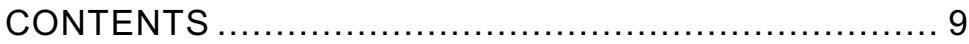

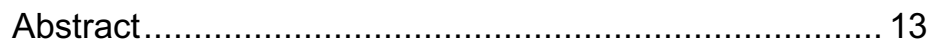

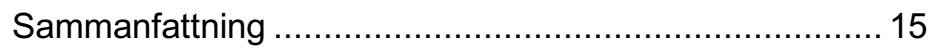

ACKNOWLEDGEMENTS ................................ 17

1. INTRODUCTION ...................................... 24

Purpose and Research Questions.................................. 29

Connections and Contributions to Previous Research ..... 30

Research Design and Delimitations ................................. 35

Background ............................................................ 38

Who Are the 'Vulnerable EU Citizens'? ...................... 38

EU Citizenship and Freedom of Movement ................ 45

Key National Policy Developments 2014-2016 .......... 50

Chapter Outline …….............................................. 53

2. STUDYING GOVERNMENT IN PRACTICE ........... 55

'Studying Up': Motivations and Starting Points ................ 55

Refuting Stereotypes? .......................................... 61

Brief Reflections on Activism and Research ...............65

Conceptualising Mobility Control and Government ..........66 66

Governmentality as a Toolkit for Political Analysis ......67

Research Design and Methods of Data Collection............75

Case Study: The Sorgenfri Camp............................... 76

Empirical Material and Methods of Data Collection..... 78

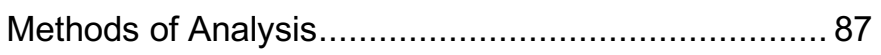

3. THE URBANISATION OF MOBILITY CONTROLS .. 90

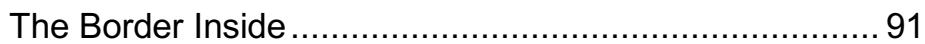

Theories of Scale and Re-scaling ….............................. 96 
Games of Scale and Jurisdiction 99

The Urban as a Scale of Mobility Control ................. 101

Urban Mobility Controls in an Historical Perspective...... 107

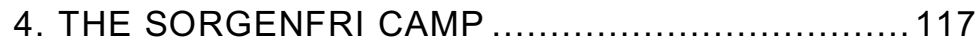

An Introduction to the Case ........................................ 117

A Space of Destitution, a Space of Defiance ................. 122

'A Major Nuisance in Our Backyard'............................. 128

'Don't Throw Us Out Like Trash' .................................. 130

5. EVICTED, BECAUSE EVERYONE SHOULD HAVE ACCESS TO GOOD HOUSING .......................... 136

The Symbolic Meaning of Dirt ................................... 138

Nuisance Complaints................................................ 142

'Should We Accept This Standard of Living?' ................ 152

Concluding Remarks ................................................ 159

6. LEGALLY REDUCED TO LITTER ..................... 162

Not an Eviction ....................................................... 163

Law and Legal Technicalities ...................................... 165

Attempts by the Property Owner to Evict the Squatters . 169

Attempts by the Municipal Authorities to Address a

'Nuisance Problem' ...................................................... 173

Addressing Illegibility .................................................. 181

Features and Effects of Nuisance Government ............ 187

Regulating Space, Deflecting Rights ........................... 194

Concluding Remarks ............................................. 200

7. UNDOING THE GEOGRAPHIES OF SURVIVAL ...203

Entry Point: A One-Way Bus Ticket Back to Romania ... 204 Negotiating Residency and Rights in the Municipality 208

'The Principle of Ultimate Responsibility' and the Ambiguity of the Categories of Residency ................ 212

At the Threshold of the Threshold ............................. 215 
A Dual Approach: Local Initiatives and Policy

Developments in Malmö, 2014-2016

The 2014 Report 'Socially Vulnerable EU Citizens in

Malmö - Their Situations and Needs'

223

Steps Towards a Coordinated Policy.

227

The Municipal Strategy on Unauthorised Settlements

230

Local Policies and Initiatives to Provide Shelter and Services 232

Undoing the Geographies of Survival ........................... 235

Concluding Remarks 238

8. FREE TO MOVE ALONG 240

'EU Citizens Are Welcome, but Swedish Legislation Will

Apply' 242

Mechanisms and Implications of Control 246

Conceptualising the Urbanisation of Mobility Controls 251

Suggestions for Further Research........................... 253

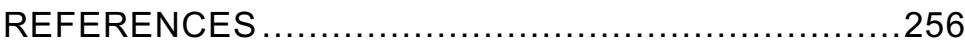

APPENDIX: "READING GUIDE" .........................288 



\section{Abstract}

This thesis traces the local government response to the presence of impoverished and street-homeless so-called vulnerable EU-citizens in Malmö (Sweden's third largest city) between the years 2014-2016, and develops an analysis about how bordering takes place in cities.

"Vulnerable EU-citizens" is an established term in the Swedish context, used by the authorities to refer to citizens of other EU Member States who are staying in Sweden without a right of residence and in situations of extreme poverty and marginality. A majority of those whom are categorised as "vulnerable EU-citizens" are Roma from Bulgaria or Romania.

Starting from the observation that "vulnerable EU-citizens" have been pervasively problematised as unwanted migrants, the thesis asks how the municipal- and local authorities in Malmö act to discourage and otherwise manage their mobilities by controlling their conditions of stay. In doing so, it seeks to elaborate on theories about intra-EU bordering practices, and to elucidate some of the mechanisms, effects and implications of urban mobility control practices.

Methodologically, the thesis is structured as a case study, centring on the case of the intensely contested Sorgenfri-camp - a makeshift squatter settlement that housed a large proportion of Malmö's estimated total population of "vulnerable EU-citizens". The Sorgenfri-camp was established in 2014 and lasted for a year and a half before it was demolished in November 2015 on the order of the City of Malmö's environmental authorities. Often referred to in the media as "Sweden's largest slum", the Sorgenfri-camp was quite literally a central locus of a local and national political "crisis" regarding the growth of unauthorised squatter settlements. As a "critical case", it offers a vantage point from which to trace the development of policy and government practices towards "vulnerable EU-citizens" and observe how the authorities negotiate the legal ambiguities, moral-political dilemmas, and social conflicts that swirl around the unauthorised settlements of "vulnerable EU-citizens". It also serves as a key example of a more widespread 
framing of "the problem of vulnerable EU-citizens" as an order, nuisance and sanitation problem.

The analysis is carried out with a theoretical framework informed by Foucaultian poststructuralist theory and theories of scale, combining insights from the field of critical border and migration studies with concepts from the legal geographic literature on urban socio-spatial control. In particular, it follows socio-legal scholar Mariana Valverde's (2010) call to foreground the role of scalar categorisation and politics in the networked policing of various non-citizens. The analysis addresses the construction of the Sorgenfri-camp and its residents as a "nuisance problem" in popular and policy discourse, and explores the effects and consequences of this framing in the context of the administrative-legal process that resulted in the demolition of the settlement.

The thesis highlights the city as a space where complex negotiations over residency-status, rights and belonging play out. It submits that local authorities in Malmö have responded to the presence and situation of vulnerable EU-citizens in the city by enacting a series of practices and programs that jointly add up to an indirect policy of exclusionary mobility control, the cumulative effect of which is to eliminate the "geographies of survival" for the group in question. Furthermore, it argues that this reinforces the complex modulations of un/free mobility" in the EU: destitute EU-citizens who are formally free to move and reside within the union are repeatedly moved along, and thus effectively prevented from settling. This is taken to be illustrative of an urbanisation of mobility control practices: a convergence between mobility control and urban socio-spatial control, or a rescaling of mobility control from the edges of the nation-state to the urban scale and, ultimately, to the body of the "vulnerable EU-citizen". 


\section{Sammanfattning}

Den här avhandlingen - som jag valt att ge den svenska titeln Fri att röra sig, förvisad att röra sig: Rörlighetskontrollens urbanisering - Fallet med romska EU-medborgare i Malmö - behandlar den lokala politik som utvecklades i Malmö under åren 2014-2016 i förhållande till närvaron av så kallade utsatta EU-medborgare, och utvecklar ett teoretiskt resonemang om hur exkluderande gränser tar plats och blir till i städer.

"Utsatta EU-medborgare" är ett begrepp som används av svenska myndigheter för att beteckna medborgare från andra EU länder som vistas i Sverige utan en fast uppehållsrätt och som befinner sig i situationer präglade av extrem fattigdom och marginalisering. Medparten av dem som klassas som "utsatta EU-medborgare" är romer med ursprung i Bulgarien eller Rumänien. I avhandlingen konstateras att gruppen i den allmänna debatten i mycket hög utsträckning omskrivs som oönskade migranter. Med detta som utgångspunkt ställs således frågan hur kommunala och andra lokala myndigheter i Malmö agerar för att hantera närvaron av "utsatta EU-medborgare", och hur detta i sin tur påverkar deras möjligheter att utöva sin "fria rörlighet". Avhandlingen gör en ansats att utveckla ett teoretiskt resonemang kring urbana gränspraktiker inom EU. Särskilt undersöks de mekanismer som utgör grunden för urban rörlighetskontroll: hur de fungerar, vilka effekter de medför och vad detta i sin tur innebär för den som blir måltavla för sådana praktiker.

Avhandlingen är uppbyggd kring en fallstudie av konflikterna kring det så kallade Sorgenfri-lägret - en provisoriskt byggd bosättning som utgjorde ett hem för en stor andel av Malmös "utsatta EU-medborgare" under åren 2014-2015. Sorgenfri-lägret revs efter en invecklad och mycket omtvistad process genom ett beslut i Malmö stads miljönämnd. Dessförinnan kom bosättningen som omnämnts som "Sveriges största slum" att stå i centrum för heta politiska debatter gällande frågan om olovliga bosättningar. Med utgångspunkt i fallet med Sorgenfri-lägret undersöker avhandlingen hur myndigheterna i och bortom Malmö resonerar kring och agerar i förhållande till de juridiska gråzoner, moraliska-politiska dilemman och sociala konflikter som omgärdar just 
denna fråga. Särskilt behandlas fallet med Sorgenfri-lägret som ett nyckel-exempel på hur "utsatta EU-medborgare" och deras bosättningar framställs och hanteras som en sanitär olägenhet och görs till föremål för ordningspolitiska insatser.

Analysen präglas av en poststrukturalistisk ansats och för samman två huvudsakliga forskningsfält: kritiska migrations-studier och rättsgeografisk forskning kring social och rumslig kontroll. Därtill utgör teorier om det som inom forskningen kallas för skalpolitik en viktig referenspunkt. Analysen behandlar den diskursiva framställningen av Sorgenfrilägret de som bodde där som en sanitär olägenhet och undersöker vilka effekter denna framställning fick för den juridiska process som i slutändan ledde till att lägret utrymdes och revs.

Avhandlingen som helhet pekar på staden som en arena där komplexa förhandlingar kring uppehållsrättslig status, rättigheter och tillhörighet utspelar sig. Ett bärande argument är att lokala myndigheter i Malmö har kommit att hantera frågan om "utsatta EU-medborgare" på ett sätt som sammantaget kraftigt inskränker gruppens tillgång till stadens rum, och som därför kan beskrivas som en slags exkluderande gränspolitik på den urbana skalnivån. Detta bidrar i sin tur (i praktiken) till att omforma och inskränka villkoren för den fria rörligheten. 


\section{ACKNOWLEDGEMENTS}

This dissertation has been a long time in the making. I started my $\mathrm{PhD}$ studies in early 2015 , but even before this I was thinking about many of the questions that came to animate this project. The dissertation is informed by the struggles and organic intellectual work of social justice activists on both sides of the North Atlantic and beyond, as well as by countless conversations that I have had with comrades and friends over the years. I cannot thank you all by name but I would like to acknowledge some of the people who have supported me, in various ways, over the last several years.

This dissertation would have never come to completion without the ongoing guidance and steadfast support of my four supervisors. Carina Listerborn - I consider myself incredibly lucky to have had you as my main supervisor. You are a model of intellectually curiosity and - above all - generosity. I have learnt a lot from your no-nonsense approach to research. Thank you for putting so much faith in me, and for allowing me the autonomy necessary to come into my own as a researcher. Lina Olsson - I have benefitted from your thoughtful readings and incisive comments on innumerable versions of this text. I am also grateful for our many conversations about the more personal aspects of academic life. Thank you for being available to offer guidance and support even (and especially) when I have been too proud to ask for it. Kristine Juul - I have felt your support throughout these years. Thank you for encouraging me to clarify my ideas, and for your repeated reminders to prioritise empirically grounded analysis over abstract theorising. Kirsten Simonsen - thank you for sharing your impressive knowledge of critical theory and for your excellent company on conference trips throughout the years. 
My most sincere gratitude also goes to the scholars who so generously agreed to be discussants and readers at my (many!) milestone seminars: Ingrid Sahlin, Diana Mulinari, Mustafa Dikeç, Jonas Alwall, Anna Lundberg, Mikael Spång, Norma Montesino, Per-Markku Ristilammi, Erica Righard, Gunnhildur Lily Magnusdottir, and - last, but certainly not least - Isabella Clough Marinaro. Your comments and suggestions significantly improved my thinking and writing. I am especially grateful to you, Isabella, for making my final seminar such a positive experience!

Anna Lundberg also deserves a special mention. Thank you, Anna, for taking an interest in my project and for acting as an "extra supervisor" during these years. Your passionate commitment to socially engaged scholarship and migrant justice struggles is inspiring! Special thanks also to Claudia Fonseca Alfaro who provided comments on what eventually became chapter 2, and to Ebba Hårsmar and Mirjam Katzin who gave advice on the analysis in chapters 6 and 7, respectively. Jasmin Salih expertly copy-edited the entire manuscript and fixed my many punctuation errors. Thank you for this! (That said, any remaining errors are my own and I take full responsibility for them.)

Jenny Eliasson, photographer at Malmö Museums, documented many of the events discussed in the thesis. Thank you, Jenny, for allowing me to use some of your images, including the one on the cover. Thank you also to Nina Iglesias Söderström who made the maps and graphics found in the thesis - it was a real pleasure working with you!

My PhD studies were largely funded by Critical Urban Sustainability Hub (CRUSH) - a FORMAS Strong Research Environment. Between 2014 and 2019, CRUSH brought together researchers from five different universities to critically engage with various aspects of the ongoing Swedish housing crisis. I will forever be grateful for the opportunity to be part of this exciting collaboration. A big thank you to Guy Baeten and Carina Listerborn who made it all happen, and to Brett Christophers, Henrik Gutzon Larsen, Karin Grundström, Ståle Holgersen, Mattias Kärrholm, Anders Lund Hansen, Irene Molina, Vítor Peiteado Fernández, Emil Pull, Ann Rodenstedt, Ove Sernhede, Catharina Thörn, and Sara 
Westin who took part in this rabble rousing, myth busting enterprise. A special thanks to Henrik who encouraged me to pursue a $\mathrm{PhD}$ and suggested that I apply to be part of the CRUSH environment, and to Irene for being my \#1 academic role model! Thanks also to Margit Mayer, Andrea Mubi Brighenti, Loretta Lees, Eric Swyngedouw, Tom Slater and Lawrence Berg who made up the CRUSH International Advisory Board, and who generously provided comments on my project at various stages of the process.

As a PhD student, I have split my time between Malmö University and Roskilde University. I would like to thank everyone in the Migration-, Urbanisation-, and Societal Change (MUSA) program at Malmö University for sharing the joys and frustrations of $\mathrm{PhD}$ life. Special thanks to Claudia Fonseca Alfaro and Mikaela Herbert for always being there to lend a listening ear, and to Jacob Lind for being such a superb co-author and friend! Vítor Peiteado Fernández and Emil Pull, my peers in the CRUSH group, have a special place in my heart: we started our $\mathrm{PhD}$ studies together on an icy day in February, 2015 and have followed each other side-by-side through the program. I am rooting for you both to finish soon! Thanks also to Ragnhild Claesson, Rebecka Cowen Forssell, Sabina Jallow, Malin Mc Glinn, Martin Grander, Christina Hansen, Zahra Hamidi, Ingrid Jerve Ramsøy, Charlotte Petersson, Ioanna Tsoni, and Roger Westin. I am glad I got to share this experience with you! I am also grateful for the friendship of several other colleagues at Malmö University: Pål Brunnström, Marwa Dabaieh, Anne-Charlotte Ek, Defne Kadioglu, Christina Lindkvist, Lorena Melgaço Silva Marques, Paula Mulinari, Vanna Nordling, Robert Nilsson Mohammadi, Camilla Safrankova, Hoai Anh Tran, Chiara Vitrano, Stig Westerdahl, and Klara Öberg. Here, I would also like to acknowledge Eric Snodgrass and Mahmoud Keshavarz. Furthermore, I wish to thank David Pinder, Tatiana Fogelman, Lasse Martin Koefoed, and Thomas Theis Nielsen for the exciting teaching opportunities you offered me at RUC. Special thanks to Tatiana for acting as a mentor - without your guidance I would have been lost! 
I have had a lot of help from the administrative staff at both Malmö University and Roskilde University. Kerstin Björkander, Malin Idvall, Roswitha Herslow and Sussi Lundborg at MAU, and Mikael David Meldstad at RUC each deserve a special mention. Thank you for being available to answer my many, many questions throughout the years! Thank you also to Hans Jonsson at MAU for providing legal advice and support, going above and beyond the requirements of your job to help me access various public records.

A heartfelt thank you also goes to my extended community of critical geographers and migration scholars: Noura Alkhalili, Özlem Çelik, Laleh Foroughanfar, Ståle Holgersen, Sofi Jansson-Keshavarz, Erik Jönsson, Marta Kolankiewicz, Annika Lindberg, Amin Parsa, Johan Pries, Maja Sager, Srilata Sircar, and Emma Söderman. As well, I would like to acknowledge my "true colleagues" - Hanna Bäckström, Erik Hansson, and Joshua Levy - who are (or have been) working on $\mathrm{PhD}$ projects closely related to my own. My analysis is indebted to your insightful work. Thank you for our conversations over the years! Martin Ericsson your ideas and suggestions have contributed in significant ways to this project. Thank you for your guidance and support! Thank you also to Jennie Gustafsson for your friendship, and to Malin Arvidsson for your thoughtful advice on how to cope with (and resist!) the many stresses of being a PhD student.

I am grateful to have Doktorandinnorna - Susanna Areschoug, Hanna Bornäs and Lovisa Häckner Posse - in my life. Tack för att ni satt guldkant på mitt sista år som doktorand!

In 2016, I spent a semester as a visiting student at my alma mater, Simon Fraser University (unceded Coast Salish territories/Vancouver). My stay was made possible by stipends from the Swedish Society for Anthropology and Geography (SSAG) and Stiftelsen för främjandet av Malmö högskolas utveckling. A big thank you to Nicholas (Nick) Blomley who generously agreed to be my academic host at SFU. Nick your distinct style of analysis and your witty way with words have made a strong impression on me and influenced how I think and write. You 
might notice some Blomleyisms between these pages. A shout out to my fellow students in the legal geography graduate seminar - Jennifer Chutter, Zool K. Suleman, and Mathias Vallentin Whede - and to the participants in the Feminist Geographies Reading Group at UBC. I learnt a lot from our discussions! A big thank you also to Geoff Mann. From the time I first set foot in your office, almost ten years ago, you have taken my ideas seriously, always treating me as an intellectual equal. Thank you for many stimulating conversations over the years and for your continuous encouragement.

The Vancouver housing market is a real nightmare. As a consequence of this, I moved four times during my brief stay in the city. Thank you to Angela Essak for your friendship and for hosting me at the good ol' New West Housing Co-op, and to Chashma Heinz for allowing me to stay in your beautiful nest by the train tracks - it was extremely noisy, but oh was the view of the Burrard Inlet worth it! A big thank you also to Sîn Madoc-Jones - my friend and twice roommate - for inviting me to stay with you and your sweet cat, Peanut. Spending a semester at SFU meant I got to reconnect with some of my old friends: Mordecai Briemberg, Jen Gibson, Isaac K. Oommen Shappil, and Cassie Sutherland. You each have a special place in my heart! I am also grateful for the friendship of Mikael Omstedt and Linda Lapina, who I got to know in Vancouver. Linda thank you for making me see the city anew, for always carrying a snack with you, and for your continuous support over the years. My dearest Heidi Pridy - words cannot express how much our friendship means to me. Thank you for coming up with the clever main title for this thesis, and for being such a stellar human being. I love you!

In 2018, I had the opportunity to spend a month with Isabella Clough Marinaro at John Cabot Univeristy in Rome. This was absolutely crucial to move the project forward. Isabella - thank you again for so generously sharing your time and knowledge. I am so glad I reached out to you! Mille grazie a Tiziana Constatino e Roberto Iossa per avermi ospitato durante il mio soggiorno e per avermi sempre fatto sentire la benvenuta a Roma. 
Some words for my close friends who have shown me so much love and patience over the years, putting up with my absent-mindedness and occasional grumpiness. Ali Kabir Zafari - I promised you I would put your name in the book. Thanks for your friendship, and for being such a good person to talk to. Also: Multumesc familiei Lacatus, în special Bella și Blaziana. Lina Lejfjord, Martin Bollerup Hansen, and Sigrid Törnqvist - thank you for the years we lived together in Kirseberg, for dejlig mush and busenissar, and for your continued friendship. Red Samaniego, dearest friend - even though we have drifted apart over the last years I continue to think of our friendship as one of the most important ones in my life. To the rest of my W3H10 posse - Mia Eskelund Pedersen, Siri Nanz Snow and Rashi Sabherwal - thank you for sharing the ups and downs of life (more recently via the "Amor" text-message group) and for always measuring these in love. Swathi Nirmal - thank you for everything we have shared over the years. Jonas Danielsson, Tove Rhodin, Tilde Wengelin and Anders Wengelin - thank you for welcoming me into your friend group when I first moved to Malmö six years ago, and for instantly making me feel at home. Somehow the four of you together managed to make six tiny human beings in roughly the same amount of time that it took me to make this one book. Your friendship - along with your kids' enthusiasm for playing hide-and-seek - got me through many rough patches. Tack, tack, tack!

And then there is Mirjam Katzin - my closest friend during these years. Tack, Mirjam, för att du funnits nära med en osviklig analytisk förmåga och ett empatiskt lyssnande öra. A special thank you to you for getting me across the finish line. What would I have done without you?

Andrea Iossa, mitt hjärtas fröjd. The great poet Ramazzotti says it best: grazie di esistere. Besides being the most wonderful partner in life and love, you also helped me in a big way to complete this thesis. Much of the thinking - and much of the suffering - that went into it was yours. Thank you for our many conversations about the intersections of law and geography, and for sharing your vast knowledge of all things EU related. In our team of two, you are the one in charge of fun - an assignment you take very seriously. Without you, my life would for sure be a lot duller. I 
am grateful to you for all the times you dragged me away from my work. Keep doing so! You are the joy of my life. Ti amo!

Finally, a big heartfelt thank you to my entire family, my home: $\min$ mamma Eva-Karin Nilsdotter, min pappa Per Gunnar Persson, my brother Jens Persson, and everyone else I know and love in and around Särdal and Steninge. Having moved away as a teenager and spent almost a decade living abroad, I can say this: borta bra, men ni är bäst! A special mention to my cousin Lisa Larsdotter Nilsson, who is also my close friend and self-appointed PT at Friskis \& Svettis. Thank you for EVERYTHING! Most of all, thank you for our ongoing conversation about creative work and for reminding me that my head is attached to a body - a body that needs to shake it out to a Eurovision Song Contest hit at jympa medel once in a while.

I dedicate this thesis to my father, Per Gunnar (Peppe) Persson, my biggest supporter since day one, who lovingly and patiently taught me to think critically. Tack för allt du är och allt du lär mig!

Saint-Gilles, Brussels, October 15, 2019 


\section{INTRODUCTION}

This thesis explores the urbanisation of mobility controls and bordering practices towards destitute so-called vulnerable EU citizens ( $\mathrm{Sw}$ : utsatta EU-medborgare) through a case study from Malmö, Sweden. ${ }^{1}$

The year 2014 was a critical one for political responses to the presence of 'vulnerable EU citizen' in Sweden. In the weeks leading up to the European Parliament Election on May 22-25, the nationalist party, the Sweden Democrats (Sverigedemokraterna), filled the Stockholm metro system with campaign posters that exclaimed in bold block letters 'IT IS TIME TO STOP THE ORGANISED BEGGARY IN OUR STREETS', NO MORE EU BEGGARY IN SWEDEN'. ${ }^{2}$ The campaign seized on a growing moral panic about the visible presence of impoverished and often homeless EU citizens on the streets (Cohen, 1987; Hall, Critcher, Jefferson, Clarke, \& Roberts, 1978). And it worked. Although the campaign was divisive and many were appalled by their message, the Sweden Democrats succeeded in making the question of EU beggary one of the decisive issues, not just of the European Parliament election, but of the entire super-election year. The May election of 2014 saw the Sweden Democrats enter into the European Parliament for the first time in history. In the September national elections, they more than doubled their support

\footnotetext{
${ }^{1}$ The term 'vulnerable EU citizen' is an established one in the Swedish context. It is used by government authorities to refer to citizens of other EU member states who are staying in Sweden in situations of extreme poverty and marginality. I will provide a more detailed defintion and discussion of the term in the section titled 'Who are the "Vulnerable EU citizens"?'

${ }^{2}$ Unless otherwise stated, all translations from Swedish into English are my own. For technical administrative and legal terms, I have used the 2011 edition of Svensk-engelsk ordbok för kommuner och landsting [SwedishEnglish dictionary for municipalities and regional governments], issued by the Swedish Association of Local Authorities and Regions (SALAR) and the $4^{\text {th }}$ and $5^{\text {th }}$ editions of the Swedish/English Glossary for the Courts of Sweden.
} 
(from 5.7 to 12.86 per cent). This gave the party a strategically important role as a powerbroker between the relatively weak red-green coalition government and the right-wing opposition, which in turn served to ensure that questions of immigration would be at the centre of Swedish parliamentary politics and public debate for the next several years (cf. Schierup, Ålund, \& Neergaard, 2018).

The success of the Sweden Democrats' campaign was paralleled by a measurable increase in the number of hate-crimes and other forms of subjective violence against 'EU migrants' (Sw: EU-migranter), who are pervasively although often implicitly racialised as Roma (Quensel \& Vergara, 2014). There are also indications that the antipathy towards EU migrants spilled over onto resident Roma and Travellers (see discussion in Wallengren \& Mellgren, 2015, 2017b). The Swedish National Council for Crime Prevention (BRA) noted a total of 290 reported hate crimes with anti-Roma motives in 2014 - the highest number to have been recorded up to that point (Brottsförebyggande rådet, 2015, pp. 66-72).

Just one day after the national elections, on September 15, Vasile Zamfir died in a hospital bed in Stockholm. Zamfir was a 41-year-old father of two, a Romanian citizen, and a self-identified Roma who sustained severe burn-injuries when a fire broke out in the tent encampment in Högdalen, south of Stockholm, where he was staying with his wife and friends. To this day, it remains unknown whether Zamfir was the victim of a tragic accident or his tent had been deliberately set on fire. The police neglected to carry out the requisite forensic examinations in a timely manner, instead waiting over seven hours before cordoning off the site. As a result, evidence of a potential case of arson was lost. However, following the incident, it was revealed that vigilante groups had disseminated detailed information, including maps and photographs of 'Roma camps', on the social media forum Flashback and threatened to 'burn the shit down'. Zamfir's widow also told news reporters that she and her husband had been attacked with rocks and had their tyres slashed in the weeks prior to the fire (Fekete, 2014; Habul, 2014). 
Meanwhile in Malmö, the Environmental Administration ( $\mathrm{Sw}$ : Miljöförvaltningen) was receiving a steady stream of nuisance complaints about a settlement ( $\mathrm{Sw}$ : boplats) on a vacant lot located at the intersection of Industrigatan and Nobelvägen in the Sorgenfri neighbourhood. The brownfield site has been a hideout for rough sleepers for many years, and squatters have typically been able to remain on the site for a couple of days, or sometimes weeks, before being moved on by the authorities (Knutagård, 2009). However, this group of occupants seemed determined to make a more permanent home for themselves on the lot. The majority of them came from Târgu Jiu, a city in southwestern Romania, and fit the common description of a 'vulnerable EU citizen': They had no formal employment and, therefore, no stable right of residence in Sweden. Consequently, they had extremely limited rights to social assistance and services and practically no access to publicly sponsored shelters. By most standards, the weed-covered vacant lot was not a good place to live. For one thing, it lacked electricity, sanitary facilities, and drinking water. It was also privately owned and slated to be redeveloped sometime in the not too distant future. Nevertheless, it was an alternative to the disorganised life on the streets. Over the course of the fall and early winter of 2014, more and more people moved into the settlement until eventually there were about 200 people living there. Some of the squatters constructed makeshift sheds for themselves, using building materials and woodstoves they had received as donations from a local solidarity network. Others purchased camper trailers to live in. By the end of the year, the settlement looked like an established tent village. In Malmö, it became known as the Sorgenfri camp ( $\mathrm{Sw}$ : Sorgenfri-lägret). In the news media, it was more often referred to as a 'migrant-' or 'Roma camp' or a 'shantytown' (Alveflo, 2014). Over time, it also acquired a reputation as 'Sweden's largest slum' (Karlsson, 2015).

As the largest and most visible settlement of 'vulnerable EU citizens' in Sweden, the Sorgenfri camp became an important reference point for the wider debates about the 'vulnerable EU citizens' question and the problem of homelessness among EU citizens. The controversies surrounding the Sorgenfri camp were also decisive for the development 
of government policy and practice at both the municipal and the national level. In early November, 2015, following a convoluted and intensely contested administrative and legal process, the Sorgenfri camp was demolished on the order of the City of Malmö's Environmental Committee. The squatters ended up on the street with minimal access to shelter, having had their pleas for an alternative, authorised campsite rejected by the municipal government. Some of them left town shortly thereafter, while others stayed on, determined to protest their treatment. Some of them staged a sleep-in protest outside Malmö City Hall, which went on for over two weeks and which received backing from several prominent Roma rights activists, including Member of the European Parliament, Soraya Post (Lauffs, 2015). The demolition of the settlement also attracted criticism from a number of human rights organisations, including the United Nations Special Rapporteur on minority issues, Rita Izsák, who expressed concern that that demolition would 'reinforce the exclusion and marginalized position' of the Roma evictees and 'have serious implications of the enjoyment of their fundamental human rights' (United Nations Human Rights Office of the High Commissioner, 2015, p. 3).

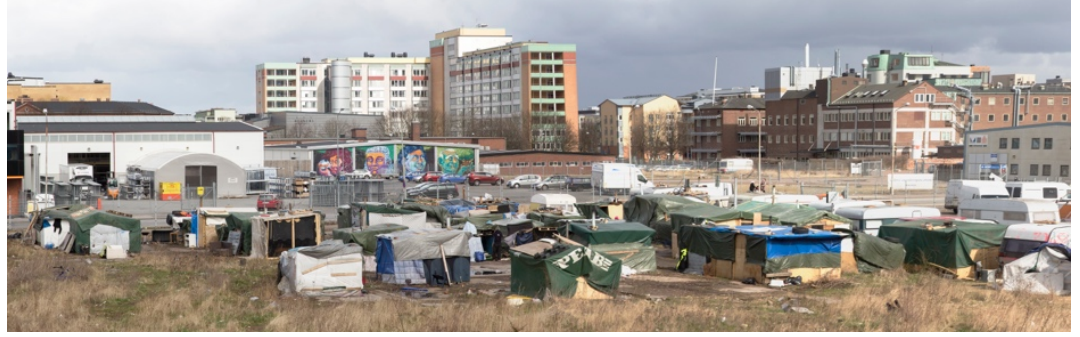

Figure 3. The Sorgenfri -camp (C) Jenny Eliasson / Malmo Museums

Significantly, these events took place against the backdrop of a growing social interest in the history of Roma and Travellers in Sweden, and a renewed commitment of part of the Swedish state to work towards the inclusion of Roma and Travellers (Kulturdepartementet, 2016). In March 
2014, the right-wing coalition government released a much-noted White Paper on state-sanctioned abuses and rights violations committed against Roma and Travellers during the long 1900s (DS 2014:8). The publication, which forms a part of the Swedish state's overall strategy for Roma inclusion, arguably marked an important moment of recognition for Roma and Travellers. Although the government declined to make a ceremonial apology, the then minister for integration, Erik Ullenhag, emphasised that he saw the White Paper itself as a form of redress and a decisive break with the long history of state racism towards Roma and Travellers (cited in Szoppe \& Gustafsson, 2014).

The first serious effort of the national government to address the situation of 'vulnerable EU citizens' came in early 2015, when they appointed the lawyer Martin Valfridsson as National Coordinator for Vulnerable EU Citizens. His main task was to examine the situation of the population in question and provide the relevant authorities, who were facing a number of thorny ethical and political dilemmas, with clear policy recommendations. Roughly a year after his appointment, in early 2016, the national coordinator released a report (SOU 2016:6), which has since guided policy and practice towards 'vulnerable EU citizens'. One of the report's key recommendations was a zero-tolerance approach towards unauthorised settlements.

Sweden's message should be clear. EU citizens are welcome here, but Swedish legislation will apply. Living in parks, other public spaces or on private land is prohibited. The same applies to littering and to relieving oneself in public. (SOU 2016:6, p. 15)

The quote serves as an example of how the mobilities of 'vulnerable EU citizens' are reformulated as a public order and sanitation issue. In a matter of three short sentences, it slides from affirming the abstract right to freedom of movement to declaring that open defecation will not be tolerated. As such, it reflects the meeting and meshing of mobility control policy and various forms of urban socio-spatial controls that are the central topic of this dissertation. 


\section{Purpose and Research Questions}

The thesis starts from the assumption that the presence of impoverished EU citizens who beg and live rough in Sweden presents a set of complex political challenges and dilemmas with bearings on several different policy areas including EU, housing, homelessness, migration, social, and urban policy. How have such seemingly disparate policy issues as transnational mobility rights and public space regulations been conjoined under the umbrella of a singular 'question' (i.e., the question of vulnerable EU citizens)? And how did it happen that this 'question' was framed mainly as a question of public order, sanitation, and... excrement?

The philosopher Étienne Balibar $(2002,2004)$ hypothesised more than 15 years ago that the project of European unification, and the enlargement of the free movement zone, would be paralleled by the emergence of a system of 'European Apartheid', based on the fortification of the external borders of the union and the reduplication of these in the form of internal ones. In a memorable turn of phrase, he concluded that under such conditions, the border would become 'dispersed a little everywhere, for example in cosmopolitan cities' (2004, p. 1). Elsewhere, Balibar (2009b) has also suggested that mobile Roma EU citizens have emerged as a crucial 'test case' for this hypothesis.

If Balibar is right, it would be important to explore how bordering takes place in cities, that is, how urban mobility controls are configured - what their mechanisms, effects, and implications are - and how they can be challenged. Crucially, these are questions that have not been fully addressed in the abundant literature on the re-spatialisation of borders. Although many have noted that the treatment of mobile Roma EU citizens in various national contexts amounts to a simultaneous internalisation and racialisation of the borders of Europe, few have called attention to the fact that it also frequently entails a simultaneous municipalisation and urbanisation of borders and mobility control practices (although see Fouteau, Fassin, Guichard, \& Windels, 2014).

Building on Balibar's notion of 'interior frontiers', this thesis considers how the City of Malmö has responded to the presence of impoverished 
and often homeless EU citizens. Methodologically, it is organised as a case study - centering on the case of the Sorgenfri camp, the conflicts surrounding it, and the intensely contested process that ultimately led to its demolition.

The purpose of this thesis is as follows:

To explore how the municipal and local authorities in Malmö act to discourage and otherwise manage the mobilities of 'vulnerable EU citizens', who have a right to move within the territory of the EU member states but whose mobilities are nevertheless deemed excessive and problematic.

This overarching research purpose translates into the following questions:

- How did the Sorgenfri camp come to be framed chiefly as an environmental and nuisance problem, and how did this framing shape the process that led to its demolition?

- How have the authorities negotiated the legal ambiguities as well as the moral-political dilemmas that arise in relation to the geographical presence of destitute EU citizens without a definitive right of residence?

- On the basis of the case study, how can we understand the mechanisms, effects, and implications of urbanised mobility controls?

\section{Connections and Contributions to Previous Research}

The thesis is intended as a contribution to three interrelated and overlapping research areas. First, the thesis engages with the scholarly discourse on the re-spatialisation of borders (Balibar, 2004, 2009a; Burridge, Gill, Kocher, \& Martin, 2017; see Darling, 2011, 2016; Sassen, 2013; Squire \& Darling, 2013; Varsanyi, 2006, 2010b, 2010a). In particular, it seeks to develop an empirically-based analysis and argument about the strategic re-scaling and urbanisation of mobility controls. In doing so, it draws on the legal geographic literature on urban spatial regulation to provide a more refined analysis of the mechanisms and 
implications of the process in question (Blomley, 2007b, 2011; Mitchell, 2007; Mitchell \& Heynen, 2009; Ranasinghe \& Valverde, 2006; Valverde, 2009, 2010, 2011).

Second, it engages with a strand of critical scholarship concerned with the governance and securitisation of Roma mobilities in present-day Europe and with the urban marginalisation and segregation of Roma communities (Aradau, 2015; Clough Marinaro, 2014a, 2015; Clough Marinaro \& Daniele, 2011; Picker, 2017; Picker, Greenfields, \& Smith, 2015; R. Powell \& Lever, 2017; Ryan Powell, 2013; Ryan Powell \& van Baar, 2019; Pusca, 2010; van Baar, 2015b, 2017b, 2017c). It follows the advice of van Baar (2017c) to 'de-nationalise the notion of borders' and to focus on the ways in which the exclusions of Roma from regular housing is continuous with 'bio-political bordering practices' operative at other scales. The thesis contributes to the research area in question by focusing on a region (i.e., Sweden/the Nordic countries) that so far has received little attention in the international literature (although see Barker, 2017; Ciulinaru, 2017; Hansson \& Mitchell, 2018; Johansen, 2016; Tervonen \& Enache, 2017). The thesis also develops an analysis of the negation and non-recognition of Roma identities and minority rights that marks the government of 'vulnerable EU citizens' in Malmö. Finally, the thesis adds to the literature on the securitisation of Roma mobilities by bringing attention to the problematisation of 'vulnerable EU citizens' as source of sanitation and public order issues.

Third, the thesis is intended as a contribution to research on the governance and politics of street-homelessness in the Swedish context. In particular, the thesis expands on existing research on the 'sanitisation' of entrepreneurial city spaces and the use of order ordinances and other 'soft policies of exclusion' to exclude the urban poor (Franzen, 2001; Franzén, Hertting, \& Thörn, 2016; Thörn, 2011). It builds and expands on Sahlin's $(1996,2004,2013)$ work on local-level bordering practices in the social government of homelessness, and it makes the case that it is necessary to 
foreground questions of citizenship to understand the contemporary politics of homelessness and housing in Sweden. ${ }^{3}$

\section{Previous and Ongoing Research related to 'Vulnerable EU citizens'}

Furthermore, the thesis also adds to a growing body of academic research on the situation and treatment of 'vulnerable EU citizens' in Sweden. When I began doing research for this thesis in early 2015, there were almost no published academic studies on the topic. However, over the past five years, a number of academic articles and $\mathrm{PhD}$ dissertations have been issued that address various dimensions of the "question of vulnerable EU citizens' and other related topics. There are also a number of ongoing research projects that closely parallel my own.

One strand of this emergent literature addresses societal reactions to the appearance of 'foreign beggars' and explores the affective-experiential and socio-psychological dimensions of majority 'Swedish' subjects' encounters with EU citizens who beg and sleep rough. For example, Parsberg's (2016) $\mathrm{PhD}$ dissertation in fine arts, How to Become a Successful Beggar in Sweden, uses images of begging as a starting point to investigate how differences and power asymmetries are negotiated in what she calls 'the social choreography of begging and giving'. Hansson and Jansson (2019) have similarly attempted a psychoanalytically inspired interpretation of the collective 'crisis in Swedish self-image' triggered by the appearance of 'vulnerable EU citizens' (see also Hansson, 2014, 2015). Hansson's (2019) PhD dissertation in human geography offers a comprehensive analysis of the evolving public and political discourse on the 'question of vulnerable EU citizens' in Sweden between 2014 and 2016. According to Hansson (2019), the presence of impoverished and homeless EU citizens exposes both the 'Real' (a Lacanian psychoanalytic term) conditions of the current capitalist social order and the fundamental contradiction at the heart of the Swedish welfare state. This, he argues, explains why the encounter with the EU

\footnotetext{
${ }^{3}$ I present a more detailed literature review in chapter three.
} 
citizen beggar elicits such anxious and polarised reactions among members of the Swedish majority society.

In a separate article, written together with Mitchell, Hansson analyses the policy response to the unauthorised settlements of 'vulnerable EU citizens', drawing on Giorgio Agamben's treatise on the 'sovereign exception' to theorise the denial of basic rights for impoverished and homeless EU citizens (Hansson \& Mitchell, 2018). Similar questions about the exclusionary character of the Swedish welfare state and the negation of the human rights of 'vulnerable EU citiziens' have been raised by Bäckström, Örestig, and Persson (2016); by Ciulinaru (2017); by Nygren and Nyhlén (2017); and by myself and Jacob Lind (Lind \& Persdotter, 2017). Altogether, these works provide a springboard for the present study.

Another key reference for this study is sociologist Vanessa Barker's (2017) analysis of the national government's 2015 policy package to 'combat vulnerability and beggary'. Barker (2017) argues that the approach set out in the reform package can be conceptualised as a form of benevolent violence: a policy of 'forced deprivation brought about by good intentions' (p. 132). According to Barker, the state's treatment of 'mobile Roma' (her terminology) is indicative of the rise of what she calls 'penal nationalism' - the use of penal powers to exclude various categories of migrants for the purpose of keeping the welfare state solvent for those on the inside (see also Barker, 2018).

Coming at the same questions but from a somewhat different perspective, political scientists Spehar, Hinnfors, and Bucken-Knapp (2017) analyse the lack of an effective policy response to the situation of 'vulnerable EU citizens' as a failure of multi-level governance. Based on interviews with policy practitioners, they show that actors at all levels of government (local, regional, national, and EU) attempt to shift responsibility for integrating 'vulnerable EU citizens' onto other levels. While the EU institutions view it as a national policy issue, the national government insists that it is a 'local matter' or a question for the EU to address. In this context, local governments have been left to respond in an ad hoc manner 
to issues that are difficult to ignore, such as rough sleeping. My own study extends this analysis to consider the scalar politics involved in the government of 'vulnerable EU citizens'. That is, rather than asking why multi-level governance fails and how it could be rectified, I seek to analyse how scalar shifts are strategically deployed to achieve certain ends and to understand the effects and implications of such shifts.

Taking a less state-centric approach, a number of scholars have considered the role of social movement actors in challenging the exclusionary treatment of 'vulnerable EU citizens' and articulating new forms of belonging and membership outside or against the dominant citizenship regime. For example, Mešić (2016) analyses how civil society groups and volunteers in a small town in northern Sweden mobilised support for a group of stranded Bulgarian Roma berry pickers, and how they amplified the berry pickers' claims for recognition and rights as EU citizens. Focusing specifically on the activism and organising that took place around the Sorgenfri camp, Morell (2018) explores the tension between 'pragmatic voluntarism' and 'subversive humanitarianism'. Hansen (2019) also takes the Sorgenfri camp as a case study of placebased solidarity activism. Hansen's work explores how activist groups in Malmö forge alliances across inequalities and lines of migration-related difference and how activism serves as a vehicle for migrant emplacement.

There are a number of popular non-fiction books that revolve around the life stories and experiences of EU citizens who beg and sleep rough in Sweden (e.g., Lagerlöf \& Freiholtz, 2017; Olausson \& Iosif, 2015; Oldberg, 2016; Roos, 2018b, 2018a). However, so far there has been relatively little academic research that takes the experiences of individuals and communities labelled as 'vulnerable EU citizens' as their research object. One notable exception is geographer Levy's (2016) MA thesis and ongoing ethnographic $\mathrm{PhD}$ research with homeless Romanian Roma communities in and around Stockholm. The Copenhagen-based anthropologist Ravnbøl $(2015,2018)$ has also explored the livelihood strategies of Romanian Roma 'beggars' and bottle collectors in the Øresund Region and their encounters with law and law enforcement. Finally, Wallengren and Mellgren's (2015, 2017b, 2017a) ongoing 
research investigates the exposure of 'vulnerable EU citizens' to various forms of hate crimes (see also Lacatus, 2015).

\section{Research Design and Delimitations}

At its core, the thesis is concerned with governmental practices or 'governance', used here as a catch-all term to refer to 'any strategy, tactic, process, procedure or programme for controlling, regulating, shaping, mastering or exercising authority over others' (Rose, 1999, p. 15). ${ }^{4}$ It is thus an attempt to 'study up', by which I mean 'studying the powerful, their institutions, policies and practices instead of focusing only on those whom the powerful govern' (Harding \& Norberg, 2005, p. 2011). My emphasis is on the policies and practices of municipal and state authorities as these play out in the city, and the empirical material consists of a mix of policy- and legal documents, interviews, and observations. The temporal scope of the study covers a period from the establishment of the Sorgenfri camp in the early spring of 2014 until about a year after its demolition. This time span, 2014-2016, roughly corresponds with a period of heightened public and political debate about the presence and situation of 'vulnerable EU citizens' nationally (see Hansson, 2019).

The choice to focus on the government of 'vulnerable EU citizens' and the policies and practices of state and municipal authorities means that the thesis does not explore the experiences of individuals who lived in the Sorgenfri camp or have been labelled as 'vulnerable EU citizens' to any greater extent. The thesis will not take you, as a reader, inside the Sorgenfri camp. It is not a study of the everyday life and internal

\footnotetext{
${ }^{4}$ In this thesis, I sometimes use the words 'governance' and 'government' interchangeably to refer to the act and practices of governing (see the Oxford Dictionary defintion of 'government' as the 'action or manner of controlling or regulating a state, organisation, or people'). Some scholars prefer to make an analytical distinction between the two terms, treating 'governance' as an action and 'government' as a set of institutions. This distinction might be helpful if the goal is to analyse the changing role of the state (as 'government') or transformations in how governing is done. In the academic 'governance discourse' (Chakrabarty \& Bhattacharya, 2008), it is common to speak of a qualitative transformation from government to governance the key idea being that the role of the government and public authorities is diminishing and that governance has become increasingly networked, involving multiple actors on both sides of the public-private divide. As this is not the focus of my study, I choose to use the terms in a more flexible manner.
} 
organisation of the settlement. Although it discusses the social consequences of certain decisions and events, it does not directly account for experiences and perceptions of the squatters of these events. Instead, it is a study of conflicts and events surrounding the settlement and their broader political significance .

Geographically, the study focuses on a single city - Malmö. Situated at the proverbial 'gateway to and from Europe', it is typically the first city of arrival in Sweden for migrants coming from continental Europe. Malmö is Sweden's third largest city, with roughly 310,000 inhabitants (SCB, 2019). Over the past two decades, the city has undergone a major structural transformation from an industrial city into an entrepreneurial 'knowledge city' (Holgersen, 2017; Mukhtar-Landgren, 2012; Pries, 2017). Despite concerted efforts of the Social Democratic-led City Council to attract a 'creative class' of high-income earners to bolster local tax revenues, the city is one of the poorest in Sweden (Lönnaeus, Fjellman, Magnusson, Frennesson, \& Cronqvist, 2016). It is also experiencing an ongoing crisis of housing-inequality (Listerborn, 2018). According to the City of Malmö's annual homelessness counts, the number of homeless individuals in the city has more than doubled in the last ten years from about 900 individuals in 2008 to about 3,300 in 2018 (Malmö stad, 2018, 'vulnerable EU citizens' not included). Those affected by homelessness are disproportionately of migrant and workingclass background.

A major destination for organised labour migration in the post-war years and a landing-pad for subsequent 'waves' of refugee-migrants, Malmö has a unique reputation in Sweden as an 'immigrant-dense' and 'multicultural' city. To some extent, the city embraces this identity. There is a slogan: 'Haur du sitt Malmö, haur du sitt varlden'. Spelled in thick dialect, it translates as 'if you have seen Malmö, you have seen the world', and it is used to market everything from city real estate to courses in

\footnotetext{
${ }^{5}$ The actual percentage of residents with 'foreign background' (about $46 \%$ in 2018) is similar to many municipalities in the Stockholm metropolitan area, like Botkyrka, Södertälje, and Sundbyberg (SCB, 2018).
} 
diversity management. At the same time, there is an explicitly racialised discourse that sees Malmö as a hotbed of organised crime and gang violence - 'Sweden's Chicago' - and that blames many social ills on the city's immigrant population (Schclarek Mulinari, 2015, 2017). Given the thesis focus on urban mobility control and bordering practices, it is worth noting that the municipal leadership in Malmö has lobbied (and continues to lobby) the national government to regulate asylum accommodation in such a way as to steer recently arrived refugee migrants away from the city (Ovesen, 2018). At the same time, the City of Malmö is also known for having had relatively inclusive policies towards undocumented migrants living in the city. For example, the municipality was one of the first in the country to formulate local policy guidelines on social assistance and services to this group (Lundberg \& Dahlquist, 2018; Nordling, 2012, 2017).

My choice to restrict the analysis to a single city stems from my interest in local- and urban-scale policy responses. However, this does not mean that I think of the city as a closed container. Quite the opposite. What happens locally in Malmö is connected to what happens at other geographical scales and in a myriad of other places: in the neighbouring town of Lund, in Göteborg and Stockholm, across the bridge in Copenhagen, in Brussels and Strasbourg, as well as in the Oletina and Transylvania regions of Romania, where many of the squatters of the Sorgenfri camp came from. My understanding of the city, and of 'place', comes close to Doreen Massey's (2005) concept of place as an 'evershifting constellation of trajectories' (p. 151). Importantly, I do not think of Malmö as representative of a country-wide or specifically Swedish approach to the question of 'vulnerable EU citizens'. It has been important to me to resist the view that the national is above and beyond the local and to avoid the common trap of treating the nation-state (in this case, Sweden) as a container of political processes and events. Indeed, the thesis as a whole might be read as an attempt to question the taken-forgrantedness of the nation-state in policy discourse as well as in much migration scholarship (see Wimmer \& Glick Schiller, 2002, for an influential critique of 'methdological nationalism'). 
As a direct consequence of my methodological choice to focus on the geographical and institutional context of the City of Malmö, I do not examine debates and policy developments concerning begging in any greater detail. I want to emphasise that this issue has indeed been a major focus of policy- and popular debates in the last several years. In fact, a clear example of what I will describe as the re-scaling of control policies has occurred in this area, where several municipalities have implemented (or are considering implementing) locally-based and site-specific antibegging ordinances, intentionally but indirectly targeted at EU citizens. However, the issue of begging has not featured particularly prominently in local debates, nor have there been any efforts to regulate begging locally.

\section{Background}

\section{Who Are the 'Vulnerable EU Citizens'?}

The term 'vulnerable EU citizen' (Sw: utsatta EU-medborgare) is an established term in the Swedish context, and it is used by the authorities to refer to citizens of other EU Member States who are staying in Sweden in situations of extreme poverty and marginality. The prefix, utsatta, literally translates as 'exposed', and it belongs together with words like 'social risk' and 'exclusion' (Sw: social risk och-utanförskap) in what some consider to be a distinctly neoliberal discourse on social problems and inequalities - one that obscures and depoliticises the structural factors behind problems like housing insecurity and poverty (Davidsson, 2015, pp. 17-19). It is not clear who first coined the term, but it was adopted by the Swedish government and authorities in connection with the appointment of the National Coordinator for Vulnerable EU Citizens, Martin Valfridsson, in early 2015 as an alternative to the widely used but disputed term 'EU migrants' (Ramel \& Szoppe, 2014). ${ }^{6}$ In news media, however, both terms ('EU migrants' and 'vulnerable EU citizens') are

\footnotetext{
${ }^{6}$ The term 'EU migrants' is seen by some to be problematic as it negates the EU citizenship and mobility rights of the individuals in question (see discussion in Chatty, 2015).
} 
used more or less interchangeably with terms like 'homeless EU citizens', 'foreign beggars', 'Roma beggars', or simply 'beggars'.

The exact definition of the term 'vulnerable EU citizens' varies. For example, the aforementioned report by the National Coordinator for Vulnerable EU Citizens strictly defines it as 'individuals who do not have a right of residence in Sweden' (SOU 2016:6, p. 13). However, already on the first page, the report makes it clear that it is really concerned with a much more narrowly defined subset of this broad, somewhat ambiguous status-category, namely those who 'beg and sleep rough in Swedish cities and towns' (SOU 2016: 6, p. 7). A second, more detailed definition, comes from a 2015 report of the National Police Authority:

Vulnerable EU citizens refers ... to citizens of another EU member state, who live in poverty and under conditions of social exclusion. Enabled by freedom of movement within the EU, they have come to Sweden to seek livelihoods, most often by begging in public spaces. They normally lack housing and means of subsistence in Sweden. They frequently also lack access legal livelihood strategies other than begging. The vulnerable EU citizens who are staying in Sweden are almost without exception from Bulgaria or Romania. (Polismyndigheten NOA, 2015, p. 7)

As there is no clear-cut definition of the term, it is technically impossible to know how many 'vulnerable EU citizens' there are in Sweden. Even with a reliable definition, it would be practically difficult to count: the border crossings of EU citizens are not systematically recorded, and street homelessness is notoriously difficult to measure. The estimates that do exists derive from interviews and questionnaires with service providers, and they give a rough picture of approximately how many destitute EU citizens come into regular contact with the public social services or with non-state service providers. According to the aforementioned report by the Swedish Police, there were about 4,700 'vulnerable EU citizens' in Sweden in 2015, including between 70 and 100 children (Polismyndigheten NOA, 2015; see also SOU 2016:6). That same year, the City of Malmö estimated that there were about 500-600 'vulnerable EU citizens' residing in the city, about half of whom lived in the Sorgenfri camp. Four years later, in 2019, there are still an estimated 4,500-5,000 
'vulnerable EU citizens' in the country as a whole (Mattsson, 2019), but in Malmö, the number has gone down to about 200 (Länsstyrelsen Skåne, 2018). ${ }^{7}$

It is important to keep in mind that the term 'vulnerable EU citizens' does not name an objectively existing group of people. Rather, it is the ongoing categorisation of 'vulnerable EU citizens' in law, policy, and public discourse - not to mention, in academic knowledge production - that brings the category into being. I take categorisation to be a fundamental, and perhaps unavoidable, feature of the practices of government. At the same time, I understand it as a performative practice, one that is entirely embedded in discourse. Categories do not simply name pre-existing entities, they help constitute the very entities they name (Butler, 1993, p. xii). A crucial dimension of this is the drawing of boundaries. Such boundaries do not simply re-inscribe already existing differences. Rather, they create the differences that they name: 'boundaries come first, then entities' (Abbott, 1995, p. 860). As such, the category of 'vulnerable EU citizens' is constituted at the intersection of discourses pertaining to freedom of movement, national citizenship, and minority rights protection. As a government category, it is a particularly ambiguous and unstable one. This is made evident by the fact that it constantly blurs into other categories. For example, it is not always so clear what exactly sets it apart from the overall category of 'mobile EU citizens'. It is also, as we will see, a category that seems to require constant definition and redefinition. For one thing, the Swedish authorities have found themselves hard at work trying to determine whether or not 'vulnerable EU citizens' should be entitled to certain rights that are codified in law as belonging to irregular migrants (Lind \& Persdotter, 2017). I am particularly interested in how boundaries are drawn between 'vulnerable EU citizens' and other mobile EU citizens to render the former as a kind of 'abject EU citizens'

\footnotetext{
${ }^{7}$ To contextualise these figures, there are over 3,000 homeless individuals in Malmö (vulnerable EU citizens not included) and about 33,000 in the country as a whole (Socialstyrelsen, 2017a). The number of undocumented migrants (Sw: papperlösa) is estimated to be somewhere between 20,000 and 50,000 .
} 
(Hepworth, 2012) whose mobilities are deemed excessive and problematic.

If the term 'vulnerable EU citizens' is useful as a shorthand to refer to a figure that circulates in policy and public discourse, I try to avoid using it to refer directly to actually existing people. I have yet to come across a single person who self-identifies as a 'vulnerable EU citizen' or an 'EU migrant'. Throughout the thesis, I use quotation marks around the term to emphasise that I think of it as a category, a label. I also use a different term to refer to the inhabitants of the Sorgenfri camp, namely 'squatters' (Sw: ockupanter). As this, too, is a term that comes freighted with certain assumptions and connotations, I want to briefly explain why I chose this particular term. A generic definition of a squatter (adapted from Pruijt, 2013, p. 19) is someone who is living in or otherwise using a building or a vacant piece of land without the consent of the owner and with the intention of relative long-term use. In the wealthy northwest, 'squatting' carries certain activist and subcultural connotations (see discussion in Martínez López, 2013). Globally speaking, though, squatting is a much more heterogenous practice. It is also incredibly widespread, with the majority of the world's squatters living in the Global South. My use of the term 'squatting' is inspired by Vasudevan's (2015) efforts to 'work across the divide' between the informal settlements commonly associated with the Global South and the "political acts of occupation in cities of the North'. The term allows me, again, to make a distinction between the actual people who inhabited the Sorgenfri camp and the homogenising category 'vulnerable EU citizens'. It focuses on a practice (what people do, rather than who they are), one that is of immediate relevance to my topic. I believe it is also a more accurate description of their situation than terms like 'homeless'. For me, the term 'squatter/s' also signals a preeminent political subjectivity. As the investigative journalist Robert Neuwirth (2005) writes at the conclusion of his book Shadow Cities,

The world's squatters give some reality to Henri Lefebvre's loose concept of the 'right to the city'. They are excluded, so they take. But they are not seizing an abstract right, they are taking an actual place: a place to lay their heads. This act - to challenge society's denial of place by taking one of your own - is an assertion of being in the world 
that routinely denies people the dignity and the validity inherent in a home. (p. 311)

In using the term, I wish to highlight how the actions of the squatters of the Sorgenfri camp challenged the exclusions of the existing normative orders of citizenship at both the local, national, and European scales.

\section{'Who Counts as Roma?'}

The question of who counts as Roma (Surdu, 2016) is a complex and politicised one in the Swedish context, as in much of Europe (McGarry, 2014; Vermeersch, 2012; Vermeersch \& van Baar, 2017). It is a question that has significant socio-political implications: It is central to the contemporary politics of recognition, historical justice, minority rights protection, and socio-economic integration. Just as the category of the 'vulnerable EU citizen' should be approached with some caution, the use of the term 'Roma' therefore needs to be carefully considered. Notably, there are significant and persistent disagreements among researchers working on issues related to Roma over the core ontological question 'who are the Roma?'. In academic and policy discourse, 'the Roma' are variously represented as a distinct ethnic group, an itinerant people (i.e., nomads), a national minority, a political identity, a socially marginalised and excluded 'underclass', and a racialised social category/formation (for an overview of core conceptual debates in Romani studies, see Law \& Kovats, 2018; McGarry, 2014; Surdu \& Kovats, 2015; Tremlett, 2014). The gradual development of a supra-national EU framework on Roma integration has also contributed to re-frame the Roma as a transnational European minority (Vermeersch, 2012). While I cannot possible do justice to the intricacies of these debates in this short space, I do want to highlight a couple of conceptual issues that are particularly relevant to the present study.

First of all, I want to emphasise that I understand the European policy category of 'the Roma' to be an umbrella term, used to refer to a heterogenous and internally diverse set of groups. For example, the Council of Europe includes the following groups under the broad rubric of 'the Roma': Roma, Sinti (Manush), Kale, Finnish Kaalé, self-identified 
Gypsies and Travellers, Romanichals, Yenish, and populations designated under administrative terms like the French Gens du Voyages (see Council of Europe, 2012). The differences that matter are not just ethnic or linguistic ones. The Roma are also diverse along a number of other dimensions, such as class/socio-economic position, employment, education, citizenship/legal status, occupational history, and migration experience (cf. argument in Tremlett, 2014). There is a strong tendency in the current Swedish debate to treat 'vulnerable EU citizens' qua 'Romanian Roma' as one undifferentiated collective in a way that, arguably, obscures important differences and divisions within the 'group'.

Having said this, I also want to stress that I am not primarily interested in whether those who are labelled as 'vulnerable EU citizens' self-identify as Roma or not. This study does not address questions of Roma identity per se. Rather, I am concerned with in how the category is conjured-up and mobilised or, alternatively, negated and made invisible in the context of the government of 'vulnerable EU citizens' in Malmö. Specifically, I am interested in how those who lived in the Sorgenfri camp were, and continue to be, racialised as Roma - that is, how they are explicitly and implicitly ascribed certain racialised identities and characteristics. But I am also equally interested in how questions of anti-Roma racism are deflected, ignored, or 'invisibilised' (Ryan Powell \& van Baar, 2019). Here, I am inspired by a relatively recent body of literature that approaches questions concerning the exclusion, exploitation, and marginalisation of Roma communities through the lens of critical race theory (Kóczé, 2017; Magyari-Vincze, Petrovici, Raț, \& Picker, 2019; Picker, 2017; Picker, Murji, \& Boatcă, 2019; Ryan Powell \& van Baar, 2019). I use the definition of race presented by Goldberg and Solomons (2002):

$[\mathrm{R}]$ ace is a medium by which difference is presented and otherness produced, so that contingent attributes such as skin color are transformed into supposedly essential bases for identities, group belonging and exclusion, social privileges and burdens, political rights and disenfranchisements. (p.3) 
From this follows a definition of racialisation as the process whereby essentialised difference is presented and otherness is produced. Crucially, this is not limited to the discursive construction of essentialised difference and Otherness but includes material process that produce differences between people and places along racialised lines (cf. argument in Picker, 2017).

Why 'race', why not 'ethnicity'? In insisting on 'race' as an analytical category, I am, of course, not suggesting that there is a scientific basis to ideas about racial inferiority/superiority. As Ahmed (2002) notes, 'Racialization is a process that takes place in time and space: "race" is an effect of this process, rather than its origin or cause' (p. 46). I follow Lentin (2017b) and others who argue that that merely replacing race with terms that appear more explanatory of difference (primarily, ethnicity) is paradoxically to take scientific racism on its own terms: reducing race to its particular 19th and early 20th century variant (i.e., biological race) while ignoring the longer history of race as it has been, and continues to be, bound up with European colonialism and modernity (cf. Hesse, 2007; Picker, 2017). Yildız and De Genova (2017) make a similar argument about the concept of ethnicity, arguing that it tends to "conjoin[s] cultural particularity with genealogy thereby re-stabilising the pseudo-biological foundations for the very "group"-ness of the ostensible group [in question]' (pp. 7-8), while disregarding the historically specific sociopolitical dynamics that contributed, and continues to contribute, to the production of the group qua a group. In his writing on post-racialism and 'colour blindness', Goldberg (2006, 2009) argues for an analytical distinction between anti-racialism and anti-racism. While the latter refers to efforts to confront social inequalities along racial lines, the former signifies attempts to do away with categories and prejudice based on phenotype or origin. Goldberg suggests that anti-racism and antiracialism necessarily need to go hand in hand. However, if anti-racialism is detached from the anti-racist ambition to change the status quo of racial inequality, it risks undermining anti-racist struggle altogether by making it impossible to identify and name racism. 
Circling back to my original question, 'who are the vulnerable EU citizens?', I would suggest that the language of 'vulnerable EU citizens' is reflective of a commitment on the part of the Swedish government and authorities to a particular Swedish brand of anti-racialism (see Brännström, 2016). Certainly, the use of a facially neutral term like 'vulnerable EU citizens' is preferable to the aggressively racialising discourse of 'the Roma problem' that is prevalent in many other countries in Europe (Aradau, 2009; Pusca, 2010; Yıldız \& De Genova, 2017). Nevertheless, the negation of the Roma identities and experiences of 'vulnerable EU citizens' makes it difficult to name the racism that they are subjected to. As I discuss in my analysis of the fallout of the evacuation and demolition of the Sorgenfri camp (in chapter six), it also sometimes works to deflect claims for Roma minority rights and protections. Furthermore, it is consistent with a tendency to displace the problem of anti-Roma racism to an elsewhere - either to other countries (especially Romania) or to the shameful past of Swedish 19th-century state racism towards Roma and Travellers. The aforementioned report of the National Coordinator for Vulnerable EU Citizens, Martin Valfridsson, illustrates this point: On the one hand, it emphasises that that "the majority of the group" are Roma, and subject to ethnically-based discrimination in their home countries (SOU 2016:6, p. 13). On the other hand, it actively denies that questions of discrimination and racism have any bearing on their situation and treatment in Sweden, refusing to name the group as 'Roma' except for in reference to the discrimination they allegedly suffer from in Romania. In this context, it bears noting that Roma EU citizens without a right of residence (i.e., 'vulnerable EU citizens') are explicitly left out of the Swedish National Strategy for Roma Inclusion (Kulturdepartementet, 2016) and from most official municipal programs for Roma integration.

\section{EU Citizenship and Freedom of Movement}

In order to understand how the 'vulnerable EU citizens' becomes thinkable as a category in the first place, it is necessary to understand how EU citizenship is constituted, including how the rights of mobility and residence are defined in EU law. Freedom of movement is often said to 
be a cornerstone of EUropean integration, and it is generally recognised as the core distinguishing feature of EU citizenship. However, the right to freedom of movement is not an absolute and unrestricted right. Indeed, it never has been.

The 1957 Treaty of Rome, which brought about the creation of the European Economic Community (EEC), famously set out the 'four freedoms' that would come to serve (and which still serve) as the basis for the common market. These included the freedom of movement of capital, goods, services, and labour. Initially, it was only workers who were allowed to move freely within the EEC-region. Indeed, as Meehan notes, the first EU citizens were citizens-as-workers, not citizens-ashuman-beings (cited in Chatty, 2015, p. 90). This is telling of the notion of freedom that is articulated in the founding treatise of the EU. Walters and Haahr (2005) suggest that the Treaty of Rome and the subsequent Treaty of Maastricht exhibit an altogether market-oriented rationality of government. The Treaty of Rome, in particular, treats freedom as an instrument of economic integration and growth rather than as an abstract right held by individuals:

[The] Treaty's freedom is one that seeks to nurture economic processes, to establish the conditions for certain economic mechanisms to play themselves out. These are processes which require the possibility that workers can 'move freely within the territory of the member states', not because it is a fundamental human right vested in a free subject, but with more specific economic purposes: To 'accept offers of employment actually made' and to 'stay in a member state for the purpose of employment'. (Walters \& Haahr, 2005, p. 46)

In other words, rather than being an inalienable right held by individuals qua citizens, freedom of movement is here 'contextualized and tied to various specific activities and practices’ (Walters \& Haar, 2005).

Over time, the right to freedom of movement has been gradually extended to more and more people. With the 1992 Treaty of Maastricht, freedom of movement was redefined as a right belonging to all EU citizens, defined in the Treaty as 'every citizen who is a national of a Member 
State'. As Aradau, Huysmans, Macioti, and Squire (2013) argue, mobility is therefore "no longer simply an economic opportunity and a vehicle of economic integration between states ... rather it creates the conditions for demanding a European polity that is defined by European citizens with a common status and identity' (p. 141). In this sense, EU citizenship is also fundamentally a 'a citizenship for migrants' (Chatty, 2015): It is defined by and enacted through movement across national state borders, and it treats transnational mobility as a vehicle for the creation of a supranational identity (see also Yıldız \& De Genova, 2017). That said, the right to freedom of movement remains subject to certain conditions and limitations, purposely designed to restrict mobilities that are deemed to be excessive or otherwise problematic, not least so-called 'social tourism' (Chatty, 2015, p. 67ff; P. Hansen, 2000, 2015).

Today, freedom of movement is primarily regulated in the European Union Directive 2004/38/EC (hereinafter the Free Movement Directive). ${ }^{8}$ The Directive, which came into force one day before the 'Big Bang' Eastward Enlargement of the EU, on April 30, 2004, establishes a right of EU citizens to 'move and reside freely within the territory of the Member States' ${ }^{9}$ However, the basic right of residence is limited to an initial three-month period. The only ones to qualify for a continued right of residence are those (and, with some exceptions, their dependants) who are formally employed or self-employed or have 'sufficient resources for themselves and their family members to not become a burden on the social assistance system of the host Member State'. Moreover, prospective residents are required to register with the relevant authorities and show proof of "comprehensive sickness insurance in the host Member

\footnotetext{
${ }^{8}$ The rules set out in the Free Movement Directive have been incorporated into the Swedish Aliens Act (Utlänningslagen). Technically, the right to freedom of movement extends to the entire Euorpean Economic Area (EEA) including (in addition to the regular EU member states), Iceland, Liechtenstein, and Norway.

${ }^{9}$ In connection with the 2004 and 2007 eastward enlargements of the EU, the majority of the 'old' member states imposed transitional restrictions on the right to freedom of movement for nationals of the accession states. Sweden was one of the only member state that did not implement such restrictions. (The other two were the UK and Ireland, the two member states that are not bound by the Schengen Agreement and that have therefore not completely 'abolished' their borders to internal EU migrants.)
} 
State' (Art. 7(1.a-b)). Mobile EU citizens who do not meet these requirements have no formal right of residence beyond the initial threemonth period. Accordingly, the right to move is a lot freer than the right to stay.

However, it is not a black and white situation. The Free Movement Directive specifies that EU citizens should not be expelled on economic grounds or as an 'as an automatic consequence of [their, or their family member's] recourse to the social assistance system of the host Member State' (Art. 14(3)). There is also a provision in the Directive which states that 'union citizens and their family members may not be expelled for as long as the Union citizen can provide evidence that they are continuing to seek employment and that they have a genuine chance of being engaged' (Art. 4(4b)). The rules themselves thus create a grey legal area, in that they allow for EU citizens to remain in another member state for an extended period of time with an undetermined status, and consequently indeterminate rights to social assistance and services.

Indeed, the rules and regulations that privilege the worker-citizen relegate those who are not formally employed or economically self-sufficient to an in-between status for which there is no official designation. This is a status that is defined primarily by what it is not (i.e., a positive residency status). Thus, in many ways, it resembles the non-status of so-called irregular or undocumented migrants (Nielsen, 2016; Nordling, 2017). However, unlike many irregular migrants, 'vulnerable EU citizens' cannot (easily) be expelled or deported. And even if they are, they can usually return again. Elsewhere, Jacob Lind and I have referred to this as the 'differential deportability' of 'vulnerable EU citizens' (see Lind \& Persdotter, 2017). As Ylldız and De Genova (2017) put it,

EU citizenship offers neither a perfect free-for-all of rights to mobility nor a completely restrictive regime of controlled movement. Rather, through the complex modulations of un/free mobility, 'free' and 'unfree' signal the co-existence and co-constitution of discrepant sociopolitical and legal statuses upheld simultaneously within a single but variegated citizenship regime. ... The fragmentations of un/free 
mobility and differential citizenship ... supply some of the decisive conditions of possibility for labour subordination, precarity, and social marginalisation. (pp. 12-13)

Furthermore, the framework on freedom of movement contains what Owen Parker refers to as a 'securitizing potentiality'. Specifically, the Free Movement Directive allows for the expulsion of mobile EU citizens on grounds of 'public policy, public security, and public health'. The provision is subject to a number of procedural safeguards. These include a requirement to ensure that expulsion orders are invoked on only an individual basis (i.e., collective expulsions are not permitted) and against individuals who 'represent a genuine, present, and sufficiently serious threat affecting one of the fundamental interests of society'. Therefore, expulsion orders may not be deployed as a measure of 'general prevention' (Art. 27(1-2)). In relation to the public health rationale, the Free Movement Directive also states that the 'only diseases justifying measures restricting freedom of movement shall be the diseases with epidemic potential'.

Notwithstanding these safeguards, EU member states have used securityrelated mechanisms to expel mobile Roma, often on the basis of 'minor illegalisms' (Aradau, 2015; Aradau et al., 2013; van Baar, 2015b; van Baar, Ivasiuc, \& Kreide, 2019). Two of the more well-known cases are the controversial mass expulsions of Roma EU citizens from France in the summer of 2010 (Gehring, 2013; O’Nions, 2011; Parker, 2012; Parker \& Toke, 2013) and the Italian security measures implemented in response to the so-called 'nomad emergency' declared by then-president Silvio Berlusconi in 2008 (Clough Marinaro \& Sigona, 2011; Hepworth, 2012). In 2010, the Swedish border police also detained and unlawfully expelled between 60 and 100 beggars and street buskers from Bulgaria and Romania for 'begging and loitering' (Persson, 2010; see also Värjö, 2011).

Crucially, in the French and the Italian cases, the mass expulsions were motivated, in part, as means to do away with the nomad camps and squatter settlements of Roma EU citizens. This is indicative of the link 
between eviction practices and the production of Roma EU citizens as deportable abject EU citizens (Hepworth, 2012; van Baar, 2017c).

\section{Key National Policy Developments 2014-2016}

The present study will mainly focus on the government of "vulnerable EU citizens' at the municipal-level. To understand the significance of some of the events and processes that I will discuss, it is useful have an overview of key national level policy developments in the time period studied.

According to Spehar et al. (2017), the national-level government has tended to take a relatively passive approach towards the question of 'vulnerable EU citizens'. Until 2015, the government left it entirely up to the municipal (and, to a lesser extent, regional) governments to 'deal with' immediate issues like rough sleeping to their best abilities. Before $2015 / 2016$, there was also considerable uncertainty about the rights of homeless EU citizens to access social services and shelter. Different municipalities thus adopted different $a d$ hoc measures and strategies on these issues. A few municipalities (like Helsingborg, Karlstad, Luleå, and Lund) set up provisional campsites where homeless EU citizens were allowed to stay in exchange for a small fee. Others (like Stockholm, Göteborg, and later Malmö) intensified their efforts to eliminate unauthorised settlements.

The first National Coordinator for Vulnerable EU Citizens, Martin Valfridsson, was appointed by the then newly elected red-green coalition government to harmonise policy and practice across the country. Working closely with ministers in government, Valfridsson spent a year (February 2015-February 2016) carrying out an official government inquiry, the result of which was the aforementioned 2016 report. In 2015, the government also independently put forward a policy package to 'combat vulnerability and beggary' and stem the influx of 'vulnerable EU citizens' to the country (see Barker, 2017). The report and the policy package overlapped to a great extent. Jointly they emphasised policy interventions in three main fields: begging/organised crime, welfare provision, and 
unauthorised settlements. The Valfridsson report also included a number of recommendations that more took the form of moral-political pronouncements than actual policies. I summarise the main ones below:

\section{Begging/Organised Crime}

The years 2014-2015 saw much debate about the link between organised crime and begging ('organised beggary' as it was dubbed by the nationalist party, Sverigedemokraterna) and whether to prohibit begging (for a comprehensive analysis see Hansson, 2019; Hansson \& Persdotter, 2019). A key component of the government's policy package was a proposal to extend anti-trafficking laws to criminalise 'the organisation of begging'. The proposal was approved by parliament and implemented in law in 2018 (SFS 2018:60). Meanwhile, the Valfridsson report urged the public to give money to established charities working in Bulgaria and Romania rather than to individual beggars. As Valfridsson argued, 'To give money to those who beg risks cementing the beggar-role, while not leading to any longterm change for the group. Childrens' education is jeopardised and the beggar-role risks being passed on to the next generation' (SOU 2016:6, p. 10).

\section{Welfare Provisions}

The Valfridsson report clarified the terms of the free movement regulations: In essence, EU citizens residing in Sweden have no rights to social assistance and services and limited rights to health care. Moreover, the report proposed a restrictive interpretation of relevant human rights frameworks. One of the most controversial recommendations of the report was to restrict access to schooling for 'children of vulnerable EU citizens' (ostensibly to protect them from being taken out of school in their home countries) and that access to social services should be further restricted so as to eliminate any 'pull factors' that might attract EU citizens from less affluent member states to Sweden (Lind \& Persdotter, 2017).

While insisting that there was no legal grounds for the public to provide assistance and services to the group, both the government and Valfridsson 
himself emphasised the role of civil society organisations (CSOs) in providing services to the population in question.

\section{Unauthorised Settlements}

A key component of the government's policy package to 'combat vulnerability and beggary' was a proposal to review and amend the Enforcement Code to simplify eviction procedures.

As I have stressed already, Valfridsson recommended a zero-tolerance approach towards unauthorised settlements and instructed the local police divisions to mobilise the Police and Public Order law to achieve this goal.

Furthermore, the Valfridsson report recommended that municipalities refrain from providing alternative (authorised) campsites. Commenting on the fact that some municipalities have opted to grant the use of land for authorised settlements, the report argued that this was not an appropriate long-term solution:

In the long run, municipally-provided campsites does not appear to be a sustainable solution. Municipalities can only provide the group vulnerable EU citizens with welfare in the form of emergency social assistance. ... Therefore, it is unclear if municipalities even have a right to set up long-term campsites for caravans or tents for a group that has limited rights to assistance. There is a severe housing shortage in many parts of the country, and there are already a number of homeless citizens. Providing campsites and allowing only a specific group of homeless individuals to stay there - especially when they are not municipal residents - may not be in accordance with the law. (SOU 2016:6, p. 70)

Notably, the policy decisions and recommendations put forward in the Valfridsson report and by the national government are by and large ones that further responsibilise local-level government and authorities. As I will show, the case of the Sorgenfri camp both shaped and was shaped by these policy developments. 


\section{Chapter Outline}

I begin the following chapter by discussing my methodological choice to 'study up'. This is followed by a discussion of my overarching analytical framework and a presentation of my concrete methods for data collection and analysis.

Chapter 3 situates this thesis conceptually at the intersection of critical migration and urban studies. It presents an historically and theoretically based discussion about the city as a distinct site of mobility control policy and practice, and it contextualises the present-day government of 'vulnerable EU citizens' within a history of local state attempts to variously keep out the mobile poor. In doing so, the chapter also discusses how representations of the Roma have long been tied to the class- and racialised politics of mobility control.

In Chapter 4, I introduce the case of the Sorgenfri camp in more detail. I trace an account of the conflicts surrounding the Sorgenfri camp and the events and processes that led up to the ultimate demolition of the settlement. I also discuss the significance of the settlement as a space of shelter and community organising.

Chapter 5 centres on an analysis of the many private complaints that were sent to the City of Malmö regarding the Sorgenfri camp. Based on these complaints, I seek to discuss the significance of popular representations of the settlement and its inhabitants as a nuisance - dirty, degenerate, and 'out of place'. I also discuss how the city government and administration reasoned about and justified the demolition of the settlement.

In Chapter 6, which builds directly on the previous chapter, I turn to consider what happened when descriptions of the settlement as a nuisance were translated into administrative and judicial discourse - that is, when the social object of the settlement was translated into the legal category of a 'nuisance'. I do so by tracing the administrative and legal process that ultimately resulted in the evacuation and demolition of the Sorgenfri camp. Throughout this chapter, I explore the detailed workings and effects of some of the legal mechanism that were mobilised by the 
Environmental Administration as well as by the property owner in their attempts to do away with the Sorgenfri camp.

In Chapter 7, I seek to broaden my focus and discuss local policies and practices with regards to 'vulnerable EU citizens' in Malmö more generally. The chapter specifically address the situation of 'vulnerable EU citizens' in Malmö in terms of their rights and access to social assistance and services and their access to public space. The chapter concludes that the last several years have witnessed a seemingly systematic - although not complete and always contested - elimination of the geographies of survival for 'vulnerable EU citizens'.

In the final chapter, I summarise my main findings and discuss their implications. I also further elaborate on my conceptual argument regarding the urbanisation of mobility controls. 


\section{STUDYING GOVERNMENT IN PRACTICE}

This thesis is broadly situated within the tradition of critical and poststructuralist thought, and it is informed by a Foucaultian governmentality style of analysis, as well as by a commitment to 'studying up' - to 'studying the powerful, their institutions, policies, and practices instead of focusing only on those whom the powerful govern' (Harding \& Norberg, 2005, p. 2011). As I explained in the introductory chapter, its overarching aim is to examine the local government response to the appearance and presence of so-called 'vulnerable EU citizens' and to document and analyse how the municipal authorities govern their conditions of stay. Thus, rather than concentrating on the individuals and collectivities who are labelled as 'EU migrants' or 'vulnerable EU citizens', I take as my object of analysis the concrete, often contested, practices of power that variously shape their living conditions and that, in fact, constitute the very categories 'EU migrants' and 'vulnerable EU citizens'.

In this chapter, I introduce my epistemological starting points and analytical framework and discuss my concrete methods of data collection and analysis.

\section{'Studying Up': Motivations and Starting Points}

The term 'studying up' was first coined by the U.S. American anthropologist Laura Nader (1969) and has since been elaborated by feminist researchers across a variety of disciplines and fields. Writing in the late 1960s, Nader called into question the tendency of anthopologists to focus solely on subjects traditionally understood as disadvantaged or Other (e.g., 'the poor', or faraway Others), and she made a case for 'reinventing' the discipline by consciously shifting the scholarly gaze 
onto actors, communities, institutions, and organisations that exercise a relatively large degree of influence and power - not least state bureaucracies. Such a shift, she argued, was imperative to more fully understand how social relations of difference and inequality are produced and reproduced, and to ensure the democratic relevance of research. As a methodological strategy, 'studying up' compels researchers to ask common-sense questions in reverse: 'to study ... the culture of power rather than the culture of the powerless, the culture of affluence rather than the culture of poverty' (Nader, 1969, p. 5). While it comes with its own set of challenges and limitations in terms of access and duplicity (see Gusterson, 1997; Mountz, 2002), it is a powerful methodological move insofar as it subverts taken-for-granted problem defintions and allows us to uncover social dynamics and relationships that would have otherwise remained under-analysed. Thus, it offers new ways of understanding and responding to social problems (Stryker \& González, 2014). Indeed, the methodological strategy of 'studying up' has been explicitly adopted by a number of researchers within the field of border and migration studies to eschew the nation-state-centric epistemology that, arguably, informs much migration-related research and subvert what Nicholas De Geonva (2013) describes as the 'persistent reification' of the migrant subject (e.g., Coleman, 2012b; Coleman \& Stuesse, 2016; Goździak, 2016; Hyndman, 2000; Mountz, 2002, 2010).

'Studying up' does not mean studying 'those who govern' (in this case, the state and municipal authorities) as if in a vacuum. It is more than a simple invocation to study powerful actors and institutions. In Nader's (1969) original conception of the term, 'studying up' actually meant tracing the interconnections between groups and organisations of unequal power (Stryker \& González, 2014). Fundamentally, it implies a relational understanding of the social world: for example, affluence and poverty are assumed to be interconnected or even mutually constitutive of one another (cf. Elwood, Lawson, \& Sheppard, 2017). In the context of immigration control, 'studying up' can mean connecting 'what goes on in the embodied frontlines of the state' to the 'embodied effects' and negotiations of such practices within communities targeted by 
immigration control (Coleman \& Stuesse, 2016, p. 529). This is also how I employ the methodological strategy of 'studying up': I seek to analyse and discuss how government power takes place and is practiced on the ground in terms of its effects in the day-to-day lives of 'vulnerable EU citizens'.

This seemed an important undertaking when I began this project in early 2015. At the time, there were no studies (published or underway) that directly addressed the government response to 'vulnerable EU citizens' in the Swedish context. Indeed, this dissertation constitutes one of the first scholarly works that specifically engage with the topic. As I discuss in the introductory chapter, the presence of 'vulnerable EU citizens' raised (and continues to raise) fundamental questions about the integrity and legitimacy of the welfare state in the face of the putative 'crises' of free movement and migration. Thus, it seemed likely that the government response would have significant consequences - not just for the 'target group' but also for the politics of migration and welfare more broadly. This interested me, personally, for a variety of different reasons.

Like so many others, I grappled (and I continue to grapple) with the weighty question of what exactly those of us committed to a politics of social justice and redistribution of global wealth should do about the nation-state - a question that is brought to its head by the fact of poverty migration. I moved to Malmö in 2013, returning to Sweden after almost a decade abroad. Having lived on unceded Coast Salish Territories in Vancouver, Canada - a city that is experiencing an ongoing and thouroughly racialised homelessness crisis - I was used (or desensitised, one might say) to encountering city dwellers in situations of acute poverty and street-homelessness. Nevertheless, I was taken aback by what seemed to me as a relatively sudden 'appearance' of street-beggars in cities and towns across Sweden. Altough I did not actually have that many illusions that the social democratic welfare-state was ever the egalitarian and inclusionary paradise it is sometimes made out to be, I still discovered within myself a kind of lingering attachment to the idea of Sweden as a 'good society' (see Amin, Lindberg, \& Dahlstedt, 2002; Pred, 1997). To some extent, the societal-scale moral panic that I outline in the 
introduction was also my own moral and political crisis. Having lived for many years in a settler-colonial setting where the idea and institutions of territorial sovereignty are intensely contested and politicised, I thought of the moral panic concerning 'vulnerable EU citizens' as a moment to seriously engage with the inherent contradictions and limitations of the welfare-state and imagine a different geography of responsibility and solidarity (Massey, 2004).

Some of the more concrete questions that animate this study came from my involvement with a Malmö-based migrant justice organisation that offers legal-advice and social support to irregularised migrants (mainly rejected asylum-seekers from Afghanistan). This work brought me into contact with many undocumented individuals, who were trying to make a life for themselves in the city with no formal rights to work and only limited access to social assistance and services. Here, I got to witness the profound impact of immigration law enforcement in people's everyday lives. In the fall of 2014, the organisation was approached by members of the activist network Solidarity with EU Migrants. The network was starting to establish relationships with the squatters of the Sorgenfri camp and wanted to exchange knowledge and resources. I was struck by the fact that the squatters were facing challenges similar to the ones experienced by many of my undocumented friends. However, as EU citizens, they were not subject to the same threat of deportation that defines the experience of being undocumented (cf. De Genova, 2002; Lind \& Persdotter, 2017). And although law enforcement was powerfully present in their lives, it was not primarily immigration law that structured their experiences but the mobilisation of a diverse set of administrative laws and order ordinances. For me, this rasied a series of practically important but also theoretically intriguing questions about the relationship between such seemingly quotidian forms of law enforcement and the politics of mobility control - questions that would come to form the backbone of the study.

In addition to the fact that my initial questions seemed to call for this type of methodology, my decision to 'study up' was also motivated by an ambition to call into question - and hopefully reframe - the terms of the 
public debate on the question of 'vulnerable EU citizens'. Back in 2015, when I started this project, there was an overwhelming focus (in the news and mainstream media, especially) on the question of who the "vulnerable EU citizens' were: whether or not they were authentically Roma, genuinely destitute and suffering, criminally organised, or victims of trafficking (cf. Hansson, 2019). This will to know (Foucault, 1990) the 'vulnerable EU citizen' (or more precisely, the EU citizen 'beggar') is exemplified by the prolific publication of non-fiction titles like the following: Vi kallar dem tiggare [We call them beggars] (Brentlin \& Israelson, 2014); Ni inger dessa människor hopp: en berättelse om tiggarna och om några som hjälper dem [You give these people hope: a story about the beggars and some who help them] (Gurt, 2015); Det kunde varit jag [It could have been me] (Olausson \& Iosif, 2015); Jag är Gina: En berättelse om överlevnad och skam i Europa [I am Gina: A story about shame and survival in Europe] (Oldberg, 2016); Varför tigger romer? [Why do Roma beg?] (Emirov, 2016); Jag kallas tiggare [I am called a beggar] (Lagerlöf \& Freiholtz, 2017); and Gatans entreprenörer [Entrepreneurs of the street] (Bergman, 2018). While these titles differ substantially in terms of tone and ideological perspective, they all nevertheless revolve around the same two questions: who are the beggars, and what are they doing here in Sweden?

The will to know 'the beggar' or 'the vulnerable EU citizen' always struck me as a slippery slope towards the kind of essentialism that urban planning scholar Peter Marcuse calls specialism. This is the tendency to explain social problems (homelessness, in particular) with reference to the characteristics of those affected, to separate the problem in question from its context and the factors that cause it by making 'a special problem of a special group' (Marcuse, 1988, p. 88). Such specialism, I would argue, not only marked (and continues to mark) the debate about 'vulnerable EU citizens', but it is also an enduring feature of research about Roma and Travellers, who are frequently singelled out as 'ethnic group(s)' to be studied in isolation from wider social formations such that their marginalisation 'comes to appear as the inevitable effect of their intrinsic ("ethnic") singularity' (Yıldız \& De Genova, 2017, p. 7). 
I decided early on that this was not going to be a study about 'vulnerable EU citizens' per se. As a researcher, I did not want to assume the existence of an identifiable 'group' ('the vulnerable EU citizens') and then proceed to set myself up as another expert on their ethnic identities, socio-economic conditions, migration trajectories, and possible involvement in organised crime. I was also apprehensive about centering my study on the experiences and voices of people labelled as 'vulnerable EU citizens'. For one thing, I did not think I had the resources and skills to do so well. I do not, for instance, speak Romani or Romanian. More than that though, I was concerned that the study would contribute to exposing sensitive information about an already intensely scrutinised and, in many ways, extremely marginalised group of people. ${ }^{10}$ This is not to suggest that such a study would not have been appropriate or worthwhile, but it would have required a carefully considered and especially rigorous research ethic.

By opting instead to study the discourses, as well as the concrete practices, of the state and municipal authorities with regards to 'vulnerable EU citizens', I have been able to turn the ubiquitous question of who they are on its head: Rather than attempting to construct a more accurate or sensitive account - an account of who they truly are - I engage with the instability of the category as such. I do so by tracing the active categorisation of 'vulnerable EU citizens' in law, policy, and public discourse. I discuss the constitution of EU citizenship and the inherent

\footnotetext{
${ }^{10}$ The ethics of doing ethnographic research with or about marginalised and oppressed groups is the topic of considerable discussion and debate within and beyond the academy (Abu-Lughod, 2008; De Genova, 2002; Katz, 1994). In the years I have been working on this project (and especially in the aftermath of the 2015 socalled migration crisis), there has been much debate within the field of border and migration studies about the ways in which migration researchers are implicated in the exclusionary and violent practices of bordering (Anderson, 2017; Dahinden, 2016; De Genova, 2013; Lentin, 2017a). For example, Joshua Hatton (2018) has made the case that research in the field of migration and refugee studies actively harms migrant subjects by facilitating mobility control efforts through symbolic (e.g., legitimation) and technical means (e.g., mapping migrant routes and otherwise providing surveillance on the targets of border policing). Similar concerns have been raised about ethnographic scholarship about impoverished and marginalised urban populations (Students of Ethnographic \& Qualitative Methods at the Eugene Lang College at the New School, 2018). Personally, I think that the fact that funding earmarked for migration related research increased so significantly in the wake of the 2015 'migration crisis' should give those of us (myself included) who have attempted to apply for such funding pause for reflection.
} 
difficulties of determining who is subject to the right of residence, as well as the slipperiness of most policy defintions of 'vulnerable EU citizens'. Related to this, I ask how the category is ethnicised or racialised - that is, how 'vulnerable EU citizens' are identified as ethnically or racially Other. This part of my analysis also considers how anti-Roma racisms are discounted and 'invisiblised' (cf. Ryan Powell \& van Baar, 2019).

While I have no qualms about my decision to 'study up', I do have some concerns that my choice to focus on government policy and practice means that the squatter community of the Sorgenfri camp and its members appear almost like shadow figures in my analysis. Therefore, I want to emphasise that I do not think of them (or of any other persons who are labelled as 'vulnerable EU citizens') as passive and powerless targets of government practices. Neither do I intend to portray the municipality (or the state) as monolithic and all-powerful. I hope that my analysis of the complex chain of events that ultimately resulted in the demolition of the Sorgenfri camp goes some way to convey the extent to which this was a dialectic process, one in which the municipal authorities repeatedly found themselves negotitating conflicting ideas and at a loss for what to do.

\section{Refuting Stereotypes?}

Before I conclude this section, I want to take the opportunity to address what I see as a tendency to want to fix 'vulnerable EU citizens' as either victims or villains. Since I started working on this project in early 2015, I have lost count of the number of times that I have been approached with a question beginning with the words 'but aren't they actually...'. Sometimes my interlocutors have been adamant to convince me that all 'EU citizen beggars' are ensnared into criminal networks. Other times, they seem to have been looking for a confirmation that 'yes, they are truly suffering', thus deserving of empathy and some spare change. Many times, questions and comments have been delivered interspersed with culturally essentialist assumptions: 'Roma are work-shy and prefer to beg'; 'Roma culture is very patriarchal. I am sure the women are trafficked'; or 'Roma have always been involved in petty crime. I remember a family that lived down the street from us...'. I will never 
know what it is like to go through life as a Roma-identified person and routinely be subjected to such popular myths, stereotypes, and racist tropes, but working on this project has definitely given me a new awareness of just how widespread they are.

An important question for research is how to relate to and respond to negative stereotypes and racist tropes. There have been a number of studies carried out in the Scandinavian countries by academic researchers who have attempted to map popular and policy discourses about foreign beggars in order to assess the accuracy of these discourses (Djuve, Friberg, Tyldum, \& Zhang, 2015; Engebrigtsen, 2012, 2015; Engebrigtsen, Fraenkel, \& Pop, 2014). The most comprehensive study to date is the one carried out by Djuve et al. (2015). Their report identifies the following widespread assumptions about Romanian Roma street workers:

1) [they] are not really poor, but spend the money earned from migration on 'palaces' in Romania; 2) the money does not reach those who really need it, but goes to organisers and traffickers; 3 ) the Roma do not want to work, but prefer to beg; 4) begging is a cover for criminality; 5) Roma people habitually lie and are thus unsuited to participation in surveys as informants; and 6) if we give the Romanian migrants money, more of them will come.

As Djuve et al. (2015) note, these negatively tainted assumptions co-exist with discourses that instead treat Romanian Roma street workers as victims of socio-economic marginalisation and institutionalised racism and that foregrounds the following assumptions and beliefs:

7) beggars and street workers earn hardly any money while in Scandinavia; 8) the Roma in particular are discriminated against, chased and harassed by the police, private security guards and members of the general public; 9) [if] crimes are committed by the Roma, it is only out of desperation and in order to secure survival for themselves and their families; and 10) if they were equal opportunities, the street workers would rather work than beg.

Djuve et al. (2015) attempt to evaluate the validity of these claims. Based on a large-scale survey carried out among foreign street workers in the three Scandinavian capitals (Copenhagen, Oslo, and Stockholm) and 
supported by 'qualitative fieldwork in each city and in Romania' (p. 12), the team goes through each one of the above listed assumptions and assesses their accuracy (for a summary of their findings see, Djuve et al., 2015, pp. 143-144) . They conclude that,

[w]hile there is some truth in several of these assertions, our data refute some of the harshest stereotypes about Roma beggars. They are definitely poor, they are not organised by traffickers, the money is sorely needed and spent on necessities, and criminal activities are not closely associated with begging. Some assertions are almost self-evidently true; the generosity of strangers, NGOs and public institutions is critical for maintaining the practice of migration. The claims of the supporters of the Roma are not fully verified either ... there is definitely money to be gained from migration. The determination to endure the hardships of being a street worker is clearly motivated by the income opportunities available in the Scandinavian capitals, in combination with the very scarce and ever-diminishing opportunities for gaining an income at home. (p. 143).

These are significant findings that might contribute to a more nuanced popular and policy debate. Indeed, the study has so far been cited in a number of government reports (see for example Socialstyrelsen, 2017a; SOU 2016:6). That said, I am not convinced that the strategy deployed in Djuve et al. (2015), as well as in other similar studies (see, for example, Engebrigtsen et al., 2014), is sufficient to challenge widespread myths and stereotypes about 'foreign street workers' and 'vulnerable EU citizens'. Unlike Djuve et al. (2015), I do not believe that it is 'the lack of systematic descriptions' of the group in question that has 'produced public and political debates in which all sides draw on popular myths and anecdotal evidence to argue their case' (p. 137). I remain skeptical of the idea that popular myths and stereotypes arise from an objective lack of knowledge. The fundamental problem at play here, I believe, is not ignorance on the part of policy-makers and the general public. Rather, I think we need to understand the myths that mark current discourses on 'foreign street workers' (and 'vulnerable EU citizens' more generally) as being thoroughly embedded in relations of power and vested interests. To a certain extent at least, people believe what they want to believe. 
The post-colonial theorist Homi K. Bhabha (1999) writes that the stereotype is a 'paradoxical mode of representation' as it constantly vacillates between what is supposedly already known and therefore needs no proof and 'something that needs to be anxiously repeated' because it can never really be 'empirically proved or logically construed' (p. 370). In Bhabha's (1999) reflections, the stereotype is a simplification not primarily because it constitutes a 'false representation of a given reality' but because it is 'an arrested, fixated form of representation' that denies the 'play of difference' (p. 374). To ask if a stereotype is true or false, then, is to assume that it is at all possible to know if, say, 'Roma do not want to work'. Indeed, this very question assumes that the Roma (or at least, the Roma who beg on the streets of the Scandinavian capital cities) exist as a unified group with shared preferences that are knowable in any objective sense. ${ }^{11}$ As Bhabha (1999) puts it, expert-knowledges are typically called upon to satisfy the 'impossible desire' for some kind of fixity (p. 376). Under conditions of colonial or racialised domination, this is the desire for 'pure and undifferentiated origins' that will explain and justify the distinction between colonised and coloniser by establishing that the two are indeed objectively different from one another, thus legitimising the subordination of one by the other. Something similar can be said about the stereotypes that circulate about 'Roma street workers'/"vulnerable EU citizens'. That is, these stereotypes are meaningful because they facilitate and legitimise certain policies and practices. We can think here of the individual who convinces herself that all EU-citizen beggars are criminally involved as a more or less conscious (or perhaps, sub-conscious) strategy to navigate the uncomfortable encounter with the poor Other (see discussion in Hansson, 2015).

According to Bhabha (1999), the most meaningful way to interrogate a stereotype is not to ask if it is true or false or if it is good or bad based on some already established normative basis. Instead, he argues for the

\footnotetext{
${ }^{11}$ To be clear, the report by Djuve et al. (2015) repeatedly emphasise the need to consider 'Roma street workers' as an internally diverse population, yet it leaves the basic notion of an overall 'group' that shares certain measurable characteristics unquestioned.
} 
necessity of engaging with the 'process of subjectification made possible ... through stereotypical discourse' (p. 370). This involves considering the regime of 'truth' of which the stereotype forms a part and the work it does in terms of facilitating certain arrangements of power.

The question I want to pose to readers who are looking for straightforward answers to questions beginning with the words 'but aren't they actually...', or who picked up this thesis in the hope that it would provide them with objective knowledge about 'vulnerable EU citizens' as a group, is this: Why do you need to know this? Where does the desire for fixity come from? Why is it so important to know if they are villains or victims? And why, in the first place, do some of us find it so difficult to move past the notion of unified and at least somewhat homogenous group? Why this insatiable will to know the 'vulnerable EU citizens'? why not accept that those who are labelled as such are each of them just as complex and contradictory as the rest of us?

\section{Brief Reflections on Activism and Research}

Like many critical researchers, I do not believe in a strict separation between knowledge production and activism (Fuller \& Kitchin, 1981) or in the possibility of objective social science research (see Haraway, 1988). Academic knowledge production is never an objective exercise: It relies on the embodied and situated perspective of the researcher, with theory serving as a kind of magnifying glass that accentuates certain elements while blurring others (Haraway, 1988). As researchers, we are never outside the events we are studying; therefore, 'we cannot retreat into abstract analysis and ethical neutrality' (D. Smith, 1976, p. 84). There is no neutral vantage point. Instead, the challenge is, as Donna Haraway (1988) puts it, to 'become answerable for what we learn how to see' (p. $583)$.

While I would not go so far as to call myself and activist researcher, I recognise that my research process is ultimately inseperable from my involvement in social- and migrant-justice activism and community work. As I mentioned already, many of my initial questions grew out of this work. In practical terms, I have been directly involved in the support work 
in and around the Sorgenfri camp, albeit in a minor role. For example, I attended meetings and helped organise food deliveries to the squatters in the immediate aftermath of the demolition of the settlement. I have also participated in the work of the street-law collective Centre for Social Rights. I sat in on their meetings on and off for about two years (20152017) and helped write a short report to the United Nations Special Rappoteur on Adequate Housing (Leilani Farha) on behalf of the collective. Moreover, I have volunteered at the overnight facility operated by Kontrapunkt. My involvement in these efforts, and in the broader activist milieu, afforded me easier access to the kinds of information and knowledge that circulate in community organising circles. Malmö-based researcher Maja Sager (2011) refers to this the 'epistemological privileges' of being involved in social movement activism (p. 103). My analysis is also indebted to conversations that I have had with people in these contexts, which is not to say that I always agree with the specific groups that feature in the study.

\section{Conceptualising Mobility Control and Government}

One of the core assumptions that guide this study is, again, that the category of 'the migrant' is a juridico-political as well as a social construction. From this follows that it cannot be taken for granted and treated as if it had a fixed, singular, and generic meaning. Thus, rather than accepting the categories of 'the migrant' and 'migration' as selfevident objects of analysis, we might reverse the question and ask how certain forms of mobility have come to be defined as migration in law, policy, and discourse. The notion of mobility is useful in that it serves to de-naturalise the bounded and static categories of citizens, migrants, ethnicity, and nationality that are common within migration scholarship and within social science research, more generally. It makes visible the fact that the legal and policy frameworks of immigration and nationality continuously constitute and reconstitute 'migrants' as a distinct category of human mobility. As Nicholas De Genova (2013) puts it, 'if there were no borders, there would be no migrants - only mobility' (p. 253; see also Anderson, 2017; De Genova, 2007, p. 425). 
Importantly, for the purpose of this thesis, the concept of mobility also facilitates an analysis of how mobilities at different scales - and the regulation thereof - are interconnected. I use it to consider how the boundary between free movement and migration is constituted and how certain mobile EU citizens are problematised as (unwanted) migrants even though their border-crossings are not formally designated as 'migration'. It also allows me to examine how the abilities of 'vulnerable EU citizens' to move about and inhabit the city are connected to their abilities to move about and inhabit the larger political space of the EU. I use the term 'mobility control' to refer to the ways in which the state authorities regulate and otherwise attempt to govern the access, entry, and removal of mobile subjects from its territory, but my definition is not limited to immigration policy and enforcement in the narrow sense of the term. Quite the opposite. I am intead interested in forms of mobility control that exceed the conventional, direct forms of immigration law enforcement.

\section{Governmentality as a Toolkit for Political Analysis}

To study mobility control by studying how the state authorities intervene to categorise and regulate people on the move requires an analytical framework for political analysis. As previously stated, this thesis is broadly informed by Foucaultian post-structuralist theory and by the tradition of governmentality studies (Burchell, Gordon, \& Miller, 1991; Foucault, 2003, 2007; Walters, 2011, 2015). In brief, this is a critical approach to social and political research that adresses'the changing ways in which political authority, as well as those who contest that authority, pose the questions: How should we govern? What should we govern? Why do we need to govern?' (Walters \& Haahr, 2005, p. 6). Governmentality analysis takes as its starting point the idea that political struggles and processes are always 'conflicts over meaning' (p. 7). Thus, it builds on and extends post-structuralist discourse theory. The approach is utilised by migration researchers to make sense of various aspects of the global so-called 'migration regime' (Pott, Rass, \& Hrsg, 2018) including the role of advanced biometric technologies (see Amoore, 2006), the regulation of asylum-accomodation (Darling, 2011), the 
genealogy of technologies of expulsion (Walters, 2002a), and the growing salience of security discourses and measures in the governance of migrations (Bigo, 2002; van Baar, 2017a).

Michel Foucault dedicated his intellectual life to tracing the formation of ideas and investigating the relationship between power and knowledge through a distinct and rather eclectic style of philosophically oriented historical research. The term 'governmentality' (gouvernementalité) is an amalgamation of the two words 'government' (gouvernement) and 'mentality' (mentalité), signalling Foucault's interest in the relationship between statecraft and systems of 'power-knowledge'. The term is closely related to another key concept in the Foucaultian lexicon, namely 'biopolitics'. In short, 'biopolitics' refers to a distinctly modern form of power (a governmentality, if you will) that operates at the scale of the population and takes administration of life and populations as its object: 'to ensure, sustain, and multiply life, to put this life in order' (Foucault, 1990 , p. 138). Foucault elaborated on both terms (governmentality and biopolitics) in his later work, most notably in his 1975-76, 1977-78, and 1978-79 lectures at the Collège de France. Coinciding in time with the publication of two of his most famous works, Discipline and Punish (1977) and The History of Sexuality (1978), these three lecture series mark the moment in Foucault's intellectual trajectory at which he turned his attention to questions concerning state formation and statecraft.

Foucault died prematurely from AIDS in 1984, before he had the opportunity to turn the material from the lectures series into a major publication, but the lectures were transcribed from audio recordings and published posthumously. Over the years, they have come to form the basis of what is effectively an entire school of social and political theory, dedicated in large part to the analysis of liberalism and neoliberalism as distinct arts of government. The 1975-76 lecture series - published in English under the title Society Must Be Defended (2003) - traces a genealogy of state racism, detailing the emergence in the 18th century of a distinctly biopolitical racism which revolved around the theme of racial purity (more on this below). In the subsequent 1977-78 lectures Security, Territory, Population (2007) - Foucault broadens his focus to 
consider the development of political thought and technologies of government from the ancient Greek and early Christian notion of 'pastoral power', via early modern theories of the raison d'état and Polizeiwissenschaft, to the modern biopolitical welfare state. The final lecture series in the trilogy - The Birth of Biopolitics (2010) - investigates the specific genealogy of neoliberal government.

Broadly speaking, Foucault's work on governmentality and biopolitics is animated by an ambition to de-centre dominant theories of the state as a monolithic and stable institution and call into question the idea of 'sovereign power'. Foucault (1990) famously argued that the rise of what we call modernity involved a transformation in the way power operates, from 'sovereign power' to 'biopolitics': whereas previously the sovereign's power was essentially grounded it the right to 'take life or let live', this was gradually 'replaced by a power to foster life or disallow it to the point of death' - 'to make live and let die' (p. 138).

Foucault's core argument, as regards the state, is that it is not an autonomous source of power but rather a particular form that government has taken in the modern era (see Rose \& Miller, 2008). Thus, he speaks of the governmentalisation of the state (Foucault, 2007). From this follows that state formations such as the modern municipality, the nationstate, and the European Union must be understood and treated as 'the historically specific, contestable outcomes of various practices of governing' (van Baar, 2011, p. 7). This argument, in turn, relies on an analytical distinction between state and government. Foucault understands government in a comprehensive sense, as an activity or practice which aims at directing human behaviour. He derives this concept of government from an analysis of a series of 16th century manuals on the 'art of government', wherein government is taken to refer to a broad and heterogenous set of practices aimed at governing conduct through a variety of different means, ranging from the overtly violent and coercive to the consensual. As Foucault himself states in the 1982 article 'The Subject and Power',

This word [i.e government] must be allowed the very broad meaning 
which it had in the sixteenth century. 'Government' did not refer to only the political structures or the management of states; rather it designates the way in which the conduct of individuals or states might be directed; the government of children, or souls, of communities, of families, of the sick. It did not cover only the legitimately constituted forms of political or economic subjection, but also modes of action, more or less considered, which were designed to act upon the possibilities of action of other people. To govern, in this sense, is to structure the possible field of action of others. (p. 790)

Accordingly, government cannot be understood simply as that entity which holds the sovereign power to formulate and enforce the law. Government as a practice is not the exclusive domain of conventionally defined state-institutions, and it involves a diversity of means, including ones that seek to guide and shape the conduct and decisions of others through positive incentives and the creation of socio-cultural norms (see Rose, 1999)..$^{12}$

This capacious concept of government builds upon and extends Foucault's overall theory of power and his emphasis on the productive dimensions of power. For Foucault, power is never simply coercive or repressive. Nor should it be understood as a stable entity that can be possessed and wielded against others in straightforward acts of domination or coercion. According to Foucault, power is dispersed, networked, and pervasive - it is an 'endless and open strategic game' (Gordon, 1991, p. 5). As a practice, it is enacted rather than possessed (Foucault, 1990; see also Rose, 1999), and one of its primary expressions

\footnotetext{
${ }^{12}$ Notably, Foucault's analytics of government and his emphasis on diffuse and productive forms of power shares certain similarities with the scholarly discourse on contemporary, non-sovereign forms of governance (for an overview of this field, see Chakrabarty \& Bhattacharya, 2008). This discourse, which emerged in the fields of political science and organisation studies in the late 1980s, seeks to account for the growing interdependencies between state authorities and external economic and social actors and for the transfer of authority and power from the national state to supranational networks and organisations such as the EU, the International Monetary Fund (IMF), and the World Trade Organisation (WTO) that marks the current era of capitalist globalisation. This literature follows a Foucaultian approach insofar as it treats government as a set of processes rather than as a stable institution. However, in emphasising a distinct break between conventional forms of government and 'new', dispersed, networked, and non-sovereign forms of governance, it attributes a stability to 'old' forms of government that Foucaultians argue never actually existed, except for as a conditional and temporary achievement (for an extended critique of the governance discourse see Larsson, Letell, \& Thörn, 2012; Lemke, 2007).
} 
is productive: 'power produces reality; it produces domains of objects and rituals of truth' (Foucault, 1991, p. 194). In 'The Subject and Power', Foucault (1982) elaborates a concept of 'the principle or basic nature of power':

Obviously the bringing into play of power relations does not exclude the use of violence any more than it does the obtaining of consent; no doubt the exercise of power can never do without one or the other, often both at the same time. But even though consensus and violence are the instruments or the results, they do not constitute the principle or the basic nature of power. (p.789)

Instead, he argues, power is,

a total structure of actions brought to bear upon possible actions; it incites, it induces, it seduces, it makes easier or more difficult; in the extreme it constrains or forbids absolutely; it is nevertheless always a way of acting upon an acting subject or acting subjects by virtue of their acting or being capable of action. A set of actions upon other actions. (p.789)

To govern, then, is to 'to structure the possible field of action of others' (p. 790).

Known as an eclectic and experimental thinker, Foucault did not provide a single, clear-cut definition of the term 'governmentality' (Rose, O'Malley, \& Valverde, 2006). It features in his writing as a generic analytical term, roughly equivalent with 'governmental mentality or rationality', a specific way of thinking about governing as an activity (Gordon, 1991). However, Foucault also uses it to refer to a particular form of power, roughly equivalent with modern biopolitical and liberal rule. ${ }^{13}$ Over the years, the concept has often been equated with a form of rule that governs in the name of freedom and liberty, namely liberal or

\footnotetext{
${ }^{13}$ Indeed, Huub van Baar (2011, p. 43) identifies three distinct uses of the term 'governmentality' in Foucault's work: 1) An analytics of power that treats it as networked and dispersed, and which is concerned with the relationship between reationalities and technologies of power; 2) A particular historical process whereby the state came to assume its contemporary, modern form (i.e., governmentalisation); and 3) A particular form of power that comes close to what we might identify as liberal rule (i.e., the government of free and autonomous subjects through ostensibly positive means).
} 
neoliberal governmentality (Walters \& Haar, 2005). Thus, governmentality as a form of power is sometimes taken to be the polar opposite of sovereign rule (see discussion in Coleman \& Grove, 2009). This is not how I use the concept. I follow scholars like Magnus Hörnqvist (2010), who stress that modern forms of rule that aim to govern ostensibly free and autonomous individuals 'at a distance' co-exists and, indeed, are intimately tied to more overtly coercive and controlling expressions of power. Productive power and domination are not mutually exclusive.

Furthermore, rather than treating governmentality as a particular form of power, I prefer to think of it as a style of analysis, an 'analytical tool-kit' (Walters, 2015) that allows me to investigate the organised practices through which subjects are governed. I follow the geographer Margo Huxley's (2007) suggestion to study governmentalities by examining concrete programs aiming to shape, guide, and otherwise govern the behaviours of others and the self along with the 'rationalities intertwined in attempts to steer forms of conduct' (p. 187). To this end, I draw on a set of analytical concepts that have been elaborated by scholars associated with the tradition of governmentality studies. In what follows, I briefly outline these concepts before I move on to discuss biopolitics as a particular governmentality, one that suffuses contemporary discourses and practices of mobility control.

As Nikolas Rose notes (1999), 'the activity of government is inextricably bound up with the activity of thought' (p.8). It depends on the active and ongoing mobilisation of truths about what and who should be governed, how, and by whom (Huxley, 2007, p. 188). Indeed, political authority is always established on the basis of certain claims to truth - to knowledge of how to govern well and to what ends. As such, government is a rationalising activity. The concept of governmental rationality refers to

the changing discursive fields within which the exercise of power is conceptualised, the moral justifications for particular ways of exercising power by diverse authorities, notions of the appropriate forms, objects and limits of politics, and conceptions of the proper distribution of such tasks among [various] sectors. (Rose \& Miller, 1992, p. 172) 
I use the concept to analyse how the authorities explain and justify various interventions and how these justifications relate to broader regimes of truth and knowledge.

The concept of rationality is closely related to the notion of problematisation. Foucault uses this term in two interrelated ways: first, to describe his own method of analysis (i.e., problematisation as the putting into question of accepted 'truths') and, second, as an analytical concept to denote the process by which various phenomena come to be defined and thought of as particular kinds of 'problems'. Rose and Miller (1992) emphasise that government is fundamentally a 'problematising activity' in that 'the ideals of government are intrinsically linked to the problems around which it circulates, the failings it seeks to rectify, the ills it seeks to cure' (p. 181). Carol Lee Bacchi $(2009,2012 b$, 2012a) expands on this insight to argue that policy does not simply respond to an already existing problem. Rather, the process of policy-making entails the active representation or even production of a given phenomenon as a 'problem'. In Bacchi's (2012a) own words, 'what one proposes to do about something reveals what one thinks is problematic' (p. 21). Thus, 'policies produce "problems" with particular meanings that affect what gets done or not done, and how people live their lives' (p. 22, emphasis in original). This theoretical claim has been taken up by critical migration scholars to argue that the categorisation and problematisation of certain flows of people on the move as 'migration' - and hence as an object to be controlled or otherwise managed - is never an innocent or neutral act. In short, when we talk about a given phenomenon as a problem of migration, we are implicitly foreclosing other ways of understanding and responding to the issue at hand. We are, for example, not talking about it as a problem of global inequality or uneven development (Anderson, 2017; Castles, 2004). In this thesis, I use the concept to investigate how the presence of 'vulnerable EU citizens' in Malmö (and in Sweden) is variously defined in policy and discourse as a particular kind of problem (e.g., a humanitarian crisis, a migration problem, or an order issue).

The third and final concept that I borrow from the governmentality tradition is the concept of a governmental technology. This refers to 
concrete instruments, means, mechanisms, tactics, and vocabularies through which authority is exercised and rule is accomplished. A primary example of a governmental technology that has direct relevance to my study is the technology of the camp, which functions in the present era as a primary instrument of containment and control of migrants and racialised Others (Minca, 2015b; Picker, 2017). Another notable example, which also has relevance for my study, is the diagrams of the clean and ordered city found in the urban reform projects of the 19th century, such as the garden city model designed by Ebenezer Howard (see Huxley, 2007, pp. 196-197). The governmentality literature abounds with detailed examinations of how various calculative practices, census data, statistics, and cadastral mapping have been mobilised in the context of modern biopolitical government to render the population seeable, readable, and hence knowable to the modern state (e.g., Hacking, 1975; Scott, 1998). In chapter six, I engage with the influential work of James C. Scott (1998) on the technologies that underpin the governmentality of 'high modernism' to discuss how the authorities attempt to govern when such technologies fail or run up against their inherent contradictions.

In addition to these analytical concepts, I also draw on the notion of categorisation as a form of governmental technology, integral to the ordering of the population and the distribution of rights and entitlements. I also seek to combine the above listed concepts with a set of more spatially attuned concepts: scale and spatial tactics. (I introduce these concepts in more detail the following chapter.) A scalar analysis can bring attention to the ways in which problematisations (i.e., problem representations) often involve assumptions not just about what the problem is but also where it is. As I will discuss, the hardships of 'vulnerable EU citizens' in Malmö, insofar as these are rooted in poverty and ethnic discrimination, are often described as 'a problem' that properly belongs and should be resolved somewhere else. Drawing on the work of, amongst others, Glick Schiller and Çaglar (2011), I would also suggest that the concepts of scale and re-scaling offer useful analytical tools to conceptualise continuities and changes in the field of mobility control and 
to analyse urban mobility controls as a specific configuration of control practices.

\section{Research Design and Methods of Data Collection}

As case study researcher Michael Buroway (2009) states, we are 'living history as we do research' (p.9). This thesis project was conceived in the midst of a 'moral panic' (Hall et al., 1978), at a time when there was still relatively little in the way of a formalised government policy or strategy with respect to 'vulnerable EU citizens' at the local or national level. This made it a challenge to plan the process of data collection in advance. Instead, I have had to be flexible and adapt to the dynamic unfolding on policy and practice. ${ }^{14}$

About three months into the project, in the spring of 2015, I launched a pilot study. Taking the case of the Sorgenfri camp as my starting point, I began to collect documents and other types of data related to the case. Over time, I identified a number of overarching themes that came to form the basic structure and backbone of my analysis and that further guided the process of data collection, namely the following:

- The direct treatment of the Sorgenfri camp and its residents by the municipal authorities (e.g., in terms of infrastructure/service provision) and the administrative/legal process concerning the settlement.

- Broader policy and legislative developments with respect to the issue of unauthorised settlements at the national and municipal level.

\footnotetext{
${ }^{14}$ I experienced the first year of my working on the project (2015) as a time of uncertainty, intense debate, and thus also as a time of relative openness - a number of different policy solutions and pathways seemed to still be on the agenda. Over the years, I have followed the question around as it has been bounced from one policy area to another and back, trying to keep apace with current events and developments. During this time, I have witnessed how the public debate has subsided. Meanwhile, the uncertainty and relative openness that prevailed in 2015 has given way to a more set policy approach and strategy. This is broadly consistent with the theory of moral panics: they tend to follow an arc that begins with the veritable explosion of media interest and continues, via a restless search for a proper diagnosis and solution, to some form of resolution (cf. Cohen, 1987; Hall et al., 1978). The timing and temporal scope of the study coincides with this arc.
} 
- Social policy issues, such as the rights and access of 'vulnerable EU citizens' to social assistance, services, and shelters for the homeless.

- The everyday policing of 'vulnerable EU citizens' by streetlevel security and public order personnel, including police officers and streets and park management.

I should note here that I confirmed with lawyers at Malmö University that I did not need to obtain formal ethical approval from the Swedish Ethical Review Authority before commencing data collection.

\section{Case Study: The Sorgenfri Camp}

Broadly speaking, a case study is considered a credible and useful research methodology insofar as it enables an 'in-depth exploration from multiple perspectives of the complexity and uniqueness of a particular project, policy, institution, programme or system in a "real life" context' (Simons, 2014, p. 9). Case studies are intensive rather than extensive: Instead of looking at a few defined variables across a large number of cases, case study research focuses on the complex interaction of many factors in a single case. This makes it a fruitful methodology or research design for the kind of Foucaultian inspired, context-sensitive analysis of how political authority and power is exercised that I carry out in this thesis. As a research design frame and narrative devise, the case study format also allows me to organise and tie together a number of empirical and analytical threads.

The Sorgenfri camp was the single most talked about - and certainly the most contested - settlement in Sweden during the time period of my study. As my analysis will show, it constituted an important reference point in the wider debate about 'vulnerable EU citizens' and the question of unauthorised settlements. For one thing, it is mentioned as a kind of cautionary example in several national-level policy statements (e.g., SOU 2016:6). Locally, the case was also symbolically and practically significant for the development of municipal policy and government practices. For example, the City of Malmö's Action Plan for Poor and Socially Vulnerable EU citizens, which I discuss in chapter seven, was 
drafted in anticipation of the expected demolition of the Sorgenfri camp with the explicit aim of preventing a similar settlement from being established. Altogether, this makes the case of the Sorgenfri camp a relevant one to consider and a productive vantage-point from which to examine - quite literally - how power takes place in terms of how it is exercised and to what effects.

Following Bent Flyvbjerg's (2006, pp. 229-233) typology of case selection strategies, the case of the Sorgenfri camp could be considered an 'extreme case' - atypical rather than representative. As Flyvbjerg (2006) notes, choosing an 'extreme case' is an appropriate strategy when the objective is to 'achieve the greatest possible amount of information' about a given research subject or topic. This is because extreme cases tend to be rich in information: "extreme cases often reveal more information because they activate more actors and more basic mechanisms in the situation studied' (p. 229).

Crucially, the exceptionality and sheer visibility of the Sorgenfri camp contributed to making it a researchable object of inquiry. The significance of this only became clear to me once the settlement had been razed to the ground. Not only did this seem to make self-organising among the squatters much more difficult, it also made it more demanding for me as researcher, and for members of the general public, to monitor how the authorities continued to treat the evacuees and other homeless 'vulnerable EU citizens' in the aftermath of the demolition. As I will explain in detail in chapter seven, the demolition coincided in time with the announcement of a zero-tolerance approach towards unauthroised settlements. The strategy relies on early so-called pre-emptive removals of tent encampments on the basis of police law and public order ordinances. By design, it is decentralised and highly discretionary with little oversight and evaluation. Just obtaining police records of pre-emptive removals of tent encampments and settlements have proven to be exceedingly difficult.

This appears to be a common challenge for researchers interested in everyday internalised borders and forms of mobility control. Drawing on 
experiences from fieldwork in the U.S. South, Mat Coleman and Angela Stuesse (2016) note that research that seeks to trace the concrete and embodied operations of state power depends on a 'somewhere' where we can readily witness the practices of immigration control on the ground (p. 529). Based on their experience of attempting to study how immigration enforcement is carried out through routinised practices of traffic policing, they observe that such forms of immigration enforcement are exceedingly difficult to isolate as distinct, observable events in research practice: they are 'so embedded in the everyday that they are exceptionally hard to excavate and make a positive, certain object of critique' (p. 540). Crucially, this is not a conincidence. Internalised (and urbanised) forms of mobilty control are often purposely designed to be just so decentralised, discretionary, and geographically dispersed. Something similar can be said about the zero-tolerance approach towards unauthorised settlements that has been implemented in Malmö since the demolition of the Sorgenfri camp. It relies on routinised practices that are difficult to track without engaging in extensive ethnographic research with authorities or those who are targeted by such practices. My methodology, which depends on the analysis of written documents, allows me to trace the contours of this strategy, but it does not quite illuminate its concrete workings or how it is experienced by those who are its targets.

Of course, a case study is not a method for data collection in and of itself but, rather, a type of research design frame that may incorporate a number of methods and that allows for a degree of methodological adaptability and variability. In what follows, I account for my concrete methods of data collection and analysis.

\section{Empirical Material and Methods of Data Collection}

My primary data sources are official documents, including national and municipal policy statements and reports, court and administrative records pertaining to the demolition of the Sorgenfri camp, and minutes from council meetings. These materials are supplemented by interviews and observations. In chapter five, I also analyse and discuss a set of written 
nuisance complaints that were addressed to the City of Malmö regarding the Sorgenfri camp.

In addition to these materials, news reports and social media have been important sources of information. Early on in the research process, I set an 'alert' on Google News to get notified about relevant news items in Swedish newsmedia, and I have regularly searched the digital news media archive Mediearkivet Retriever for articles related to my research topic..$^{15}$ Throughout the thesis, I mainly use news materials to substantiate my own observations, and contextualise my analysis and arguments. Occassionally, I also analyse materials or statements derived from news reports in terms of their discursive content. However, I make no pretence of providing a comprehensive analysis of media discourse.

Social media (especially Facebook) has also been an important source of information and updates. Specifically, I followed the Facebook pages of many of the activist groups and NGOs that organised in and around the Sorgenfri camp or that work with with 'vulnerable EU citizens' in Malmö, including the following: Allt Åt Alla (Everything for Everyone); Centrum för Sociala Rättigheter (Centre for Social Rights); Nätverket för Romers Rättigheter (The Network for Roma Rights); Kontrapunkt, Läkare i världen Sverige (Doctors of the World/Médecins du Monde); Skåne stadsmission (Skåne City Mission); Solidaritet med EU-migranter (Solidarity with EU Migrants). I also followed the pages of activist and advocacy groups in a number of other Swedish cities, such as Hjälp tiggare i Lund (Help beggars in Lund), the Stockholm-based Föreningen Hemlösa EU-migranter (HEM) (The Association Homeless EU Migrants), Amnesty International Sweden, and Civil Rights Defenders to stay au jour with developments in these cities and at the national level.

\footnotetext{
${ }^{15}$ For Google News alerts and searches in Mediearkivet, I used the following search words: 'EU-migrant/er'; 'utsatta EU-medborgar/e'; 'Bulgariska/Romska/Rumänska/Östeuropeiska EU-medborgare/EUmigranter/tiggare'; illegala/olovliga/otillåtna boplatser/bosättningar/läger; 'migrant-/romska-/tiggar/tältläger'; and 'kåkstad/kåkstäder'.
} 


\section{Official Documents}

The bulk of my material consists of policy statements and plans issued by the various arms of the City of Malmö, minutes from the meetings of City Council and the city's Environmental and Social Services Committees, and documents pertaining to the legal proceedings around my case study (e.g., injunctions, prohibition orders, appeals, and court decisions). I also draw on policy statements issued by the National Government and the 2015-2016 Coordinator for Vulnerable EU Citizens.

For the most part, accessing documents has been relatively easy. Sweden has strong laws on public access to official documents, and the public officers I have contacted throughout the years have been accommodating of my requests and often generous with their time and support. At the height of the controversy surrounding the Sorgenfri camp, the Environmental Administration published a webpage with extensive information about the administrative/legal process underway, including a list of relevant documents, which made for easy access and oversight. That said, some documents have been inordernately difficult to obtain. In particular, I had some problems accessing certain 'shadow documents' strategical policy decisions that were talked about as if they existed even though there was no available paper trail for me to follow. One example is the City of Malmö's strategy document on unauthorised settlements and the minutes from the meeting of the municipal 'settlement network'. Both items were mentioned in interviews, yet when I requested to see the written documents, I received only very sparse notes from a one-time meeting. It also took 14 months from when I first requested these documents until I received a proper response. This, I believe, tell us something about the evasiveness of the policy-development process itself. I have a strong sense that, when it comes to this issue, government practice frequently precedes (as opposed to being subsequent to) the legislative and policy-development processes. Strategies emerge in an adhoc manner and are not always accounted for in official policy documents. 
Attempting to access documents from the Police Authority has also been a time-consuming and frustrating experience. Identifying the right terms and search words for the registrar to facilitate my requests required a crash course in the complex structure of the police archives. For example, I spent two full working days at the officies of the Malmö Police Authority, sifting through handwritten reports of so-called paragraph 13 interventions (i.e., instances where the police have 'removed' someone from a site for disturbing public order). I wanted to get a sense of how often the police participated in the removals of street-beggars and rough sleepers, but even with the help of two professionals (a lawyer and a police officer), it was impossible to decode the reports. On a different occasion, I requested the records of all expulsions of Bulgarian and Romanian EU nationals carried out by the Border Police in the metropolitian police regions within a three-year period. In 2010, a group of Romanian Roma street buskers were unlawfully expelled by the Stockholm-area Border Police for 'begging and loitering', and I wanted to know if there was any evidence that such expulsions were still taking place. Upon making the request, I was informed, first of all, that it would be difficult to process my request due to there not being a centralised filing system for expulsion orders, and that the records would have to be masked for privacy reasons. I specified that I was primarily interested in knowing why people had been expelled (i.e., the grounds for expulsion) and recommended that they cross out the names of the individuals affected. Nevertheless, when the records were delivered to me almost a year after I filed my initial request, all but the names of the expelled individuals had been masked over. And I could not ask them to reverse the masking by covering the names instead of the grounds for expulsion, as this would have effectively given me access to the complete records. I can only speculate about their motivations for sending me documents that were essentially useless as data, but this particular incident strikes me as a telling example of the problems of access that researchers sometimes encounter when 'studying up' the institution and practices of the police (Coleman \& Kocher, 2019; Vrăbiescu \& Kalir, 2017). 


\section{Interviews}

In total, I have interviewed ten people, two of whom were interviewed together: four municipal public officers and two police officers in strategically important roles, as well as two community organisers and one activist-lawyer. I have also interviewed an amateur local historian who blogs about the redevelopment of the Norra Sorgenfri neighbourhood.

\begin{tabular}{|c|c|c|}
\hline RESPONDENT & DATE & PLACE \\
\hline Blogger & May 25, 2015 & Sorgenfri, Malmö \\
\hline $\begin{array}{l}\text { Local police commissioner } \\
\text { (Tillförordnad polischef) }\end{array}$ & June 10,2015 & Offices of the Malmö Police \\
\hline Lawyer activist CSR & August 26, 2015 & CSR office, Malmö \\
\hline $\begin{array}{l}\text { Municipal Coordinator for } \\
\text { Vulnerable EU citizens }\end{array}$ & September $7,2015^{*}$ & $\begin{array}{l}\text { Malmö City Hall } \\
\text { (Stadshuset) }\end{array}$ \\
\hline $\begin{array}{l}\text { City Manager for Safety } \\
\text { and Security (Trygghets- } \\
\text { och säkerhetsdirektör) }\end{array}$ & September $7,2015^{*}$ & Malmö City Hall \\
\hline $\begin{array}{l}\text { Manager at City of Malmö, } \\
\text { Streets Department }\end{array}$ & September 28, 2015 & Malmö City Hall \\
\hline Solidarity activist 1 & October 6,2015 & Malmö University \\
\hline $\begin{array}{l}\text { Lawyer at the City of } \\
\text { Malmö }\end{array}$ & October 8, 2015 & $\begin{array}{l}\text { Officies of the City of } \\
\text { Malmö }\end{array}$ \\
\hline $\begin{array}{l}\text { Chief Operating Officer of } \\
\text { the Malmö Police } \\
\text { (Polisområdeschef) }\end{array}$ & April 12, 2016 & $\begin{array}{l}\text { Officies of the Malmö } \\
\text { Police }\end{array}$ \\
\hline $\begin{array}{l}\text { Solidarity Activist } 2 \\
\qquad(* \text { The two inter }\end{array}$ & $\begin{array}{l}\text { March 17, } 2017 \\
\text { Table 1. List of interviews } \\
\text { ws marked with an asterisk }\end{array}$ & $\begin{array}{l}\text { Respondent's workplace } \\
\text { vere done jointly) }\end{array}$ \\
\hline
\end{tabular}

I approached my respondents in their capacities as professionals and community organisers with expert insider knowledge, and the interviews were mainly of an expert/informat character (Kvale, 1997,p. 97). I treated them mainly as a complement to the official documents, which serve as my primary data source. The main purpose of doing them was to obtain 
information about the events and processes under study and to contextualise and triangulate some of my other materials. They aided in the interpretation of some other elements of my empirics and pointed me in the direction of further research material. To a lesser extent, I approach them as respondent interviews (focusing on the actors' views on various issues), and I use excerpts from some of the interviews as material for a more discursively oritented analysis.

The interviews were carried out face-to-face and followed an open-ended interview script (a different one for each interviewee). Each interview lasted between one and three hours. The interviews were mostly carried out at my respondents' workplaces (see table above). I recorded them on my phone and subsequently transferred the recordings to a password protected data storage drive. I took notes during most of the interviews, although mostly as a method of active listening. Afterwards, I transcribed the recordings and created a bullet-point summary of each interview. The interviews were all carried out and transcribed in Swedish. The excerpts that appear in the text have been translated by me while I was writing up my analysis. I have tried to conserve the meaning and inflection of the original statements instead of translating them word by word. Thus, for example, certain Swedish idioms have been exchanged for equivalent English ones.

Transcribing, translating, and interpreting interviews is necessarily a subjective exercise - and an exercise of power. As a researcher, I take someone else's statements, remove them from their context, and strip them of some of their nuance in order to use them as elements for my own analysis. Interview quotes become the building blocks of an analysis that those who provided them do not have much insight into (see discussion in Sahlin, 1996, pp. 49-50). This is true regardless of who the informant is, but the ethics of interview-based research are arguably different depending on whether one is 'studying up', 'down', or 'sideways' (Stryker \& González, 2014). That said, the ethics of 'studying up' are 
different from the ethics of studying down (Nader, 1969, p. 20). ${ }^{16}$ In particular, it is important to recognise the distinction between public and private spheres: it is necessary for the functioning of democracy that public institutions are open to scrutiny. There is also an ethical responsibility on the part of the researcher to report on institutions and practices that have considerable public impact or that harm certain individuals or groups, a responsibility that may come into conflict with the agreements they make with individual informants (see discussion in Gusterson, 1997). Such considerations have shaped my approach to research ethics - not just with regards to the interview situation but also more broadly.

According to Steinar Kvale (1997), there are three ethical aspects that we should always take into consideration when carrying out interview-based research: 1) active and informed consent, 2) informant anonymity and confidentiality, and 3) risk assessment (pp. 106-112). The first aspect informed consent - requires that the respondent is provided with adequate information to make an genuine decision about their participation. It is often said that consent should not be thought of as a static agreement but rather as an ongoing process in which the respondent is empowered to withdraw their participation should they wish to do so. However, this is a gold standard that is difficult to maintain in practice. In this context, it is worth noting that public officers are expected to make themselves available to the research community. I attempted to secure the informed consent of my respondent by explaining the purpose of the study and how I was going to use the interview material. I asked them verbally for their

\footnotetext{
16 There is an extensive methodology literature dedicated to the ethics of doing interview-based and ethnographic research with relatively powerless or vulnerable groups. In comparision, there is relatively few resources on the ethics of doing interviews while 'studying up' (although see Gusterson, 1997; Nguyen, 2019; Vrăbiescu, 2019a). Ghassan Hage (2009) might be right when he asserts that social scientists who are often willing to discuss the virtues of responsibility and reflexivity when doing research with subaltern subjects do not typically 'like to talk talk about the process of being inferiorized by [their] informants' or feeling powerless in the interview situation (p. 62). Scholars who adopt a methodological strategy of 'studying up' have noted that their research subjects are 'powerful, literate and read what [they] say' (Gusterson, 1997, p. 117). They talk back to the researcher, and challenge the credibility and validity of their interpretations (see Sohl, 2018; Vrăbiescu, 2019a).
} 
consent and invited them to contact me should they have any concerns or questions after the interview was over. I also promised to share my results with them in due time.

As for the aspect of informant anonymity and confidentiality, it is complicated, not to say impossible, to guarantee anonymity when carrying out interviews with respondents who are identifiable and, sometimes, relatively well-known in their professional poistions or in their roles as community activists. Of course, I asked to interview them precisely because they occupy these specific roles. Accounting for their professional roles/positions is also important to contextualise their interview quotes. Nevertheless, I have opted to refer to them by their titles or roles rather than by their names, and omitted identifiers like gender. This is a deliberate attempt to shift the focus from the respondents as individuals to their roles as professional public officers or community activists. I have also excluded any information which I deemed to be of a more private nature. The third and final aspect - risk assessment - refers to the notion that the research should be beneficial to society while minimising the risk of harm to its participants. This is a commitment that goes well beyond the interview situation; it concerns literally every aspect of the research process from the problem formulation and basic research design to the dissemination of results. I have dicussed the normative underpinnings of the project in some detail already. Here it suffices to note that I do not see any reason why the project would harm those who participated as respondents, and I hope they will think that I have done justice to their perspectives.

\section{Nuisance Complaints}

In chapter five, I analyse a set of about two-hundred nuisance complaints regarding the Sorgenfri camp that were addressed to the City of Malmö (specifically to the Environmental Administration) by private citizens 
between May 2014 and December 2015. ${ }^{17}$ The complaints were obtained through a freedom of information request to the Environmental Administration, and they have been anonymised. As I will explain, the complaints played a direct role in the demolition of the Sorgenfri camp in that they prompted the administration to launch an inspection ( $\mathrm{Sw}$ : tillsynsärende) and exerted continuous pressure on them to resolve the case. They also illustrate some of the 'moral panic' surrounding the settlement. Having said that, I want to emphasise that I do not think of the complaints as being representative of public perception or public opinion. A complaint is a distinct genre of communication: you write one when something is bothering you, and you want it to change. Many of those who made the effort to file a complaint to the city were either directly affected by some nuisance or held particularly strong views about the settlement. In other words, there is an obvious 'selection bias' at play here. I use the complaints as a window into the controversies surrounding the Sorgenfri camp and to interrogate the representation of the settlement and its inhabitants as dirty, disorderly, and 'out of place' (more on this below).

\section{Observations - My Own and Others'}

Thoughout the duration of this research project, I have carried out day-today observations in and around the city and in the Sorgenfri camp. ${ }^{18} \mathrm{I}$ have also had numerous informal conversations with residents and former residents of the settlement, as well as with other EU citizens who were begging or sleeping rough in the city. For about three months, I shared an apartment with a family from outside of Cluj-Napoca, Romania, who were otherwise street-homeless in Malmö. Informal conversations and observations shaped my method for data collection and informed my

\footnotetext{
${ }^{17}$ The fact that some individuals emailed the City multiple times with the same complaint and that there was a fair deal of back-and-forth between them and the administration makes it difficult to pin-point the exact number of complaints.

${ }^{18}$ I have lived in Malmö (close to the site of the Sorgenfri camp) for the entire duration of my PhD studies, except for four months during the fall semester of 2016, when I was abroad as a visiting PhD student.
} 
analysis in the sense that they alerted me to issues that I should explore further. That said, I did not approach my study as an ethnographic one. It has also been important for me to respect the integrity of my personal relationships with the people I have met during these years. Because I have not always been upfront about my research interests, or able to explain them clearly enough to obtain genuine consent, I have opted to leave out or decontextualise information I learned from informal conversations with the squatters of the Sorgenfri camp and other homeless EU citizens.

For these reasons, I rely on newspaper articles to anchor my account of some events discussed in the thesis. In chapter five, I also draw on journalist Erika Oldberg's (2016) biography of Gina Ionescu, who was one of the residents of the Sorgenfri camp. The book details the same course of events that I discuss in this dissertation, but from the vantage point of someone who experienced them first-hand. Given that my object of analysis is not the internal life of the settlement, and because it was not within the scope of my analysis to do interviews with the squatters, I have opted to use the book as a reference to construct a narrative frame for the case study.

\section{Methods of Analysis}

It is often said that analysis is a process, rather than a discrete activity or event, and that it is ongoing throughout the entirety of a research project. The intial naming of a topic is already an analytical move, as is the choice and demarcation of a 'field site' (Katz, 1994). 'Writing up' is also a critical part of the analytical process - not something that happens after the analysis is done. In my case, the analysis started before I even formally began the research project as I was processing the topic and formulating some of the questions that animate the study. (I suspect this is true for most, if not all, research projects.) The analysis has also been ongoing throughout the entire duration of the project, and it has happened simultaneously and in interaction with the literature study and the gathering of empirical material. My method of analysis has also evolved over the course of the research process. 
Rose et al. (2006) suggest that governmentality studies are usefully thought of, not as a distinct method, but rather as an 'ethos of investigation': a way of asking questions by focusing 'not upon why certain things happened but how they happened and the difference that made in relation to what had gone before' (p. 101, my emphasis). In this spirit, I have attempted to develop concrete analysis of concrete events and processes and to foreground questions about their mechanisms, effects, and implications (cf. discussion in Valverde, 2015). As the reader will notice, the analysis focuses quite heavily on understanding various government technologies (including relevant legal complexes) and their attendant rationalities. I also focus on questions familiar to discourse analysis - that is, how meaning is constructed and negotiatied in language and how this shapes what is possible to think, say, and do (Winther Jørgensen \& Phillips, 2002).

Having already introduced my overarching analytical framework along with some of the key analytical concepts I make use of, I want to briefly account for my concrete methods of analysis. These include standard qualitative research tools like journaling and memo writing. In an effort to systematise my rather diverse materials and begin to wrap my head around the unfolding development of policy and practice in Malmö, I created an index of all my various pieces of data: an excel-file where I noted down a brief summary of the content of each item and some preliminary points of analysis. I then used this file to create three overlapping storylines: one focusing on the controversies surrounding the Sorgenfri camp; one focusing specifically on the administrative-legal processes that led to its demolition; and one focusing on the overall development of policy and practice with regards to 'vulnerable EU citizens' in the city. This exercise, which was ongoing for the better part of the research process, helped me identify themes and categories of analysis. In order to operationalise my analytical concepts and categories (e.g., problematisation), I also devised a reading guide (see appendix), which I used to analyse policy documents and other written materials.

In chapter five of the thesis, I carry out a a type of discourse analysis, focusing on the construction of the Sorgenfri camp as a environmental 
nuisance and sanitation hazard. The analysis is based on a reading of the aforementioned nuisance complaints and selected statements by municipal politicians and public officials. To be clear, this was not intended as an open-ended or comprehensive analysis of the discursive struggles around the issues of unauthorised settlements or the specific contested case of the Sorgenfri camp. I did not set out to map public opinion or perception on the issue, or to trace discursive-political struggles within city government. Being interested in the administrativelegal categorisation of the settlement as a 'nuisance' and its significance for the decision to demolish the settlement, I wanted to explore how the categories of environmental nuisance and sanitary regulation become invested with symbolic meaning, and to delineate the discourses of cleanliness and sanitation that swirled around the process in question. In practical terms, I read the nuisance complaints multiple times over and coded the material for recurrent themes. The other statements were selected to shed light on how the representatives of the city's political leadership and public officials who were directely involved in the case spoke about the settlement as a nuisance problem.

Having accounted for some of my epistemological starting points, my overarching analytical framework, and my methods of data collection and analysis, I turn now to a theoretical discussion about the urbanisation of mobility controls. 


\section{THE URBANISATION OF MOBILITY CONTROLS}

As Bridget Anderson (2017, p. 1532) reminds us, policies and practices of mobility control are not simply about conditions of entry but also and, for my purposes, more importantly - about conditions of stay. In this thesis, I make the argument that the state and municipal authorities attempt to discourage and otherwise manage the mobilities of 'vulnerable EU citizens' by controlling how they are able, or rather unable, to access and use urban public space for securing shelter and livelihoods. I take this to represent a scalar re-configuration of control - an urbanisation of mobility controls. How might we understand this re-configuration? What is distinctive about the ways in which municipal authorities and other urban actors go about governing (or attempting to govern) issues of mobility/migration, and what are the consequences for those who are subjected to and seek to resist such forms of government?

In this chapter, I provide a theoretical discussion of these questions. I do so by bringing together two bodies of literature that are mostly disconnected from one another: the recent literature on the re-scaling of borders and mobility controls, and the legal geographic literature on urban socio-spatial control. The chapter is organised into three main parts. In the first one, I review some of the literature on city-level bordering practices. In the second part, I introduce theories of scale and develop a hypothesis about the city as a distinct scale and site of mobility control. In particular, I take up an argument that has been developed by, amongst others, Michel Foucault (2007), namely that the urban is the pre-eminent scale of so-called police power. In the third and final part of the chapter, I trace an account of the history of local-scale mobility controls, going from the early modern era to today. Here, I seek to historically contextualise the connections between mobility control and urban socio- 
spatial control and suggest that present day governance of "vulnerable EU citizens' can be usefully understood in light of the long history of state attempts to police or otherwise control mobile poor populations.

\section{The Border Inside}

In direct response to celebratory accounts of the borderless world of globalised capitalism and the 'end of the nation-state' (e.g., Ohmae, 1990), Étienne Balibar (2002) hypothesised almost two decades ago that borders are still everywhere, especially for racialised groups who are disproportionately subjected to forms of policing and surveillance that reflect and reinforce colonial and 'neo-racist' nationalist divisions (see Balibar, 1991, on neo-racism). ${ }^{19}$ According to Balibar (2004, 2009), this ubiquity of borders is evident, not least, in the case of the European Union, where efforts to develop a common market and shared polity through the abolition of internal borders have resulted not only in the fortification of the external border but also in the intensification of security and surveillance policies directed at Europe's internal Others, including the Roma.

As I mentioned in the introduction, there is a sizeable literature dedicated to documenting and analysing how the mobilities of Roma EU citizens have been, and continue to be, problematised and restricted on grounds of security (see Aradau, 2009, 2015; Aradau et al., 2013; Hepworth, 2012; van Baar, 2017b; van Baar, Ivasiuc, \& Kreide, 2019). Some have also argued that the securitisation of Roma mobilities amounts to a form of

\footnotetext{
${ }^{19}$ Balibar's hypothesis has become a touchstone for scholars within the ever-growing field of critical border and migration studies. In particular, scholars have elaborated on Balibar's observation that borders (and bordering practices) are increasingly becoming dispersed both inside and outside of state theory. In the border and migration studies literature, this is usually referred to as the simultaneous externalisation and internalisation of borders (for an overview of the field, see Burridge et al., 2017). Notably, Balibar's everywhere border hypothesis has been critiqued on two main accounts: first, for representing the border as ubiquitous, and thus conveying a vision of the state as omnipresent and all-powerful (see discussion in Burridge et al., 2017) and, second, for failing to acknowledge that the border is not equally everywhere for everyone (Johnson \& Jones, 2014). This second criticism might be a valid in the case of certain interpretations of Balibar's hypothesis, but it completely fails to address his original proposition, namely that 'the management and policing of borders establish and maintain "a world apartheid", which institutes a "colour bar" that runs through all societies' (see discussion in De Genova, 2013, p. 1192).
} 
everyday, biopolitical and racialised bordering of the space of Europe (Fekete, 2014; Solimene, 2013; Tervonen \& Enache, 2017; van Baar, 2015a; Wemyss \& Cassidy, 2017; Yuval-Davis, Wemyss, \& Cassidy, 2017). Notwithstanding this emphasis on biopolitical and everyday bordering and security practices, few within the field of critical Romani studies have given explicit attention to the fact that the government of Roma EU citizens on the move frequently involves a simultaneous municipalisation and urbanisation of borders and mobility control practices. One notable exception is Huub van Baar's (2017c) recent work on the concept of 'evictability', which starts from the observation that the biopolitics of expulsion and deportation are continuous with and, in fact, depends on frequent cycles of forced evictions and other securitising measures targeted at impoverished and racialised Roma EU citizens (see also Fouteau et al., 2014; Legros \& Vitale, 2011; Picker, 2017). According to van Baar (2017c), understanding the impact of the contemporary European border regime on minority EU citizens requires a denationalisation of the concepts and methods of migration studies and an renewed attention to 'urban governmentalities' concerning the management of issues like public order, neighbourhood redevelopment, and social housing provision. Building upon van Baar's argument, I attempt to explore the specific role of municipal authorities and other urban actors in the government of mobile Roma EU citizens and other 'vulnerable EU citizens' in Sweden. This puts the study into conversation with the broader literature on migration governance and the city.

Over the past several years, there has been a growing interest on the part of social scientists in cities as spaces of migration governance (see Darling, 2016; Glick Schiller \& Çağlar, 2011). In particular, a number of studies have called attention to the shifting role of municipalities and other sub-national levels of government in creating and enacting exclusionary mobility control policy. In the United States, scholars have analysed the top-down strategic devolution of immigration authority to lower level jurisdictions and the expansion of interior immigration enforcement following 9/11 (e.g., Coleman, 2009, 2012a, 2012b; Ellis, 2006; Park, 2019; Walker \& Leitner, 2010). Meanwhile, Monica Varsanyi 
(2006, 2008, 2010a) has charted the development of bottom-up attempts at 'immigration policy activism' in U.S. cities and (sub-federal) states. Varsanyi specifically highlights the widespread creation of new city ordinances and enforcement strategies that intentionally, although indirectly, work to exclude undocumented migrants by intervening into the spaces of their everyday lives (see also Motomura, 2008). Similar strategies of indirect immigration enforcement exist also in Europe. Since 2012, when Theresa May (then the U.K. home secretary) announced her government's intention to create a 'hostile environment' for so-called illegal migrants, British researchers and migrants' rights advocates have observed a proliferation of everyday bordering practices that rely on the enforced precarity and 'organised abandonment' (Bhandar, 2018) of irregularised migrants, including destitute so-called EU migrants (CORAM, 2013; Corporate Watch, 2018; Garapich, 2016; Jones et al., 2017; Keenan, 2017; Price, 2014; Yuval-Davis, Wemyss, \& Cassidy, 2018). European research has also found that anti-begging legislation is being used strategically in a number of European cities (Florence, Italy, being one example) to control the mobilities of unwanted groups, especially impoverished and racialised Roma EU citizens (Fekete, 2014; Pailli \& Simoni, 2016).

As my literature review suggests, the mechanisms of exclusionary municipal and other sub-national mobility control policies are diverse and span across a range of different fields of intervention, from social affairs and labour regulations to public order policing (see also Fauser, 2019). A common feature of most, if not all, such policies is that they target different aspects of people's everyday life. They are part of the complex bordering practices that 'follow people around and surround them as they try to access paid labour, welfare benefits, health, labour protections, education, civil associations, and justice' (Anderson, Sharma, \& Wright, 2009 , p. 6). Per defintion, they also rely on indirect measures. As K-Sue Park (2019) emphasises, they are characteristically policies of 'selfdeportation' insofar as they seek to 'make individuals into agents of the state's goal of their removal by making their lives unbearable' (p. 1882). Notably, municipal and sub-national mobility controls often rely on 
spatial tactics: on the use of space as a strategy and technique of power and control (Low \& Lawrence-Zúñiga, 2003, p. 30; see also Zick, 2006). To give just one example, some U.S. cities are strategically using public space ordinances to close down day labour hiring sites for the stated purpose of creating an inhospitable environment for undocumented residents who rely on the infrastructure of such sites to secure work (see Varsanyi, 2008). As I will suggest, this reliance on indirect and spatial tactics is reflective of a more general feature of urban regulations, namely the fact that they generally tend to avoid governing through categories of 'person' and 'status'. When they govern people, they do so by governing space (Valverde, 2005, 2009a, 2009b).

Notably, municipal and other sub-national mobility control policies need not be exclusionary. There are many examples of cities and sub-national levels of government that have adopted measures that run in the opposite direction, towards protecting irregular migrants against immigration law enforcement. The sanctuary cities movement is a case in point. With some success, this movement has lobbied local governments on both sides of the North Atlantic to limit cooperation with national-level immigration authorities and challenge state-defined 'migrant illegality' (see Bauder, 2017). In the United States, a growing number of cities are actively and openly opposing the Trump administration's anti-immigration policies, including the controversial 2017 'Muslim travel ban', causing much controversy and debate (see Pengelly, 2019). Several North American cities have also passed sanctuary ordinances that extend access to municipal services to undocumented migrants and prevent city employees from questioning clients about their immigration status (McDonald, 2012; Nyers, 2010). Similar policies have been implemented in a number of European cities (Bagelman, 2013, 2016; Lundberg \& Strange, 2017; Squire \& Darling, 2013). Notably, the City of Malmö has taken some steps towards implementing sanctuary ordinances. The public library has opened up to undocumented residents (Lundberg \& Dahlquist, 2018). In 2014, the city also adopted guidelines that affirm the right of 
undocumented migrants to seek means-tested social assistance (Nordling, 2012, 2017). ${ }^{20}$

Whether exclusionary or inclusionary, the practices of sub-national and urban mobility control are difficult to comprehend within the established categories and frameworks of migration scholarship. In migration studies, it is common to distinguish between immigration and integration policy, a dichotomy which assumes a neat separation between the inside and outside of the state. While immigration policy - typically defined as policy related to the admission, entry, exclusion, and expulsion of noncitizens from state territory - is assumed to take place at the outer edges of the state, integration policy is generally treated as an 'internal' affair (Bosniak, 2006; Sainsbury, 2006). Sub-national and urban mobility controls blur this conventional distinction between immigration and integration policy, thus necessitating a rethinking of the taken-for-granted categories and concepts of mainstream migration scholarship.

From the point of view of contemporary constitutional law and theory, municipal or otherwise sub-national immigration control policy should also be an impossibility. In Sweden, as in most formally sovereign states, border and immigration control is primarily, although not exclusively, the authority of the national state. As a member of the EU, Sweden is also an active participant in a supra-national regime of border and mobility management (Bigo, 2008; Guild \& Bigo, 2010; Walters, 2002b). However, the two sub-national levels of government - the municipal and regional governments - have no direct powers to control who comes and goes or how they do it. As Ien Ang (2006) notes, a city 'cannot, generally, declare the closure of its borders' (p. 32). To better understand the shifting relationship between cities and states in the context of contemporary urban bordering practices, it is useful to consider theories of scale.

\footnotetext{
${ }^{20}$ These guidelines have since been revised. I discuss this in more detail in chapter seven.
} 


\section{Theories of Scale and Re-scaling}

Scale is a core concept within the entire discipline of geography, though it is conceptualised and utilised in a variety of different ways. A basic definition of the term, found in the 1994 edition of The Dictionary of Human Geography, states that it is a 'level of representation' (Johnson et al., cited in Marston, 2000, p. 220). Within the sub-discipline of physical geography, it is usually treated as a metric for representing spatial relationships. It is common to distinguish between geographic scale, which refers to the spatial extent and dimensions of a given phenomenon (i.e., its size), and operational scale, which refers to the level at which a given process operates and at which it is appropriate and relevant to observe it. Cartographic scale is the ratio between a distance on a map and the corresponding distance 'on the ground', on the earth's surface. Among critically-oriented human geographers, the meaning of scale has been the topic of much conceptual and methodological debate. While it is generally understood on the basis of a constructivist ontology to be a socially constructed category, there have been significant disagreements about what factors and processes contribute most significantly to the construction of scale. These debates mirror broader disagreements between orthodox Marxist- and more post-structurally inclined geographers: while some have argued for a view of scale that foregrounds the structural dynamics of capitalist production, others have instead emphasised the gendered and racialised relations of social reproduction (see the Marston/Brenner debate, Brenner, 2001; Marston, 2000; Marston $\&$ Smith, 2001; Purcell, 2003). Following Adam Moore (2008), I adopt a view of scale as an ordering epistemology - a 'category of practice' that structures and constrains our ways of seeing, thinking, and acting. Thus, rather than treating scale as 'a thing in the world' (i.e., an ontological category), I seek to trace the ways that scalar categorisations are put to work and made 'real' and how this structures socio-political processes and relations (see also Blomley, 2013).

The notion of scale allows me to approach the familiar categories 'local', 'regional', 'national', and 'global' as historically-specific, and ultimately temporary, geographic representations and materialisations of social 
relations. Here, the emphasis on materialisations is important. Again, scale is not purely symbolic but an ordering device that is real (or rather, made real) in the sense that it has concrete material effects and consequences. While my use of 'scale' foregrounds its legal and political construction, I am nevertheless influenced by both the Marxist and poststructuralist streams of theory and research on scale. In particular, I make extensive use of the concept of re-scaling, which refers to the "[disruption] of fixed notions of territorially bounded political units' and the qualitative transformation of the hierarchy of authority and power between institutions variously positioned and described as urban, regional, national, and global, respectively (Glick Schiller \& Çağlar, 2011, p.5).

In the early 1990s, scholars of political economy within and beyond the discipline of human geography seized the concept of scale to make sense of the restructuring of the capitalist world economy and the advent of 'neoliberal globalisation', following the economic crisis of the 1970s. Starting from the observation that the local, regional, national, and global had become (and were becoming) increasingly intertwined, one of their objectives was to understand the shifting role and status of the nationstate in the context of globalisation. To give just one example, Neil Brenner (1997) argued across a series of articles that globalisation requires a significant re-organisation and re-territorialising of the world economy and that this is, in fact, accomplished through state activity, rather than against states. Globalisation, Brenner (1997) emphasised, should therefore be understood not as an 'mono-directional implosion of global forces into sub-global realms' but as a process in which the state plays a central role as it attempts variously to organise and regulate the spaces of the increasingly globalised economy (p. 159; see also Swyngedouw, 1996). The reconfiguration of mobility controls can be understood as being thoroughly intertwined with these processes. Further, the entire project of EU integration can be thought of as revolving around the re-scaling of state powers across a wide range of policy fields, including mobility control policy. While there is a widespread assumption (evident in popular discourse as well as in research) that this has been a one-directional process, with powers being displaced from the national 
states to Brussels, the EU is in fact a more complex scalar organisation (see Iossa, 2017).

In political and socio-legal studies, the concept of scale has been used by Nancy Fraser. In her book Scales of Justice (2009), she invokes the double meaning of the term 'scale' to make an argument about the changing conditions for social-justice-oriented political mobilisation and struggle in light of globalisation. As she uses the term, scale is both a measure of balance and a metric for representing spatial relationships. The former concerns the 'what' of justice - that is, what counts as a matter of justice? Fraser (2009) famously defines three dimensions of justice: redistribution, recognition, and representation. As a geographic metric, scale stands for the 'problematic of framing' - that is, who counts as the subject of justice and what should delimit the bounds of justice? This then concerns the 'who' of justice. Say we agree on a politics of re-distribution, at what scale should this take place and who should be involved - the national/territorialised citizenry, global humanity, the local community, 'those who are here' (cf. Bosniak, 2007), communities of risk, or the worker-citizen? These types of questions are, as I will show, central to the debates on 'vulnerable EU citizens' in Sweden.

One of Fraser's (2009) arguments is that globalisation, broadly defined, has destabilised the political imaginary of the post-war period, which she defines as 'the Westphalian-Keynesian conception of justice'. In short, this is the idea that economic and social justice is to be achieved through re-distribution between citizens within the national state. This imaginary is closely related to welfare nationalism (Keskinen, 2016; Koefoed \& Simonsen, 2007), and it features prominently in the debate on 'vulnerable EU citizens', who are frequently constructed as properly belonging somewhere else or as an issue for their home-countries or the EU to 'deal with'. Fraser's concept of scale is useful to me in that it makes visible the spatial dimensions of the problematisation of 'vulnerable EU citizens'. But I am also interested in how scalar dynamics shape government in a more practical sense. For this, I have found the work of socio-legal scholars Boaventura de Sousa Santos and Mariana Valverde particularly helpful. Their use of scale foregrounds the relationship between the scalar 
representation and allocation of issues and how this shapes (legal) governance.

\section{Games of Scale and Jurisdiction}

Boaventura de Sousa Santos (1987) treats cartographic scale as a 'literal metaphor' for the workings of law. His analysis revolves around interlegality - a concept which Santos uses to identify the co-existence and interplay between multiple legal orders in the same social space. Santos' key argument is that different types of legislation, much like maps, represent the 'real' social world at different scales, thus emphasizing different features and relationships. For example, human rights law is a 'small-scale legality', characterised by big overarching principles and few details, while public order ordinances and other urban laws are 'big-scale legalities' in the sense that they regulate very specific activities in great detail. Given that there are always multiple and often competing laws that govern the same thing, legal practice ends up turning on conflicts over which 'map' to use.

Mariana Valverde elaborates on de Sousa Santos conception of scale and develops a framework for understanding the joint workings of scale and jurisdiction in legal governance. For Valverde (2009a), choices and conflicts over which legal 'map' to use is a 'game of jurisdiction' or scale. ${ }^{21}$ This is a fundamentally political game, but it is often not thought of as such. Valverde (2009a, 2010) starts from the observation that there are important qualitative differences in how governance is done at different scales (local, regional, national, and supra-national). Urban municipal authorities govern things through different means (instruments) and based on different rationalities than national governments/authorities do. According to Valverde (2016), '[i]t is very important, when looking at practices of local policing, to remember that

\footnotetext{
${ }^{21}$ Jurisdiction, here, denotes the official power to make legal decision and judgments. It asks, which law is authoritative in a given locality and situation, and correspondingly where an issue to be addressed and by whom (Blomley, 2013, p. 3). According to Valverde (2009a, 2015), it can be described, from a socio-legal point of view, as 'the governance of legal governance'.
} 
local government is not a smaller sovereign. It does not merely have fewer powers than the sovereign; it has different powers'. While criminal sanctions and migration control are two 'fundamental and jeleaously guarded perorgative of central government sovereignty', local government has unique powers to regulate and impose controls on the 'time, place, and manner' of a broad range activities in and uses of space (p. 49).

A key idea that I take from Valverde is that differences and even incommensurabilities between different legal orders (human rights and public order law, for example) can be functional to government actors and others, who can (sometimes) strategically shift (jump scales) from one scale of governance or jurisdiction to another. Indeed, Valverde (2010) makes the case that scalar differentiation can be mobilised in a more or less strategic manner (i.e., through a game of scale/jurisdiction) to achieve certain aims. She gives two examples of this that are highly pertinent to my research:

A government that cannot, for constitutional reasons, recriminalize the status of vagrancy may well encourage a variety of officials and/or police to govern disorder at a highly local scale by providing them with new coercive tools that govern space and persons in a sitespecific manner.

A national government that is unable to pass new criminal laws targeting a status can easily shift scales and enable municipalities to take a host of measures that have a similar effect. (2010, p. 235)

Elsewhere, she also discusses how sanctuary ordinances are made possible through a scalar differentiation between local-level law and national-level immigration law and policy (Valverde, 2016).

A crucial aspect of the intertwined games of scale and jurisdiction is that they often work almost 'as if by magic' to determine how a certain phenomenon or population is to be governed, because once a particular phenomenon has been allocated to a particular scale or jurisdiction, it often appears suited to a particular form of governance (Valverde, 2010, p. 236). As jurisdiction separates and sorts different phenomena and 
organises the where (i.e., within which territory or in relation to which function) and the who (i.e., by which authority) of governance, the games of scale and jurisdiction tend to determine - often implicitly, without much political discussion and deliberation - as what kind of legal object and therefore also how a particular phenomenon is to be governed (Valverde, 2009, p. 144).

[G]overning projects and the power-knowledges that make them work are differentiated from one another and kept from overtly clashing by the workings of the machinery of 'jurisdiction', which instantly sorts governance processes, knowledges, and powers into their proper slots as if by magic, and sets up a chain by which (most of the time) deciding who governs where effectively decides how governance will happen. (Valverde, 2009, p. 145)

\section{The Urban as a Scale of Mobility Control}

The games of scale and jurisdiction, Valverde argues, have the effect of turning thorny political questions into seemingly neutral and technical matters. Thus, Valverde (2010) suggests that 'researchers seeking to illuminate the networked policing of [migrants] could advance by asking questions about scale, and about the related but not coterminous legal mechanism of jurisdiction' (p. 216). I would like to follow up on this suggestion and consider the urban as a specific sort of legal and political space and, therefore, a specific scale of mobility control. In particular, I want to highlight some contrasting conceptualisations of the urban that are relevant to understand my case study.

\section{The City as a Lived Space}

One way of seeing cities that has bearing on my study is that they are somehow more immediate, material, and therefore more 'real' than other scalar-constructs. This idea is expressed by Engin Isin (2007), who argues that while the state exists only as a virtual entity (symbolic, imaginary, ideal) the city is defined by being both a virtual and an actual (physical, material) space:

The city is actual in the sense that once it comes into being it is permanent (until it is destroyed completely it maintains its capacity to 
exist), solid and enduring, even when it is transformed. The actual city embodies things (buildings, roads, infrastructure, uses) as well as bodies within intrinsically related and proximate arrangements that constitute its physicality and materiality. The actual city is urbs. The city is also virtual in the sense that it is an association that exists beyond the actual bodies and things that constitute it. The virtual city is civitas. (pp. 211-212)

Similarly, Ien Ang (2006) suggests that the defining quality of the city is that it is a 'lived physical and social space' unlike the nation which she argues, is an abstract entity - an 'imagined community' (p.33). ${ }^{22}$ In Ang's (2006) own words, 'what distinguishes the city from the nation as imaginary constructs is that the former is much more defined by the dynamic concreteness of life in the city as a space - or more precisely, as a multiplicity of spaces - of dwelling, work, travel and play' (p. 33). This concreteness of urban life is one way to explain why conflicts over belonging and membership so often become heightened in cities. Isin (2007) notes, 'the bodies social' of cities, states, and nations never actually coincides with their corresponding 'body politics' as instituted in law (p. 219); there will always be people present making explicit claims to belonging (or just living out their lives) who are not formally included as members of a given political institution. Because of the concrete and experiential quality of cities and urban spaces, the exclusions and inclusions of constructs such as citizenship become visible here.

Helena Holgersson's (2011) work on the urban geographies of noncitizenship illustrates this last point. Based on ethnographic fieldwork with undocumented migrants in Göteborg, Sweden, Holgersson (2011) argues that the exclusion from formal citizenship that defines the condition of undocumentedness is concretised in the city as a fear of moving about the city, for example (see also De Genova, 2002). At the same time, the simple binary between inclusion and exclusion breaks down in the city: By inhabiting the city in various ways (including by

\footnotetext{
${ }^{22}$ Similarly, in much of the political economy literature, the city is also regarded as the scale of experience (see, for example, Taylor, 1982).
} 
moving about it even though one is afraid to do so), undocumented persons (who are non-citizens in a juridico-legal sense) are sometimes able to gradually constitute themselves as citizens in a cultural and social sense.

Related to the vision of the city as more real, there is a longstanding association between the city and notions of inclusion and freedom. Compared to the nation-state, which is commonly regarded as an exclusive and exclusionary 'imagined community', the city is seen as the site of lived diversity and therefore as more inclusive Such an understanding of the city as more inclusive than the nation comes through in Koefoed and Simonsen's (2011) analysis of experiences of belonging as 'strangers' in Copenhagen, where they argue that it is easier to become a Copenhagener than to become a Dane. The idea of the city as a site of inclusion is contrasted by the idea of the city as the pre-eminent site of police power.

\section{The City as a Space of Police Power}

The idea of the urban scale as more 'real' and therefore more inclusive than the national scale contrasts with the conceptualisation of the city as a pre-eminent space of police power. To understand what is specific about municipal mobility controls, we need to consider what cities (qua municipalities) govern more generally and how (i.e., with what instruments) they do so. One way to begin to answer this question is to note, as Mariana Valverde $(2005,2009$ a, 2011) does, that specific forms of law and legal knowledges are operative at the urban scale. Municipal governments, in particular, are limited in the means they are afforded to attend to various issues. Apart from budgetary decisions and tax policies, planning, nuisance, and public order laws are some of the only legal frameworks available to municipal governments. In other words, the predominant forms of law that are available to those who operate within the urban scale are planning, nuisance, and public order law. ${ }^{23}$ This means

\footnotetext{
${ }^{23}$ Mariana Valverde (2005) uses the umberella term 'municipal law' to denote these types of law. She bases this on studies of North American municipal law (primarily Canadian, but also to some extent U.S. American
} 
that thorny political issues, when allocated to the municipal level, tend to be funnelled into these legal frameworks (Ranasinghe \& Valverde, 2006; Valverde, 2005). According to Valverde (2005, 2009a), urban law is distinct in two interrelated respects: first, in that it rests on the logics of 'the police' or 'police power'; second, in that it tends to work through categories of space, activities, and uses rather than through categories of space. Indeed, municipal authorities often govern, or attempt to govern, people through space.

In this context, 'police' refers not to the institution of the police force. Rather, 'police' is defined as a particular rationality, distinct from liberal law and political rationality, that is essentially concerned with the ordering of society. William Walters (2015) defines 'police' as a set of pre-liberal 'historical knowledges and practices dedicated to ordering society' (p. 13). According to Valverde (2009), police power evolved in tandem with European urbanisation to ameliorate the social conflicts and problems that this brought about (p. 148). As Foucault himself puts it, police is the precondition of the urban: 'to police and to urbanize are the same thing' (as cited in Valverde, 2009, p. 148). In a similar vein, Mark Neocleous (2000) uses the term to refer to 'the regulation of the internal life of a community to promote general welfare and the condition of good order' (p. 1; see also Foucault, 2007).$^{24}$ Given the emphasis on order, police power is essentially conservative of the status quo. This is what

\footnotetext{
law), where, as I understand it, municipal law refers first and foremost to planning, zoning, nuisance, and public order law. Here, I have replaced the term instead with the term 'urban law'. This is to avoid any confusion with the Swedish Local Government Act (Kommunallagen), a specific act which regulates the municipalities and the counties in terms of their internal organisation and responsibilities.

${ }^{24}$ This defintion of police power, as I understand it, is different from (although related to) Jacques Rancière's notion of 'the police'. According to Dikeç (2007) [who I am relying on for my understanding of Rancière's philosophy], Rancière defines 'the police', in a broad sense, as 'all the activities which create order by distributing places, names, functions (Rancière, 1994, p. 173, cited in Dikeç, 2007, p. 18). This, Dikeç contends, is always and necessarily a contested process, which never achieves complete closure. Dikeç furthermore stresses that the police is both a 'principle of distribution' and 'an apparatus of administration', which, in turn, rests on a particular regime of representation. While 'the police' refers to the established order of things, 'politics' signifies that which disrupts this order (Dikeç, 2007, pp. 18-21). I understand Rancière's concept of 'the police' to be more open-ended than the rather specific rationality that I have in mind here.
} 
Dikeç (2007), following Jacques Rancière, argues sets it apart from politics proper (p. 20-21). In the words of Uitermark and Nicholls (2014),

Policing is the opposite of politicizing as it aims to neutralize and preempt challenges to the legal and social order. Historically, the concept of policing has a broad meaning and refers to the range of governmental technologies, rationalities and arrangements - partly centrally orchestrated, partly self-organized locally - developed to align subjects with the state. (p. 1)

How then is police distinct from liberal law and notions of justice? Dubber (2005) suggests that the following distinction can be drawn between liberal law and the pre-liberal rationality of police power:

From the perspective of [liberal] law, the state is the institutional manifestation of a political community of free and equal persons. The function of the law state is to manifest and protect the autonomy of its constituents.... From the perspective of police, the state is the institutional manifestation of a household. The police state, as paterfamilias, seeks to maximize the welfare of his - or rather its household. ${ }^{25}$ (p. 3)

Based on an analysis of the Seattle Municipal Code, Blomley (2012) suggests that 'police' is 'powerfully evident in cities' - manifest in urban law, including in such local ordinances as the Settle Municipal Code (p. 919). Blomley (2012) identifies five distinctive characteristics of urban law and police powers. First, the objects of urban law are diverse and widespread; they range from the behaviours of persons to the arrangement of inanimate things in public space. In the case of the Seattle Municipal Code, '[p]otbelly pigs, shared drinking cups, hazardous vegetation, grain elevators, owners of tattoo parlors, and street users are caught up in a promiscuous and seemingly unconnected series of constraints and compulsions' (p. 918). Second, urban law tends to be simultaneously highly specific and highly general: it might prescribe exactly where and for how long street buskers are allowed to play music, while also

\footnotetext{
${ }^{25}$ This resonates with what William Walters has called 'domopolitics' - a political rationality centred on the image of the state as home (Walters, 2004).
} 
including provisions on such elastic and unquantifiable notions as 'nuisance' or 'obstruction'. Third, urban law is - crucially - forwardlooking, aimed at the prevention of potential hazards and wrongdoings. This sets it apart from, for example, criminal law, which is oriented towards retroactive resolution and punishment. Broadly speaking, urban law regulates situations of disorder rather than crime. Accordingly, urban police powers tend to be discretionary, open-ended, and sweeping in their reach. Finally, urban law rarely serves the direct and immediate interests of private individuals. Rather, it is designed to protect and uphold order within a broadly defined collective, the public. ${ }^{26}$

Just as the mechanisms of urban law and police power are spatial, so too are their effects. Waldron (1991) notes in a seminal article that 'everything that is done has to be done somewhere'. As such, he argues, 'no one is free to perform an action unless there is somewhere he is free to perform it' (p. 296, my emphasis). Accordingly, urban laws that prescribe and regulate how one is allowed to use and behave in public space - while often phrased in impartial terms - function to systematically eliminate and restrict the spaces in that homeless individuals depend on to carry out their daily routines and fulfil their basic needs. Their effects are therefore violent. Indeed, Mitchell (1997) even goes so far as to call them potentially genocidal (p. 312). While Waldron (1991) does not use such powerful language, he maintains that rules against performing an act in public place 'amounts in effect to a comprehensive ban on that action so far as the homeless are concerned' (p. 318), thus undermining their basic freedom:

For a person who has no home, and has no expectation of being allowed into something like a private office building or a restaurant, prohibitions on things like sleeping that apply particularly to public places pose a special problem. For although there is no general prohibition on acts of these types, still they are effectively ruled out altogether for anyone who is homeless and who has no shelter to go to. The prohibition is comprehensive in effect because of the

\footnotetext{
${ }^{26}$ That is not to say that it affords uniform protections to all members of the public.
} 
cumulation, in the case of the homeless, of a number of different bans, differently imposed (p. 315).

Mitchell and Heynen (2009) use the term 'geographies of survival' to denote the legal and social geographies that makes it possible - or nearly impossible - to 'inhabit and make a life in the city' (p. 315). They note that for very poor people, such as the homeless, the geography of survival is typically ' $k$ nitted together into a network of public and private spaces and social services', essential to their day-to-day survival (p. 611). I use this concept in the analysis to describe the cumulative unmaking of the infrastructures and spaces that people categorised as 'vulnerable EU citizens' use to sleep, eat, socialise, organise, and so on.

\section{Urban Mobility Controls in an Historical Perspective}

While people have always moved, they have not always migrated (Bosma, Kessler, \& Lucassen, 2013; Lucassen, 2018). The category of 'migration' - defined, as it commonly is, as movement across stateborders - is a product of the modern state and state system. The very word 'immigration' is, in fact, a 19th century invention (Shumsky, 2008). If today immigration policy is generally the authority of formally sovereign national states, this is a conditional and historical achievement. The centralised national state is a relatively recent manifestation of state power (Foucault, 2007), and it has not always held the right to authorise and regulate people's movements and (political) memberships. Historically speaking, cities have instead been some of the most thickly bordered polities (Isin, 2007; Lucassen, 2012). Thinking historically about mobility control, and about mobility more generally, allows us to better grasp the irreducible yet continuously changing relationship between the regulation of mobility and the constitution of the state (cf. argument in De Genova, 2007, p. 425). It serves to de-naturalise the association of borders with the nation-state and bring attention to the ways in which local government institutions (like cities, towns, and rural church parishes) have historically sought to regulate the mobilities of unwanted groups by attempting to keep them out. A detailed historical analysis is obviously far beyond the scope of this thesis. My goal in this section is simply to point to some of the roots of contemporary practices of urban 
mobility controls. In doing so, I also want to highlight the longstanding connection between the politics and practices of mobility control and the stigmatisation and racialisation of Roma and Traveller groups.

In Europe, poor people on the move have been problematised as a source of insecurity and subjected to government controls since at least the late medieval period, when the gradual breakdown of feudal society and the enclosure of common lands mobilised formerly bonded tenants (Beier, 1985; Ocobock, 2009; Torpey, 1998, 2000). Medieval feudal society was characterised by a rigid and hierarchical socio-spatial order, where everyone quite literally knew their place. Mobility, for the great majority of people, was not only forbidden but also widely feared: to be mobile was to be 'without a place', condemned either to excommunication or to exile (Mumford as cited in Cresswell, 2011, p. 11). The appearance of destitute 'masterless and rootless men' at the tail-end of the medieval era brought about a crisis of power and social order, prompting a search for new forms of mobility control (Bauman, 1987; Beier, 1985; Lucassen, 1998, 2012). As more and more landless people across Western Europe set out for the towns and cities, the rapidly urbanising centres - unable or unwilling to assimilate their 'immigrants' - began to impose restrictions on settlement, specifically targeting the mobile poor. In short, they made them into vagrants (Anderson, 2013, pp. 16-20; Beier, 1985). Crucially, the first mentions of variously labelled Roma and Traveller groups in official records, both in Sweden and elsewhere in Western Europe, dates back to this period (Montesino, 2002, pp. 34-38).

The breakdown of feudal society is commonly taken to mark the beginning of the centuries-long processes whereby the modern state came into being through the successful monopolisation not only of the legitimate authority to extract taxes and use violence but also of the powers to authorise and regulate mobility (Bauman, 1987; Beier, 1985). Historian John Torpey $(1998,2000)$ has famously referred to this process as the state's gradual 'monopolization of the legitimate means of movement' (1998, p. 240). Torpey's argument is that the modern state and state system has expropriated and monopolised the authority to determine who may circulate within and across state borders. Over the 
course of several centuries, the European states gradually stripped private entities (most notably, the feudal landlords) of their powers to forbid and otherwise control the movement of people and 'gathered [these powers] into their own hands' (Torpey, 1998, p. 241). ${ }^{27}$ This was an essential aspect of the transition from feudalism to capitalism. It signalled the withering away of the institutions of serfdom and vassalage and helped facilitate the subsequent proletarianisation of the poor (see also, Anderson, 2013, p. 14). As Torpey (1998) emphasises, the state's monopolisation of the legitimate means of movement closely followed the consolidation of the European national states and the forging of the modern Westphalian state system out of 'the panoply of empires and smaller city-states and principalities that dotted the map of early modern Europe' ( p. 242; see also Tilly \& Blockmans, 1994). It reflected an overall re-scaling of government - a 'shift in orientations' from the scale of the city and local community to the scale of the national state (see also Isin, 2007). Further, as I will discuss in more detail below, it paralleled the development and re-scaling of the poor relief system.

\section{The Early Modern 'Sandwich Formula' of Poor and Vagrancy Laws}

Crucially, the state's monopolisation of the legitimate means of movement was far from a linear process, nor was it achieved overnight. Throughout the early modern period (roughly the 1500s-1800s) and into the 20th century, people's movements continued to mostly be regulated at the local-level through a 'sandwich formula' (Lucassen, 1998) of compulsory work edicts and poor and vagrancy laws. In a nutshell, this formula sought to achieve the disciplining and sedentarisation of the workforce and, at the same time, ensure the protection of cities, towns,

\footnotetext{
${ }^{27}$ Crucially, the state's monopolisation of the legitimate means of movement did not just bolster the state's powers: it helped constitute the modern state. Echoing Foucault's (2007) thesis on the governmentalisation of the state, Torpey (1998) emphasises that the modern state did not simply seize the means to regulate movement. Rather, the progressive consolidation of authority through the harnessing of governmental technologies for regulating movement (e.g., the passport) contributed (and continues to contribute) to 'constituting the very "state-ness" of states' (p. 240).
} 
and rural church parishes against the influx of people likely to become a charge on the poor rate.

As Finnish historian Miika Tervonen (2010) emphasises, the history of Roma and Traveller groups in the Nordic (including in Sweden) is thoroughly intertwined with the historical development of poor and vagrancy laws and local-level social control measures - so much so that it is unintelligible outside of this context (cf. Lucassen, 1998; Montesino, 2002). ${ }^{28}$ For centuries, so-called tattare and zigenar $^{29}$ were considered a 'class of permanent vagrants', a sub-group of the overall vagrant population. As such, they were targeted by many of the same regulations and coercive practices that sought to force the idle and wandering poor into agricultural labour or military service, like the Swedish compulsory service statues (Sw: försvarslöshetssystemet) (Johansson, 2016; Montesino, 2002; Tervonen, 2010). At the same time, the people labelled as tattare and zigenare were generally considered by the elites to be morally degenerate, unchristian foreigners, and thus a threat to public morality and order.

The 1600s to 1800 s witnessed the adoption of multiple successive ethnically-based expulsion decrees specifically targeting zigenare. ${ }^{30}$

\footnotetext{
${ }^{28}$ Leo Lucassen and the other members of the Dutch school of social history have made the same argument about gypsies in Western Europe (Lucassen, 1998; Lucassen, Willems, \& Cottaar, 1998).

${ }^{29}$ Zigenare is a pejorative term used to refer to individuals and groups of Romani origin. A direct translation of the German term zigeuner, it is thought to have derived from the Byzantine Greek word $\tau \sigma \iota \gamma \gamma$ ávo [tsingános], which literally means 'untouchable'. The word carries similar offensive connotations to the English word 'gypsy'. Historically, the term zigenare has been used interchangeably with the term tattare. This changed in the late 1800 s, when several groups of Romani origin immigrated to Sweden from elsewhere in Europe (in particular from Eastern Europe and Russia); the term zigenare came to denote the newly arrived groups, while the term tattare was reserved for travelling families who had lived in Sweden for generations. Today, the term zignerare is generally understood to be an earlier and offensive term to describe Roma, while tattare is understood to be roughly synonymous with Travellers (Sw: resande).

${ }^{30}$ For example, in 1637 the Swedish state infamously issued a decree ordering all 'sikeiner or tartare' to leave the country within the next three months or face either death penalty by hanging (for men) or expulsion (for women and children). There is no evidence that anyone was ever actually executed on the basis of this specific decree. However, expulsions appear to have been recurrent throughout the time period (Minken, 2009; Montesino, 2002; Tervonen, 2010, p. 35).
} 
These national-level expulsions decrees were notoriously difficult to enforce, especially in the vast, densely forested and weakly controlled border regions of the Nordic countries. Tervonen (2010) suggests that, from the point of view of everyday life experience, the principal borders that mattered for so-called tattare, zigenare, and other itinerant or 'loose people' (Sw: löst folk) living in Sweden in the early modern era were not those of the territorial state but those of towns, local Church parishes, and later, municipalities (pp.41-45; see also Aronsson, 1992). The two main border agents at the local-level were the county sheriffs (Sw: länsmän), who held the power to send people away if they deemed them to be vagrants, and the parish priests, who controlled the local population registries and could issue 'internal passports' ( $\mathrm{Sw}$ : inrikes pass). Behind these two gatekeepers were the local elites - landowners and other wealthy ratepayers.

Indeed, an important source for the desire to keep 'loose people' out came from the communal obligation to care for the poor and needy. Well into the 20th century, poor relief was administered at the level of the local Church parish, which would levy taxes from its better off inhabitants and use these to administer alms. Given that the parishes were often quite small (limited, in some cases, to a couple of hundred members), the recipients of poor relief were intimately tied to their benefactors (i.e., local ratepayers, the elites), who both financed the system and set its rules (Aronsson, 1992; Ekström von Essen, 2003, pp. 33-61). The local ratepayers, on their part, had a direct vested interest in preventing the settlement of individuals and families who they thought might become a burden on the local poor relief funds. The historian Peter Aronsson (1992) therefore suggests that many Swedish municipalities, well into the 19th century, essentially functioned like 'small states' with hard outer borders to the 'dangerous, poor, grey mass' that supposedly 'threatened to invade them' (p. 222, my translation).

Focusing on the decades before and after the turn of the 20th century, historian Martin Ericsson (2015) shows that many municipalities in the south of Sweden practiced a form of 'territorial exclusion' (i.e., local bordering), targeting individuals and families who they identified as 
tattare. For example, some municipalities prohibited property owners from renting or selling to so-called tattare. It also happened that local authorities would buy up properties for the sole purpose of preventing certain families from moving in. Historical records also show that some municipalities purchased boat tickets for individuals and families who they considered to be tattare so as to facilitate their emigration from the country altogether (further details and sources in Ericsson, 2015, pp. 4851,61-82). The cumulative effect of these practices was to create a 'spiral of exclusion', where people were continuously shuffled from one municipality to another with no end in sight (Ericsson, 2015, p. 68).

\section{The Nationalisation of Bordering Practices}

Concomitant with the rise of industrialism, the poor relief system in Sweden (as in much of Western Europe) was gradually nationalised and subsequently supplemented by a variety of other social security and aid measures. In tandem with these processes, mobility controls were rescaled to the national level, contributing to the establishment of the national biopolitical border. Torpey (1998) summarises this development as follows:

As European states declined in number, grew in size, and fostered large-scale markets for wage labor outside the reach of landowners and against the traditional constraints imposed by localities, the provision of poor relief also moved from the local to the national arena. These processes, in turn, helped to expand 'outwards' to the 'national' borders the areas in which persons could expect to move without authorisation. Eventually, the principal boundaries that counted were those not of municipalities, but of nation-states. (pp. 242-243)

In other words, the rescaling of the poor relief system, and the subsequent emergence of the welfare state system, brought about a re-purposing of the instruments of expulsion that had previously been used to regulate the mobilities of the poor between cities and villages. These were now instead harnessed to defend and promote the prosperity and welfare of a nationally-defined population. As part and parcel of these processes, the 'social threat' of vagrancy was also redefined along nationalist lines, and 
a new category of vagrants emerged: the mobile poor foreigner. In Sweden, a series of regulations on entry were implemented towards the end of the 1800s that required foreigners wishing to enter the country to show proof of employment and empowered the authorities to expel foreigners deemed to be a burden on the poor relief system (Montesino, 2002, p. 95). In 1914, in connection with the outbreak of the First World War, the Swedish Parliament also adopted the country's first comprehensive Aliens Act. Notably, this included an entry ban, designed specifically to keep so-called zigenare out of the country. ${ }^{31}$

\section{Racialised Bordering Practices in the 20th Century}

The nationalisation of the border did not completely do away with local level bordering practices. Municipal and other government actors continued to engage in exclusionary mobility control practices long after the poor relief system was nationalised and subsequently replaced by comprehensive welfare policies. However, the mechanisms and rationalities of differentiation and exclusion underpinning such practices changed significantly with consolidation of the nation-state. In the poor relief system, the two salient distinctions were 1) the one between the deserving and undeserving poor and 2) the one between the local poor and their wayfaring counterparts. With the emergence of the national biopolitical state, these distinctions were both rearticulated in moral terms and along ethnic and racial lines. The redefinition and gradual differentiation of vagrancy statuses during the first three decades of the 20th century illustrate this shift.

\footnotetext{
${ }^{31}$ The entry ban effectively targeted a group of families who had immigrated to Sweden at the turn of the centuries, the grandparents and great-grandparents of the community that is nowadays known as the Swedish Roma (Montesino, 2002, p. 98). The entry ban remained in effect until 1954 and was arguably genocidal - if not by intention so at least in terms of its effects. It functioned during the Porajmos to prevent individuals and groups who were targeted by the extermination policies of Nazi Germany from seeking refuge in Sweden (DS 2014:8, pp. 142-155). Paradoxically, it also had the effect of keeping stateless so-called zigenare, who could not count on being able to return should they decided cross the border, locked into the territory of the Swedish state.
} 
Indeed, the gradual centralisation and rationalisation of the poor relief system and the rise of industrial capitalism combined prompted a remaking of the category of vagrancy and an attendant shift in the government of Roma and Traveller groups. In simple terms, vagrancy went from being defined as a problem of idleness, to which the solution was compulsory work, to being characterised as a problem of anti-social and deviant behaviour - a problem which instead seemed to call for a moral reform of the individual (Edman, 2008; Wallentin, 1989). This paved the way for the renewed classification and stigmatisation of tattare and zigenare. Over the course of the first two decades of the 20th century, attempts to revise and rationalise the Swedish Vagrancy Act (Lösdriverilagen, first adopted in 1885) prompted an intensive search for a diagnosis of what came to be defined as 'the tattare question' and the 'the zigenare question', respectively (Montesino, 2002; Ohlsson Al Fakir, 2015).

In 1907, the government appointed a committee - the Committee on the Poor Relief Act - to review and propose amendments to the Vagrancy Act and make suggestions for how to further rationalise the poor relief system. The committee consisted of members of the fattigvairdsfolket ('the-poorrelief-people'), a close-knit network of liberal-minded social advocates and policymakers. Their shared political project was guided by a belief that the problem of poverty was fundamentally rooted in the individual traits and moral shortcomings of the poor themselves (Lundquist as cited in Ericsson, 2015, p. 108). Thus, they believed that social policy should aim to educate the poor and to instil in them a strong work-ethic. The committee took upon themselves to map the vagrant population to identify subgroups and propose targeted interventions aimed at assimilating them into the system of wage labour.

Influenced by the scientific racism of their time, the committee identified tattare and zigenare as separate ethno-racial groups, distinct from one another as well as from the overall vagrant population. The former was defined as a people of 'mixed race' who led an itinerant lifestyle, the latter as a 'pure race' of immigrant origin. Ultimately, the committee proposed that tattare should be assimilated into the settled workforce. This was to 
be achieved mainly by criminalising their traditional trades (horse trade, traveling funfairs, and fortune telling) and by eliminating their camps and settlement. ${ }^{32}$

Meanwhile, the committee described zigenare as strangers whose nomadic and foreign habits were fundamentally incommensurable with 'the Swedish way of life' (Montesino, 2002, p. 98). Thus, they argued that zigenare ought to be expelled or otherwise compelled to leave to country:

The assimilation of zigenare seems to us an impossible quest. The only possible solution is to get them out of the country in one way or another. Most of them are likely Swedish subjects, and in any case, it will be difficult to ascertain their citizenship status elsewhere. Therefore, their disappearance from the country cannot be achieved in any other way but by circumscribing their freedom of movement so that they will find it in their own interest to leave to country and emigrate to a country where conditions are more favourable for them.

(Final report of the Committee on the Poor Relief Act, SOU 1923:2, p. 89, cited in DS 2014:8, pp. 167-168, my translation).

This policy never achieved its aim to compel Roma communities living in the country to 'self-deport'. However, it is telling of the exclusionary bordering practices that were operative during the mid-1900s. As has been documented by historians (e.g., Ericsson, 2015; Montesino, 2002; Ohlsson Al Fakir, 2015; Selling, 2013) and officially acknowledged by the Swedish state through the aforementioned White Paper (DS 2014:8), the mid-20th century was a period of severe violations towards people defined as zigenare, including in the form of forced sterilisation (Broberg \& Tydén, 1991). At the time, the zigenare were mostly excluded from regular housing and made to live in camps. They were also pervasively targeted by forced evictions and thus kept continuously on the move, prevented from settling anywhere for more than a couple of weeks at the time (Selling, 2013).

\footnotetext{
${ }^{32}$ The committee also proposed that the children of tattare should be separated from their families and brought up in residential schools, where they would be raised to become virtuous, white citizens. However, this proposal never became a reality (Ericsson, 2015, 2017).
} 
In the post-war period, a Roma civil rights movement was formed that came to challenge these practices. The movement organised around a claim for inclusion into citizenship and for access to schooling and regular housing. In 1952, the previously stateless Swedish Roma were granted citizenship. Two years later, in 1954, the entry ban on zigenare was lifted. This marked a significant turning-point in the state's treatment of the Swedish Roma. Nevertheless, although the group was nominally granted equal rights to education and housing, they continued for a long time to be discriminated against at the local level. It is a well-established fact that the local authorities often refused to register ( $\mathrm{Sw}$ : folkbokföra) the newly emancipated citizens, denying them local residency status and thereby deflecting their claims for a wide range of rights and services to which they were formally entitled (DS 2014:8, pp. 181-192; Montesino \& Ohlsson Al Fakir, 2015; Ohlsson Al Fakir, 2015).

This brief account of the historical development of mobility control and bordering practices has pointed to the shifting rationalities underlying the exclusionary treatment of Roma and Traveller groups. As I will discuss, several of these rationalities echo in the present-day treatment of 'vulnerable EU citizens', including the problematisation of Roma and Travellers as a social burden on the local and national welfare systems and their racialisation through a discourse of moral deviance and inferiority. There is also a continuity between the technologies of selfdeportation proposed by the poor relief committee in the 1920s and present-day control practices targeted at 'vulnerable EU citizens'. 


\section{THE SORGENFRI CAMP}

The Sorgenfri camp was established in the early spring of 2014. For about a year and a half, it served as a makeshift residence for a community of Romanian Roma - most of whom came from Târgu Jiu, a city of about 80,000 inhabitants in south-western Romania. It is difficult to know exactly how many people lived in the settlement as people would come and go, but most counts put the number at about 250 people approximately half of the city's estimated total population of 'vulnerable EU citizens' in 2015. While this makes it a relatively small settlement by European standards, it was numerically the largest, and certainly the most visible, settlement of 'vulnerable EU citizens' in all of Sweden during the years 2014 and 2015. This contributed to making it an object of much contention - a proverbial ground zero in the public and political debate regarding the growth of makeshift and unauthorised tent encampments and settlements ( $\mathrm{Sw}$ : boplatser) in the country.

In this chapter, I first introduce the case of the Sorgenfri camp in more detail. I describe the day-to-day conditions in the settlement and the organising efforts that took place in and around it. I also outline the various attempts by the property owner and public authorities to have the settlement demolished. Finally, I briefly situate the case and discuss its significance in the context of the political debates and policy developments that took place between 2014 and 2016 with respect to 'vulnerable EU citizens'.

\section{An Introduction to the Case}

Gina Ionescu lived in the Sorgenfri camp for a year and a half. Being fluent in English, she quickly emerged as a spokesperson and a tenacious leader within the community. She met and befriended journalist Erika Oldberg, and the two began to collaborate on a biography that would 
relate Gina's life story as well as her experiences in Malmö. The book was published in 2016 with the title Jag är Gina: En berättelse om överlevnad och skam i Europa [I am Gina: A story about survival and shame in Europe]. I draw on it here as a kind of narrative frame to introduce my case study.

Gina came to Malmö in 2014 together with her husband, Valeriu. At the time, she was 25 years old. Originally from Târgu Jiu, the couple had spent the past seven years travelling across Europe in a wearisome search for livelihoods. As members of Romania's impoverished and highly stigmatised Romani minority (Magyari-Vincze et al., 2019), they found it difficult - not to say impossible - to find steady work in Romania. In the summer of 2007 - shortly after the country acceded into the European Union, and about six months after their first son was born - Gina and Valeriu made the difficult decision to leave their infant in the care of Valeriu's parents to go abroad to work on a strawberry farm in Portugal. Later, they decided to try their luck in Italy. When the eurozone crisis hit in 2009, and job opportunities dried up in southern Europe, they ventured up north. By then they had two children, who they brought with them to Helsinki, Finland. The family stayed together in a car on the outskirts of the city, and Gina and Valeriu took turns looking after the boys while the other went into the city centre to beg. In Oldberg's book, Gina describes feeling constantly afraid and anxious that her children would be taken away from her; she had heard rumours that the Finish state could apprehend them, should they find out about their circumstances. After some weeks in the capital, the family therefore decided to return to Târgu Jiu (Oldberg, 2016, pp. 63-69). Over the next couple of years, Gina and Valeriu made repeated trips to Helsinki and Oslo while their children stayed at home with their grandparents.

In 2014, Gina and Valeriu were once again on their way to Oslo when their car broke down half-way through Germany. Some friends of theirs were staying in Malmö at the time. They came to pick them up and drove them to the city. With limited funds to continue onwards, Gina and Valeriu decided to stay in Malmö (Oldberg, 2016, p. 22). Gina was able to take over a spot outside the grocery store Coop at Värnhem, on the 
north-east side of the city, where she would spend her days begging for change (p. 10).

Gina and Valeriu did not have the money to rent an apartment or room for themselves. During their first weeks in Malmö, they squatted in an abandoned building together with their friends. When they were ousted from there, they relocated to a vacant lot where a group of people had already set up a small tent encampment. Gina and Valeriu acquired a cheap two-person dome tent. As Valeriu describes it, the tent could barely withstand the frequent rains and notorious winds from the Öresund belt. The nights were numbingly cold. Everything was wet (p. 11).

The vacant lot where Gina and Valeriu had pitched their tent was a partly weed-covered brownfield site located at the intersection of two thoroughfares - Industrigatan and Nobelvägen - about two kilometres from the city centre in the Sorgenfri area ( $\mathrm{Sw}$ : Sorgenfriområdet). At the time, the lot was owned by Industrigatan i Malmö AB, a subsidiary to the real-estate development firm Granen Fastighetsutveckling $A B .{ }^{33}$ The firm's majority owner - the self-made property magnate Per Arwidsson - acquired the land in 1999 as an investment and left it idle for nearly two decades (Westerberg, 2015). In the cadastre, it is called 'Brännaren 19', but colloquially, it is better known as 'the steppe' (Sw: stäppen) or simply 'the vacant lot' (Sw: ödetomten). As an interstitial space in an otherwise densely built city, 'the vacant lot' had been a hideout for rough sleepers since well before any 'vulnerable EU citizens' arrived in Malmö. Over the years, it had been the site of numerous, often short-lived squatter settlements, as well as guerrilla gardening projects, temporary outdoor art galleries, and a DIY-skateboard park (Andersson, 2010; Knutagård, 2009, pp. 88-90). The property owner had turned a blind eye to such activities, passively accepting the fact that the property had been appropriated and used for a variety of informal activities.

\footnotetext{
${ }^{33}$ In 2017, the company changed its name from Granen Fastighetsutveckling to Arwidsro AB.
} 
In the spring of 2014, when Gina and Valeriu arrived in Malmö, there were only a dozen people living on the site. If you passed by on the street, you would see a collection of tents and a few odd cars and camper trailers arranged in a circle around a patch of gravel, surrounded by stubborn weeds. Over the course of the summer, more and more people settled on the site, and by September 2014, there was an established tent village. As the autumn weather set in and the nights got colder, the squatters began constructing makeshift wooden shacks for themselves to live in - simple box-shaped shacks of pallets and plywood with roofs made of tarps. Some also brought or purchased defunct cars or camper trailers to use for accomodation. Gina and Valeriu scrapped together some money to buy a used trailer off the online marketplace Blocket. It was a major improvement from the leaky tent they had been staying in up to that point (Oldberg, 2016, pp. 39-43). Around this time, the aforementioned local solidarity network, Solidarity with EU Migrants (Sw: Solidaritet med EUmigranter), was formed. They started organising special building days together with the squatters and collected various construction materials, used furniture, woodstoves, and blankets for the squatters to insulate their huts with. Together with the squatters, they also started to pressure the municipality to install portable toilets and provide garbage collection services to the settlement.

It was the activists from Solidarity with EU Migrants who gave the settlement the name I use here - the Sorgenfri camp. The squatters themselves mainly referred to it as 'the platz' ${ }^{34}$ Sorgenfri is the name of the city neighbourhood where the settlement was located. It covers about one square kilometer and consists of a mix of vacant brownfield sites, industrial facilities, residential apartment blocks, and a cemetery (S:t Pauli kyrkogårdar). The neighbourhood derives its poetic name, which literally means 'sorrow free', from a farm that existed here prior to the expansion of the city's industrial base in the early 20th century. Today,

\footnotetext{
${ }^{34}$ In my understanding, 'the platz' is a generic name used by Romanian Roma camp dwellers in many parts of Europe to refer to camp sites. 'The platz' is the name of Swedish photo journalist Joakim Roos's reportages on the living conditions of Roma EU citizens who beg in Sweden (Roos, 2018a, 2018b).
} 
the neighbourhood stands as a remnant of Malmö's industrial heritage. The northern-most part of the area - Norra Sorgenfri - including the lot where the settlement was established, used to house a variety of smallscale industries: a paint wholesaler; various chemical industries; and a vegetable oil refinery that produced soap, sodium carbonate, and glycerine. Norra Sorgenfri was also the site of the city's public gasworks, a waste management facility, and a transit depot. However, with the decline of the city's industrial economy in the late 1980s (Holgersen, 2017), most of these industries closed down or moved elsewhere, leaving behind an industrial ruin of empty buildings and contaminated soil. Surveys conducted by the City of Malmö planning department confirm that the ground here is heavily polluted. Inspectors have found toxic concentrations of chromium and lead, as well as residues of oil and chlorine solutions (Malmö stad Fastighetskontoret, 2007).

In 2006, the municipal planning department presented a plan to turn Norra Sorgenfri into a mixed-use residential neighbourhood. The plan emphasised diversity and the celebration of the 'identity-creating history' of the neighbourhood. It mentioned, specifically, the DIY construction of a skateboard park on the vacant lot as an example of a 'creative enterprise' that lends an urban flair to the neighbourhood and contributes to its 'identity and attractiveness' (Norra Sorgenfri Planprogram, n.d., p. 13). However, in 2014, when the Sorgenfri camp was established, most of the brownfield sites in the neighbourhood had yet to be developed. It is fair to assume that the existence of the settlement was seen as an obstacle for the redevelopment of the neighbourhood, but the development firms were actually remarkably silent on the fate of the Sorgenfri camp. The owner of the specific vacant lot where the settlement was established was mostly passive in regards to the situation. If they acted to exert their influence in order to expediate the demolition, they did so behind closed doors. Instead, it was the municipal authorities that propelled the process forward, putting pressure on the owner to maintain orderly and sanitary conditions on the lot. 


\section{A Space of Destitution, a Space of Defiance}

Notably, the Sorgenfri camp was not the only so-called unauthorised settlement of 'vulnerable EU citizens' in Malmö in the years 2014-2015. There were at least two other well-known settlements in the city. One was located in a forested area in the public park, Pildammsparken. The other was hidden away by the train tracks at Singelgatan, in the city's outskirts. Moreover, there were many smaller, short-lived encampments, including one at Dalaplan that burnt down in November 2014, possibly as a result of arson ('Brand i läger misstänks vara anlagd,' 2014).

Within camp studies literature, a distinction is sometimes made between state-enforced internment camps and 'counter camps' that are constructed on an informal basis by people on the move, either out of pure necessity or as a form of social and political protest (Minca, 2015a, pp.90-91). The Sorgenfri camp fits the description of a counter camp. It can be argued, as Hansson and Mitchell (2018) so incisively do, that it was the product of an deliberate if implicit state policy of 'control through abandonment' (p. 26, emphasis in original) - and in that sense indirectly state-enforced. But unlike the institutionalised Roma and Traveller campsites that exist in many other European countries, the Sorgenfri camp was not sanctioned by any authority. Quite the opposite, the authorities worked hard to have it removed.

Although it was not set up with an explicit political agenda in mind, the Sorgenfri camp was still from the very beginning an intensely contentious space. It made apparent the dire conditions of many 'vulnerable EU citizens', projecting an image of imminent crisis into the public consciousness, which in turn put pressure on the authorities to do something to address the situation. Taking the Sorgenfri camp as a key example, the 2016 report of the National Coordinator (i.e., the aforementioned Valfridsson report) suggests that the existence and growth of unauthorised settlements of 'vulnerable EU citizens' has tended to trigger a 'dynamic of extremes' (Sw: en ytterligheternas dynamik). On one end of the spectrum, there are openly xeno-racist factions who target these settlements with vandalism and sometimes direct bodily violence. 
On the other, there are autonomous activists who practice civil disobedience in the name of socially progressive values - sometimes by attempting to physically block an eviction, sometimes by aiding in the reestablishment of so-called illegal settlements (SOU 2016:6, 47-48).

It has been pointed out that the visibility of camp-like spaces can be a double-edged sword. On the one hand, it may bring attention to the situation and demonstrate the political subjectivity of groups outside the remit of citizenship and other rights. On the other hand, there is a danger in visibility as it may invite violence and increased policing (cf. Clough Marinaro, 2014a; Darling, 2016, p. 14; Maestri, 2019; Sigona, 2014). The visibility of the Sorgenfri camp certainly made it an object of strong antipathies and a target of direct violence. The squatters were subjected to instances of harassment and assault, including an alleged case of attempted arson (Oldberg, 2016, pp. 32-33; Palmkvist, 2015)..$^{35}$ For the most part, those who were dismayed by its existence took to social and alternative media to express their disaffections. As I will discuss in more detail further on, many also contacted the municipality to complain about the squatters and about the alleged impotence of the authorities to have the settlement removed. When I google 'the Sorgenfri camp' (Sw: Sorgenfri-lägret), one of the top hits is always an anonymous blog called Politik \& Partier [Politics and Parties], with a banner that lists 'Islamists', 'terrorists', 'Muslims', 'climate activists', 'UN personnel', 'EU politicians', 'foreign citizens', and 'those of foreign origin' as 'the societal groups that constitute the biggest threat to Sweden' (sic). ${ }^{36}$

\footnotetext{
${ }^{35}$ The specific incident (i.e., the arson attack) took place late at night on November 20, 2014. One of the squatters, a 54-year-old man who had pitched his tent at the edge of the settlement near the fence to Nobelvägen, woke up to discover that his mattress was in flames. He managed to get out in time before getting seriously injured, but he suffered a burn to his foot. Meanwhile, some of his neighbours put out the fire before it spread to the surrounding tents and shacks. The incident was followed closely by another known case of arson that affected another smaller tent encampment of Romanian Roma on the opposite end of the city, at Dalaplan. The police investigation did not yield much evidence, but the police speculated that it could have been other 'vulnerable EU citizens' who attacked the encampments, possibly as a tactic of intimidation in a struggle over turf (Palmkvist, 2015).

${ }^{36}$ The owner of the blog has apparently spent a significant amount of time in and around the Sorgenfri camp.
The site contains many entries about the settlement, with close-up photographs and detailed descriptions of
the place and its residents. The entire list of entries on the Sorgenfri camp is available via the following link:
} 
That said, I am convinced that the very visibility of the Sorgenfri camp contributed to keeping the public debate about the responsibility of the Swedish state to variously offer assistance to 'vulnerable EU citizens' alive. It also made it impossible to hide from view the more coercive or legally dubious aspects of the authorities' attempts to have squatters removed, thus stoking a discussion about the repressive aspects of state policy and practices towards 'vulnerable EU citizens'. Since the demolition of the Sorgenfri camp and the subsequent implementation of the National Coordinator's zero-tolerance approach towards unauthorised settlements, there has definitely been less public debate about these issues.

Furthermore, if the Sorgenfri camp was a prominent object of contention, it also constituted an important space for self-organising and for activist and community work on the part of outside groups. This seems to confirm an argument made by Gaja Maestri (2017) and other ethnographers within the field of camp studies, namely that camps can function as spaces where collective political subjectivities are shaped from below (see also Alkhalili, 2017a, 2017b; Clough Marinaro, 2019; Rygiel, 2011, 2012; Sigona, 2014). ${ }^{37}$ I certainly do not want to glorify life in the Sorgenfri camp - the hardships were real, and the squatters' had their share of interpersonal disputes. Relationships among the squatters (and between squatters and outside activists) were also hierarchical, marked by differences in status and power. Nevertheless, the settlement provided its inhabitants with a relative measure of stability and safety and allowed for

http:/hotpot.se/politik/index/\#EU-migranter. I know from analysing the complaints to the City of Malmö regarding the Sorgenfri camp that the same person who manages the site has written numerous e-mails to the city administration with detailed commentaries about the case.

\footnotetext{
${ }^{37}$ The argument has been developed in response to the Italian philosopher Giorgio Agamben's $(1998,2005)$ influential account of 'the camp' as a space of exception, a 'zone of indistinction' where non-citizens are kept indefinitely in a situation of simultaneous exclusion and inclusion, and which effectively strips its inhabitants of their political subjectivity, thus reducing them to 'bare life'. A similar argument - that camps are spaces of collective organising and subject formation - is sometimes made with regards to 'the ghetto' (Clough Marinaro, 2015, 2017; Ryan Powell, 2013). Loï Wacquant's influential theory of the ghetto identifies the development of internal community organisations, solidarity, and activism as one of the core structural features of the ghetto (see Wacquant, 2011).
} 
a degree of self-organising. Not having to constantly carry their belongings with them or worry about where they were going to spend the next few nights made a difference in the squatters' day-to-day lives. It freed up time to do other things: to spend more time panhandling or collecting bottles, sure, but also to take time to plan ahead, practice language-skills, and apply for work; to make a long since overdue visit to the dentist or to a health care centre; to cook and prepare healthy meals; to salvage materials to reinforce the makeshift huts so that they would better withstand the elements; or to build friendships with others in the settlement. The fact that the squatters were living together on the same site also allowed them to share the burden of constantly having to watch over the space, their belongings, and personal safety. There was a sense of safety in numbers. For instance, in the wake of the alleged arson attack, a rotating schedule was implemented where residents along with nonresident activists from the solidarity network would take turns guarding the premises.

Over the course of the settlement's one-and-a-half year lifespan, a number of different activist organisation involved themselves in efforts to support the squatters and advocate for their cause. In addition to Kontrapunkt and the aforementioned volunteer network, Solidarity with EU Migrants, there was also the street-law collective Centre for Social Rights and the Malmö-chapter of the self-proclaimed revolutionary leftist organisation Allt åt alla (Everything for Everyone).

The volunteers of Soldarity with EU Migrants were the first ones to approach the squatters. During the autumn of 2014, they collected scrap construction materials and helped organise building days in the settlement; they assisted individual residents in accessing welfare services and health care (e.g., by accompanying them to appointments with social workers and health care professionals); and they participated in negotiations and public debates with the city administration and council. As one of my interviewees describes it, the work was incessant, never-ending, exhausting. They were 'constantly putting out fires' (interview with solidarity activist 1, Oct 6, 2015. 


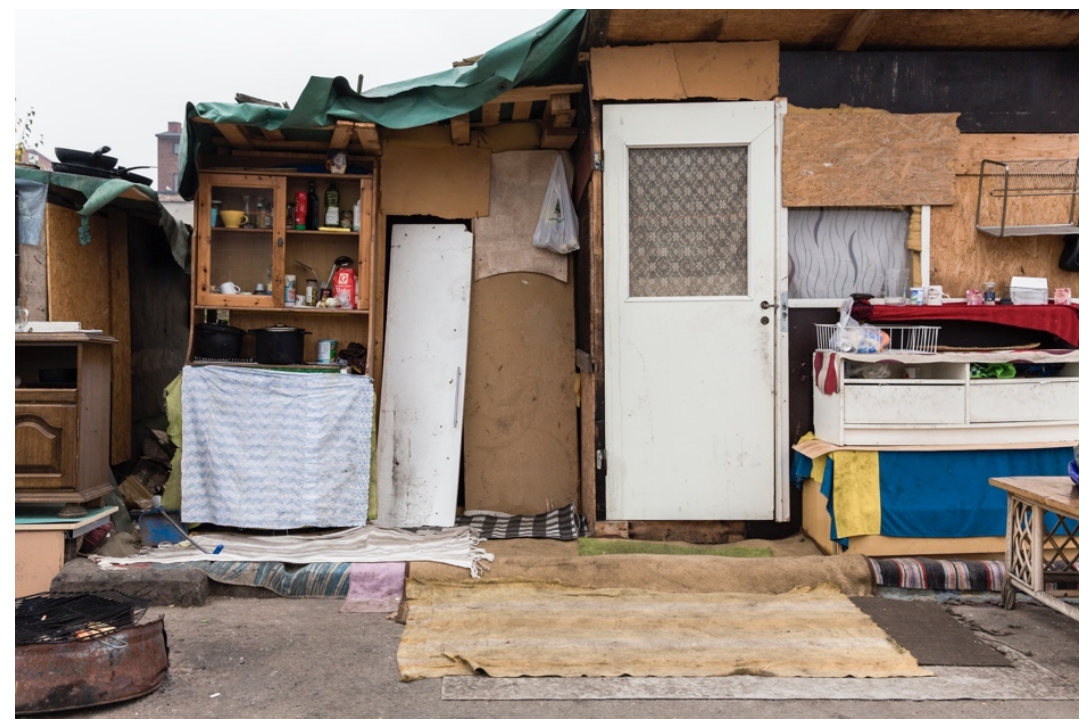

Figure 4. Spaces of domesticity, the Sorgenfri camp

(C) Jenny Eliasson / Malmo Museums

Around the turn of the year (2014-15), Kontrapunkt stepped in to back up their efforts. As an established social centre, they were in some ways better equipped to shoulder the ongoing community-support work. Over time, they also came to strongly influence the direction and strategy of activists organising in and around the settlement. The organisation thought it important that the squatters should organise collectively to selfmanage the settlement and step forward as activists in their own right. They encouraged them to articulate their claims and to organise demonstrations. In a somewhat similar vein, the leftist activist organisation Allt Åt Alla sought to find common ground and create an alliance with the squatters. The organisation as a whole focuses mainly on urban politics and issues of gentrification and, as they saw it, getting involved with the squatters' struggle was consistent with their overall aim of organising neighbourhoods against capitalist urban development and advancing the right to the city (cf. C. Hansen, 2019, pp. 344-354). The street-law collective Centre for Social Rights (CSR), participated in the organising efforts by advocating on behalf of the squatters; they appealed 
the various eviction orders and represented the squatters in meetings and negotiations with the city administration.

As Christina Hansen (2019) observes in study on place-based solidarity activism in Malmö, the relationships between the squatter-activists and the solidarity groups were not always easy. The alliances between the squatters and the various activist groups were forged across deep-running differences and inequalities. They were imperfect, marked by recurrent disagreements and tensions. For example, there were conflicts and continuous negotiations between the squatters' immediate interests and the sometimes quite lofty visions of the solidarity activists. Many of the squatters were also sceptical of the activists' initial suggestions that they should engage in direct action and public demonstrations; some felt anxious about the possible repercussions, while others were doubtful that it would make any difference (C. Hansen, 2019, p. 359). Nevertheless, when push came to shove, the squatters came out in significant numbers to defy the attempts to evict them and to protest the lack of positive interventions on the part of the City of Malmö.

The squatters' main and primary demand was for an alternative, officially-sanctioned campsite that they could relocate to. In connection with each one of the City's attempts to close down and demolish the settlement, they staged protests, affirming their refusal to go without an adequate and appropriate resettlement option. For example, on March 25, 2015, when the City Council met to vote on a proposal for a policy action plan for 'vulnerable EU citizens', the squatters together with Allt Åt Alla filled the gallery of the council meeting room, holding banners that read 'The Right to Housing should be Unconditional' (Sw: Rätten till bostad ska vara villkorslös) (Fjellman, 2015).

In the months preceding the demolition, with the imminent threat of eviction looming large over their heads, the squatters and their allies reinvented their collaboration. An umbrella network was formed with the name The Network for Roma Rights (Sw: Nätverket för Romers Rättigheter), replacing the previous volunteer network Solidarity with EU Migrants. As I understand it, the name change was intended to foreground 
the leadership of the squatters themselves; it signalled that it was an organisation made up of Roma-identified persons rather than a volunteer network set up to offer support for passively suffering EU migrants. Crucially, the name change also served the strategic purpose of reframing and re-scaling the struggle over the Sorgenfri camp, elevating it from a local struggle over a single tent encampment into a question of internationally enshrined Roma rights. This proved to be a smart move. In particular, it allowed the squatters and their allies to reach out and ask for support from other Roma and Traveller community organisations, as well as from national and international minority rights advocacy groups. As one of the initiators of the network stated in an interview I did with them in march 2017,

We created the Network for Roma Rights to shift the emphasis from the issue of EU migrants to the Roma question. My sense is that people appreciated being able to assert their Roma identity and feel strong in it, at least at the time. It also made a difference for them that we, as non-Roma, recognised this and affirmed their identity. And, it shifted the focus of the struggle, not least because it brought the attention of the UN and the Council of Europe. It made it into a question of minority Roma and Roma rights rather then it being - and I would like to put this in scare quotes - simply a question of poor people's rights. (interview with solidarity activist 2, March 17, 2017)

\section{'A Major Nuisance in Our Backyard'38}

The sanitary conditions in the Sorgenfri camp were always deplorable. There was no running water and no sanitary facilities. The nearest public toilet was a ten-minute walk away. Trash piled up along the perimeters of the site. The ground was heavily contaminated.

Having received multiple private nuisance complaints regarding the settlement, the municipal Environmental Administration (EnA) initiated an inspection (Sw: tillsynsärende) in the late spring of 2014. As a first step, they contacted the property owner and ordered them to remove the

\footnotetext{
${ }^{38}$ The sub-heading is a quote from one of the many nuisance complaints that were addressed to the City of Malmö regarding the Sorgenfri camp. I discuss these in chapter five.
} 
litter from the site. When the company failed to do so, the authorities moved to prohibit the squatters from staying on the site on the basis of environmental law. This was the start of the convoluted process that eventually led to the demolition of the settlement on November 3, 2015. I account for the intricacies of this process in chapter six. Here, it suffices to note that the both the property owner (Granen Fastighetsutveckling $\mathrm{AB}$ ) and the Environmental Administration attempted multiple times to have the squatters evicted from the site. Each time, they encountered a kind of practical-legal Catch-22. As a basic due process requirement, all formal eviction orders need to be addressed to a named individual to be valid. In most eviction cases, this is just a formality, but in the case of the Sorgenfri camp, the steady turnover of people on the site (combined with other factors) made it difficult - not to say impossible - for the property owner to obtain the names of the squatters. For this reason, they could not have them removed through a regular eviction procedure. The administration, on their part, encountered a very similar problem when they attempted to issue a prohibition order to forbid people from staying on the site. Meanwhile, the squatters, with the support of the street law collective Centre for Social Rights, were also able to strategically use this requirement to obstruct the process and defer their displacement.

Through some rather complicated legal acrobatics, the Environmental Administration ultimately found a way to get around the relevant due process requirement by mobilising a specific environmental law mechanism that allowed them to treat the settlement as an urgent nuisance issue. In technical legal terms, the ultimate decision to demolish the settlement was justified as a means to do away with the settlement, not because it constituted an unauthorised occupation, but because it had been declared by the Environmental Administration of the City of Malmö as a nuisance to neighbouring communities as well as a major risk to the health and safety of the squatters themselves (Malmö stad Miljöförvaltningen, 2015).

Crucially, the residents of the Sorgenfri camp, along with the solidarity groups, made repeated request to the municipality to have sanitary facilities and a garbage container installed on the site. However, as I will 
discuss in more detail in the following chapter, the municipality rejected their requests. Instead, the various solidarity groups fundraised to rent a set of porta-potties and a garbage container for the site. The squatters also organised regular cleaning days in the settlement in an attempt to avert the threat of removal (interview with solidarity activist 2, March 17, 2017). In the end, this did not make much of a difference.

\section{'Don't Throw Us Out Like Trash'}

On October 2, 2015, a newspaper report in Sydsvenskan revealed that the evacuation and demolition of the Sorgenfri camp would soon be underway. The police was gearing up for an 'enormous operation' having allegedly assigned a minimum of 160 police officers from across southern Sweden to participate in the evacuation, while ordering another 600 officers to be on standby (Palmkvist, 2015). At this point in time, there were about 200 individuals staying in the settlement.

Shortly thereafter, it was announced that the City of Malmö's Environmental Council (Sw: Miljönämnden) would vote on a proposal to evacuate and demolish the settlement. The vote took place on October 27 , 2015 and was nearly unanimous: All council members except for the left party representative voted in favour of the proposal. The squatters were notified that they would have five days, until November 1,2015, to collect their belongings and evacuate the property. The Social Services Administration announced that they would set up an emergency shelter for up to 50 people for five nights. Those who opted to return to their hometowns in Romania would be offered bus tickets.

In the afternoon on November 1, 2015, hundreds of people gathered at the site of the settlement. The squatters had moved most of their belongings off the grounds already. Some had left town, or were planning to do so in the coming days. Others had resolved to stay until the wrecking crews arrived. Frayed banners hung from the chain-link fence that surrounded the settlement. One of them read in bold black letters 'Don't throw us out like trash!'; another one read 'Excuse us for disturbing you!'. 
An accordion player helped keep the crowd on their feet, alternating between Kaoma's 1989 hit 'Lambada' and Romanian protest singer Stelian Maria's 'Nu plecăm acasă' (We will not go home!). On one side of the street, residents from the settlement were gathered together with activists from the solidarity network and others who had come out to express their support. On the opposite side of the street, a separate group of people, obviously hostile to the squatters, had gathered to witness the demolition of the settlement. It was a very visual and very visceral manifestation of just how divided public opinion was.

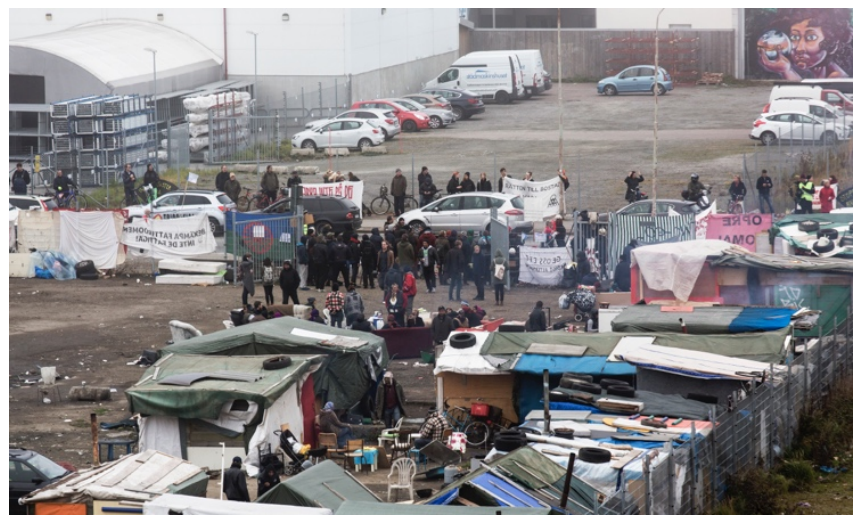

Figure 5. The Sorgenfri camp, the day before the demolition, November 2, 2015. Residents, solidarity activists, journalist, and antagonistic protestors are swarming about the place. (C) Jenny Eliasson / Malmo Museums

No wrecking crews showed up that Sunday. Instead, they waited until the wee hours of the morning on November 3, 2015, to 'evacuate' the settlement. The following is an excerpt from my field notes from that day:

I received a text from a friend that the police would likely arrive soon, and I biked over to the camp shortly after midnight. I arrived to find a motley crew of solidarity activists, sleepless wanderers, a lone legal observer, a film team from Al-Jazeera, and numerous other journalists. All were there to bear witness to what was about to go down. Not much was left of the camp at this point. Some were rushing to fix a flat tyre on a camper - the last one remaining in the settlement, which had otherwise been reduced to collection of barely standing sheds surrounded by heaps of garbage and discarded furniture. In the centre of the lot, there was a bonfire, with damp couches and arm 
chairs arranged in a circle around it. I watched as three men hurled one piece of furniture after another onto the fire: bedframes, fibreboards, pallets, and a wicker lounge chair. I recognised some of the items and knew that they had been salvaged from around the city, repaired, and arranged in an intimate practice of home-making, of domesticity. On the brink of the evacuation, however, their only value was as firewood. The lounge chair was quickly engulfed by the flames and disintegrated into a swarm of crackling embers.

The police arrived at about five o'clock in the morning. The place was now swarming with journalists. The squatters and their allies clustered around the gate, the only opening in the fence, and locked arms to prevent the police from entering. However, it did not take long for the police to break up the crowd. First, they carried those who they recognised as sympathisers and solidarity activists off the site. The squatters and a few of the solidarity activists were allowed to remain in a cordoned off area of the settlement for another hour or so before they, too, were ushered off the site. The police searched through the few remaining sheds. Soon thereafter, city workers pulled in with excavators and garbage trucks.

The City of Malmö did not accede to the squatters' demands for an alternative site, and once the settlement had been razed to the ground, the evacuees found themselves on the street with minimal access to shelter. The city's regular homeless shelters would not make room for them, and the designated winter shelter for 'vulnerable EU citizens' would not open for another month.

The squatters and their allies set up a sleep-in protest outside City Hall. Their demand was for a roof over their heads and a warm and safe place to sleep. Volunteers brought food and beverages, blankets, matrasses, and dry socks. All the while, there was a massive police presence on the scene, surrounding the protestors and guarding the entrance to the town hall. Once it became clear to the police that the protesters were not going to leave the site, they began to confiscate their blankets and matrasses. After ten days of rain and hard winds - having had their banners, blankets, mattrasses, and tarps repeatedly confiscated and discarded - the squatters eventually decided to discontinue their protest. Some found refuge in a nearby church, which had originally opened its doors to newly arrived refugees during the 'long summer of migration'. Others were able to stay 
for a few months at Kontrapunkt's volunteer-run shelter. A year after the demolition, the newspaper Sydsvenskan reported that there had been a significant increase in the number of complaints regarding unauthorised settlements around the city since the demolition of the Sorgenfri camp (Funke, 2016).

As I will discuss in detail in the following chapters, the efforts on the part of the local authorities in Malmö to have the Sorgenfri camp demolished both paralleled and intersected with the national-level legislative and policy development process. The timeline on the following page situates the conflict over the Sorgenfri camp in the context of the national policy development process and provides an overview of significant events discussed in the remainder of the thesis.

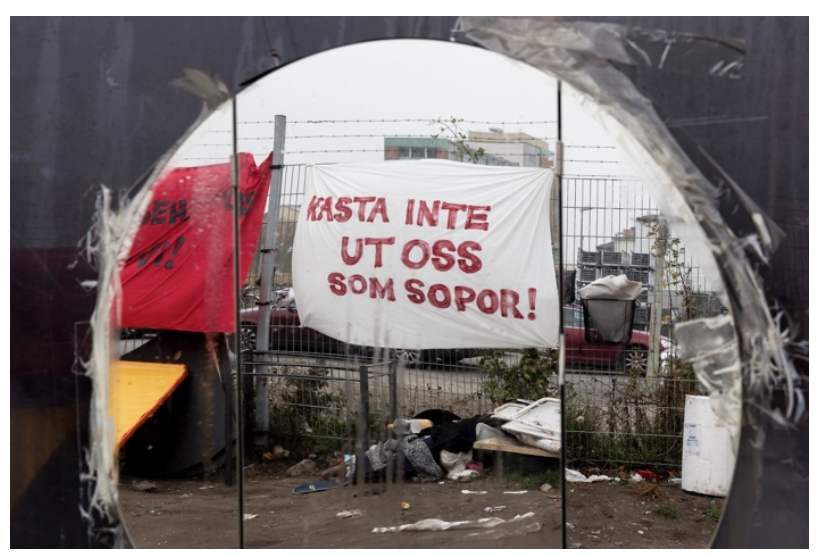

Figure 6. 'Do not throw us out like trash!' (C) Jenny Eliasson / Malmo Museums 

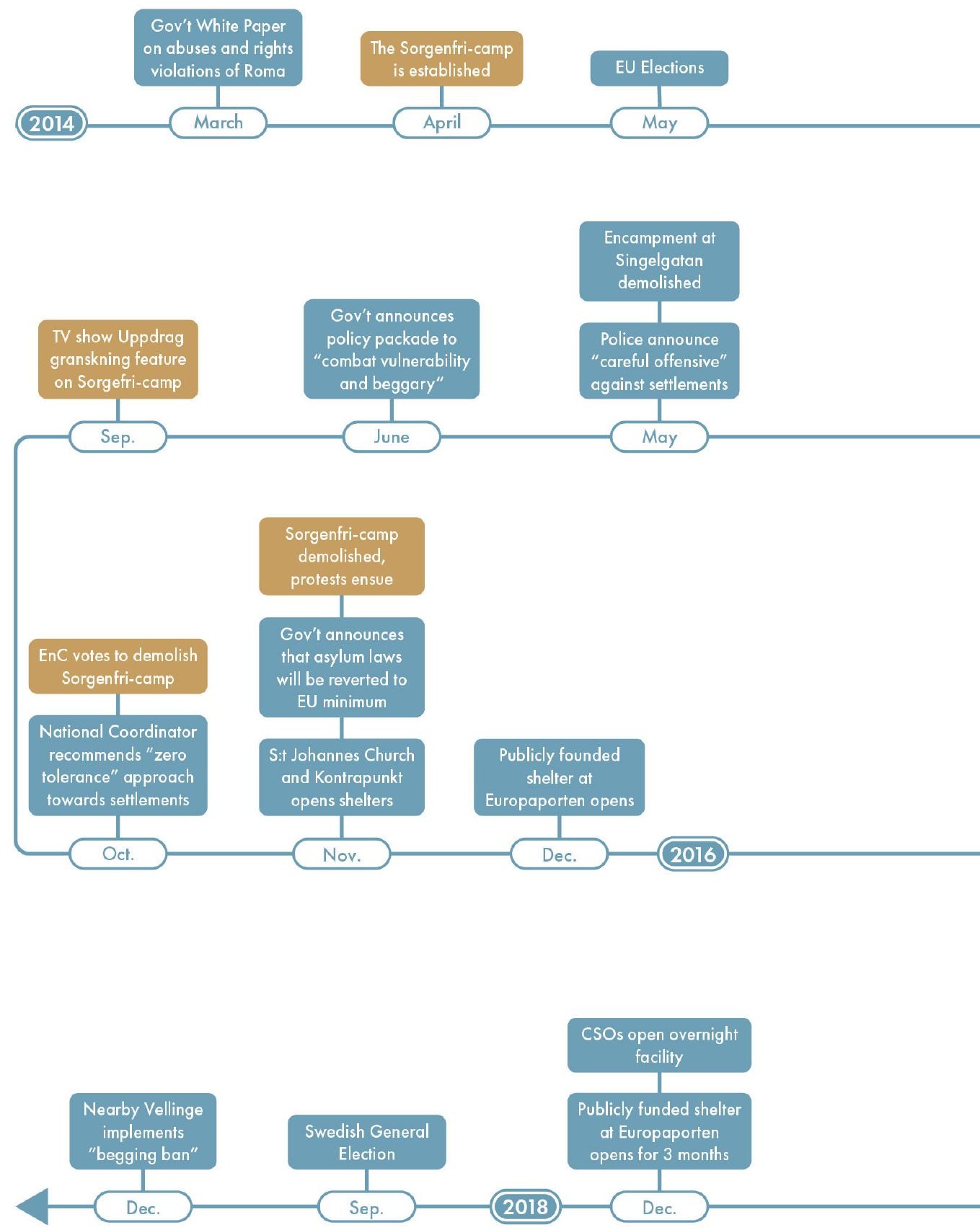
V. Zamfir dies following

alleged arson attack

against tent camp in Sthlm

Swedish General Elections

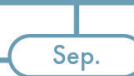

Arson attack against the

Sorgenfri-camp

Meetings between City and

Solidarity w/EU-migrants
Appointment of a

National Coordinator for

Vulnerable EU-citizens

Crossroads service centre opens in Malmö

$$
\text { Nov. }
$$

Jan.

\section{Encampment in}

Pildammsparken demolished

Sorgenfri-camp

again threatened

with demolition

City Council approves

Action Plan amidst protests

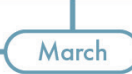

Sorgenfri-camp

threatened with

demolition

April

March

Feb.

Report of the National

Coordinator for

"Vulnerable

EU-citizens"

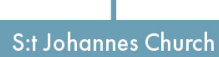

and Kontrapunkt

shelters forced to close,

protests ensue

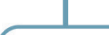

Review of

Enforcement Code

proposes to "improve

possibilities" for

removing settlements
Legal mechanism of

removal added to

Enforcement Code
Frequent reports that

people are being fined

for sleeping in cars

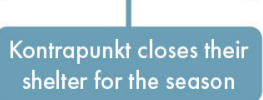

shelier for the season
Kontrapunkt opens

new overnight

facility for 3 months

Publicly funded shelter at

Europaporten

opens for 3 months

\section{July}




\section{EVICTED, BECAUSE EVERYONE SHOULD HAVE ACCESS TO GOOD HOUSING}

In the previous chapter, I introduced the Sorgenfri camp case and outlined the intensely contested process that ultimately led to demolition of the settlement. In this chapter, I want to hone in on the cultural politics that shaped this process and interrogate the material-discursive production of the settlement as an environmental nuisance ( $\mathrm{Sw}$ : olägenhet) and sanitation hazard..$^{39}$

The Sorgenfri camp lasted for a year and a half, during which the City of Malmö received over 200 private nuisance complaints regarding the settlement. On November 5, 2015, just two days after the demolition, the following e-mail showed up in the main inbox of the Environmental Administration. This was just one of many reactions to the event. The administration and the responsible politicians received numerous emails and phone calls expressing appreciation for their decision to evacuate and demolish the settlement (Magnusson, 2015). However, this particular complainant wanted to voice their resentment over what they claimed was a 'long overdue' response on the part of the authorities:

Hell no, Sweden has no responsibility to fix a life for them, they should be grateful that they were not shot or injured. Now, the coddling needs to stop. There are rules here that we Swedes follow. And they, goddamn parasites on Swedish society, ought to just fucking [Sw: ta mig fan] do as they are told. That is, they need to move

\footnotetext{
${ }^{39}$ Here, I use the term 'cultural politics' to refer to the way that culture - including popular attitudes, beliefs, opinions, and perspectives - comes to have tangible political effects by forging communities, reproducing differences and inequalities, and vindicating exclusions (Mitchell, 2000; D. S. Moore, Pandian, \& Kosek, 2003, p. 2).
} 
away from here. They are not wanted anymore. They only create problems for us honest Swedes. Dirty mattresses, rubbish, pissing, shitting around where they, so to speak, live. Is this really what we common Swedes want from foreigners? ... If foreigners are going to enter into Sweden, the authorities must demand that they behave, make a normal life, find appropriate accommodation, big or small with a shithouse where they might relieve themselves. Damn, things cannot continue in the same despicable and disrespectful way as they did in the Sorgenfri area. (complaint to the City of Malmö, November $5,2015){ }^{40}$

Undoubtedly, this was an especially crude message. The majority of those who contacted the administration about the Sorgenfri camp did not speak of the squatters as 'parasites'. Neither did they suggest that they 'should be grateful that they were not shot'. I begin the chapter with this excerpt, not because it is so shockingly aggressive, but because it illustrates how descriptions of the settlement and its inhabitants as an environmental and sanitary nuisance would often slide between discursive registers, linking intimate aversions around hygiene to wider anxieties over the integrity and security of Swedish society. As such, it is exemplary of what I will call 'nuisance talk' - an affectively charged lay discourse that sees the settlements of 'vulnerable EU citizens' as defiling and 'out of place'.

I borrow the term 'nuisance talk' from Asher Ghertner's (2012, 2015) work on the cultural politics of slum removal in millennial Delhi, India. Ghertner uses it to describe the narratives through which members of the city's property-owning middle class would depict slums as threats to their visions of Delhi as 'world-class city', and to show how such 'talk' moved from everyday conversations among neighbours into official discourse

\footnotetext{
${ }^{40}$ As the complaints are not so easily accessible as some of my other materials I have opted to include the untranslated original text in the footnotes. Original: 'Fan heller, Sverige har inte skyldighet att fixa ett liv för dem, de skall vara tacksamma att de inte blev skjutna eller skadade. Nu måste fjäskandet vara slut. Här finns regler, de följer vi svenska och de förbannade parasiterna i svenska samhället skall-bör ta mig fan göra det som de blir tillsagda att göra, dvs flytta härifrån, de är inte önskvärda längre. De skapar bara problem för oss hederliga svenskar. Skitiga madrasser, bråte, pissande, skitande runt där de sk bor. Är det verkligen de vi vanliga svenska vill ha av främmande människor? [...] Om främmande människor skall komma in i Sverige, bör myndigheterna ställa krav att de är här för att sköta sig, skapa ett normalt liv, sedvanlig bostad, stor eller liten med skithus där man gör sina behov och fan inte på detta avskyvärda, respektlösa sätt som nu skett i Sorgenfriområdet.'
} 
and state policy. Extending Mary Douglas's (2002) influential argument about the symbolic meaning of dirt, I will similarly show how representations of the Sorgenfri camp as unsightly, dirty, and disorderly positioned the squatters living there as being out of place and simultaneously provided a legal rationale for their removal.

The analysis will proceed in three steps. First, I will consider the nuisance complaints that were addressed to the City of Malmö regarding the Sorgenfri camp, many of which attributed the conditions in the settlement to the behaviour of the squatters themselves as proof of their essential Otherness and inferior moral character. I doing so, I will discuss the relationship between the depiction of the unauthorised settlements of 'vulnerable EU citizens' as threat to ostensibly 'Swedish' norms of lawfulness, order, and sanitation and the problematisation of 'vulnerable EU citizens' as unwanted or even illegitimate immigrants to the country as such. Second, I will consider how municipal politicians and public officials at the City of Malmö related to such representation of the settlement and how they justified their decision to demolish the settlement, in positive terms, as a form of nuisance abatement - a means to care for the well-being of the squatters and ensure that standards of cleanliness, health, and safety were maintained for the benefit of the public at large. However, I begin with a brief theoretical discussion of 'nuisance talk' and the symbolic meaning of dirt.

\section{The Symbolic Meaning of Dirt}

Mary Douglas first published her treatise Purity and Danger in 1966. Since then, scholars across the humanities and social sciences have drawn on it to show how notions of dirt, pollution, and waste are used to represent both residual people and places (see Appadurai, 1998; Campkin, 2013; Cresswell, 1997; Hayden, 1996; Malkki, 1995; Sibley, 1995; Stallybrass \& White, 1986). For me, it provides a starting point for thinking about how seemingly technical and objective categories of urban environmental law and public space regulations (nuisance being a key example) are always contingent on historically and geographically specific norms of order and propriety and for considering the relationship 
between the routinised practices of nuisance governance and sociopolitical processes of exclusion/inclusion.

According to Douglas (1966/2002), dirtiness is not an intrinsic quality of certain objects. Nothing is dirty in and of itself. Rather, dirt is a 'relative idea'. Douglas illustrates this point with the mundane example of shoes. She argues, shoes are not dirty as such; however, when placed on a dining table or worn to bed, they become dirty (p. 44). Similarly, bodily materials like hair and fingernail clippings are transformed into bodily wastes (and thus redefined as dirty) precisely at the moment when they are physically removed from the body. Douglas' conception of dirt is thus a spatial one: dirt is defined not by what stuff is but where it is. In her words, dirt is 'matter out of place'. From this follows that any notion of dirt relies on an underlying, often unsaid and unquestioned, symbolic order - a 'structure of proper places' (Cresswell, 1997, p. 334). Indeed, Douglas (1966/2002) emphasises that dirt exists only and always in relation to the symbolic order that it is seen to violate: dirt is 'the by-product of a systematic ordering and classification of matter, in so far as ordering involves rejecting inappropriate elements' (p. 44). Douglas (1966/2002) especially draws attention to ambiguous phenomena - those that do not fit into already existing classificatory schemes and therefore disrupt these schemes. These phenomena are not just in the wrong place. Rather, they appear to be altogether 'placeless', 'left out of the patterning of society' (p. 118). Having no proper place, such phenomena are often seen as defiling of purity and disruptive of order, and as such, they tend to excite both fear and loathing. ${ }^{41}$

A similar line of thinking appears in Julia Kristeva's work on the psychic process of abjection, which Sibley (1995) defines as 'that unattainable

\footnotetext{
${ }^{41}$ As Davina Cooper notes, it is no coincident that Roma and Travellers, who are often misrepresented as being quintessentially 'placeless' (belonging nowhere), are so often associated with notions of dirt, impurity, and nuisance (Cooper, 2002, p. 24).
} 
desire to expel those things which threaten the boundary' (p. 18). ${ }^{42}$ Kristeva (1982) herself remarks,

Abject. It is something rejected from which one does not part, from which one does not protect oneself as from an object. ... It is thus not lack of cleanliness or health that causes abjection but what disturbs identity, system, order. What does not respect borders, positions, rules. The in-between, the ambiguous, the composite. (p. 4)

Excrement is the quintessential example of an abject substance as it stands for the breakdown of the distinction between the Self and the Other. ${ }^{43}$ In Kristeva's (1982) words,

Excrement and its equivalents (decay, infection, disease, corpse etc.) stand for the danger to identity that comes from without: the ego threatened by the non-ego, society threatened by its outside, life by death. (p. 71)

While Kristeva is concerned with the psychic process of abjection, others have elaborated on her work to consider abjection as a socio-political process and experience (e.g., Butler, 1993; Tyler, 2009). This is also how I prefer to use the concept. Abjection as a socio-political process is an 'act of force', one that 'acts upon persons and collectivities such that some ways of being, some forms of existence ... are rendered beyond the limits of the liveable, denied the warrant of tolerability and accorded purely a

\footnotetext{
${ }^{42}$ For Kristeva (1982), abjection is a psychic and, at the same time, visceral process: it involves disgust and horror as well as desire and fetishism, and it occurs through intimate and often violent acts of rejection (p. 13). Whereas Douglas frequently downplays the theme of violence, Kristeva's theory of abjection suggests that the maintenance of purity and order rests on the violent expulsion of all that is deemed defiling and disorderly. My analysis focuses on the cultural politics of abjection rather than on its psychic dimensions. Like Kate Hepworth (2012), I prefer to downplay the 'psychoanalytic resonances' of the concept. But I also agree with Hepworth (2012) that 'it is only through the viscerality of Kristeva's writing ... that the intimate and excessive reaction to the abject is conveyed' (p. 432). It is difficult to account for the intensity of emotion - the expressions of utter disgust, and even hatred - that comes through in the complaints to the Environmental Administration without some recourse to psychoanalytic theories. What is primarily of interest to me though is how such descriptions circulate in public discourse, and how they contribute to shaping municipal policy and practice.

${ }^{43}$ If the abject is constitutive of the subject, this means that the subject cannot ever rid itself completely of the abject. (For Kristeva, this is in essence what distinguishes the abject form the low-object, the Other). Neither 'subject nor object', the abject 'lies there, quite close, but it cannot be assimilated' - nor can it ever be completely eliminated (Kristeva 1982, p. 1).
} 
negative value' (Rose, 1999, p. 253). Importantly, abjection - much like the acts which Douglas calls 'patterning' - is to be understood as a constitutive force: Abjection is the process whereby the subject 'constitute[s] itself through the expulsion of that which it is not' (Hepworth, 2012, p. 433; see also Butler, 1993). At the level of the social, abjection works to construct the identity and demarcate the boundaries of social groups and the places with which they are associated. 'Abjection thus generates the borders of the individual and the social body' (Tyler, 2009 , p. 79 , my emphasis). Scholarship on racially or ethnically predicated segregation have noted the significance of the pure/impure binary in constituting abject racialised spaces (e.g., Sibley, 1995), including in the form of Roma camps (Clough Marinaro, 2009, 2014b; Ivasiuc, 2015a; Picker, 2017).

One of my arguments in this chapter is that the abjection of 'vulnerable EU citizens' as 'non-Swedish', 'foreign', or 'Roma' serves to rearticulate cleanliness and order as distinctly Swedish virtues and reinforce a vision of Sweden as a clean country. Notably, this is a vision with deep and rather troublesome historical roots. Nationally inflected discourses of cleanliness - more specifically, of social hygiene - played a significant role in the establishment of the Swedish welfare state, the People's Home (Sw: Folkhemmet) (Broberg \& Tydén, 1991; Hirdman, 1989; Molina, 1997). The history of modern Sweden is often told in triumphant terms as the story of the eradication of abject poverty and filth. However, this history cannot be separated from the history of the eugenics and racial hygiene programs of the mid-20th century or from the longer history of state-racism towards Roma and Traveller groups, the Sámi people, and racialised immigrant communities (Amin et al., 2002). Just as notions of cleanliness were key to the social imaginary of the emergent socialdemocratic welfare state, they played an instrumental role in the forced sterilisation programs of the mid-20th century (Broberg \& Tydén, 1991; Lucassen, 2010). More broadly, discourses of dirt and uncleanliness have also long played a role in the construction of Roma and Traveller groups as abject outsiders to Swedish society (Ericsson, 2015; Montesino, 2002; Tervonen, 2010). 
Here, it might be noted that the slum (and the associated notion of the shantytown) occupies a special symbolic status in the history of Swedish housing and welfare politics. Since the 1940s, the Swedish system of public housing provision has been based on a model of public utility housing ( $\mathrm{Sw}$ : allmännyttiga bostäder). It was designed based on principles of universalism to ensure 'good housing for all', as the policy slogan went. By making public utility housing formally open to all - thus rejecting a model of means-tested social housing - the Social Democratic government sought to eliminate slum areas, prevent the future stigmatisation of public rental housing, and secure broad-based support for their policies (Bengtsson, 2006, 2015; Grander, 2018, pp. 80-94). The political economy of housing has since shifted significantly, all but dismantling the 1940s model of public utility housing (Christophers, 2013; Grander, 2017, 2018). Nevertheless, the idea that there should be no selective or particularistic solutions - no social housing, and certainly no slums - remains a politically salient one. As Sahlin (2008) argues, social housing as the slum is the persistent spectre of contemporary Swedish social housing policy (see also Sahlin, 2013). In this context, it is also important to remember that unlike many other European countries that have a tradition of state-sanctioned caravan sites and institutionalised camps for Roma and Travellers, Swedish Roma civil rights activism in the 1950s successfully organised around claims for emancipation and integration into regular housing (Mohtadi, 2012; Ohlsson Al Fakir, 2015). While Roma and Traveller camps were a common sight during the first half of the 20th century, they mostly disappeared in the 1960s and 1970s as more and more people got access to regular housing (Ohlsson Al Fakir, 2015). For this reason, Roma camps are seen today as a thing of the past - a shameful past of state racism at that (Persdotter \& Ericsson, 2016).

\section{Nuisance Complaints}

The City of Malmö received over 200 private nuisance complaints about the Sorgenfri camp. The majority of these complaints were addressed directly to the Environmental Administration. Others were forwarded from other administrative units or from individual politicians. The complaints played a direct role in the demolition in that they prompted 
the administration to launch an inspection ( $\mathrm{Sw}$ : tillsynsärende) and exerted continuous pressure on them to resolve the case. ${ }^{44}$ Notably, not all complaints were as crude as the one I quoted at the beginning of the chapter. The administration received a number of much less passionately worded complaints from individuals who either lived or worked nearby the settlement and who claimed to be directly experiencing nuisances (Sw: olägenheter) emanating from there. The following two quotes are exemplary of this type of complaint:

I work next door to the EU migrants' camp. I cannot take it any longer. The smoke from their fires goes straight into our offices, and tonight I had such a headache I could hardly sleep. I feel it in my eyes and in my throat. I have to be here 8 hours a day, 5 days a week, and I cannot move. If you cannot help me, where do I turn? (complaint to the City of Malmö, February 18, 2015) ${ }^{45}$

We own the properties [next to] the EU migrants' camp. Our tenants and us are starting to have problems with the garbage that is accumulating at the property Brännaren 19 . They attract large numbers of birds and rats that then come to visit our properties. Completely understand that this is a sensitive issue, and a difficult one to resolve. But as it stands, a large societal problem has landed in our neighbour's yard. What are you and the municipality doing? (complaint to the City of Malmö, February 9, 2015)

These complaints raise concrete, immediate, and local nuisance concerns (i.e., garbage, pests, and smoke), highlighting a direct conflict between the squatters' use of the space and the ability of others to use that same

\footnotetext{
${ }^{44}$ The Environmental Administration allows members of the public the opportunity to report environmental concerns and file complaints if they experience a nuisance or spot some other type of environmental issue. The authorities have a duty to investigate such complaints and take corrective action if they deem the issue in question to be in violation of the Environmental Code.

${ }^{45}$ Original: Jag jobbar ... granne med EU-migranternas läger. Jag står snart inte ut längre. Röken från deras eldar går rakt in i våra lokaler och i natt har jag haft sådan huvudvärk och har knappt sovit en blund. Känner av det $\mathrm{i}$ ögon och luftvägar. Jag måste vara här 8 timmar om dagen, 5 dagar i veckan och kan inte flytta på mig. Om ni inte kan hjälpa mig vart vänder jag mig?

${ }^{46}$ Original: Hej, Vi äger fastigheterna [intill] EU-migranternas läger. Våra hyresgäster och vi börjar få problem med soporna som ansamlas på fastigheten Brännaren 19. De drar till sig stora mängder fåglar och råttor som sedan besöker våra fastigheter. Har full förståelse för att frågan är känslig och mycket svår att lösa. Men som det är nu har ett stort samhällsproblem landat hos vår granne. Vad görs från er och kommunens sida?
} 
and surrounding spaces. Strictly speaking, this is what nuisance law is about: it governs competing uses of land and property. As I will discuss later in this chapter and in the subsequent one, the argument that the settlement interfered with others' use and enjoyment of land and property, as well as with public interest, was an important aspect of the legal rationale and justification for its demolition. Notably, although the squatters were unlawfully occupying a privately owned property, many of the complainants either ignore the question of formal ownership altogether or treat it as secondary concern. Instead, they focus on the alleged impropriety of the settlement. For instance, at least three different people wrote to the Environmental Administration to complain that the squatters were preventing local youth from using the informally built skateboard ramp located on the vacant lot:

There were four youth who came to the skateboard ramp today, and who stopped to witness the devastation. There are piles of faeces from the people in the 'camp' in and around the skateboard ramp, as well as urine. I am attaching a photo. It is horrible that our youth, who have spent so much time building their skateboard ramp, should have it destroyed and abused by these immigrants who, on top of it all, are trespassing on land that is privately owned. It pained me to see these youth bike away from the site, with their skateboards under their arms, gazing at their skateboard ramp. Every day, year around, the skateboard ramp is used by youth doing sports or taking photos, dancers who are being filmed, and so on. That is a nice addition to the vacant lot. (complaint to the City of Malmö, February, 12, 2015) ${ }^{47}$

In this complaint, the squatters' 'destruction' and 'abuse' is juxtaposed with the skateboarders' 'nice' use of the vacant lot. Although both groups were technically trespassing, the skateboarding youth are extolled for improving the vacant lot and represented as its rightful occupiers ('their

\footnotetext{
${ }^{47}$ Original: Det kom fyra ungdomar till skateboardbanan idag, de stannade verkligen upp och såg bedrövelsen. Det ligger otroligt många högar av avföring från människorna i 'lägret' runt och i skateboardbanan, även urin. Foto bifogas. Det är fruktansvärt att våra ungdomar som lagt ner så mycket tid på att bygga sin skateboardbana ska få den fördärvad och kränkt av dessa indvandrare som dessutom intagit en tomt som en privat fastighetsägare ägare. Det gjorde ont i mig när jag såg dessa ungdomar cykla därifrån sakta med skateboarden under armen och blickade in på sin skateboardbana. Varje dag, året runt är skateboardbanan besökt av ungdomar som vill sporta lite, fotografera, dansare som blir filmade osv. Det är ett trevligt inslag på ödetomten.
} 
skateboard ramp'), worthy of empathy ('it pained me to see'). Meanwhile, the squatters are accused of having caused devastation and of depriving more respectable users of access to the place.

\section{Re-scaling Local Concerns and Intimate Aversions}

Significantly, the overwhelming majority of the complaints regarding the Sorgenfri camp do not stop at identifying the settlement as a local, sitespecific nuisance. Many also make direct links between the dirty, disorderly, and unsightly conditions in the settlement and the squatters' supposedly illegitimate presence in the country as a whole, framing both as a threat to the integrity and security of the Swedish welfare state and society. The complaint which I included at the very beginning of this chapter - the one that suggested that the squatters 'only create problems for us honest Swedes' and 'should be grateful that they were not shot' is a case in point. The following complaints are not as crude in terms of their tone, but they articulate a similar standpoint:

Just between us, we cannot have it like this, lots of 'shantytowns' in our parks and green areas that just keep multiplying. Criminality is increasing as well, people abuse and burn down their camps, they charge each other for the best [begging] spots, etc. Besides, other groupings of these people engage in such activities as burglary. It cannot continue like this if we are to have a functioning welfare [society]. Our country must take care of its own citizens, it is different in war-affected countries where people flee from their lives. (complaint to the City of Malmö, March 7, 2015) ${ }^{48}$

I was horrified to find out from the newspaper that the eviction of the beggars has been interrupted. It makes me irritated and terribly frustrated to see how, every day, Malmö is transformed from a nice and pleasant city into a social problem city and in some areas to a shantytown. ... At some point we have to put down our foot in Malmö and Sweden. We cannot be the world's conscience and take care of

\footnotetext{
${ }^{48}$ Original: Oss emellan kan vi inte ha det såhär, massor av 'kåkstäder' i våra parker och grönområden som blir fler och fler. Sedan ökar även kriminaliteten, man misshandlar och bränner ner deras läger, man kräver pengar av varandra för bästa platsen osv. Plus att andra grupperingar av dessa människor ägnar sig åt saker som att göra inbrott. Såhär kan det inte fortsätta om vi ska ha en fungerande välfärd. Vart land måste ta hand om sina egna medborgare, annat är det i krigsdrabbade länder där folk flyr från sina liv.
} 
everyone who has difficulties in their countries. Return the beggars to their home countries and let these countries take care of them. ... Put your foot down now and save Malmö from doom. (complaint to the City of Malmö, April 29, 2015) ${ }^{49}$

Evoking a dystopian vision of spiralling crime and disorder - of impending 'doom' - both of these complaints make the case that the state's responsibility is and should be limited to 'its own citizens', that 'we cannot take care of everyone'. Again, this is a widespread viewpoint in the era of the migration crisis (cf. Barker, 2018). ${ }^{50}$ What is noteworthy about these two quotes is that they establish a chain of association between the immigration of 'these people' and the spread of shantytowns and various crimes. My point is not that such connections objectively do not exist. If we are to trust the reports of the Swedish police authority, they do (Polismyndigheten NOA, 2015). Rather, I wish to highlight how these complaints identify the very presence of 'these people' as the root cause of various social ills rather than as a symptom of their active marginalisation. Consequently, their removal - not just from the specific settlement but from the country as a whole - is presented as the only thinkable solution. Even when it is explicitly acknowledged that 'these people' are victims of crime ('people abuse and burn down their camps'), the reasonable response is said to be repatriation.

Another way of looking at the situation would be to say that the conditions of the squatters of the Sorgenfri camp, and the immediate reason why they were staying in a makeshift settlement without access to water or adequate sanitary facilities, was that there were few other options available to them. Some complainants did precisely that. Instead of

\footnotetext{
${ }^{49}$ Original: Läste med förskräckelse i tidningen att avhysningen av tiggarna har avbrutits. Det är med irritation och fruktansvärd frustration som jag ser att Malmö varje dag förvandlas från en fin och trevlig stad till en socialproblemstad samt i vissa områden till en kåkstad. /.../ Någongång måste vi i Malmö och i Sverige sätta ner foten. Vi kan inte vara världens samvete och ta hand om alla som har det svårt i sina länder. Skicka tillbaka tiggarna till sin hemländer och låt dessa ta hand om dem. /.../ Sätt ner foten nu och rädda Malmö från undergång.

${ }^{50}$ To be sure, the first of the two quotes concedes that it is 'different ... when people flee for their lives'. In other words, some migrants are more deserving than others.
} 
identifying the squatters as culprits of the situation, they called into question the failure of the authorities to provide adequate and appropriate accommodation. The following message, which was addressed to the Social Democratic chairperson of the Environmental Committee, is a case in point:

[T] hat you, as social democrats, are chasing people around the city rather than making sure they have good [living conditions] is a disgrace to the legacy of social democracy. All the things you did for poor people in the $50 \mathrm{~s}$ to $70 \mathrm{~s}$, when you demolished bad settlements [Sw: dåliga bosättningar] and built new, good housing. Have you forgotten about that? Have you forgotten that mindset? That you are throwing people around [Sw: slänger runt människor]! It is not worthy of a democratic state! (complaint to the City of Malmö, April $23,2015)^{51}$

Nevertheless, with few exceptions, the nuisance complaints regarding the Sorgenfri camp attribute the derelict conditions of the settlement to the behaviours of the squatters themselves as proof of their Otherness and supposedly inferior moral character. Instead of locating the source of the problem in the existing social order (e.g., in the inherent exclusions of the welfare state), the complaints shift the blame onto the "vulnerable EU citizens' as abject outsiders (cf. Hansson, 2019, pp. 449-453). Structural factors and explanations are eclipsed by essentialising culturalist ones. Consider the following excerpt:

From an environmental point-of-view, their living in 'shantytownlike' accommodation and the way they litter and light fires is something that $\mathrm{I}$ as a Swedish citizen would have never even considered doing. (complaint to the City of Malmö, March 3, 2015) ) $^{52}$

\footnotetext{
${ }^{51}$ Original: Att ni som socialdemokrater inte i första hand arbetar för att dessa människor ska ha det bra så sa ni istället jaga runt dom i staden. Det är verkligen en skamfläck på hela det socialdemokratiska arvet. Allt det som gjorde för fattiga under 50-70-talen när ni rev dåliga bosättningar och byggde nya bra bostäder. Har ni glömt det? Har ni glömt den inställningen? ;am slänger inet runt människor på det sättet som ni gör nu! Det är inte värdigt en demokrati!

${ }^{52}$ Original: Ur miljösynpunkt är deras boende i ‘kåkstads' liknande boenden och deras sätt att skräpa ned och elda med något som jag som svensk medborgare aldrig hade funderat på.
} 
While many complainants stop at describing the squatters as 'beggars' or 'immigrants', several complaints make metonymic associations between the squatters and excrement or 'filth' (Sw: smuts), and three complaints either explicitly or implicitly compare the squatters with animals specifically dogs, parasites, and pigs (e.g., 'their pig-like behaviour'). One complainant states,

I have two dogs. Every night we take a long walk through the city, and we usually return home along Nobelvägen. On several occasions, I have seen people peeing and pooping in there. There are several hundreds of them who live there, and all of them relieve themselves multiple times a day. This is a sanitary nuisance and can spread infections. It feels absurd to be walking along the other side of the fence, picking up dog poop. (complaint to the City of Malmö, April $19,2015) \cdot{ }^{53}$

Others use a more overtly racialising language, attributing the derelict conditions of the settlement and various other problems commonly associated with 'vulnerable EU citizens' to their presumed Roma ethnicity and way of life. Consider, for instance, the following excerpt.

Again, I would like to draw your attention to what will happen if you do not put a stop to begging and these so-called Swedish EU migrants. In my language, as well as in theirs, they are called gypsies [Sw: zignerare]. Many women are pregnant. What happens to their children? In other countries, they are begging together in large 'good' families. If we take care of one child, then we have to take care of all. If a family is given a home, then we have to give accommodation to everyone. What will happen during a hot summer? With shit everywhere! Who should account for all the costs they bring about? I do NOT want to pay! ... It is terrible that our grandchildren will not have the childhood we once had in this country that used to be the world's best country. Signed, A desperate citizen who only pays, contributes and does not have any rights. PS. Prohibit begging now!

\footnotetext{
${ }^{53}$ Original: Jag har två hundar. Varje kväll går vi en lång promenad genom staden. Vi brukar återvända hem via Nobelvägen. Vid flera tillfällen har jag sätt människor kissa och bajsa där. De är flera hundra, och de uträttar sina behov flera gånger om dagen. Detta är en sanitär olägenhet och riskerar att sprida infektioner. Det känns absurt att gå längs andra sidan av staketet och plocka upp hundbajs.
} 
While invoking the trope of a demographic threat, it makes a direct link between the arrival of EU migrants (whom the complainant insists on calling by the pejorative term zigenare), increased welfare spending, and 'shit everywhere'. ${ }^{55}$ In doing so, it repeats and reinforces the longstanding and deeply dehumanising stereotype of the 'dirty gypsy'. ${ }^{56}$

\section{'The law apparently does not apply to EU migrants'}

If the overwhelming majority of the nuisance complaints expressed strong aversions and antipathies towards the squatters, many also directed anger and frustration towards the authorities. As they would have it, the municipality had failed to take decisive action against the squatters: they were being unduly lax, giving the them preferential treatment. For instance, the complaint which I cited at the very beginning of the chapter derided the authorities for being all too lenient, implying that they had been 'coddling' (Sw: fjäskat för) the squatters.

The Environmental Administration made two unsuccessful attempts to evacuate and demolish the Sorgenfri camp in the late winter and early spring of 2015. Following each such attempt, they received responses from people who were dismayed by the situation. Many raised objections that the squatters were being 'let off the hook' and given an exemption because they were 'migrants', and some voiced concerns about 'reverse

\footnotetext{
${ }^{54}$ Original: Jag vill återigen göra er uppmärksamma på vad som ska hända om man inte sätter stopp för tiggeri och dessa sk på svenska EU-migranter. På mitt och deras språk kallas de zigenare. Många kvinnor är gravida. Vad händer med deras barn? I andra länder tigger de tillsammans i stora 'fina' familjer. Tar man hand om ett barn måste vi ta hand om alla. Får en familj boende måste vi ge boende till alla. Vad kommer hända under en varm sommar? Med skit överallt! Vem ska stå för alla kostnader de orsakar? Jag vill INTE betala! /.../ Det är fruktansvärt att våra barnbarn aldrig får den uppväxt vi alla en gång fick i fd världens bästa land. Signatur En desperat medborgare som bara betalar, bidrar och inte har några rättighter. PS Förbjud tiggeri nu! ${ }^{55}$ The trope of a demographic threat refers here to the fear that a minority group with grow to out-number the
majority population, thus threatening the ethnic identity of a given country.

${ }^{56}$ This stereotype is often mentioned in the literature on the stigmatisation and marginalisation of Roma and Traveller communities historically and today (e.g., Clough Marinaro, 2014b; Cretan \& Powell, 2018; Ivasiuc, 2015; Lucassen, Willems, \& Cottaar, 1998; Montesino, 2002; Solimene, 2011; Tervonen, 2010).
} 
discrimination'. As one complainant put it, 'just because you are an emigrant, it cannot be legal/allowed to do whatever you want' (complaint to the City of Malmö, March 3, 2015). The following two complaints express a similar viewpoint:

As concerns the park occupants' [presumably this refers to the squatters in Pildammsparken] tendencies to relieve themselves completely openly and just about anywhere they want, well, it is a criminal act that [should] render police intervention. Ordinary citizens who 'strike a seven' [i.e., urinate] in the park would immediately be fined. You have apparently abolished equality before the law. Very strange that the police have not already thrown out those who have moved in and created a veritable garbage heap on the private lot at Industrigatan/Nobelvägen. (complaint to the City of Malmö, March 1, $2015)^{57}$

[The law] apparently does not apply to EU migrants. If you are unsure of what I mean, then take a trip to Nobelvägen/Industrigatan where they have been allowed to do what they want for over two years.... If you are serious about applying the law you should be on their case about it. But you are not, which might be interpreted as a sign that littering is ok. If it is the case that these laws apply only to some, then it is discrimination. So, my interpretation is that as long as their littering is okay, I also do not have to pay for expensive waste collection/sorting. (complaint to the City of Malmö, March 27, $2015)^{58}$

The idea that 'vulnerable EU citizens' (or 'EU migrants') were somehow shielded from law enforcement was widespread in 2014-2016. It was repeated again and again by representatives of the property owners' association Fastighetsägarna (e.g., McCormac, 2015; Öhrström, 2016)

\footnotetext{
${ }^{57}$ Original Beträffande parkockupanternas benägenhet att göra sina behov helt öppet och var som helst så är ju bara det en brottslig handling som renderar polisingripanden. Vanliga medborgare som slår en sjua i parken skulle omedelbart bli bötfällda. Likhet inför lagen har ni tydligen avskaffat. Mycket märkligt att polisen inte redan slängt ut de som har flyttat in och skapat en veritabel sophög på den privata tomten vid Industrigatan/Nobelvägen.

${ }^{58}$ Original: [Lagen verkar] besvisligen inte gälla EU-migranter. Är du osäker på vad jag menar så ta en tur till Nobelvägen/Industrigatan där de fått göra som de vill i över 2 år. [...] Ni borde ju om dessa lagar ska följas vara på dem dagligen med blåslampa. Men det är ni inte vilket kan tolkas som att nedskräpning är helt ok. Eller gäller dessa lagar bara vissa är det ju diskriminering. Så min tolkning är att så länge deras nedskräpning är okej behöver jag inte heller betala för dyr sophämtning/källsortering.
} 
and in mainstream media, including in a much-talked-about episode of the investigative TV show Uppdrag granskning.59 While a detailed analysis of media discourse is beyond the scope of my study, I mention it here to illustrate that the 'nuisance talk' of the complaints, although it was often quite crude, echoed messages that you would hear on public service television and in established news media (for an analysis of media/public discourse regarding 'the settlement issue', see Hansson, 2019, pp. 449455). The episode in question aired on September 25, 2015, about a month before the demolition of the Sorgenfri camp was announced, and included a full one-hour feature on the 'settlement crisis', focusing on the case of the Sorgenfri camp. The episode fixated on the sanitary situation in the settlement, giving one close-up shot after another of faeces, garbage, and oil-leaking cars while showing the squatters as they were arguing with each other and with the camera team in Romanian. As the show did not make the effort to have the squatters' statements translated and subtitled, what ended up being served was an hour of prime-time TV where activists, public officials, police officers, and the manager of the adjacent cemetery talked about the squatters and the problems of the settlement, while the squatters themselves were effectively muted. The spin on the story was that 'society was looking away' in the face of a growing law and order crisis and that a 'bureaucratic short-circuit' was preventing the authorities from evacuating and demolishing the settlement. In particular, the Prime Minister, Stefan Löfven, and his government were called into question for failing to take action against the unauthorised settlements of 'vulnerable EU citizens'.

To be sure, the show received some criticism. For example, the journalist Mikael Olsson Al Safandi (2015) called it 'the worst example of tendentious journalism [he] had ever seen' and asked why Swedish media, which reported critically on the expulsions of Roma EU citizens

\footnotetext{
${ }^{59}$ Uppdrag Granskning is a longstanding investigative journalism show with a viewership of about 800,000 people (about one-tenth of the total population), and a host (Janne Josefsson) who is known for his confrontative and uncompromising style of reporting (Hanson, 2017). The complete manuscript for the episode is available here via the following URL, and on file with the author: https://www.svt.se/nyheter/granskning/ug/referens/ug-referens-nar-samhallet-tittar-bort.
} 
from France and Italy, would go to such lengths to justify similar events at home. However, many news outlets repeated the messages conveyed in the Uppdrag granskning episode. For instance, immediately after it aired, the local newspaper Sydsvenskan published an editorial with the headline 'The law must apply equally to all. Even vulnerable EU migrants':

Equality before the law needs to be maintained. What is not allowed for Swedish citizens cannot be allowed for foreign citizens. EU migrants should not be allowed to build camps in parks or green spaces, not on privately owned land. ... The government steers the country it says in the Instrument of Government, one of the country's constitutional laws. The handling of the migrant camps says something different. (Lagen måste gälla alla. Även utsatta EUmigranter., 2015).

As I will explain in detail in the following chapter, the argument that the law was not being applied equally was not completely baseless. Various practical circumstances did make it complicated to evict groups of 'vulnerable EU citizens' through the regular civil law procedure. However, the technical-legal reason why the Environmental Administration in Malmö was unsuccessful in their efforts to do away with the Sorgenfri camp was not because they did not try, nor because they somehow gave the squatters preferential treatment. Quite the opposite, actually. Nevertheless, the idea that 'vulnerable EU citizens' were being subject to a form of 'positive discrimination' at odds with the rule of law - a 'problem' that could only be resolved through stricter law enforcement - was constructed in public discourse as a widely agreedupon truth. As we will see in the next chapter, the notion of equality of treatment also came to form a key element of the official justification the demolition of the Sorgenfri camp.

\section{'Should We Accept This Standard of Living?'}

Having shown how the many nuisance complaints that were addressed to the City of Malmö regarding the Sorgenfri camp described the settlement and its inhabitants as defiling and threatening of order and security, I turn now to consider how municipal politicians and public officials depicted 
the settlement and reasoned about its eventual demolition. Admittedly, there were those municipal politicians who were outright hostile towards the squatters. For example, a local representative of the nationalist party Sverigedemokraterna, Magnus Olsson, described the encampments as 'completely unacceptable' and called for their speedy demolition. The following is a quote from an op-ed he wrote for the local newspaper Skånska dagbladet, published in January, 2015:

\begin{abstract}
Our vision of a safe Sweden is completely in contrast with what we are seeing today, especially in Malmö where the problem at hand is particularly pronounced. As Sweden Democrats, we cannot passively stand by and watch as foreign beggars are building shantytowns in our parks and begging for money from our residents, all the while not making the slightest effort to become part of Swedish society. If they have the intention of staying in Sweden and in Malmö, then they also need to do their best to get a job and integrate. If they are coming here to build camps in our parks, beg in our streets and loiter then it is our opinion that it is better for them to go back to their home country. (Olsson, 2015).
\end{abstract}

The municipality's response to the settlement was mainly rationalised in a language of benevolent care for the squatters and as a means to ensure equality of treatment. Indeed, a key point I wish to make is that while many of the nuisance complaints pathologised the squatters, attributing the derelict conditions in the settlement to the behaviours of the squatters themselves as proof of their essential Otherness and inferior moral character, municipal politicians and officials turned this logic around to argue that the settlement itself was really the source of the problem and that they could not allow the squatters to continue to be subjected to such undignified conditions. In other words, rather than identifying the squatters as the problem, they categorised the settlement as a problem for the squatters. As such, the demolition was ultimately justified as a means to protect the squatters while also enforcing established standards of sanitation, health, and safety for the benefit of the public at large.

In early October, 2015, a couple of weeks before it was announced that the Sorgenfri camp would finally be demolished, I met with one of the municipality's lawyers who was involved with the case. I asked them to 
talk about an accusation that the squatters and their allies were making, namely that the City of Malmö was treating them 'like garbage'. My interviewee responded at length:

There are a lot of accusations flying around. People claim that we are calling the residents 'garbage'. That is not correct, we really are not doing that. They say that poverty gives rise to environmental problems. Well, that is correct. The largest environmental problems today are localised to the poorest regions of the poorest countries. You ask me, where is Europe's garbage heap? Well, it is in Africa. Poor countries are absorbing all of our electronic waste. So yes, this is not a controversial statement: poverty is an environmental problem. Poverty gives rise to littering, and poverty is a health problem - I think everyone agrees on that point. But to say that people are garbage, or insinuate that the municipality is using the Environmental Code to get rid of people, well those are false accusations. We are doing our job, carrying out an inspection because according to the Environmental Code that is the only way we can ensure a sustainable future.

This is altogether a very sensitive matter, and I have to admit, we are scared. It is such a balancing act, you know? We want to do our job, and yet we are so freakin' scared that we might be triggering, you know, these dark forces that prefer to think that we are their best friends. I want for the law to be followed. All housing needs to meet the requirements of the law, and that is ultimately so that we might protect those living there. Poor people should not have to accept to live in shantytowns because then we are back to the year 1875 when the public health authorities were first established. We have had housing inspections since then, and we managed to get rid... Well, it took a hundred years to get rid of the worst... and then it came back with slumlords who want to make quick money and all of that.

I have to admit, I feel torn. The law exists to protect the most vulnerable, that is what the law is for. No one should have to live like that. ... In this particular case, how long should we wait before we act? Should we make an exception? If we do make an exception, are we doing it because they are Roma or Romanians, or because they are poor? Or why are we making an exception from our existing regulatory frameworks - because they are not Swedish citizens, or because they are not formally registered as residents here in Malmö? Is it really ok to live like that just because you are not a citizen? Is it ok for their children to live like this? Is it ok for other homeless individuals to live like this? Is it ok for all poor people who lack access to housing to live like this? If so, well, then everything falls apart - all 
legal protections are all of a sudden meaningless. And then you need to ask yourself: should we intervene when people are living in derelict conditions in basements with mould growing on the walls? I don't know, should we? Why are some people deserving of protection and not others? Why should the law apply in certain situations and not in others? (interview with lawyer at the City of Malmö, October 8, 2015)

The lawyer's reflections speak to a number of the professional ethical dilemmas facing the administration. How should they relate to 'dark forces' such as the vigilante groups that target the settlements of 'vulnerable EU citizens'? What should they do about the fact that a group of people are living under conditions that clearly do not meet the requirements of the of the law, given that they have virtually no access to alternative accommodation in the city? Should they make an exception and allow them to remain on the site, and if so, on what basis? If they did, what would this mean for their mandate and responsibility to uphold certain minimum standards of housing and 'protect the most vulnerable' against slumlords? Would the law then 'all of a sudden be meaningless'? Would 'everything fall apart'? These are weighty questions. Without trivialising them, I would suggest that many of the dilemmas that the lawyer speaks of are, in fact, inherent to environmental nuisance governance. They stem, in part, from the fact that the Environmental Administration is limited in the regulatory tools they can rely on to address problems of poor-quality housing. Indeed, the tools of environmental nuisance law are mainly coercive and prohibitive (Bro, 2000; Valverde, 2011). The Environmental Administration has little power to implement positive technologies. They cannot, for example, provide the squatters with better sanitary facilities or guarantee that they will be rehoused. Therefore, I would argue that the lawyer's qualms tell us something about the implications of the scalar allocation of the issue of street-homelessness among 'vulnerable EU citizens' to the local level: It points to some of the paradoxes that inevitably arise when the authorities attempt to deal with such a multi-layered issue with the means afforded to the municipal authorities, and to the effects of funnelling it through the awkward machinery of environmental nuisance law. I discuss this in more detail in the following chapter. 
Crucially, the lawyer ultimately rationalised the decision to demolish the Sorgenfri camp as a means to ensure equality of treatment. This was necessary to guarantee the rule of law and maintain standards of environmental and public health protection. The demolition, they argued, was ultimately in the best interest not just of the squatters but of poor and homeless people more generally. The city's red-green political leadership took a similar standpoint and drew on a language of equality before the law. Notably, their rhetoric also revolved around the need to uphold the principles of the universalist system of social housing and welfare provision. Consider, for instance, the position of the then Social Democratic municipal commissioner ( $\mathrm{Sw}$ : kommunalråd) for social affairs, Carina Nilsson. In November 2014, almost exactly a year before the demolition of the Sorgenfri camp, she participated in a public debate with members of the volunteer network Solidarity with EU Migrants. The volunteers wanted to know why the City of Malmö would not provide the settlement with basic sanitary facilities like a couple of portable toilets and garbage collection services. Nilsson replied,

I barely know where to start... this is the most difficult situation I have ever had to deal with. It affects us all, every time we walk past a beggar. Should I give them some spare change or just continue walking? We have built a welfare society and pay taxes for everyone to have some basic protection, so that no one should have to beg. And then we suddenly get this situation, because other countries have not done anything. ... I can understand that it is a tempting thought [to provide the residents of the Sorgenfri camp with a garbage container and portable toilets]. Practically it would not be difficult to do so. The difficulties arise once they are there. What do we do once we have built a shantytown? What will be the next step, should we accept this standard of living? ... When the municipality acts it has to do so in accordance with certain standards and principles. Is it right that people should live in tents with porta-potties? Should we sanction it? For me, this is not an easy question. (Carina Nilsson, the City of Malmö municipal commissioner for social affairs, quoted in Pedersen, 2014)

Much like the lawyer's reflections, Nilsson's response was characterised by a sense of ambivalence. On the one hand, the conditions in the settlement were deplorable, clearly at odds with the ethos of the universalist system of welfare provision her party, the Social Democrats, 
once helped establish. On the other hand, putting out a couple of portapotties and a garbage container would mean that she and the rest of the red-green municipal leadership endorsed a substandard form of housing. This, too, would be a diversion from the dominant model of housing and welfare provision. A similar sentiment was echoed by the Social Democratic chairperson of the city's environmental committee, Carina Svensson. On October 27, 2015, she appeared at a press conference to announce the committee's decision to demolish the Sorgenfri camp. Stating that it was 'the most difficult decision that she had ever had to make', she continued to explain,

We cannot let it be acceptable that people live in huts, in tents ... where there is no access to water, to no access to the sewage system, to hygiene and so on. In Sweden, we have a law that says that everyone should have access to good, dignified housing - and it is not dignified to live as they do [in the settlement]. We also have a principle of equality, and this means that all human being should be able to live in acceptable conditions, and it is not acceptable to live as they do on Brännaren.

Invoking the memory of the late Roma civil rights activists Katarina Taikon and her struggle for the emancipation of the Swedish Roma, Svensson continued,

Fifty years ago, we decided here in Sweden - and this was in connection with Katarina Taikon - that it is not allowed and we will never again accept that people live like this, that people live under such conditions. Back then, we decided that the law should be the same for everyone. We cannot say today that we are going to go back in time to fifty years ago and say that it is allowed for people to live like that.

Here, the fundamental paradox was, of course, that the demolition of the settlement left its former inhabitants in an even more vulnerable situation - on the street, with minimal access to any form of temporary or longterm shelter. If the demolition of the settlement went some way to ensure that no one should have to live in makeshift huts and tents, it did so to the direct detriment of those most immediately affected by it. Svensson invokes the core liberal principle of equality of treatment, suggesting that this principle alone is enough to guarantee everyone's access to 'good, 
dignified housing'. At the same time, both she and Nilsson are silent on the fact that the squatters by virtue of their citizenship status and poverty are effectively excluded from accessing such housing.

It would be easy to dismiss Svensson's and Nilsson's statements as a smokescreen for a more sinister agenda. However, I believe that to do so would be to miss their deeper significance and the reason why they have such considerable political traction. They reflect what is arguably a salient attachment to a certain vision of Sweden as a country that once and for all eradicated poverty and its various manifestations: shantytowns, slums, and begging. They also signal the persistent contradiction at the heart of the welfare state project: the fact that it is organised around norms of egalitarianism and universalism, promising good housing and welfare to all, while at the same time being fundamentally premised on the exclusion of non-members. Sociologist Helena Holgersson (2011) suggests that the flipside of the commitment to egalitarianism and universalism that marks the Swedish welfare state is a deep-seated resistance to the idea of differential rights (pp. 85-86). As such, the ambition to guarantee everyone the same sets of rights translates sometimes into a defence for the outright denial of rights to various categories of irregular migrants (Barker, 2017; Nielsen, 2016). Against this backdrop, we might understand the simultaneously discursive and material positioning of the squatters as a kind of abject outsiders (and 'out of place') as an effort to expel that which threatens not just the everyday order of the city but also the integrity and legitimacy of the socio-political and normative order of the Swedish welfare state (cf. Bäckström et al., 2016; Barker, 2017; Hansson \& Jansson, 2019; Hansson \& Persdotter, 2019).

Svensson's reference to Katarina Taikon is also remarkable. It positions the settlement and its inhabitants as being not just 'out of place' but also 'out of time' in the sense that they are described as an anachronism: something that belongs properly to a time before the emancipation of the Swedish Roma in the 1950s ('we cannot say that we should go back in time to fifty years ago'). As previously mentioned, there are strong continuities (as well as differences, of course) between the present-day government of 'vulnerable EU citizens' and the treatment of Roma and 
Traveller groups in the 20th century (see argument in Ericsson, 2015, pp. 247-248; Persdotter \& Ericsson, 2016). Katarina Taikon herself was at the forefront of a movement in the 1950s-1970s that challenged the exclusion of the Swedish Roma from citizenship and regular housing and was an outspoken critic of the then widespread practice of routinely and cyclically evicting Roma tent encampments. She also organised actively for Roma migrants from around Europe to be granted asylum in Sweden (see Mohtadi, 2012; Selling, 2013). However, Svensson uses the memory of this movement and its struggle for expansion of and inclusion into citizenship to justify an exclusion from citizenship in the present. It positions the Swedish Roma as 'belonging' to the nation in a way that arguably obscures a complicated and continuing history of discrimination and simultaneously reasserts a notion of bounded nationality and citizenship order.

\section{Concluding Remarks}

In this chapter, I have traced the discursive construction of the Sorgenfri camp and its inhabitants as a nuisance and sanitation hazard. I have done so by analysing the many complaints regarding the settlement that were sent to the City of Malmö, along with statements by municipal politicians and one public official. Starting from the idea that notions of dirt and disorder have long been used to represent residual places and people who are seen to be threatening of the established orders, I attempted to delineate the 'nuisance talk' that circulated in and beyond the complaints. I highlighted several recurrent themes. I showed how many of the complaints described cleanliness and lawfulness as distinctly Swedish virtues ('us honest Swedes'), while the squatters (as 'foreigners', 'migrants', and 'gypsies') were taken to be innately disobedient, and disorderly ('despicable and disrespectful') and thus blamed for their circumstances. I also sought to illustrate how the complaints would frequently slide across scales, linking intimate aversions and local concerns - especially concerns over open defecation - to anxieties about the integrity and security of the Swedish state as a whole. In the second part of the analysis, I turned to consider how the municipal politicians and one public official involved with the case reasoned about the decision to 
demolish the Sorgenfri camp. Unlike the 'nuisance talk' of the complaints, which frequently attributed the problems of the settlement to squatters (and thus identified them as culprits), the municipal politicians instead depicted the settlement as a problem for the squatters. This allowed them to justify the demolition in positive terms as a form of environmental and health improvement and as a means to uphold certain standards of housing, public health, and sanitation.

My analysis resonates with recent scholarship on the securitisation of Roma mobilities in France and Italy that highlights how the putatively unsanitary conditions of makeshift Roma camps have emerged, over the last several years, as one of the main referents of security discourses about the European Roma (Aradau, 2015; Clough Marinaro, 2009, 2014b; Ivasiuc, 2015b; Pusca, 2010). For example, Aradau (2015) suggests that a renewed emphasis on cleanliness and sanitation has shifted the security discourse on Roma in France away from its previous emphasis on crime, bringing a humanitarian turn to the state's rhetoric on and justifications for the evictions of Roma camps. To the extent that the expulsion and repatriation of mobile Roma EU citizens is contingent with their 'evictability' (van Baar, 2017c), discourses of cleanliness and sanitation are an integral aspect of the present-day internal bordering of Europe. In the case of the Sorgenfri camp, we see how a discourse of sanitation is coupled with a rhetoric of equality of treatment to make the case that the settlement needs to be demolished to protect the well-being of the squatters, but also paradoxically to uphold the norms that say that 'everyone should have access to good, dignified housing'. In other words, the settlement is demolished in the name of protecting a principle of equality. I have argued that this should properly be understood as a sociopolitical process of abjection: an effort to expel that which threatens the integrity and legitimacy of the socio-political and normative order of the Swedish welfare state.

Before I wrap this chapter up, I want to offer some final reflections on the racialising dimensions of the material-discursive production of the settlement as an environmental nuisance and sanitation hazard. Indeed, 'dirt' is a thoroughly racialised and racialising category of representation, 
but it is also a 'central modality through which race ... has been lived' (Dillon, 2013, p. 1209). In the context of the modern European colonial project, racial difference was pervasively constructed through the association of whiteness with cleanliness and purity and blackness with notions of dirt and disease (see Gidwani \& Reddy, 2011; McClintock, 1995). As Picker (2017) argues, there is a direct link between colonial logics of racial difference and subordination and the specific racialisation of Roma and Traveller groups in 20th century Europe. In particular, the government technology of the segregated Roma camp was modelled on colonial technologies for maintaining 'purity' and containing the racialised Other (see also Picker et al., 2015, 2019). The relegation and segregation of Roma and Travellers to camp spaces or ghetto-like neighbourhoods, often located on residual lands, have reinforced racialising stereotypes that associate Roma and Travellers with dirt. As the aforementioned Katarina Taikon described in her famous book Zignerare är vi [Gypsies Are Us],

We were herded together like a pack of goats on the outskirts of the city, and assigned to a muddy site with no light and sewer. We had to walk several kilometres to get water, and us children had to defecate out in the open. This was then used as an argument against us, when we wanted a permanent home: we were so pig-like that we did not visit the toilet when we needed to. The fact that there was no toilet was never acknowledged. (Taikon \& Langhammer, 1967)

Contemporary scholars in the field of Romani studies have similarly noted how a cycle of abjection and exclusions works to reinforce the association between Roma and dirt and simultaneously reproduce their marginalisation (Clough Marinaro, 2014b; Ivasiuc, 2015a; Sibley, 1995, p. 68). In the case of the Sorgenfri camp, we see how the squatters are first made dirty through the denial of social assistance and services, garbage collection, sanitary facilities, and access to water (Davis \& Ryan, 2016) and then displaced on account of being dirty. This is a pattern that extends back in time and across Europe. 


\section{LEGALLY REDUCED TO LITTER}

In the previous chapter I discussed the many nuisance complaints that were sent to the City of Malmö regarding the Sorgenfri camp and the responses bypoliticians and public officials involved with the case. In this chapter, I explore what happened when the descriptions of the settlement as dirty and disorderly were translated into administrative and judicial discourse - that is, when the social object of the settlement was categorised in technical legal terms as a 'nuisance'. In doing so, I consider the tangled administrative and legal processes that eventually resulted in the evacuation and demolition of the Sorgenfri camp.

The analysis is divided into three main parts. In the first part, I trace the many ineffective attempts by the private property owner to have the squatters evicted through a civil law eviction procedure. By reviewing the failed efforts to evict the squatters on the basis of a regular civil law eviction procedure, I explain how the conflict over the settlement ended up being 'resolved' through an environmental law procedure. In the second part (beginning with the section 'Features and Effects of Nuisance Governance'), I turn to consider the efforts of the Environmental Administration (Sw: Miljöförvaltningen) to address what they defined as an urgent sanitary nuisance problem on the site of the settlement, and how these efforts eventually resulted in the evacuation and demolition of the settlement. ${ }^{60}$ This part, which forms the bulk of the chapter, explores the

\footnotetext{
${ }^{60}$ The Environmental Administration (EA) is an administrative and operative unit of the municipality with responsibility for environmental management, which includes monitoring and enforcing the Environmental Code locally. The EA is governed by the Environmental Committee (Sw: Miljönämnden) - a committee of elected representatives that decide on the political goals and objectives of the administration and oversee its operations.
} 
detailed workings of nuisance regulations in terms of their legal effects and implications. Drawing on the work of Blomley (2007b) and Valverde (2011), I show how nuisance regulations - by governing through categories of property and space rather than through categories of personhood - tend to deflect rights-based arguments and claims. I argue that, in the case of the Sorgenfri camp, the invocation of nuisance regulations effectively negated the squatters' claims to legal standing, leaving them with few opportunities for any sort of legal recourse. In the third and final part (entitled 'Deflecting rights claims'), I explore the consequences of this in more detail. Based on a review of correspondence between the Swedish government and a number of human rights organisations regarding the evacuation and demolition of the settlement, I outline the criticism that was levelled against the government and authorities and discuss how the government was able to circumvent this criticism and legitimise the evacuation and demolition in positive terms as a means to care for the well-being of the squatters and ensure that standards of cleanliness, health, and safety were maintained for the benefit of the public at large.

\section{Not an Eviction}

My use of the term evacuation, as opposed to eviction, in this context is intentional. ${ }^{61}$ As I explained in chapter four, the Sorgenfri camp was established on a privately owned vacant lot without any authorisation from the owner, Industrigatan i Malmö AB. Trespass (Sw: olaga intrång $)^{62}$ and unauthorised occupation of a private property is generally illegal in Sweden, but for a property owner to have a group of squatters removed requires that they go through a formalised eviction procedure.

\footnotetext{
${ }^{61}$ A note on the translation: the Swedish term used was avlägsnande, which literally means 'removal'. I use the English term 'evacuation' as I believe it more accurately reflects the intention of the decision to 'remove' the squatters from the site in order to protect them from harm. It should be noted that the language of 'evacuation' was contested by several of the activist groups who organised in solidarity with the squatters, who generally insisted on using the language of 'eviction'.

${ }^{62}$ A note on the translation: The Swedish/English Glossary for the Courts of Sweden translates olaga intrång as 'illegal enchroacment'. Here, I have opted for the term 'trespass' as it is a more widely used term in English speaking countries and thus more immediately recognisible to non-Swedish speaking readers.
} 
As a basic due process requirement, the property owner, who files an eviction request, has to provide the authorities with the names and personal information of each individual they wish to have removed. This is usually just a formality, but in the case of the Sorgenfri camp, it proved difficult - not to say impossible - for the property owner to obtain the names of the squatters; therefore, they could not have the squatters removed through a regular eviction procedure. The ultimate decision to demolish the settlement relied instead on the use of environmental law and was justified as a means to do away with the settlement, not because it constituted an unauthorised occupation, but because it had been declared by the Environmental Administration of the City of Malmö as a nuisance to neighbouring communities as well as a major risk to the health and safety of the squatters themselves (Malmö stad Miljöförvaltningen, 2015).

Thus, legally speaking, the eviction was not an eviction. The registrar at the Malmö Police Department made sure to remind me of this when I contacted them in mid-November 2015 with a request to see some documents pertaining to the operation. Over the phone, they explained to me that 'the police never participated in any eviction'. What they did, rather, was 'assist the municipal authorities so as to allow them to execute a decision to demolish the settlement in order to clean the grounds'. The squatters had been evacuated for safety reasons (personal communication, 18 November 2015). From experience, this probably did not make much of a difference to the squatters who saw over 100 police officers arrive in the dim hours of the morning on November 3, 2015, to usher them off the site. Whether they were formally evicted or evacuated, their dwellings were wrecked and they ended up on the street with minimal access to shelter. However, the legal technicalities of the procedure were consequential for how the process unfolded, and they ultimately served to limit the opportunities for the squatters to seek redress and claim a right to resettlement in the aftermath of the 'evacuation'.

The critical Romani studies scholar Huub van Baar (2017c) coined the term 'evictablity' to refer to the unevenly distributed 'possibility of being removed from a sheltering place' (p. 3). The neologism is an explicit 
attempt to radically de-nationalise the concept of 'deportability' (De Genova, 2002) in order to 'articulate that contemporary forms of displacement are not limited to practices that are based on a rigid or crystal-clear distinction of border crossers along the (imagined) lines of the nation-state' (van Baar, 2017c, p. 3). According to van Baar (2017c) 'endless, systematic cycles of forced evictions from place to place' are used by several of the EU member states against mobile Romani EU citizens as a means to effect their 'voluntary return' without having to enact other more costly and time-consuming expulsion procedures (p. 12). The concept is highly relevant to the present case study, but it requires some clarification. From what I understand, the concept of evictability is intended to be a capacious one. Van Baar is not concerned with the nitty-gritty details of eviction law. (And that is, of course, fine.) However, given my focus on the technicalities of law, I would like to make an analytical distinction between eviction and other modes and mechanisms of displacement. In narrow terms, eviction is a formalised process that typically has some built-in safeguards meant to protect the rights of those who are threatened by eviction. Such safeguards are largely absent when camp dwellers are moved on on the basis of more discretionary forms of law enforcement. As I will show in this chapter, there is a sense in which not being formally evictable makes an individual or community even more radically displaceable and precarious (cf. Yiftachel, 2018).

Throughout this chapter, I explore the detailed workings and effects of some of the legal mechanisms that were mobilised by the Environmental Administration as well as by the property owner in their attempts to do away with the Sorgenfri camp. However, I begin with a more theoretically-oriented discussion about the analytical value of attending to the technical aspects of administrative and legal practices.

\section{Law and Legal Technicalities}

In order to better understand how the demolition of the Sorgenfri camp was achieved, as well as how urban social and spatial control is enacted more broadly, I will attend to the technicalities as well as the built-in 
rationalities and resultant effects of the specific regulatory mechanisms at play. In chapter three I discussed breifly the turn, within the field of homelessness policy and urban policing, towards governing the urban poor and various other 'undesirable' subjects through distinctly spatial regulations, such as site-specific anti-begging and anti-sleeping ordinances. In the critical urban theory literature, such regulations are often treated as instruments of larger, external political agendas - be it entrepreneurialism (Franzén et al., 2016; Thörn, 2011), revanchism (N. Smith, 1996), or punitive neoliberalism (Wacquant, 2009, 2014). Similarly, within the critical literature on the spatial exclusion and segregation of Romani communities in Europe, law was sometimes understood as a direct instrument of exclusionary and overtly nationalist and racist agendas, or as an element of the overall securitisation of Romani mobilities. Similar analyses were made also with regards to the demolition of the Sorgenfri camp. For instance, one journalist attributed the demolition to 'cynical urban renewal plans' that perpetuate the dispossession of poor and racialised communities while simultaneously celebrating a sanitised and 'deeply exotifying vision of diversity' (Malm, 2015). ${ }^{3}$ Others argued that the expulsion reflected a 'discriminatory logic' and linked it to the long history of institutionalised racism towards Roma and Travellers in Sweden (see for example Mendez, 2015). There is much to be said to this, and although I am generally sympathetic to such structurally-oriented analyses, I will suggest that it is important to study regulatory mechanisms 'on their own terms' (Sylvestre, Damon, Blomley, \& Bellot, 2015, pp. 1362-1363). If we treat law as a mere instrument or reflection of external ideologies, we risk overlooking the specificity and complexity of legal knowledge and practice.

My methodological approach in this chapter is very much inspired by Valverde's work on the regulation of various forms of urban disorder (2003, 2005, 2009a), including her work on nuisance regulations (2011). Valverde makes a compelling case for studying law by inquiring into the workings and effects of specific legal mechanisms. Drawing on the writings of, amongst others, Michel Foucault, Valverde (2003) adopts a view of legal practice that rejects the dichotomy between appearance and 
reality, between surface and depth - a dichotomy which is common in many realist accounts of the social world, including in the many varieties of Marxist theory (pp. 11-15). Thus, she argues that law is neither a sovereign and rule-bound machinery (the formalist claim) nor a direct reflection, or effect, of social structures and relations of power (the structuralist claim). From this follows a methodological imperative to seek explanations at the level of concrete practices rather than at the level of invisible (or 'hidden') underlying structures, be it capitalism, patriarchy, or - as is perhaps most relevant for my purposes - racist sentiment. Valverde suggests that critically-minded scholars bracket the ontological question 'what is law?' or 'whose ultimate interests do law serve?' to instead foreground more empirically-oriented questions. Specifically, she proposes to ask 'what a certain limited set of legal knowledges and legal powers do', that is, how they work rather than what they are (Valverde, 2003, pp. 10-11). ${ }^{6}$

Attempting to answer the grand questions of 'why' and 'what' takes us down the road of abstraction, and sometimes speculation. We cannot always, or ever, fully know the hidden motives behind a certain decision or practice, nor can we determine the exact causal relationship between a given piece of legislation and more deep-seated social structures. On the other hand, the effects of a given decision or practice can be more directly observed (cf. Rose \& Miller, 2008, p. 11). This is not to say that nothing exists that cannot be seen (the empiricist claim) or that there is no value in structuralist critique or in abstract theorising. However, by focusing on the concrete workings and effects of specific legal mechanisms, one might identify relevant dynamics and rationales that would have been overlooked if one instead had set out to uncover an underlying explanation or 'truth' (Blomley, 2007b; Riles, 2005; Sylvestre et al., 2015). As a method, then, studying effects involves documenting what is already 'on the surface', including that which is commonly overlooked precisely because it is 'so much on the surface' (Veyne as cited in Valverde, 2003. p. 12).

Valverde (2003) notes, in particular, the usefulness of 'documenting the effects of the techniques used ... to organise, sort, classify, relate, and 
explain' (p. 14). In doing so, she echoes Santos' (1987) influential account of law as a map of the social world. Santos' claim is that law is fundamentally a mapping exercise - an ongoing attempt at representing reality that, much like a cartographic map, inevitably distorts this reality, representing it in a way that is necessarily partial, selective, and reductive of real-world complexity (see Valverde, 2009a). Key to Santos' account is the concept of interlegality. This refers to the ways in which different legal orders not only co-exist but also mix and overlap in the same time and space. He emphasises that 'different forms of law create different legal objects upon eventually the same social objects (Santos, 1987, p. 287). In this sense, law also 'creates the reality that fits its application' (p. 288).

As I have alluded to already, dynamics of interlegality mattered a great deal to how the conflict over the Sorgenfri camp unfolded and was eventually resolved. To begin with, the various institutional actors involved in the conflict over the settlement understood and categorised the settlement and its inhabitants differently depending on what type of legal knowledge and rationality they drew on. In the context of the civillaw eviction procedure, which was initiated by the property owner in an attempt to have the squatters removed from the site, the settlement was an unauthorised occupation of privately owned land. Meanwhile, within the framework of environmental law, the settlement was a nuisance and a health and safety hazard - a material collection of litter, smoke, and odours that could potentially cause a fire or a disease outbreak.From the point of view of the human rights organisations that intervened in the case, the settlement was a type of home, and the actions of the authorities represented a possible violation of the fundamental right to housing and home, as well as a breach of other minority and human rights norms.

As I discuss in chapter three, conflicts of law are not just technical-legal issues to be solved by determining which law should take precedent over the other. Rather, the co-existence of multiple and sometimes incongruent sets of regulations set the stage for various actors to strategically mobilise different laws and to shift between different legal registers. The case of the Sorgenfri camp offers multiple examples of this. In the following 
sections, I address the entangled attempts by the property owner, Industrigatan i Malmö $\mathrm{AB}$, and the municipal authorities to have the squatters removed from the site. I observe that the 'illegibility' (Scott, 1998) of the squatters - which derived from them not being registered on the site, or in the country - made it complicated for both parties (i.e., the property owner and the authorities) to take legal action against them: the anonymity of the squatters made them not-readable in the eyes of the authorities, and in turn, this made them difficult to regulate. However, this 'problem of illegibility' was ultimately circumvented by the Environmental Administration as they invoked a specific mechanism in the Environmental Code (i.e., a 'a correction at the expense of the faulty party') that allowed them to treat the settlement entirely as a nuisance rather than as an unauthorised occupation.

\section{Attempts by the Property Owner to Evict the Squatters}

Although one might assume the integrity and scope of private property rights would make it easier to evictsomeone from private property than from public space, the Sorgenfri camp case suggests otherwise. In the Swedish legal system, there are (generally speaking) two main avenues for evicting a squatter settlement from private land: a civil law eviction procedure and a criminal law procedure. If the settlement is situated on public land (e.g., in a park or next to a football-field), the police authorities also have the power to remove the inhabitants on the basis of public order law [CRD, 2017]. In Malmö, the authorities have in some cases invoked the municipal order ordinances, which prohibit camping in the city, to justify the demolition of unauthorised settlements on municipal lands. For example, the demolition of the tent encampment in Pildammsparken, which I mention briefly in chapter four, was carried out with reference to the municipal anti-camping ordinances.

To explain why in the case of the Sorgenfri camp it turned out to be rather complicated for the private property owner to have the squatters evicted through the regular civil law eviction procedure, I need to first establish a few basic facts about this procedure. In legal Swedish, it is called 
'judicial assistance' (Sw: särskild handräckning, literally 'special assistance'). It is regulated in the Enforcement Code (1981:774) (Sw: Utsökningsbalken) and in the Law on Notice to Pay and Judicial Assistance (1990:746) (Sw: Lagen om betalningsföreläggande och handräckning), and it generally proceeds as follows: First, the plaintiff (i.e., the evictor, typically the property owner) files an application for an order to evict with the Enforcement Authority. This is the state debt collection agency, and they deal with a variety of monetary and nonmonetary debt collection requests, including requests for eviction orders. The Enforcement Authority reviews the application and either approves or rejects it. Significantly, the agency only carries out a summary process, which means that they do not examine the validity of the application in terms of its substantial elements. As long as the application conforms to the formal requirements (i.e., the obligatory information is included), it is typically approved and relayed to the respondent party. It is then up to respondent to contest the order. If they do, the case is turned over to the District Court (Sw: Tingsrätten). Otherwise, the Enforcement Authority confirms the order before they ultimately execute it.12

As a general rule, the evictor (the plaintiff) is required to provide the authorities with the personal information (typically the name and civic registration number) of the individuals who they wish to evict (the respondents). For example, a landlord who seeks to have a tenant evicted for falling behind on their rent payments is required to file a request with the Enforcement Authority, citing the personal information of said tenant. The requirement in question is a simple due process protection, a safeguard meant to ensure legal certainty. ${ }^{63} \mathrm{~A}$ tenant facing eviction should have the right to be notified and to appeal their eviction order. Likewise, the authorities should be certain that they are evicting the right person. As it is not within the mandates of the Enforcement Authority to solicit this information on site, the onus is on the evictor to supply the

\footnotetext{
${ }^{63}$ Notably, this due process requirement is not unique to the eviction procedure but applies to most legal processes (see Ch $33 \S 1$ of the Swedish Code of Judicial Procedure, 1942:740).
} 
agency with the relevant information (for more details on this, see DS 2016:17, p. 112).

As I mentioned in chapter four, there were several factors that made it practically difficult for the property owner to obtain information about the inhabitants of the Sorgenfri camp, the primary ones being that there was a steady turnover of people on the site and that none of them were registered on the address. I should note here that the property owner did not file a request to have the squatters removed from the site until after the Environmental Administration notified them they would likely take action against the firm if they did not address the sanitary situation on the site. For about half a year, the firm passively tolerated the settlement, and at one point, they allegedly consented to having a garbage container installed on the site by members of the activist network Solidarity with EU Migrants (interview with Solidarity Activist 2, March 2017). That said, when they did attempt to have the squatters evicted, it turned out to be almost impossible. The property owner filed an initial request for an order to evict on October 20,2014. The application listed two respondents whose names had featured a few weeks earlier in a newspaper article about the Sorgenfri camp. The Enforcement Authority approved the application as per its usual procedure, but when the enforcement officers went to the site to deliver the eviction order, they were informed that the individuals concerned had moved already, and the order was subsequently cancelled.

Four months later, the property owner made a second request with the Enforcement Authority. This time, the company specified the names of four respondents. Not knowing where exactly to send the paperwork, the enforcement officers simply took the envelopes, rolled them up, and pushed them into the holes of the chain-link fence surrounding the settlement. Two weeks later, the property owner received a notice from the Enforcement Authority stating the agency had not been able to identify the respondents on site. On another occasion, an eviction order was cancelled after the Enforcement Authroity found that the names listed therein had likely been misspelled. 


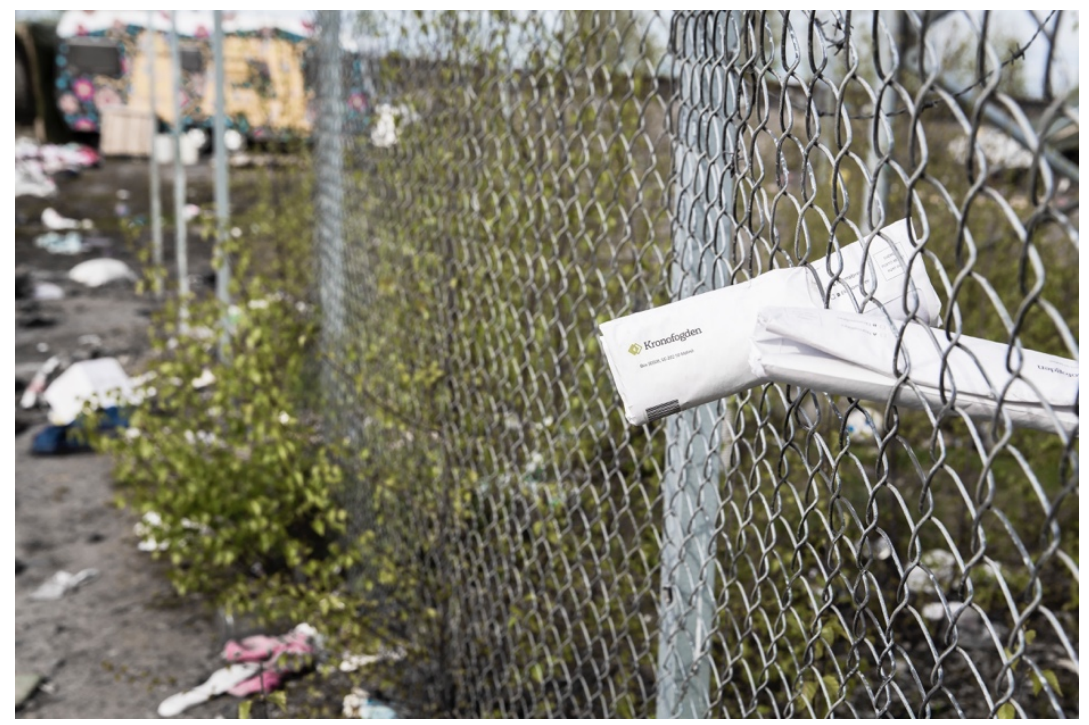

Figure 7. Eviction notice from the Enforcement Authority. This particular picture comes from a different settlement (at Singelgatan). (C) Jenny Eliasson / Malmo Museums

At some point, the property owner also contacted the police and requested their assistance in identifying the squatters. Perhaps due to the contested and controversial nature of the case, the regional police authority put one of their in-house lawyers to work to determine whether or not it was within the mandate of the police to forcibly identify the squatters on behalf of the property owner. Their preliminary conclusion (which was later confirmed by a separate review conducted by the national police authority) was that the police had no mandate to assist property owners in identifying squatters for the purpose of preparing an application to the Enforcement Authority (Polismyndigheten, 2015).

Later, in April, 2015, the property owner attempted the alternative, criminal-law route and filed a report with the police to have the squatters investigated and tried for trespassing (Sw: olaga intrång). However, the police opted to postpone the investigation in order to wait-out the attempts by the Environmental Administration to have the squatters removed 
through a separate environmental law process (interview with the chief operating officer, April 12, 2016).

Altogether then, the property owner was faced with a Catch-22 situation. The squatters were occupying the site without any authorisation or documentation, yet the very fact of their undocumentedness - which derived from them not being registered as residents on the site, or in the country - made it difficult to evict them in full compliance with the safeguards written into Swedish eviction law (cf. Yiftachel, 2009a, p. 243 on 'gray space' as a basis for negotiation and organisation). The dilemma in question was not unique to the Sorgenfri case. Landowners across the country reported having similar difficulties evicting settlements of 'vulnerable EU citizens'. Furthermore, as I will discuss in more detail below, the efforts by the municipal authorities to have the squatters removed on the basis of environmental law revealed similar issues related to the squatters' illegibility. I summarise these efforts below before I proceed to discuss the question of illegibility in some more depth.

\section{Attempts by the Municipal Authorities to Address a 'Nuisance Problem'}

Concurrent with the property owner's attempts to evict the squatters, the City of Malmö's Environmental Administration continued to conduct inspections (Sw: tillsyn) on the site of the settlement. Broadly speaking, the agency is responsibel for monitoring and correcting adverse environmental and health conditions in the city, and it is required to follow up on complaints in this area. Nevertheless, it is widely recognised that environmental inspectors exercise a degree of discretion in carrying out their work and that they probably must do so in order to make the work of enforcement practically feasible. They could not possibly enforce all regulations on all occassions (see Hawkins, 1994 on the 'uses of discretion'). Like most 'street-level bureaucrats' (Lipsky, 1980), they have to balance the formal requirements, as well as the uncertainities of their work, with management directions and oversight and with the expectations and complaints of the public (see Lipsky, 1980, pp. 13-16; Proudfoot \& McCann, 2008). The case of the Sorgenfri camp was a highly contested one, and the Environmental Administration received an 
unusually large volume of complaints regarding the settlement (personal communication with the registrar at the City of Malmö, 2018). It is important to keep in mind this context when we consider the repeated attempts by the Environmental Administration to address the nuisance problem on the site and the legal acrobatics involved in these attempts.

The administration contacted the property owner on at least two occasions (the first time in May, 2014, and the second one in October, 2014) to inform them that there had been complaints about littering on the site and that, by failing to maintain their property, they were in breach of environmental nuisance law. ${ }^{64}$ On February 27, 2015, the Environmental Administration issued an injunction to the property owner, ordering the firm to remove all litter from the site. The injunction came with a fine of 50,000 SEK should the property owner fail to abide by it (Miljöförvaltningen, 2015-02-27). ${ }^{65}$ The Environmental Administration reasoned that because it was not possible to ascertain which individuals were responsible for the littering, the property owner should instead be considered liable and made to abate the issue. They also argued that by neglecting to clean and allowing people to trespass on the site, the property owner had allowed nuisances to occur. The property owner promptly appealed the injunction to the County Administrative Board (Länsstyrelsen), arguing that it was the squatters, not the firm, who were liable for the littering on the site. Citing their back-and-forth with the Enforcement Authority, they also stressed that they had not had a

\footnotetext{
${ }^{64}$ Whether or not it was because they were concerned that their involvement would reflect negatively on them as an organisation is an open-ended question. When pressed on the issue by the media, the chief operating officer of the regional police authority, Mats Karlsson, explained that it was simply a matter of priorities - the police had been overburdened with other, more urgent issues. However, when I interviewed him a few months later, he admitted that he and many of his colleagues had 'felt uneasy about the case' and wary that any involvement on the part of the police would reflect negatively on the institution (interview, April 12, 2016). It appears that the leadership of the regional police authority did not want to attract charges of anti-Roma racism. There is a back story to this: At the time, the regional police authority was still attempting to redeem its legitimacy and reputation after it was revealed that the institution had maintained what amounted to an ethnically based registry of Travellers. To many, the scandal served as a reminder of the deep entrenchment of anti-Roma racism (or anti-ziganism) within the police service and, more generally, within the Swedish state.

${ }^{65}$ The fact that the injunction was addressed to the property owner was not, in and of itself, particularly surprising. From what I understand, this is a common approach when specific individual liability cannot be ascertained.
} 
reasonable chance of preventing the settlement from being established or of evicting the squatters: 'The property owner is simply powerless in the face of the problem' (Law Solution, 2015-03-20). The County Administrative Board (i.e., the court) ruled on a compromise: They upheld the injunction but removed the fine. This meant that the injunction was now legally binding - although still practically difficult for the property owner to abide by. ${ }^{66}$

At this point, the Environmental Administration attempted instead to impose a prohibition against staying on the site (Malmö stad Miljöförvaltningen, 2015). Notably, the reasons given for the prohibition were different from the ones given for the injunction. While initially the Environmental Administration had focused primarily on the issue of littering, they now emphasised that the squatters were at risk of injury and that the prohibition was necessary to abate a range of serious nuisances that mainly affected the squatters' health and well-being. The prohibitionorder came with a list that specifically prohibited any of the following activities on the site:

1. Erecting or storing tents, buildings, trailers, and other devices for accommodation

2. Living and staying overnight

3. Dispersing and storing garbage

4. Defecating on land and facilities

5. Burning solid fuels

Much like the injunction, the initial prohibition order was addressed to the property owner. The firm did not appeal the order, which meant that it gained the force of law, but it was still difficult for the authorities to act on. Some weeks later, the Environmental Administration therefore issued a prohibition addressed collectively to those who were staying on the site. The idea was that this would allow the authorities to remove the squatters.

${ }^{66}$ After receiving notice that the property owner had appealed the injunction, the Environmental Administration filed a notification with the Land and Environment Court, alleging violations of the Environmental Code and asked the court to investigate the matter. Howevr, the prosecutor choose not to take up the case. 
The order was delivered in person by staff from the Environmental Administration to the residents of the Sorgenfri camp, who were notified that they would have four days to evacuate the site before they would be forcibly removed.

With few other places to go, the squatters agreed with the street-law collective Centre for Social Rights (CSR) to challenge the prohibition, and CSR drafted a quick letter of appeal, calling on the County Administrative Board to inhibit the order. The prohibition order was inhibited while the court considered the case; hence, the evacuation was deferred. On the day of the planned evacuation, the squatters and allies instead staged a symbolic protest - demanding an alternative, publicly provided site to stay, covering the Sorgenfri camp with posters of the famous logo of the French SOS Racisme: an open palm with the words Touche pas à mon pote, replaced with the words Nu atingeti casa mea!, Rör inte mitt hem! (En: Do not touch my home!).

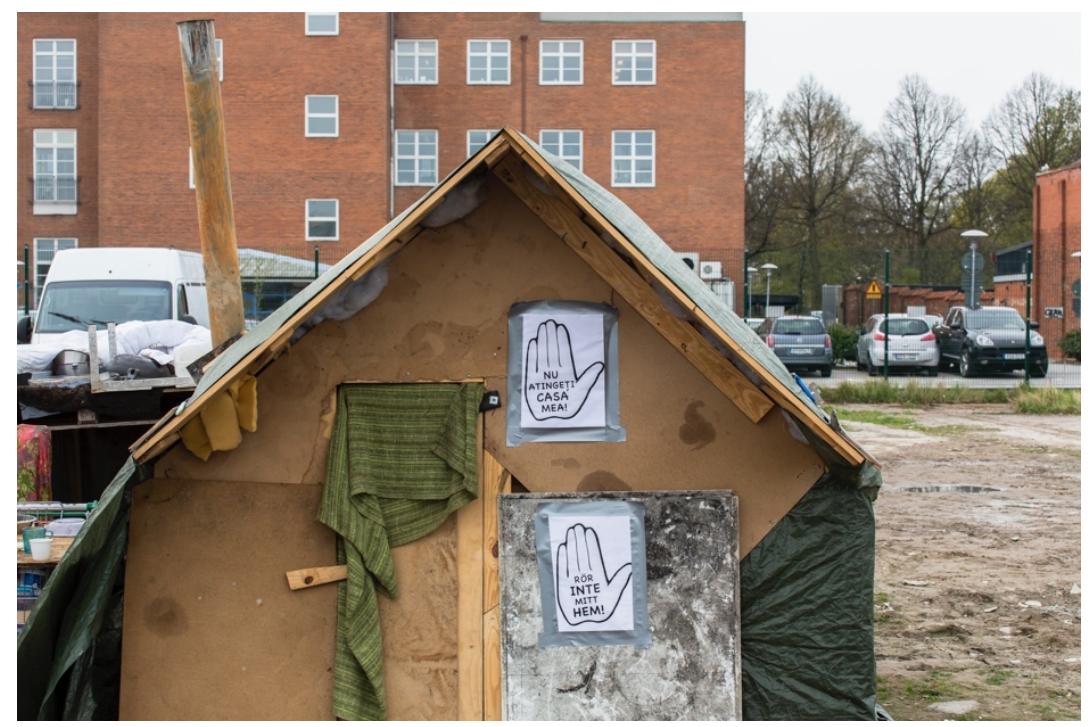

Figure 8. Nu atingeti casa mea! (C) Jenny Eliasson / Malmo Museums

The County Administrative Board (CAB) eventually ruled in favour of the squatters and revoked the prohibition order on procedural grounds. 
Notably, the court based their decision on the same basic principle that had proved a stumbling block in the context of the civil law eviction procedure. In short, the court argued that the order was invalid - that is, inconsistent with the rule of law - because it had been addressed to a 'circle of unnamed persons' ${ }^{67}$ Once again then, the relative anonymity (and consequent illegibility) of the squatters made them difficult to take legal action against.

Determined to move forward with the case, the Environmental Administration appealed court's decision in the second instance, the Land and Environment Court. However, the court reaffirmed the interpretation of the County Administrative Board (Mark och miljödomstolen i Växjö, M 2516-15). ${ }^{68}$

The remainder of the spring and summer passed while the authorities seemed to be biding their time. The City of Malmö Director of Safety would later explain that there had been tentative plans to move ahead and remove the settlement already in the spring, but the authorities waited so that the city administration would have time to develop a policy and plan for how act in the aftermath of a possible eviction and what they should do if the squatters from the Sorgenfri camp relocated and set up new encampments elsewhere in the city.

In early October, 2015, the local newspaper Sydsvenskan reported that the police were gearing up for a major operation, having enlisted several hundred officers from around the country to assist in an intervention concerning the Sorgenfri camp.

\footnotetext{
${ }^{67}$ As it is stated in the ruling, 'Eftersom det är okänt vilka personer som vid tillfället för förbudets utfärdande befann sig på fastigheten och ett förbud av aktuellt slag inte kan göras gällande mot annan än den eller de som har förelagts, saknas det förutsättningar att verkställa förbudet'.

${ }^{68}$ The Environmental Administration appealed to the highest-instance court, the Land and Environment Appeal Court. However, the appeal was withdrawn after the Sorgenfri camp had been demolished.
} 


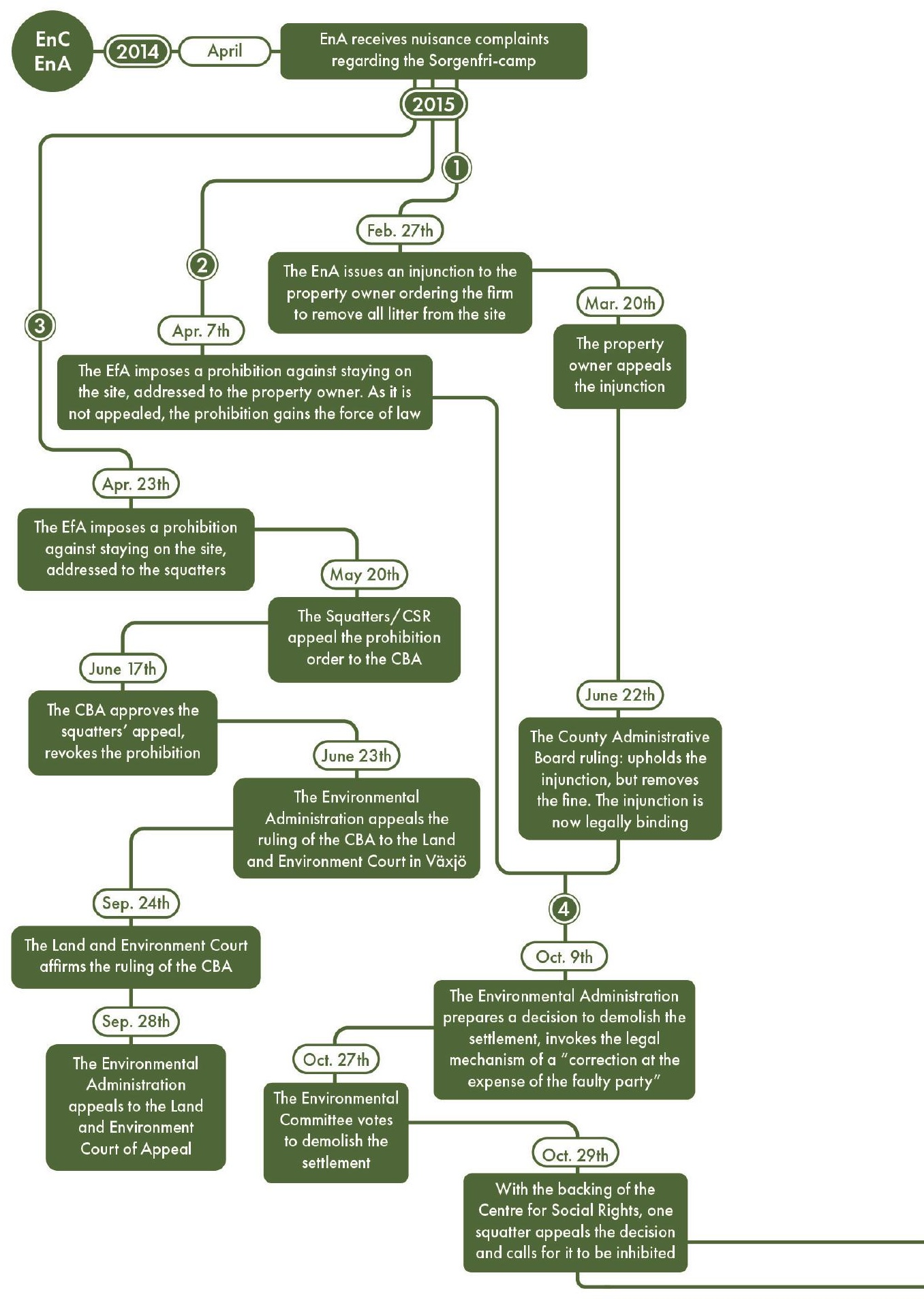




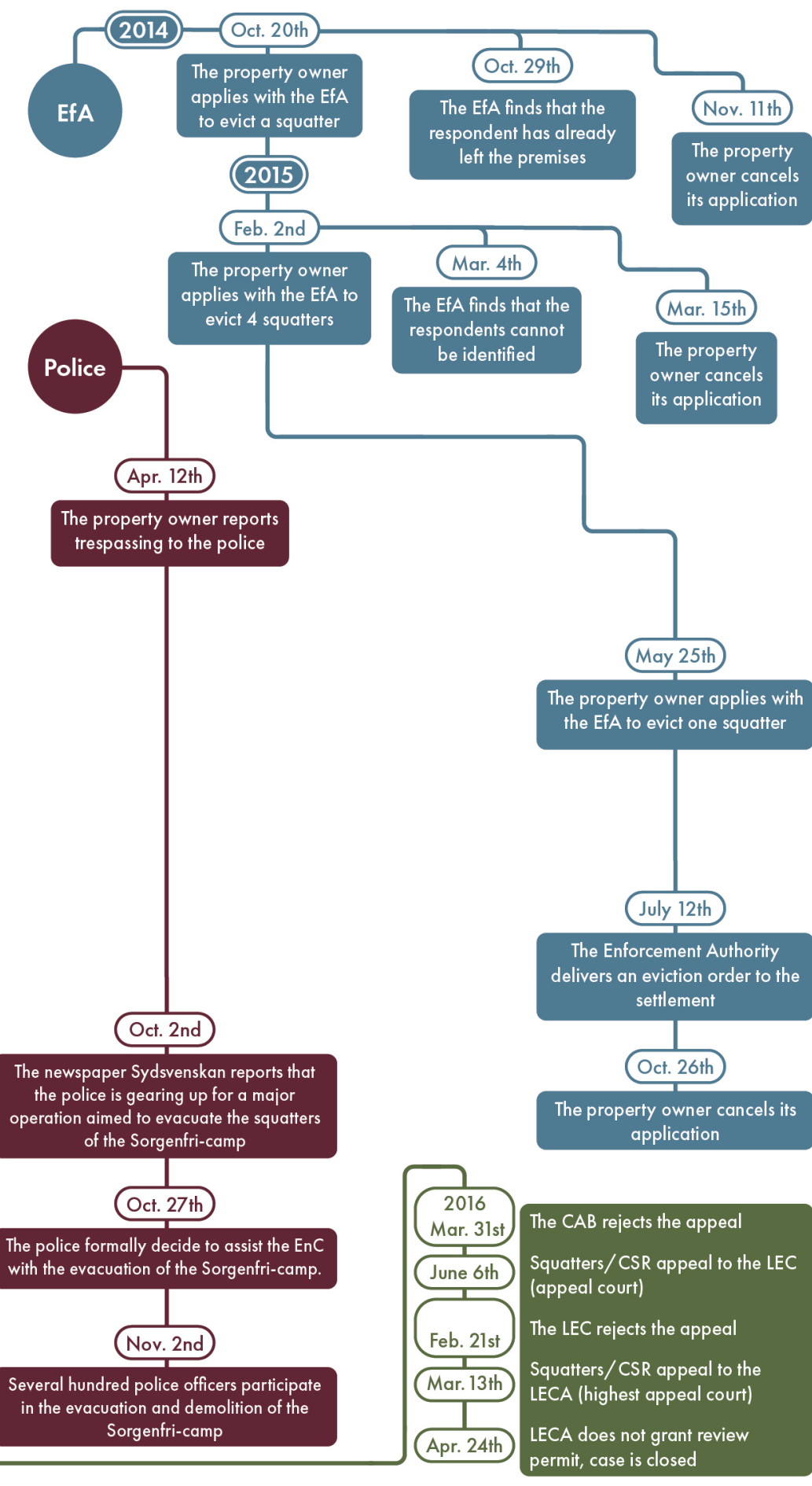


A couple of weeks later, on October 27, 2015, the Environmental Committee voted in favour of a proposal to evacuate and demolish the settlement. The decision relied on a mechanism of the Environmental Code called 'a correction at the expense of the faulty party' (Sw: Rättelse på den felandes bekostnad, $26 \mathrm{Ch} .18 \S, 1998: 808$, hereafter referred to as a 'correction'). This mechanism extends the powers of the public authorities to correct a legal wrong (e.g., a nuisance) in cases where the liable party does not comply with a previously issued injunction or prohibition order or if the authorities finds that a correction needs to be carried out immediately in order to prevent serious injury. ${ }^{69}$ In this case, the Environmental Committee re-activated the two previous decisions the injunction that required the property owner to remove all litter from the site along with the first prohibition order (dated 2015-04-07) that had been issued to the property owner.

While previous attempts to remove the squatters from the site had failed because of the due process requirements to identify and address them directly as legal subjects, this mechanism (i.e., the correction) allowed the Environmental Administration to circumvent these requirements altogether. It did so by treating the property owner - rather than the squatters - as the respondent to the correction order and by emphasising the need for urgent intervention. Indeed, the decision of the Environmental Committee specified that due to the urgency of the situation, it was of outmost importance to take immediate action to address the environmental and health situation in and around the settlement; the decision would therefore be effective immediately - even if it was appealed. ${ }^{70}$ The effect was to re-categorise the settlement to a

\footnotetext{
${ }^{69}$ This is how it is worded in the EnC: $18 \S \quad$ I stället för att begära verkställighet enligt $17 \S$ får tillsynsmyndigheten besluta att rättelse skall vidtas på den felandes bekostnad. Beslut om rättelse på den felandes bekostnad får meddelas utan föregående föreläggande eller förbud, om tillsynsmyndigheten med hänsyn till risken för allvarliga skador finner att rättelse bör göras genast eller det finns andra särskilda skäl.

${ }^{70}$ With the support of the Centre for Social Rights, some of the squatters did appeal the decision and requested that the demolition should be inhbited. Their argument was that the demolition would violate the squatters' human and minority rights. (The European Court of Human Rights has previously declared evictions of Roma communities to be in violation of human and minority rights norms). However, the Country Administrative
} 
mere nuisance and to reduce the squatters to the status of bodies that needed to be moved in order to execute the correction order. As such, the decision functioned to deflect any claims the squatters might have had to the site; it denied them legal standing and left them with few opportunities to seek legal recourse. Here, the use of the mechanism of correction can be usefully understood as a spatial tactic, by which I mean the 'use of space as a strategy and/or technique of power and social control' (Low \& Lawrence-Zúniga, 2003, p. 30; see also Sylvestre et al., 2015; Zick, 2006).

\section{Addressing Illegibility}

Having accounted for the entangled administrative and legal processes that eventually resulted in the evacuation and demolition of the Sorgenfri camp, I want to now provide a further analysis of these processes in terms of their dynamics and legal effects.

As I have explained, both the property-owner and the Environmental Administration were unable - rather, they found it practically complicated - to take legal action directly against the squatters. In the context of the civil-law eviction procedure, the property owner was faced with a requirement to provide the Enforcement Authority with the names and personal information of the squatters in order to have them evicted. Similarly, the Environmental Administration was prevented by the court from addressing the prohibition order to the collective 'circle of persons' staying on the site. What was at stake in both cases was a core principle of legal certainty according to which those who are subjected to an eviction or prohibition order should be addressed directly and individually - not least so that they could have an opportunity to dispute the order.

What made it so complicated for the property owner and the authorities to abide by these requirements was that the squatters were not registered

Board rejected their request for the demolition (interim decision) to be inhibited, and later they determined that the evacuation did not violate human and minority rights norms/legal precedents. 
on the site (nor as residents of the city) and that there was a constant turnover of people on the site. The case of the Sorgenfri camp thus lends support to Sigona's (2014) observation that camps offer a measure of anonymity to their residents, allowing them to 'disappear in the mass'. ${ }^{15}$ However, this anonymity can be a double-edged sword: The paradox of camp places (more specifically, Roma camps) is that they make individuals invisible, yet they also project an image of their inhabitants as an undifferentiated collective into the public imagination (p. 9).

Indeed, with each failed eviction attempt, the Sorgenfri camp garnered more and more attention, and over time, it became quite literally the central locus of the state legitimacy crisis that Hansson and Mitchell (2018) refer to as the 'settlement crisis' (p. 26). Across the country, especially in the major cities, the property owners association, Fastighetsägarna, were voicing loud concerns that it was practically and legally difficult to evict the unauthorised encampments of "vulnerable EU citizens' (Köning Jerlmyr, 2015; Öhrström, 2016). While the red-green coalition government vacillated on how to best address the situation, the right-wing parties launched a number of proposals to simplify the eviction procedure and increase the powers of the municipalities to remove unauthorised settlements, thus putting pressure on the government to do something about the situation (cf. Barker, 2017; Hansson \& Mitchell, 2018). Leaving aside the more overtly ideological dimensions of this socalled settlement crisis, I want to suggest that the basic technical-legal issue at stake can be usefully understood as a problem of illegibility: the relative anonymity of the squatters made them not-readable in the eyes of the authorities, which made them difficult to regulate.

In his well-known treatise Seeing Like a State, the political anthropologist James C. Scott (1998) makes the case that 'legibility' is a fundamental and enduring issue in statecraft: To be able to govern efficiently, the state needs to arrange its people as well as its terrain in ways that facilitate functions like taxation and law enforcement (p. 2). One of Scott's key arguments is that the modern state (and modernist rule, more generally) is defined by its unique capacity to render both its subjects and its territory legible (i.e., visible and readable) to the state administration. This 
capacity, is thus an historically conditional achievement that relies on the imposition and continuous maintenance of standardised schemes of identification and classification, such as cadastral maps, population registries, and systems of permanent family surnames. While the premodern state was 'in many crucial respects, partially blind' (p. 2), the modern state developed and continues to develop a synoptic bird's-eye view of the population and the territory it governs. ${ }^{71}$ For Scott, this view is a salient feature of modernist rule, and it distorts and simplifies the rich complexity of locally-based social practices and knowledges.

There is much to be said for Scott's analysis. However, it fails to appreciate that this strong reliance on schemes of legibility also means that the modern state has difficulties making sense of and managing people and phenomena that do not fit neatly within its standardised administrative grids. Such people and phenomena seem to have a capacity to short-circuit the schemes of legibility. The Sorgenfri camp case and the overall 'settlement crisis' is an example of this. While Scott does acknowledge that the simplification necessary to create and maintain schemes of legibility is never fully complete, his account of modernist rule tells us little about how the state might govern (or attempt to govern) when the schemes of legibility run up against their own inherent shortcomings, failures, and contradictions. This is where the work of Blomley (2007b, 2011, 2012), Ghertner (2010, 2015), and Valverde $(2010,2011)$ is instructive: It explains how state authorities attempt to resolve problems of illegibility by reverting to forms of rule that are more discretionary, flexible, and subjective - with nuisance governance being a key example of such forms of rule. Related to this, scholars of informality have observed that much urban planning and management occurs through a form of 'caluculated informality' (Roy, 2009, p. 83), where the law is both 1) left ambigious and open to discretionary

\footnotetext{
${ }^{71}$ Notably, Scott (1998) states that he came across the idea of 'il/legibility' while researching the efforts of states to 'sedentarise' itinierant populations including so-called nomads and 'gypsies'. He explains, 'The more I examined these efforts at sedentarisation, the more I came to see them as a state's attempt to make a society legible, to arrange the population in ways that simplified the classic state functions of taxation, conscription, and prevention of rebellion' (p. 2).
} 
interpretation and 2) enforced inconsistently and unevenly so that certain transgressions are tolerated while others are not (Clough Marinaro, 2014a, 2017; Roy, 2004, 2005, 2009; Yiftachel, 2009b, 2009a). Seen from this perspective, the use of informality and of discretionary power appears itself as a mode of governance - one that can be strategically employed to advance particular interests. As I will argue, this is precisely what the Swedish authorities have done to attempt to resolve the settlement crisis: In the face of a problem of informality and illegibility, the authorities have resorted to instruments that are themselves discretionary, informal, and even extra-legal. Indeed, if we go beyond the Sorgenfri camp case and look at the bigger picture of the national socalled settlement crisis, it becomes clear that the various arms of the state responded to this crisis and to the basic problem of illegibility in three main ways: 1) by re-writing the rules, 2) by circumventing or altogether ignoring the rules, and 3) by shifting from one set of rules to another. In what follows, I discuss these three approaches in more detail before I move on to consider the effects of the shift from the register of civil-law to environmental law.

Re-writing the rules. As a response to the so-called settlement crisis, the government announced that they would initiate a review and revision of relevant laws with the stated intention of 'improving the possibilities' for 'removing' unauthorised settlements (see DS 2016:17). This review eventually resulted in an amendment to the Enforcement Code (SFS 2017:467): A new mechanism called 'removal' (Sw: avlägsnande) was added, which came into force in July 2017. The mechanism allows private property owners to apply to the Enforcement Authority to have a group of people removed from their property without having to provide the agency with the names of each individual member of the group if 'despite reasonable efforts they can not obtain this information'. The previous due process protections have been replaced with an alternative set of requirements: Instead of inviting each individual evictee to dispute their eviction, the new procedure requires the Enforcement Authority to give the unnamed respondents a window of time to appeal an eviction order before it is enforced. It also makes it incumbent on the Enforcement 
Authority to carry out a proportionality assessments before deciding on an eviction. Human rights advocates have noted that this opens a small but still significant window for squatters to contest eviction orders on humanitarian grounds (e.g., Hammarberg, 2019). Nevertheless, the most immediate impact of the amendement is to increase the discretionart powers of the Enforcement Authroity.

Circumventing or disregarding the rules. A review of the Enforcement Authority's own records (i.e., before any amendments had been made to the relevant laws) confirms that the agency carried out a total of 81 evictions of unauthorised camps (directly affecting a total of 992 persons) in the year 2015 (Kronofogden, 2015). Significantly, the prevalence of evictions was highly uneven across the country. This suggests that the agency's various regional branches interpreted and enforced the relevant due process protections inconsistently and unevenly. As one journalist explains, 'the removal of migrant camps [was] a lottery' (Holm, 2015). The same requirement that proved to be such a major stumbling block for both the private property owner and the municipal authorities in Malmö was effectively circumvented or disregarded in a number of other similar cases elsewhere in the country. In some cases, the Enforcement Authority got around the requirements by addressing the eviction order to an intermediary respondent. For example, in Umeå, in the north of Sweden, the Enforcement Authority was able to remove a group of EU citizens camping on a piece of land that was being rented by the Swedish Church by citing the church as an intermediary respondent (Strömberg, 2015). However, in other cases, it appears that the agency disregarded the due process protections altogether (Civil Rights Defenders, 2017)

The fact that some found ways to circumvent or simply disregard the due process protections is a strong indication that the officials of the Enforcement Authority were able to exercise a degree of discretion - and that they did so at the expense of squatters' legal certainty and security. Moreover, it suggests that officials in Malmö interpreted and enacted the due process protections more rigorously than their counterparts in other areas of the country. The sheer size and visibility of the Sorgenfri camp seems to have played a role in this context: It made it impossible to hide 
from view the more legally dubious aspects of the authorities' attempts to have squatters removed. Having followed the case closely, I am also convinced that the anti-eviction activism and organising that took place in and around the Sorgenfri camp made a difference, both directly and indirectly. Directly in the sense that the Centre for Social Rights appealed the various eviction orders on behalf of the squatters, thus forcing the authorities to formally legitimise and justify their actions. Indirectly in the sense that the various activist groups and human rights organisations that got involved with the case acted as watchdogs on the municipal and state authorities, forcing them to act accountably.

Shifting from one set of rules to another. Of course, in the end, the Sorgenfri camp was still evacuated and demolished. The environmental law mechanism of 'correction' provided a means to get around the due process requirements and the problem of illegibility - but without directly disregarding the rules. Rather, the authorities resolved their dilemma by shifting from the civil law eviction procedure into a different register altogether. Crucially, this shift involved a re-making of the object of intervention. Here, I would like to recall Santos' (1987) observation that 'different forms of law create different legal objects upon eventually the same social objects' (p. 287). The shift from the civil-law eviction procedure to the environmental law procedure involved a recategorisation of the settlement from an unauthorised occupation into a virtual garbage heap and a major nuisance to health. Significantly, this also changed the legal status of the squatters. In the context of the civil law eviction procedure, they were legal subjects (specifically 'respondents') with abilities to leverage due process protections. The specific procedure that the Environmental Administration devised, however, effectively stripped them of this status. In a sense, they became legally reduced to litter.

The case of the Sorgenfri camp is an idiosyncratic one. While nuisance and sanitation hazards are frequently cited as grounds for eviction, the Sorgenfri camp remains, to this date, the only settlement of 'vulnerable EU citizens' to have been demolished directly on the basis of environmental law (cf. Davis \& Ryan, 2016). Despite its singularity, it is 
illustrative of a more widespread tendency to shift registers and to mobilise discretionary and flexible forms of law. The National Coordinator's recommended zero-tolerance approach towards unauthorised settlements is a case it point. It relies not only on the rewriting of the existing eviction laws but also, crucially, on a shift from property law to public order and police law. In fact, Valfridsson gave an interview in connection with the demolition of the Sorgenfri camp where he explicitly called for the police to 'take a step forward' and mobilise The Public Order Act (Sw: Ordlingslagen) or The Police Act (Sw: Polislagen) to avert trespassing crimes and pre-empt the establishment of another large and difficult-to-evict settlement (cited Saarinen, 2015). In chapter seven, I will discuss the on-the-ground reality of the zerotolerance approach. Here, it suffices to note that if the shift from property law to environmental law in the case of the Sorgenfri camp case effected the re-categorisation of the settlement into a mere nuisance, this strategic shift into the register of public order and police law relied (and continues to rely) on treating street-homeless 'vulnerable EU citizes' primarily as an order issue.

\section{Features and Effects of Nuisance Government}

To understand the consequences of the use of nuisance law in the case of the Sorgenfri camp, it is useful to attend to the features of the law itself. For Valverde (2011) nuisance law serves as the paradigmatic example of 'premodern ways of seeing and managing urban disorder' and is closely wedded to a police rationality of government (p. 280). Based on an extensive genealogy of U.S. urban law, she argues that although nuisance regulations have successively been supplemented with a host of modernist 'seeing like a state'-type legal technologies (the primary example being the mechanism of zoning), these technologies have never fully replaced the older, pre-modern ways of seeing. Rather, nuisancetype regulations which govern unquantifiable offensiveness in an intersubjective, relational, and localised manner are often revived when the objective standards characteristic of modernist approaches to urban governance run up against their own inherent failures and contradictions, such as when they encounter a problem of illegibility (see also Ghertner, 
2010,2015). Again, I would suggest that this is what happened in the case of the Sorgenfri camp. To more fully understand the significance of this shift (from one legal register to another) requires an engagement with the category of nuisance itself.

As we saw in the previous chapter, nuisance ( $\mathrm{Sw}$ : olägenhet) is a term that is widely used within both public and policy discourse to identify various disturbances, inconveniences, and irritants. However, as an element of environmental law, it has a specific history and meaning. Nuisance regulations govern diverse objects ranging from garbage and littering, indoor climate, noise, noxious smells, and smoke emissions but they always do so by regulating the use of property. The concept of nuisance that is found in the current Swedish Environmental Code (EnC, SFS 1998:808) can be traced back to the pre-modern neighbour relations law (Sw: grannrätten) (Michanek \& Zetterberg, 2017). In its current formulation, it derives most directly from the public health and sanitation regulations of the early industrial era. It is given a specific definition in the context of health protection ( $\mathrm{Sw}$ : hälsoskydd): 'a nuisance to human health is a disturbance that according to a medical or hygienic evaluation may have a detrimental effect on health, which is not minor or entirely temporary' (9 Ch $3 \S$ SFS 1998:808). ${ }^{72}$ This definition is a re-working of the concept of 'sanitary nuisance' that was introduced into Swedish law with the 1919 Health Care Statute (Bro, 2000). It resembles what in the common law tradition is called a public nuisance, namely an activity that not just interferes with someone's use and enjoyment of their land but also causes significant injury or threat of injury to the public at large (Cooper,

\footnotetext{
${ }^{72}$ The current Swedish Environmental Code (EnC, 1998:808) constitutes the primary regulatory system for environmental protection and preservation in Sweden today. It was adopted in 1999, consolidating 16 previously existing environmental laws, including the Environment Protection Act (1969:387), the Health Protection Act (1982:1080), the Public Sanitation Act (1979:696), and the Nature Conservation Act (1964:822). The Environmental Code is a framework law (Sw: ramlag), and its overall aim, as defined in the opening section of the code Ch. $11 \S(1998: 808)$, is to promote sustainable development in order to ensure a 'good and healthy environment' for present and future generations. Thus, one of its core objectives is to offer protection against 'injuries' (Sw: skador) and 'nuisances' (Sw: olägenheter) that negatively impact the environment and human well-being [Nilsson, 2010]. As a composite law, the EnC governs a wide range of issues and integrates elements of public as well as private law, which reflects its complex legal history.
} 
2002 , p. 8) ${ }^{73}$ The contemporary concept of 'nuisance to human health' also shares a history with common law public nuisance regulations. Both developed in tandem with the emergence of the industrial city as a response to the spread of derelict and often over-crowded living conditions among the poor- and working classes (for a more comprehensive analysis of the history of Swedish health care protection law, see Bro, 2000).

Overall, nuisance is a flexible and open-ended category. This is evident in the way that nuisance regulations have been invoked and continue to be invoked to a variety of different ends, ranging from environmental activism to the regulation of so-called anti-social behaviour (Cooper, 2002; Valverde, 2011, p. 292). Given the shifting content and application of nuisance law, it is best understood as a particular form of governance:

The content of nuisance is by definition indeterminate, since nuisances emerge only in relation to certain contexts and remain specific both to a certain kind of place and to a certain social community. ... The form, by contrast, is what gives nuisance governance the minimal determinacy it has. (Valverde, 2011, p. 296).

According to Valverde (2011), nuisance governance can be defined on the basis of three enduring 'features of form'. First, nuisance regulations are generally backward-looking. While regulatory mechanisms such as licenses and permits are forward-looking (i.e., predictive and preventive), nuisance abatement measures are mostly reactive. Second, 'nuisance' as a legal concept and category is inherently subjective. Nothing is a nuisance by its intrinsic qualities, rather 'a nuisance is something that bothers someone' (p. 297). Third, nuisance regulations have certain spatialising effects: Nuisances tend to be locally-specific, and the task of nuisance abatement is always restricted to a particular area, building, or property. Thus, in the words of Valverde (2011), nuisance regulations tend

\footnotetext{
${ }^{73}$ In the common law tradition, there are two main categories of nuisances: private and public. The former is an element of tort law, and it is typically defined as an activity that can be deemed to constitute an interference with someone's use and enjoyment of their land (Cooper, 2002, p. 8). The latter is generally defined as an activity that not only interferes with the rights of an individual property owner but also causes injury or threat of injury to the public at large.
} 
to '[localise] both problems and solutions' (p. 296). While the first feature is rather self-explanatory, I would like to address the second and third one in some more detail. These are also the features that are most directly relevant to the case of the Sorgenfri camp.

The inherent subjectivity of nuisance governance is immediately apparent in the case of the private nuisance complaints discussed in the previous chapter. Again, what gets defined as a nuisance is that which bothers someone enough for them to pick up their phone or computer and file a complaint. ${ }^{74}$ To some extent, this is probably determined by the complainants' individual sensibilities; however, as Davina Cooper (2002) emphasises, nuisance is also a social category in the sense that such sensibilities are dependent on socially constructed, historically and geographically specific norms of order and propriety. Indeed, if nuisance regulations are enacted to uphold standards of cleanliness and order, it is necessary to recognise the social meanings that underpin such standards. Here, we might recall Mary Douglas's (1966/2002) argument that dirt is a relative idea and that it always relies on an underlying, often unsaid and unquestioned, symbolic order. As both Cooper (2002) and Ghertner (2012) suggest, there is often an explicit or implicit class- and racialised politics to nuisance governance. Indeed, for Ghertner (2012), one of the primary functions of what he calls 'nuisance talk' (i.e., everyday middle class that identify slums as dirty and degenerate) is to establish a 'shared aesthetic disposition' among middle-class residents, which consequently serves to reinforce certain bourgeois norms of civility and propriety. In the Swedish context, such norms have historically been inflected by the discourses of social hygiene and conditioned by the state's attempts to create a respectable and orderly people (Bro, 2000; Broberg \& Tydén, 1991; Hirdman, 1989). Further, as we saw in the previous chapter, cleanliness and orderliness continue to be seen as specifically Swedish virtues.

\footnotetext{
${ }^{74}$ The Environmental Administration in Malmö recognises this as a problem, and since a few years back, they carry out pre-emptive nuisance inspections in areas of the city (especially low-income areas) where residents are less likely to report concerns.
} 
As for the spatialising effects, nuisance governance treats the symptoms rather than the causes of environmental and health problems. Refracted through nuisance law, complex social phenomena like the Sorgenfri camp are reduced to their basic material, sensory and spatial elements: noxious smells, smoke emissions, an ever-growing mound of garbage, overflowing porta-potties, open fires, or a leaky tent. This tendency of nuisance law to localise both problems and solutions is linked directly to the fact that it regulates property. As Valverde (2011) notes, nuisance abatement always involves 'specific and usually local solutions: Put in a retaining wall here, install filters in this factory chimney, move your noisy bar to a high-density district' (p. 296). Or, as is common in the context of slum-removal, demolish this specific settlement (cf. Ghertner, 2015). Accordingly, the protections offered by nuisance law are not codified in law as belonging to persons. As Valverde (2011) explains it, "the "quiet enjoyment" of one's property that is the guiding star of nuisance and quasi-nuisance law is not a right that persons have ... but rather a privilege that flows from one's links to property' (p. 295).

This is poignantly evident in the case of the Sorgenfri camp. The decision of the Environmental Committee was to abate a nuisance, but only on the particular site of the settlement and without any guarantees being offered that the squatters would not be exposed to worse nuisances once they had been evacuated from the site. The decision took the form of a prohibition against living in substandard conditions, rather than a positive intervention to, say, assure the right to adequate shelter. In the case of the Sorgenfri camp, the exclusionary nature of the decision was compounded by the fact that the evacuees had no (or a highly temporary and uncertain) right of residence and therefore only minimal access to social services and shelter. However, the basic problem is not unique to the case of the Sorgenfri camp, it also affects other housing insecure groups. For example, if you live in a rental apartment that is deemed by the authorities to not be suitable for habitation and your landlord is prohibited from 
continuing to rent it out, you can be made to move out, but you have no right per se to be re-housed..$^{75}$

Clearly then, nuisance law is not a rights-based law. As a paradigmatic example of 'urban-' or 'municipal law', it operates in an altogether different register than, for example, criminal- and humanrights law, which are both 'laws of persons'. Valverde (2005) notes,

Municipal law certainly governs persons, and even specific groups of persons, and not only dispossessed or marginal groups: but it does so in a different manner than criminal law or constitutional rights law. Local authorities govern persons as well as pieces of land and buildings, but they generally avoid governing through the category of 'person' that is so central to liberal governance and hence to law. ( $\mathrm{p}$. 37)

Because nuisance law operates through categories of property and space rather than categories of persons, it tends to effectively block or deflect rights-based arguments. The legal geography literature on spatial tactics and regulations offer several different examples of this. For example, Hubbard (2013) shows how nationally-secured rights to sexual expression for LGBTQ individuals are eroded through local-level public order policing targeting displays of homosexual intimacy (see also Crofts, Hubbard, \& Prior, 2013; Prior, Boydell, \& Hubbard, 2012). Similarly, Blomley's work $(2007 \mathrm{a}, 2010,2011)$ on the regulation of panhandling through the enactment of traffic regulations elaborates on the ways in which such regulations deflect right-based arguments, and why this makes them resistant to constitutional challenge. Blomley's analysis speaks directly to the present case. As the title of one of his articles 'How to Turn a Beggar into a Bus Stop' - captures, the use of traffic law to address sidewalk begging works to translate the social object of 'the beggar' into a legal object not much different from a telephone pole or a bus stop: an element which interrupts the smooth flow of sidewalk movements (Blomley, 2007b). Based on a review of case law on the

\footnotetext{
${ }^{75}$ As an environmental lawyer pointed out to me, this spatiality of environmental law (i.e., the restricted geographical reach and localising effect of many environmental regulations, not just nuisance regulations) is a major impediment to effective regulation of a range of environmental issues that do not confine themselves to specific, discrete parcels of land.
} 
constitutionality of anti-begging measures, Blomley (2007b) notes that civil rights organisations often attempt to challenge such measures by arguing that they violate the rights of persons and/or discriminate against particular groups of people. However, such attempts are likely to fail when the measures in question do not regulate through categories of persons. In Blomley's own words,

Rights-based arguments around begging law, which time and again insist that identified persons are treated inequitably are negated, again and again, by the counter-argument that law is not regulatory of persons, but rather of actions and spaces. The purpose of the law, the courts say, is not to discriminate against people who panhandle, but rather to treat panhandling as a spatial activity that must be balanced with other activities, according to the overall function of the place. (2007b, p. 1705)

He continues,

[The technical legal categorisation of beggars as traffic] does some heavy ideological lifting, effectively blocking constitutional arguments on behalf of the public poor. Yet it does so by presenting begging law as not only respectful of equality, but actually constitutive of it. Using an alchemical language of space, use and mutual respect, it alchemically transmutes the intolerances expressed by those who seek such law, and the oppressions of those who suffer under it. (p. 1707)

A similar alchemical language is evident in the Sorgenfri camp case. By legally categorising and treating the physical object of the Sorgenfri camp as a nuisance and sanitation hazard, the authorities were able to legitimise the evacuation and demolition of the settlement in positive terms as a means to care for the well-being of the squatters and the public at large. The evacuation was also justified with reference to an equality-oftreatment argument. As the public officials and politicians who prepared the decision would have it, it would have been discriminatory to not give the squatters the same treatment as anyone else. Altogether, this served to negate rights claims on behalf of the squatters - claims that largely relied on a language of human rights and on arguments of group-differentiated rights to protection. In the following section, I will elaborate on this point. In doing so, I will make an argument about the frustrations and limitations of rights litigation that I believe have relevance beyond the specific and 
somewhat idiosyncratic case of the Sorgenfri camp. Indeed, the tendency of urban law to deflect or negate rights-based claims seems to me a crucuially important factor to consider for those involved in Roma rights advocacy, especially given that - as Pusca (2010) so aptly puts it - 'the Roma problem' across Europe is frequently treated as a 'space problem' (see also Aradau, 2015; Clough Marinaro \& Sigona, 2011; Picker, 2017).

\section{Regulating Space, Deflecting Rights}

Following the adoption of the Universal Declaration of Human Rights (UDHR) and the historic victories of the U.S. civil rights movements, many progressive organisations and projects around the world have turned to rights-based strategies to advance their causes. Some speak of this shift as an ongoing 'rights revolution' (e.g., Ignatieff, 2000). The international movement for Roma and Traveller rights is very much a case in point: Over the last three or so decades, the anti-discrimination and minority rights paradigm has emerged as one of the dominant frameworks for Roma emancipation (Bunescu, 2014; McGarry, 2010; Sigona \& Trehan, 2009; Vermeersch, 2006). ${ }^{76}$

Broadly speaking, rights can be a powerful tool to affirm marginalised identities and interests. At the same time, they are fraught with tensions and shortcomings, and the effectiveness and empowering potentiality of rights is subject to much debate and scepticism, especially in leftist circles and among critical legal scholars (see Brown \& Halley, 2002). Here, I would like to focus on the basic tendency of spatial tactics and regulations to deflect rights-based arguments on behalf of disenfranchised and impoverished Roma communities. However, the discourse of rights associated with the 'rights revolution' at large has been criticised for being anti-political or depoliticising (Brännström, 2017; Brown, 2004). Scholars on the left also often assert that rights-based approaches to social justice activism are divisionary and counter-productive insofar as they reinforce the individualism of liberal thought and jurisprudence - and

\footnotetext{
${ }^{76}$ Another dominant framework is, of course, that of integration. For an analysis of the relationship between the two, see the work of Morag Goodwin and Roosmarijn Buijs (2013).
} 
because they frequently fail to address injustices rooted in maldistribution (see review in Blomley, 1994, pp. 408-412; Blomley \& Pratt, 2001). For example, the human rights paradigm has been widely critised for neglecting the demands of substantive economic and social justice (see Brown, 2004; Moyn, 2018). The critical Romani studies scholar Peter Vemereesch (2006) makes this same argument in the context of European Roma rights advocacy, arguing that rights-based approaches are insufficient to adequately address issues of poverty and inequality. As concerns minority rights, scholars have further noted that they frequently require the establishment of some definitive criteria for determining who qualifies as a member of a given minority. For this reason, minority rights discourse risks contributing to the reification of minority identities (Brown, 1993, 2000; for an analysis of Roma minority rights discourse, see Farget, 2012; McGarry, 2010).

That said, an appeal of rights is that they impose obligations upon others, especially the state. Indeed, rights claims rely on the translation of various considerations and interests into the language and status of the irrefutable - a moral imperative above and outside of politics. Thus, Dworkin (1977) speaks of rights as 'trumps' that may be played in the last resort to protect certain fundamental freedoms of otherwise powerless individuals or groups. Dworkin's argument is a compelling and distinctily liberal defence of civil disobedience. He argues that when laws infringe upon our fundamental moral rights, the language of rights allows us to challenge such laws, as well as to disobey them. This is also how the squatters of the Sorgenfri camp along with their allies and advocates attempted to mobilise rights claims. The Centre for Social Rights appealed the decision of the Environmental Council on behalf of the squatters, submitting that it was disproportionate and inconsistent with human- and minority rights norms (Centrum för Sociala Rättigheter, 2015). The appeal turned on the argument that the decision to evacuate the squatters was in violation of Article 8 of the European Convention on Human Rights (ECHR) on the right to respect for home, family, and private life, and that the Environmental Council had failed to undertake an adequate proportionality assessment. It also called into question the repressive 
nature of the intervention, asking why the City of Malmö had not undertaken any positive measures to avert the nuisance problems. Meanwhile, several international organisations - including the UN Special Rapporteur for Minority Rights Rita Izsák, the Council of Europe $(\mathrm{CoE})$, and the Stockholm-based international NGO Civil Rights Defenders (CRD) - issued cautionary statements, calling on the authorities to inhibit the evacuation until they could guarantee the resettlement of the squatters.

The strategic turn to the language of rights can be understood as a counteractive game of scale (Valverde, 2009a, 2010) - an attempt to rescale the conflict, strategically shifting it from the jurisdiction of the domestic Environmental and Land Court to the register European humanand minority rights law. In this context, the Swedish legal tradition differs in certain key respects from that of, say, the United States. In the Swedish tradition, rights are not derived directly from the constitution - there is no definitive bill of rights. Furthermore, such rights as the right to housing are typically envisoned not as rights belonging to individuals per se but as collective, social rights that arise from the social contract between state and citizen (Bengtsson, 2001). Sweden also does not have a strong tradition of judicial review (Åhman, 2015) or of judicial activism and strategic rights litigation (Brännström, 2009, 2017). This is generally seen to be changing with the intergration of EU law into national law, and with the growing influence of the European Courts of Justice and Human Rights (Husa, 2010). The rise of right-based social justice activism and strategic litigation is arguably also contributing to what some have referred to as the 'juridification of politics' (see discussion in Brännström, 2017). While the case of the Sorgenfri camp never made it to the European Court of Human Rights (ECtHR), the various human rights organisation who intervened in the case drew extensively on the jurisprudence of the court. In particular, they invoked a series of rulings which jointly establish a precedent of group-differentiated protections for Roma and Travellers. To understand the significance of this move and how it fits into the broader context of the European Roma rights discourse 
and jurisprudence, a brief review of the recent history of Roma rights litigation is in order.

I mentioned already that the minority rights paradigm has come to be one of the dominant frameworks for Roma emancipation. Over the last several decades, following the collapse of Soviet communism and the ascendence of neoliberalism in the post-socialist Central- and Eastern European States, a pan-European Romani movement has emerged that relies strongly on a language of human and minority rights (Bunescu, 2014; McGarry, 2010; Sigona \& Trehan, 2009; Vermeersch, 2006). Since the 1990 s, a number if new advocacy organisations - such as the European Roma Rights Center (ERRC) and Open Society's Roma Initiative Office - have been established to support Romani communities to access justice and claim civil liberties and minority rights. For example, The ERRC engages in strategic litigation with the aim of addressing discriminatory treatment and improving the rights situation of European Roma. Over the years, the organisation has lodged over 60 cases with the ECtHR. Their work has helped to establish what Sandland (2008) refers to as 'a jurisprudence of difference'. Indeed, a set of rulings, beginning with the 2005 landmark case Moldovan and Others v. Romania, has shifted away from conventional rule-of-law-type analyses towards developing a concept of group-differentiated vulnerability and recognising a positive obligation on the part of states to take differences of culture and ethnicity into account (see also O'Nions, 2007; Peroni \& Timmer, 2013). This marks a break from the earlier case law of the court, which for the most part equated anti-discrimination with equality of treatment. ${ }^{77}$

\footnotetext{
${ }^{77}$ Typically, advocates of minority rights submit that anti-discrimination as equality of treatment rests on a flawed and culturally insensitive analysis. Here, the key argument is that an interpretation of the law which is blind to differences rooted in culture/ethnicity or otherwise, tends to produce adverse and decidedly unequal outcomes for minority groups. Thus, as Sandland (2008) puts it, '[i]ndirect discrimination can ensue from failure to recognise difference'.
} 
An important ruling in this context is the 2012 decision in Yordanova and Others $v$. Bulgaria. The case concerned a planned mass eviction of a group of Roma inhabitants from a longstanding settlement built on municipally owned land in Batalova Vodenitsa, a stigmatised neighbourhood in Sofia, Bulgaria. The group had lived on the site for decades but were threatened with eviction following complaints by neighbours about their supposedly unruly and unsanitary behaviour. Here, the Court found that an enforcement of the eviction order would amount to a violation of the applicants' right to respect for home, family, and private life (Article $8 \mathrm{ECHR}$ ). The case turned on the fact that the settlement constituted the applicants' de facto home and that there was no suitable and certain alternative accommodation provided for them should they be evicted. Furthermore, the Court held that the Bulgarian state had failed to recognise 'the applicants' situation as an outcast community and one of socially disadvantaged groups' (Yordanova and Others v. Bulgaria, 2012, para. 129), thus establishing a precedent for future eviction cases. In particular, the Court affirmed the right to adequate housing for impoverished and socially disadvantaged groups and stipulated that group-differentiated vulnerability to homelessness should be factored in when assessing the proportionality of an eviction order (for a review of the case, see Remiche, 2012).

The case of Yordanova and Others v. Bulgaria bears some similarities to that of the Sorgenfri camp. Along with a number of other landmark cases from the ECtHR (e.g., Connors v. The United Kingdom; Winterstein and Others v. France; and the aforementioned Moldovan and Others $v$. Romania), it was invoked in the appeal of the Centre for Social Rights against the ultimate demolition order. Many of the human rights organisations who intervened in the case also referred to these rulings. For example, Civil Rights Defenders posted an open letter to the City of Malmö, citing Yordanova to suggest that the municipality had failed to observe their legal obligation under international law to arrange 
alternative accommodation for the evacuees (Civil Rights Defenders, 2015; see also Stauffer, 2015). Nevertheless, the trump card of rights was lost in the shuffle. While the advocacy group claimed that the case fundamentally concerned the rights of the squatters, the City of Malmö insisted that it was not discriminatory and did not violate Roma minority protections because it did not technically concern the group as such but rather the conditions on the site (i.e., it was technically a matter between the municipal authorities and the property owner). They also argued that they had applied the Environmental Code in a facially neutral manner. As they put it, it would have been discriminatory to make an exception for the squatters on account of them being Roma: by evacuating them, they were in fact upholding the rule of law and the principle of equal treatment. The following is a quote from the letter that the City of Malmö sent as a response to the criticism levied at them by Civil Rights Defenders:

If the Environmental Administration, without legal basis, should refrain from carrying out an inspection in the case of a violation of the Environmental Code solely because a third-party or they who are directly affected by the inspection belong to a certain group, then the procedure would be in violation of the basic principle of legal equality which is established in the constitution (The Instrument of Government).

If we refrain from carrying out inspections only because they who lived and stayed on the site were socially vulnerable EU citizens who are not being offered alternative accommodation by the state or municipality, we would additionally be discriminating against the affected parties by, contrary to the requirements set out in the Environmental Code, accepting that this group (unlike all others) live under such extremely poor sanitary conditions with all the health risks that this implies for themselves and their surroundings. (Malmö stad Miljöförvaltningen, 2015-11-11)

The Courts followed a similar line of argument and rejected the CSR's appeals in two instances. Rejecting the squatter's claims to groupdifferentiated rights and protections, both the authorities and the courts insisted on a more narrowly defined conception of justice as equal treatment. However, the case did not turn simply on the courts rejection of the human rights arguments or their negation of the 'jurisprudence of difference' adjudicated by the EctHR. Ultimately, and in technical legal 
terms, it came down to the negation of the squatters' standing as persons. The lesson here is that spatial tactics - more specially, the use of laws that govern persons by governing space - will tend to deflect rights-based arguments. This is an important issue to recognise for Roma rights advocacy and litigation, one that deserves further scholarly analysis. While research on European Roma rights jurisprudence have delved into the problems of defining Roma identity, there has not yet been any systematic review of the ways in which state authorities circumvent or deflect rights claims by treating Roma communities as 'space problems' - as nuisances or order issues. Nevertheless, we know from social science research that such discursive elisions and forms of legal alchemy are common across Europe (Aradau, 2015; Pusca, 2010; van Baar, 2017c).

\section{Concluding Remarks}

In this chapter, I have described the entangled processes that resulted in the evacuation and demolition of the Sorgenfri camp. I began by explaining how a due process requirement made it complicated for both the property owner and the environmental authorities to have the squatters removed from the site, even though they had substantial grounds for evicting/evacuating them. The complications stemmed from the fact that the squatters (due to their numbers and lack of documentation) could not easily be identified. I suggested that this could be understood in terms of a problem of illegibility: The settlement provided the squatters with a measure of anonymity and made them not-readable in the eyes of the authorities, which consequently made them difficult for the authorities to regulate. However, this 'problem of illegibility' was ultimately circumvented by the City's Environmental Administration and Committee as they invoked a specific mechanism of the Environmental Code (a 'correction') which effectively undid the squatters' legal standing and prevented them from appealing the decision or otherwise seeking legal recourse. Finally, with reference to Mariana Valverde's work on nuisance regulation, I argued that because such regulations govern through the categories of space and property, they tend to deflect rightsbased arguments. In the last part of the chapter, I attempted to show the implications of this in the case of the Sorgenfri camp. Thus, the case of 
the Sorgenfri camp illustrates the effects and consequences of the rescaling of the governance of 'vulnerable EU citizens' to the local level.

Before I end this chapter, I would like to make a final point about the racialising and exclusionary effects of treatment of the Sorgenfri squatters by the municipal authorities. A common line of argument among those who opposed to demolition of the Sorgenfri camp was that the City of Malmö (or more specifically, the public officials at the Environmental Administration) deliberately and strategically 'used' the framework of the Environmental Code to do away with the settlement. However, it is important to make a distinction between intention and effect. Indeed, arguments about the supposedly illiberal and exclusionary intentions underlying the decision to evacuate the squatters do not go very far. They have been emphatically rejected by representatives of the municipal administrations. For example, the city jurist who oversaw the case, Andrea Hjärne Dalhammar, published an op-ed in which she refuted the argument that the authorities 'used' the law in a discretionary way:

The Environmental Committee and environmental law has not been 'used' by the City of Malmö to 'get rid of' the camp in order to make way for the redevelopment of the area. And to say that we used a 'loophole' in the law is to disregard our competency and our objectivity.

My argument here concerns the effects of the procedure in question rather than the motivations underpinning it. I am not saying that the Environmental Committee acted with the intention of excluding the squatters from the city, nor am I saying that they stepped in to evacuate the squatters on behalf of the real-estate firm. The evacuation and demolition effectively rendered the squatters homeless and restored more or less exclusive rights over the site to the private owner; however, this does not mean that the arguments used to justify the demolition of the settlement were mere smokescreens for an underlying and presumably truer agenda - be it a defence of private property, the redevelopment of the area, or the exclusion of 'vulnerable EU citizens' from the city altogether. 
This is more than a semantic point. It relates to how I approach the relationship between government practice (including various legal practices) and 'deep level' social structures and vested interests (e.g., capitalism and racism). I suggest there may be multiple incongruent and sometimes directly competing rationalities at play in a case like this one, and in government practice more generally. My material suggests that the Environmental Administration had their own reasons for intervening in the case. The regulations they invoked, far from being naked instruments of exclusion and oppression, were (and continue to be) riddled with contradictions. The administrative process that ultimately resulted in the evacuation and demolition of the settlement was a convoluted and contradictory one. Sometimes it worked in the interests of the squatters, other times it did not. In the end, what matters is its effects.

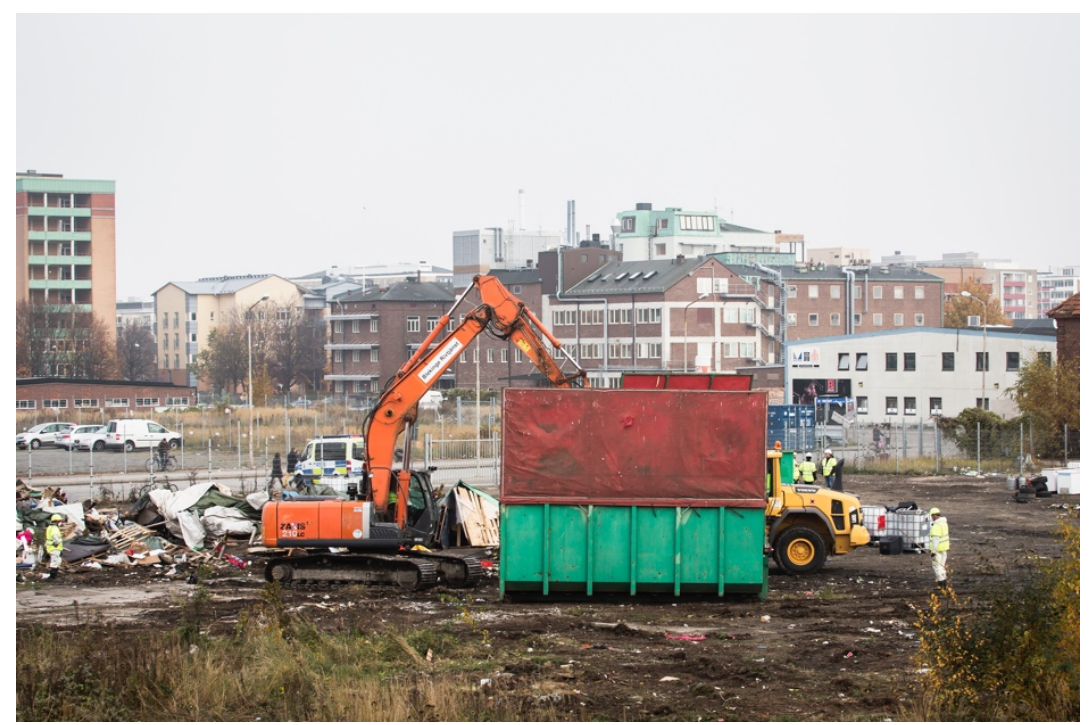

Figure 9. Wrecking crews demolishing the Sorgenfri camp.

(C) Jenny Eliasson / Malmo Museums 


\section{UNDOING THE GEOGRAPHIES OF SURVIVAL}

In the previous two chapters, I introduced the case of the Sorgenfri camp and discussed the social production of the settlement as a nuisance. I also analysed the administrative and judicial process that resulted in the demolition of the settlement and the evacuation of its residents. In this chapter, I broaden my focus, and discuss local policies and practices visà-vis ‘vulnerable EU citizens' in Malmö more broadly.

The chapter has three main parts. In the first part, beginning with the section 'Entry Point: A One-Way Bus Ticket Back to Romania', I discuss the rights of 'vulnerable EU citizens' to access social benefits at the municipal level. This discussion sets a framework for the subsequent part ('Local Initiatives and Policy'), in which I trace the development of local initiatives and policy both prior to and after the evacuation and demolition of the Sorgenfri camp. In particular, I discuss the adoption of a policing strategy to eliminate and prevent the re-emergence of unauthorised settlements. In the third and final part of the chapter ('Undoing the Geographies of Survival'), I address the situation of 'vulnerable EU citizens' in terms of their access to urban space - spaces to rest their heads and attend to other basic needs. 'Geographies of survival' are defined as the 'ad hoc and vulnerable networks, institutions, and practices through which the homeless are able to - against all the odds - sustain themselves in urban spaces' (Klodawsky \& Blomley, 2009, p. 547). I borrow the concept from Mitchell and Heynen (2009), who use it to describe how developments in public space regulations and surveillance affect the living conditions - and indeed, the conditions of possibility for survival of homeless individuals in U.S. cities. They themselves draw inspiration from the legal scholar Jeremy Waldron's seminal work on the relationship between homelessness and freedom, and his famous truisms, that ' $[\mathrm{n}] \mathrm{o}$ 
one is free to perform an action unless there is somewhere [they] are free to perform it' (Waldron, 1991, p. 296). The chapter concludes that the last several years have witnessed a seemingly systematic - although not complete, and always contested - elimination of the geographies of survival for 'vulnerable EU citizens'.

\section{Entry Point: A One-Way Bus Ticket Back to Romania}

As it was announced that the Sorgenfri camp would be demolished, the social service division of the City of Malmö stepped forward to offer two different kinds of emergency support to the soon-to-be evacuees: access to a short-term emergency shelter, and free bus trips to Romania. The shelter would stay open for a total of five nights after the planned evacuation, but it only had room for 50 people. The evacuees numbered at well over 100. In the end, about 60 of them accepted to go on a chartered bus back to their hometowns in southern Romania. ${ }^{78}$ None decided to stay in the shelter (Andreas Persson, 2015).

Although the evacuation and demolition of the Sorgenfri camp was in some ways a singular event, it has been the practice of the City of Malmö Social Services Administration ( $\mathrm{Sw}$ : Sociala resursförvaltningen) since at least 2014 to provide what is sometimes referred to as 'emergency social assistance' (Sw: nödstöd) to homeless and otherwise destitute EU citizens - primarily, if not only, in the form of a return trip ( typically a bus ticket) to the applicant's country of national citizenship (Sociala resursförvaltningen, 2015).$^{79}$ Records show that a total of 80 'vulnerable EU citizens' received subsidised bus tickets in the first two months of

\footnotetext{
${ }^{78}$ I have not been able to confirm the exact number of people who accepted the offer of a bus ticket. According to a report in Sydsvenskan, at least 19 people travelled by charter-bus to southern Romania in the days before the ultimate demolition of the settlement (Persson, 2015). However, a report from the Social Service Administration of the City of Malmö makes clear that the city approved a total of 60 requests for return trips to Romania in November, 2015. (Sociala resursförvaltningen, 2016, p. 20).

79 'Emergency Social Assistance' (Sw: nödstöd or nödbistånd) is not a legal concept but a shorthand term used to describe assistance (monetary or otherwise) provided to an individual in order to alleviate a temporary emergency situation based on the principle of the municipality's ultimate responsibility (Ch. $1 \S 1$ Social Services Act).
} 
2015 (Malmö stad, 2015, p. 2), followed by another 101 individuals in the eight-month period between July 2015 and March 2016 (Sociala resursförvaltningen, 2016, p. 20) ${ }^{80}$ The practice of providing subsidised bus tickets is also widespread among Swedish municipalities. A 2014 survey conducted by the Swedish Association of Local Authorities and Regions (Sw: Sveriges Kommuner och Landsting) confirms that it is by far the most common form of social assistance offered to 'vulnerable EU citizens' nationally (Sveriges Kommuner och Landsting, 2014). These findings are further confirmed by the National Coordinator for Vulnerable EU Citizens 2016 report. According to the report, municipalities have chartered buses in connection with evictions on multiple occasions (SOU 2016:6, p. 58).

This practice is broadly consistent with the ethos of the EU free movement regulations. As previously discussed, EU citizenship entails a right to move and temporarily reside within another EU member state, but only as long as one does not become 'an unreasonable burden on the social assistance system of the host state' (see the 'Citizenship Directive' 2004/58/EC). These regulations are also incorporated into national law. Furthermore, a consensus has emerged across the political spectrum that the welfare of 'vulnerable EU citizens' who reside in Sweden is ultimately the responsibility of their home countries. When asked to comment on the demolition of the Sorgenfri camp, Prime Minister Stefan Löfven gave the following short answer:

They [i.e., the evacuees] are obviously allowed to come and stay here for a time, but in the long run, their countries have to assume responsibility and make sure they have work, education, and housing in their countries. That is not Sweden's responsibility (cited in SVT Nyheter, 2015, my emphasis).

\footnotetext{
${ }^{80}$ This includes those 60 individuals who were offered bus tickets in the wake of the demolition of the Sorgenfri camp. (See above footnote).
} 
The decision to put the evacuees of the Sorgenfri camp on buses - and thus effectively repatriate them - appears consistent with this standpoint. However, the decision was not as self-evident at the municipal level.

Indeed, I begin the chapter with discussing the practice of free return trips because it provides an interesting example of how the municipal authorities navigate and negotiate the legal ambiguities as well as the moral-political dilemmas that arise in relation to the geographical presence of destitute EU citizens without a definitive right of residence. As I will explain, the laws governing access to social assistance and services at the municipal level are not nearly as clear-cut as the national level immigration and nationality laws. This scalar incongruity has been strategically mobilised by sanctuary cities advocating to claim certain rights for irregular migrants (e.g., rejected asylum-seekers) at the municipal-level, including partial rights to means-tested social assistance (see Nordling, 2012, 2017) ${ }^{81}$ However, 'vulnerable EU citizens', who occupy the threshold between regularity and irregularity, are generally excluded from such forms of support. The policy guidelines issued by the National Board of Health and Welfare (Sw: Socialstyrelsen) state that EU citizens who are staying in Sweden on a temporary basis or who do not have a secure right of residence (Sw: uppehållsrätt) are only eligible to receive support in emergency situations and that 'the primary purpose of emergency social assistance is to give the claimant the opportunity to do something about their situation, like traveling back to the home-country' (Socialstyrelsen, 2017, p. 35, my translation and emphasis). The question is how the municipal authorities draw the line between 'vulnerable EU citizens' and other categories of transient and irregular residents, how they justify these distinctions, and what the practice of putting people on buses tells us about the bordering of the welfare state and the municipality?

\footnotetext{
${ }^{81}$ As I will explain further on, these guidelines were amended in the wake of the so-called 'migration crisis' and are now (in 2019) much less generous than they were in 2015 when the evacuation of the Sorgenfri camp took place.
} 
To begin with, I would suggest that the bus ticket could be understood as a means of exclusionary mobility control, of bordering. To be clear, I am not saying that it is a directly coercive practice, nor that it is actually effective as a means to keep people out. After all, 'vulnerable EU citizens' who accept a free bus ticket are not prevented from returning and reentering the country. It is also entirely possible that some of them genuinely appreciate this form of support. Perhaps, for some, it is simply a free trip home - one that they would have made anyways, but that they would have then had to pay for out of their own pockets. Indeed, the giving out of emergency social assistance in the form of a bus ticket is not the most coercive, nor the most dramatic, measure of mobility control. I am the first to admit this. Nevertheless, it bears questioning why one of the only forms of social assistance that is afforded to 'vulnerable EU citizens' in Malmö (and in Sweden, more generally) is one that effectively functions to repatriate them.

Recent scholarship have called attention to the duality of ostensibly humanitarian repatriation schemes targeted at mobile Roma EU citizens in countries like France and Spain (Carrera, 2014; Vrăbiescu, 2019a, 2019b), and to the ways in which humanitarian and security logics intersect in the governance of Roma mobilities more generally (see Aradau, 2015; Barker, 2017; van Baar, 2017b). Here, we might recall that an element of the widely criticised mass expulsions of Roma EU citizens from France in 2010 was a program of repatriation by which Eastern European Roma - many of whom had first been forcefully evicted from their dwellings - were given cash incentives to return to their countries of origin (Carrera, 2014). Based on research carried out in Spain between 2013 and 2015, Vrăbiescu (2019b) suggests that pay-to-go 'voluntary' return programs that target Romanian Roma might be seen as enabling 'acts of soft-deportation'. According to Vrăbiescu(2019b), free and voluntary returns are generally presented as a benevolent form of assistance. Against the backdrop of a near-complete absence of a strategy for inclusion, such offers combine with other more overtly disciplinary and securitising state practices to create a situation where Romanian Roma migrants have few other choices but to accept the offer and return 
to Romania (p. 216). Something similar could be said of the bus tickets that were given to the squatters of the Sorgenfri camp. Although they were technically free to reject the offer (and some did), it nevertheless functioned - in the absence of other forms of social assistance - as a technology of expulsion.

That said, it would be a mistake to attribute the bus tickets to a direct and explicit policy agenda of immigration control and expulsion. Indeed, if we shift our focus from the rhetoric of the Prime Minister and others to the mundane municipal-level practices of social assistance administration, we discover a more complex picture. In short, the same basic rules that underpin the practice of providing bus tickets to 'vulnerable EU citizens' are regularly applied to homeless or otherwise transient (national) citizens who seek assistance in a municipality where they have no recognised status as municipal residents ( $\mathrm{Sw}$ : kommuninvånare). The main difference is that while the latter is transported to another municipality within the same country (where they would typically have access to more substantial forms of support), the former is repatriated to another country altogether. What this suggests, in theoretical terms, is a more complex arrangement of social entitlements and rights than is captured by fixed and hierarchical scalar conceptions of nationalised 'social citizenship' (Marshall, 1950) and of the welfare state. It also foregrounds the city (or more accurately the municipality) as a space where the boundaries and contents of citizenship are continuously negotiated.

\section{Negotiating Residency and Rights in the Municipality}

In a reflection on citizenship beyond the state, Isin (2007) argues against a powerful and predominant understanding of the relationship between the city and the state that he calls 'scalar thought'. The core assumption of scalar thought is that the (nation-)state is the territory in which citizenship is held. From this also follows the idea that 'since citizenship is universal regardless of where one is in that territory, there can be no legal rights or obligations arising from any other scale than the state' (Isin, 2007 , p. 218). Thus, the city qua the municipality comes to appear as an 
administrative sub-unit within and below the state, largely irrelevant to the politics of citizenship and social rights. However, what Isin (2007) argues is that citizenship is first and foremost an effect of practices: 'it is as much about belonging, identity and social status' as it is about fixed 'juridico-legal status' (p. 219). In Isin's perspective, the city - rather than the state - is the preeminent site for the struggle over citizenship because the city is the primary scale of social experience and practice, an actuallyexisting and lived space. In contrast, the state is a virtual, imaginary entity; it is real only in the sense of being realised through border walls, checkpoints, mandatory education, taxation schemes, and maps. According to Isin (2007), 'the state as an actual entity does not exist' (p. 221; see also Isin, 2002). ${ }^{82}$ Here, I am not so much interested in making a theoretical argument about the epistemology of citizenship and the state. What I appreciate about Isin's theory though is that it emphasises the concreteness of cities (see also Ang, 2006). For Isin, the city is the space where the injustices and exclusions of citizenship in its institutionalised form both manifest and are contested. In his own words, 'the city is the battleground through which groups define their identity, stake their claims, wage their battles and articulate citizenship rights, obligations and principles' (Isin, 2007, p. 233; see also Isin 2002, pp. 283-284; Sassen, 2003, 2013). A key example of this would be the sanctuary cities movements, which mobilise for the extension of rights and protections to refugees and undocumented migrants. As previously mentioned, there is an active migrant justice and sanctuary cities movement in Malmö that has managed, in the past, to secure certain provisional and partial rights to means-tested social assistance for undocumented migrants (see also Lundberg \& Dahlquist, 2018; Nordling, 2012, 2017).

\footnotetext{
${ }^{82}$ Isin's argument rests on the distinction between the 'actual' and the 'virtual' found in the work of both Gilles Deleuze and Jacques Derrida. Isin suggests that whereas the state (along with other bodies politic like nations, leagues, federations, and empires) exist only as virtual entities, the city is both virtual and actual. Its actuality derives from its materiality and physicality (the urbs). As the site of actual material/physical encounters between people, the city becomes the site where citizenship is effectively made through various concrete practices.
} 
Broadly speaking, sanctuary movements and practices actively contest the exclusions of national-level juridico-legal citizenship and raise fundamental questions about what Arendt (1951) called 'the right to have rights'. There is a rich literature on the politics of hospitality that underpins the sanctuary cities movements, including work that brings attention to the unequal relations of power inherent in acts of hospitality (Dikec, Clark, \& Barnett, 2009; Squire \& Darling, 2013; Strange \& Lundberg, 2014). Here, I would like to focus on the more overly geographical dimension of sanctuary claims. As Darling (2017) notes, such claims, which are frequently couch in a language of hospitality or 'the right to the city', tend to rely on and reinforce certain restrictive notions of residency (p. 13). There are many examples globally of how undocumented migrants have attempted to claim rights by insisting that they are already de facto longstanding and stable residents of a given locale (see for example Balibar, 2004; Holgersson, 2011; Nyers, 2010). While such notions of local citizenship and residency are often more open and inclusive than national-level citizenship, they are also crucially bounded. Darling (2017) thus asks us to consider claims that articulate ideas of membership based simply on geographical presence - on the fact of being here. Citing examples of migrant justice movements along the United States-Mexico border that are fighting for the right to come and go (as opposed to a right to come and stay), Darling (2017) proposes the notion of a 'politics of presence': a demand for participation, rights, and mobility. I would suggest that the claims made by the squatters of the Sorgenfri camp (e.g., claims for social assistance and access to an alternative campsite) can be usefully understood in these terms.

The notion of a 'politics of presence' resonates closely with what legal theorist Linda Bosniak (2007) calls 'ethical territoriality': 'the conviction that rights and recognition should extend to all persons who are territorially present within the geographical space of a national state by virtue of that presence' (pp. 389-390). This concept is mainly useful to understand rights claims made by variously irregularised migrants, but it also helps us to theorise ambiguities and contradictions inherent to a given rights regime. Bosniak (2007), suggests that debates about immigrants' 
rights can be usefully analysed as an 'incessant tug-of-war' between two different ideal-type conceptions of membership and rights: a territorially based conception (i.e., ethical territoriality) and a status-based one (p. 392). The latter, status-based conception, treats membership as a strictly formal status under law. Accordingly, a person's rights are determined by the specific legal category they occupy in the country's immigration and nationality regime. As Bosniak (2007) notes, this conception allows for a differentiated and graduated forms of membership: from full citizenship to various lesser statuses (p. 390). In contrast, the territorially based conception takes geographical presence - the fact of hereness - as sufficient basis for core aspects of membership. By this conception, membership becomes more of a binary: either you are here, or you are not. ${ }^{83}$ Bosniak (2007) argues that 'ethical territoriality' is preferable to the status-based conception of rights on strictly liberal democratic grounds (pp. 389-390). He adds,

Ethical territoriality is especially valuable in its effort to acknowledge and honour the real attachments people develop in their daily lives, in its commitment against the perpetuation of caste in democratic political communities, and in its insistence on ensuring individual protections against the exercise of state power. ( p. 409)

However, ethical territoriality also contains a constitutive exclusionary element. According to Bosniak (2007), 'almost every version of inclusion-within-the-territory is coupled with a vision of a bounded territorial community within which inclusion is to take place' (p. 395). Thus, it is entirely possible to be in favour of some version of ethical territoriality and simultaneously affirm the legitimacy of exclusionary controls at the edges and of a given territory. This makes ethical territoriality 'self-undermining in practical terms'. It insists on equal rights and recognition for everyone who is present within a given territory, but it fails to come to terms with 'the defining condition of

\footnotetext{
${ }^{83}$ Significantly, these are theoretical models, ideal types. In practice, the two conceptions often converge (see discussion in Bosniak, 2007, p. 391).
} 
alienage itself' - the possibility of being denied entry or removed from that territory (p. 409).

In the following section, I will discuss how the various categories of municipal residency found in Swedish law, first of all, do not overlap neatly with the categories of national-level citizenship. While the latter are rather clear-cut, formal statuses, the former sit somewhere on the threshold between Bosniak's ideal-type status-based and territorially based conceptions. Significantly, the Swedish Social Services Act (2001:453) includes an explicit concept of 'stay' or 'presence' (Sw: vistelse). This specific concept has been mobilised by migrant justice advocates to claim provisional rights to means-tested social assistance (i.e., monetary allowances) for irregular migrants at the municipal level. However, the authorities have been unwilling to extend such forms of support to 'vulnerable EU citizens'. As I will argue, this makes clear the fundamental contradictions of territorialised rights and points to the ways in which the municipality is actively bordered.

\section{'The Principle of Ultimate Responsibility' and the Ambiguity of the Categories of Residency}

The discrepancy between national-level citizenship and municipal residency - and the innate ambiguities of the categories of residency has two noteworthy implications. It presents an opening for variously irregularised migrants to make claims for membership and rights at the local level.$^{84}$ It also means that individuals who are citizens but unable to

\footnotetext{
${ }^{84}$ A clarification on terminology: In the Swedish language there are separate words for the categories of residence status found in immigration law, and the concept of municipal residency that is found in, for example, the Local Government- and Social Services Acts. The term uppehållstillstånd (literally 'residence permit') is generally used to denote that someone has a formal right to remain under immigration law. For my purposes, it can usefully be understood as a lesser national-level citizenship status. The 'right of residence' (Sw: uppehållsrätten) is a separate status reserved for EU citizens. Much like a residence permit, it formally confers a right to remain in the country. However, because it is contingent upon one's socio-economic status (i.e., whether one is self-sufficient or a 'burden on the social assistance system') it is in practice very difficult to draw a strict line between those who have and those who do not have a legal right of residence. In comparison to these statuses, municipal-level 'residency' (Sw: bosättning) is a more fluid concept. The word itself - bosättning - is a nounified version of the verb 'settle' or 'dwell' (Sw: bosätta). And again, it sits somewhere between a formalised status and a social fact. Over the years, there have been numerous attempts by the legislator and courts to clarify the exact meaning of the term. Currently, a distinction is made between
} 
prove (local) residency might be denied access to social assistance and services that they are theoretically entitled to.

The Swedish Social Services Act - the framework law that governs access to social assistance and services - refers mainly to the category of 'residency'. The Act sets a framework in which the municipalities are responsible for organising (and financing) social assistance and services, which allows for a degree of autonomy and discretion on the part of municipal authorities. Notably, the law does not contain a single explicit mention of citizenship. This reflects the decentralised character of the Swedish system of social assistance and service provision, a legacy of the early modern, parish-based poor relief system (Sahlin, 1996; Swärd, 2008; Wikström, 2015). The right to social assistance is defined in the law as a last resort for individuals 'if they cannot meet their own needs, or needs could not be met otherwise' (Ch $4 \S 1$ SSA). ${ }^{85}$ This implies that an individual in need can receive social assistance from the municipality only if no other entity (e.g., another state agency) can be deemed responsible. Generally speaking, claimants also need to be able to prove their residency in a given municipality to qualify for full social assistance and services. For most of us, this is not generally a problem. A registered address is typically regarded as sufficient proof of residency. However, for transient individuals who do not have a registered or stable address, this requirement can sometimes act as a real and significant barrier to access. Not surprisingly, those who are most affected by this issue are also those who are already severely disadvantaged, those who most need support. A typical example of someone at risk of being denied access

\footnotetext{
a) formal residency as registered address, and b) residency as settlement, defined on the basis of where you usually spend your daily rest time ( $\mathrm{Sw}$ : dygnsvila). There is also a third category of residency: 'presence' (Sw: vistelse) which is taken to refer to the simple fact of being or staying temporarily in a given location (SOU 2009:38). In the remainder of this chapter, I will use the term 'residency' as an umberella term for the various categories of residency found in municipal law, and treat 'citizenship' as a shorthand for the various citizenship and residence statuses of immigration and nationality law.

85 'The explicit aim of the right as expressed in Ch. $4 \S 1$ SSA is to be assured of a reasonable standard of living, and the assistance should be designed to strengthen the individual's ability to live independently. This is what is covered for the individuals eligible for full social assistance, which could be compared to the assistance for acute or emergency need given to those who are not given residence status.'
} 
would be a transient homeless person, but the problem does not only affect the homeless. A 2009 government inquiry (SOU 2009:38), entitled 'No one should have to be Black Peter' (Sw: Ingen fär vara Svarte Petter), found that it was common for individuals with uncertain residency status to be treated like the 'Black Peter' of the card game, as municipalities would busy themselves trying to prove an applicant's ineligibility rather than assessing their needs. ${ }^{86}$

In theory, it should not be possible for people to fall through the cracks like this. The Swedish Social Services Act includes a clause ( $2 \mathrm{ch} .1 \S)$ on 'local responsibility', which specifies that 'the municipality is ultimately responsible for making sure that those who are present ( $\mathrm{Sw}$ : vistas) in that municipality have access to the support and assistance that they need' (my translation and emphasis). This is referred to as the 'principle of ultimate responsibility', and it could be said to represent a mechanism of basic humanitarian protection and care. It makes it incumbent on the social service administration of a given municipality to address the acute needs of those who are geographically present within their jurisdiction, regardless of their residency status (see Kjellbom \& Lundberg, 2018; Wikström, 2015).

However, the concept of presence that underpins the principle of ultimate responsibility has proven to be a slippery one. The aforementioned government inquiry (SOU 2009:38) was commissioned precisely to clarify the 'principle of ultimate responsibility' in order to prevent transient citizens from being excluded from services. To this end, the inquiry report proposed to further formalise the definition of residency and to clarify the distinction between the categories of residency and presence. The inquiry ended on a proposal to clarify that the rights of

\footnotetext{
${ }^{86}$ The racial connotations of the title of the report are regrettable. Svarte Petter/Black Peter is a card game, also known as Old Maid. It is played with a special pack of cards. All the cards in the pack come in matching pairs except one (Black Peter/Old Maid), whose holder at the end of the game is the loser. I have translated the title of the report (Ingen får vara Svarte Petter) as 'no one should have to be...' because it looks and sounds most similar to the original. A more exact translation would be 'There must be no Black Peter', the implication being that no one should be treated like a Black Peter.
} 
those who are not able to prove residency status should be limited to emergency support only. A second clause on local responsibility was added to the Social Services Act, which reads as follows: 'If it is clear that a municipality other than the one of presence is responsible for assistance and support for an individual, the responsibility of the municipality of presence is limited to emergency situations' (Ch. $2 \mathrm{a} \S 2$ SSA). In the inquiry report, this is further specified as follows:

\begin{abstract}
Emergency support and assistance is primarily intended for the individual to be able to return to his/her municipality of residence (Sw: bosättningskommun), e.g., help arranging a return journey. It can also be accommodation or food money until departure. If the individual cannot or does not want to return immediately, the municipality of stay (Sw: vistelsekommun) remains responsible for emergency support and assistance as long as the individual remains in the municipality.
\end{abstract}

In light of this, we might conclude that the practice of providing bus tickets to 'vulnerable EU citizens' is continuous with how the Swedish municipalities' treat other non-residents, be they citizens or not. It serves as a telling example of municipal bordering - one that is reminiscent of the territorial demarcations, exclusions, and control practices that defined the early modern poor relief system (Sahlin, 1996). The irony of the practice at hand is that although 'vulnerable EU citizens' are often rhetorically cast as migrants and outsiders to the state, they are technically treated on the same terms as some Swedish citizens who are, at least nominally, considered insiders. I would therefore argue that this small example goes some way to show the inherent instability of the common binary division between citizens and migrants and the ways in which exclusions from without are entangled with exclusions from within (see Anderson, 2017, p. 1535).

\title{
At the Threshold of the Threshold
}

Before I conclude this first part of the chapter, I would like to also consider how the figure of the 'vulnerable EU citizen' troubles sanctuary policies and their associated categories of migrant irregularity. As stated earlier, the ambiguity of the categories of residency found in the Social 
Services Act presents an opening for variously irregularised subjects to claim social rights at the local level (Lundberg \& Dahlquist, 2018; Nordling, 2012, 2017). In fact, the City of Malmö was one of the first municipalities in Sweden to implement policies that explicitly address the situation of irregular migrants. In November 2013, the City Council voted on a new set of guidelines that articulated and codified a partial and provisional right of irregular migrants to access means-tested emergency social assistance (Malmö stad, 2013; see Nordling, 2017, pp. 149-180 for an analysis). In simple terms, these guidelines relied on a scalar differentiation of obligations between the municipal-level Social Service Administration and the immigration authorities. It also rested on the assumption that undocumented migrants, as de facto residents, should have a right to apply for social assistance. Notably, the guidelines included EU citizens without a right of residence in the overall category of 'undocumented migrants'. The following is an excerpt from the document in question:

Undocumented migrants lack legal residence in Sweden. The responsibility of the social services is therefore limited to support and help in acute situations (emergency) when the person resides in the municipality ( 2 a Chapter $2 \S$ Social Service Act). What types of support and help are considered as acute shall, in the same way as with other persons subject to the regulation, be assessed through individual assessment. There are no special regulations for undocumented migrants; they should be treated in the same way as other persons residing in the municipality and applying for support from the social services. The ultimate responsibility of the municipality remains as long as the person resides in the municipality and does not get her/his need met in another way. (Malmö stad 2013, translation by Nordling, 2017, p. 150-151).

While the municipal guidelines made no explicit distinction between 'vulnerable EU citizens' and other categories of irregular migrants, a practice appears to have developed at the administrative level of differentiating between the claims of EU citizens and those of other categories of irregular migrants (Nordling, 2017, p. 312). This is difficult to evidence empirically, but I know from being actively involved in support work with undocumented migrants (i.e., rejected asylum seekers) 
from Afghanistan and Iraq that it used to be possible for individuals belonging to these groups to receive emergency support in the form of a monetary allowance. The guidelines in question have since been revised, but in 2015 when the Sorgenfri camp was evacuated, it was still the case that some undocumented migrants could count on receiving this type of support on a regular basis. According toNordling (2017), this suggests that the administration implicitly reinterpreted the concept of emergency from a one-time event to a lasting situation (p. 152).

Here, the differential treatment of 'vulnerable EU citizens' raises a basic question: why should the norm, as established in administrative practice, be different for 'vulnerable EU citizens' than for other categories of irregular migrants? The formalist answer appears straight-forward: National policy guidelines (such as the ones that have been issued by the National Health and Welfare Board) suggest that a return trip should be the first option when considering how to interpret the principle of ultimate responsibility (see Socialstyrelsen, 2014, 2017b). Only when this is not practically possible would it be relevant to consider extended forms of emergency support to non-residents (e.g., in the form of a recurrent monetary allowance). Going beyond a strictly formalist analysis to consider what the differential treatment of 'vulnerable EU citizens' and irregular migrants represents, I would suggest that it speaks to the inbetweenness and profound undecidability of the category of the 'vulnerable EU citizen'. Hansson and Mitchell (2018) refer to this as a 'state of doubly negated liminality' (p. 24). If differently categorised irregular migrants (e.g., rejected asylum seekers) can claim rights to the fulfilment of humanitarian needs on the very basis of their undocumentedness (i.e., their absence of citizenship), 'vulnerable EU citizens' are disqualified from such rights precisely on account of their status as citizens of the EU. In this sense, 'vulnerable EU citizens' can be said to occupy the 'threshold of the threshold': they are neither recognised as irregular migrants nor effectively treated as full citizens (Hansson \& Mitchell, 2018, p. 24; cf. Lind \& Persdotter, 2017). This returns us to the contradiction at the heart of EU citizenship and free movement regulations, namely the fact that the legal right of residence is contingent 
on socio-economic status such that those who are deemed to be economically inactive or a burden on the social assistance system of their host member state are effectively excluded from this right.

The specific practice of providing emergency social assistance to 'vulnerable EU citizens' primarily in the form of a return trip also brings into question the contradictions and limitations of territorialised rights for irregular migrants. After all, what good is the right to social assistance (i.e., a right based on presence) if it only entitles you to a form of assistance (i.e., a return trip) that effectively displaces you so that you are no longer territorially present? In 2017, I published an article together with my colleague Jacob Lind in which we analysed a parallel example of differentiated rights for 'vulnerable EU citizens' and other categories of irregular migrants (see Lind \& Persdotter, 2017). In the article, we scrutinised the National Coordinator for Vulnerable EU Citizens, Martin Valfridsson's, arguments for excluding 'children of vulnerable EU citizens' from the right to schooling in Sweden, comparing these arguments to the recommendations found in the pre-works ( $\mathrm{Sw}$ : förarbetena) of a 2013 legislative amendment which extended an unrestricted right to education to 'all children who reside in Sweden without permission'. We asked how Valfridsson could justify that one group of children (i.e., 'the children of vulnerable EU citizens') should be excluded from education when it has been defined as an elementary right of all children residing in Sweden. Starting from the observation that the putatively free cross-border mobilities of 'vulnerable EU citizens' raise the spectre of the Swedish state collapsing under the pressure of 'povertyor welfare migrants', we observed that Valfridsson and other state actors have attempted to delimit the rights of 'vulnerable EU citizens' (be they children or not) to access public services as an indirect means to discourage their immigration (see also Lafleur \& Mescoli, 2018). By the reverse token, we also noted that the Swedish state appears to be willing to extend certain rights to irregular migrants on the basis of their territorial presence only as long as their presence itself remains conditional - that is, only as long as they remain deportable. In fact, the rights of undocumented migrants to access education and health care in Sweden 
are explicitly based on their status as 'deportable' (cf. Lundberg \& Spång, 2017). The example of the right to education is not completely analogous to that of the bus ticket, but it bears some striking similarities. Arguably, the practice of putting 'vulnerable EU citizens' on buses back to their home countries can be understood as yet another example of the instrumentalisation of social rights in the context of the current Swedish migration regime. I will admit that this is a somewhat speculative argument, but a couple of recent developments supports this conclusion.

The first one concerns, once again, the rights of 'vulnerable EU citizens' to access social assistance. While all existing policy guidelines emphasise that claims for social assistance should be assessed on a case-by-case basis, it is a known fact that some Swedish municipalities have instead issued bus tickets to whole groups of people in connection with, for example, an eviction or a sudden onset of bad weather. The report of the National Coordinator for Vulnerable EU Citizens indicates there are several known cases of this happening and stresses that there is strictly no basis in law for such group-based assessments (SOU 2016:6. p. 60). In February 2015, I attended a conference of the Swedish Association of Local Authorities and Regions, where there was much discussion about the rights of EU citizens to claim subsidised return trips. Several of the participants, who were there as representatives for different Swedish municipalities, expressed concerns that the opportunity to claim return trips would be exploited, and some described having implemented a kind of unwritten policy whereby they would only allow one paid-for return trip per person (field notes, February 4, 2015). I have not been able to follow up on this to verify how widespread such unwritten policies are or have been. Strictly speaking, they would be discriminatory and unlawful, and my impression is that there has been a concerted effort on the part of, for example, the National Coordinator for Vulnerable EU Citizens to make sure municipal public officials are abiding by the requirement to assess claims individually. Nevertheless, the unwritten policies in question are telling of a more widespread tendency to problematise the circular mobilities of vulnerable EU citizens as excessive and undesirable, 
and it goes to show how rights provisions are re-envisioned as measures of mobility control.

The second development relates back to the contradictions of territorialised rights. With the unprecedented influx of asylum seekers in 2015 - many of whom have since been denied asylum and thus rendered irregular - the rights of variously irregularised migrants to access certain forms of social services (not just municipal social assistance but also other forms of support) have been restricted. More and more, it seems that the entitlements of rejected asylum seekers and other migrants are rolled back to make it more difficult for them to remain in the country. One example is the 2016 amendment of the Reception of Asylum Seekers Act (Sw: Lagen om mottagande av asylsökande), which stripped rejected asylum seekers of the right to remain living in accommodation provided by the immigration authorities and to access other basic services while they await deportation, leaving a large group of people homeless or at risk of homelessness. In 2017, the Swedish Supreme Court of Appeal issued a decision which states (contrary to previous case law) that the municipal social services should not provide regular social assistance to irregular migrants (see analysis in Kjellbom \& Lundberg, 2018). Locally, in Malmö, the City Council has also revised the previously existing guidelines on social assistance to irregular migrants and proposed a more restrictive interpretation of the rights of rejected asylum seekers and others to access emergency support.

Up to this point, I have discussed the rights of EU citizens without a legal right of residence to access individual, means-tested emergency social assistance. In brief, the group in question is only entitled to minimal and temporary forms of social assistance, and support is usually given in the form of a bus ticket to the applicant's home country. This is the result of multi-scalar negotiations. It reflects the fundamental limitation of the freedom to move and reside attached to the status of EU citizenship, namely that these rights are restricted in such a way that seeking social assistance in another member state means that you effectively forfeit your very right of residence (cf. Zahn, 2015). This exclusion is compounded at 
the local level by the treatment of 'vulnerable EU citizens' as nonresidents. The practice of providing emergency social assistance only in the form of a bus ticket is telling of the in-betweenness and undecidability of the category of the 'vulnerable EU citizen': They are neither recognised as irregular migrants nor effectively treated as full citizens.

In what follows, I would like to shift focus from the entitlements of individual 'vulnerable EU citizens' to discuss a number of local initiatives and policy developments that have taken place over the last several years to address the presence and situation of 'vulnerable EU citizens' on a broader scale. As I will explain, a policy program has emerged over the years (roughly between 2014 and 2016) that mixes benevolent and humanitarian initiatives with disciplinary and securitising measures. On the one hand, the City of Malmö funds a service centre and a winter-time homeless shelter for 'vulnerable EU citizens'. On the other hand, the authorities have developed a policing strategy aimed specifically at preventing the re-establishment of settlements like the Sorgenfri camp, a local level zero-tolerance approach towards unauthorised settlements. Below, I trace the gradual development of this dual policy and discuss what I see as a 'meeting and meshing' of humanitarianism and exclusionary or securitising measuress. ${ }^{87}$

\section{A Dual Approach: Local Initiatives and Policy Developments in Malmö, 2014-2016}

Compared to Stockholm and Göteborg, the other two major urban municipalities in Sweden, the City of Malmö was relatively late to develop policies and services in relation to the presence and situation of 'vulnerable EU citizens'. Before 2014, the city had no policies that specifically addressed the group in question. There were also no services specifically geared towards 'vulnerable EU citizens'. According to several of my informants, this was because for a long time there were

\footnotetext{
${ }^{87}$ I borrow the expression 'meeting and meshing' from Vanessa Barker's work on benevolent violence. Barker has taken the term from Loic Wacquant's work on the continuum of racialised social control from ghetto to prison (Wacquant, 2001).
} 
relatively few EU citizens who were begging and living on the streets in Malmö. At least, the municipal authorities were not aware of their presence. ${ }^{88}$ As was explained to me by a former street outreach worker with the City of Malmö, the established practice within their unit prior to 2014 was to not do any direct outreach work with EU citizens: 'It was made very clear to us, we do not work with this group, and they should not receive any services from the municipality' (interview with Social Worker/Municipal Coordinator for Vulnerable EU Citizens, September 7 , 2015). However, as the number of EU citizens who were begging and living on the streets of the city grew, this implicit policy became increasingly untenable.

The Skåne City Mission (Sw: Skåne stadsmission, hereafter the City Mission) began to ring alarm bells during the winter of 2013/2014. The City Mission is a Christian charity that offers a variety of social services and supports to street-homeless individuals. The organisation is part of a longstanding public-private partnership with the City of Malmö, and it receives a significant portion of its funding directly from the municipality. The money is used to run one of the city's few community centres for street-homeless individuals, called Café David. Here, people can come and eat breakfast, take a shower, and do laundry. For many years, the City Mission also operated a short-term shelter, called Nattjouren, with room for about 25 people in situations of acute homelessness. The funding for this came directly from the city. ${ }^{89}$ During the winter of 2013/2014, the organisation experienced a sudden and significant increase in the number

\footnotetext{
${ }^{88}$ As a comparison, the charity organisation Stockholm City Mission opened a meeting place (Crossroads Stockholm) specifically targeted towards the needs of homeless EU citizens already in 2010. A similar centre opened in Göteborg in 2012. According to a 2012 survey conducted by the Stockholm City Mission (Stockholms Stadsmission), the municipal authorities in Malmö were aware of the presence of homeless EU citizens in the city in 2012. That year, the municipality assisted five destitute EU citizens by paying for return trips back to their countries of citizenship. As is stated in the report, however, the group in question had not yet 'emerged as a problem' for the city's homelessness outreach teams and services (Stockholms Stadsmission, 2012, p. 22).

${ }^{89}$ The shelter (i.e., Nattjouren) closed down in 2018 after the municipality renegotiated their contract with the City Mission, substantially lowering their funding to reduce the number of beds at the shelter (Skåne Stadsmission, 2018).
} 
of visitors to both Café David and Nattjouren. While their regular clientele include many chronically homeless individuals, a large share of the newcomers were reportedly homeless EU citizens. The increasing number of visitors put a strain on the budget and resources of the City Mission and sparked tensions between long-time visitors and newcomers (see Ovesen, 2014).

As a first response to the situation, the City of Malmö Homeless Outreach Team (Sw: Uppsäkarverksamheten) approached the City Mission, along with a number of other NGOs, to initiate a dialogue. This resulted in a joint proposal to either create a day-time resource centre for the 'target group' at the City Mission's existing venue (Café David) or set up a new meeting-place exclusively for homeless EU citizens, modelled on the Crossroad centres in Stockholm and Göteborg (see Malmö stad, 2014, p. 3). The City of Malmö also tasked two members of the Outreach Team with mapping the situation and needs of vulnerable EU citizens in the city.

\section{The 2014 Report 'Socially Vulnerable EU Citizens in Malmö - Their Situations and Needs'90}

The two outreach workers undertook a short but intensive fieldwork study during the spring and summer of 2014, where they interviewed people who were begging, collecting bottles, or selling the street newspaper Faktum. They also interviewed individuals who were living in unauthorised tent encampments. A majority of the informants were identified as Romanian Roma, but the team also encountered several 'third-country nationals' from the Balkans and from countries in Africa (Malmö stad, 2014, pp. 3-4).91 The results of their efforts were presented in a report to the City Council in August 2014. It is entitled 'Socially Vulnerable EU citizens in Malmö: Their Situations and Needs' and represents one of the first concerted efforts on the part of the municipal authorities to address the situation ( $\mathrm{Sw}$ : behov) of 'vulnerable EU

\footnotetext{
${ }^{90}$ The original Swedish title is 'Socialt utsatta EU-medborgare i Malmö - deras situation och behov'

${ }^{91}$ The exact countries are not specified in the report.
} 
citizens' in the city.$^{92}$ Notably, the report does not make any direct policy recommendations. It is largely based on interview excerpts and focuses mainly on the informants' reasons from coming to Malmö and their immediate needs and desires in terms of housing, health care, and work. There is also a sub-section that highlights the specific situation of parents who have brought their children with them.

As I re-read the report in 2019, I am struck by the fact that the informants are identified as job-seekers and that the report explicitly addresses issues related to their access and integration into the domestic labour market. As I mentioned in the introduction, this perspective is not a very pronounced one in the national-level policy discourse. For example, it is largely absent from the 2016 report of the National Coordinator, Martin Valfridsson, where the category of 'vulnerable EU citizens' is instead defined as being wholly outside the labour market. ${ }^{93}$ In the local report, however, a number of the informants speak of how disappointed they are that they have not been able to find work in the city. Some also report that they have faced barriers (e.g., language difficulties and possibly discriminatory treatment) when attempting to register with the Public Employment Service ( $\mathrm{Sw}$ : Arbetsförmedlingen):

We have come here to work, not beg. We are tradesmen. I am a driver, he has worked in construction, and he is a floor layer. ('Man, 30 years old, quoted in Malmö stad, 2014, p. 17)

\footnotetext{
${ }^{92}$ The study had three aims. The primary one was to count how many 'socially vulnerable EU citizens' there were in the city and assess their needs in terms of social services. Additionally, the study sought to clarify the rights situation of the category in question, particularly in terms of their mobility rights and their rights to access publicly provided social assistance and services. Finally, the study aimed to gather information on initiatives and policy developments in other cities. The report acknowledges and addresses the methodological difficulties involved in operationalising the category of 'socially vulnerable EU citizens'; it focuses on street homeless individuals but notes that it is difficult - not to say impossible - to draw a clear line between this groups and other individuals and groups of EU citizens and third-country nationals with precarious work and living conditions.

${ }^{93}$ The 2016 report of the national coordinator defines the a 'vulnerable EU citizen' as one who does not have a right of residence in Sweden because they do not have job or 'good prospects of finding a job' (SOU 2016:6, p. 13). This is the Eurostat definition of 'economically inactive' EU citizens - those who are neither employed nor unemployed.
} 
We visited the employment agency. But there was no Romanian interpreter, instead they gave us a Spanish one. We received no help. We were sent here and there. ('Man, 40 years old', quoted in Malmö stad, 2014, p. 17)

Overall, the 2014 report centres on the self-reported needs and wishes of 'socially vulnerable EU citizens'. In other words, they were framed within a humanitarian discourse as individuals with real and potential needs for assistance and services. Many of the informants quoted in the report express having significant difficulties meeting their basic needs for food, shelter, sanitation, and health care, and several assert that they would like to have access to a stable and safe place of dwelling ( $\mathrm{Sw}$ : boplats) where, as one informant out it, 'we can know that we will not be chased away' (Malmö stad, 2014, p. 8). Some also describe that they would like to be able to brings their children with them and for their children to be able to go to school in Malmö. The following is an interview excerpt from the report:

Now there is no water, we cannot wash ourselves. Now we go to gas stations and to public lavatories, but we are too many - there is not enough time for all of us. We wash once a week. It is really difficult to find places where we can wash our clothes. Some of us go to Värnan [a meeting place for homeless people at Nobeltorget, run by the municipality]. But it is difficult to know where everything is, not all of us know our way around. We are also afraid that the police will show up at Värnan. It is difficult to go there because there are other visitors who do not want us there. We would like to have a place that is oriented towards us and our needs. ('Man, 60 years old', quoted in Malmö stad, 2014, p. 9).

While the report highlights a gap between the needs and rights of 'socially vulnerable EU citizens', it does not make any direct recommendations for how to address these needs. For the most part, it stops at affirming they exist. That said, the report emphasises that because "socially vulnerable EU citizens' have no rights to public services, they end up relying on services provided by the voluntary sector - where they are in competition for already scarce resources with other similarly marginalised members of society, especially the more established chronic homeless population. 
It also notes that further inaction on the part of the municipal authorities will negatively impact other socially vulnerable groups and create further tensions between them and 'vulnerable EU citizens' (Malmö stad, 2014, p. 20). The report concludes as follows:

As we see it, both the problems and the solutions lie at several different levels. It is a question of what the situation is like in the home countries, about racism and discrimination, and the opportunities for them to make a livelihood there. Big questions that need to be addressed at the EU level. [At the national level we see that] there are differences between different cities and regions in terms of what services are made available to EU citizens. Here we see a need for a coordinated strategy to be decided on at the national-level. But we also have a local problem and a local responsibility. These people exist in Malmö, and they have needs that are not being met. There has been an increase [in the number of people] and currently there is nothing that indicates that this increase will subside. Therefore, decisions need to be made about what to do here and now. (Malmö stad, 2014, p. 22).

I include this last, somewhat lengthy, quote because it speaks to the 'dynamic concreteness' (Ang, 2006, p. 33) of the city: the everyday and pragmatic quality of urban life and governance. The problems are here and now, and they seem to demand an immediate response. This, in turn, tells us something about the politics of urban citizenship. Again, if national-scale citizenship is generally defined as a formal demarcation of membership and rights (i.e., a status) with relatively clear-cut distinctions between citizens and non-citizens (Joppke, 2007), such distinctions are frequently untenable at the embodied and lived scale of the city (Ang, 2006; Isin, 2002, 2007). As Isin (2007) explains, this is because citizenship as a juridico-legal status can never fully capture and contain the everyday enactments of citizenship: 'bodies social always overflow, decode and recode the bodies politic that are created and maintained to contain them' (p. 218). In other words, 'vulnerable EU citizens' may not have a legally defined right to access social services, but they are nevertheless here and now, making direct or indirect claims for support and services. Their very presence demands a response, and decisions need to be made about what to do. 
An important question to ask in this context is what kinds of policy responses (or solutions') are actionable at the municipal level. Here, I would like to recall Valverde's $(2009 \mathrm{a}, 2010)$ theoretical argument about the games of scale, which she notes 'work so silently and efficiently' that we often do not think of asking what would happen if matters like garbage disposal, public transit, and the signs of street-homelessness were reimagined as national- or supra-national policy issues rather than as matters for urban regulation (2009a, p. 146). We also do not think of asking, if we go in the opposite direction, what would happen if structural inequality and racism were treated as issues that required distinctly local policy responses. The above-cited excerpt from the 2014 report reveals the scalar differentiations that are routinely made in the public and policy discourse about 'vulnerable EU citizens' in Sweden. The 'big questions' of racism, discrimination, and labour-market integration are assumed to properly belong at the EU level or, alternatively, in the home countries. At the same time, the national level is identified as a crucial one for policy harmonisation ('a coordinated strategy'). However, the central state is rarely ever called upon to provide direct forms of support to the group in question. Instead, the municipality (in this case, the City of Malmö) is almost as if by default designated as that level of government that should be responsible for addressing the acute needs of 'vulnerable EU citizens', along with the ostensibly 'local problems' associated with the group in question (cf. argument in Spehar et al., 2017). It bears noting that this scalar differentiation involves an implicit - but, I would argue, consequential - splitting of the core questions of inequality and racism from the domain of municipal policy-making and administration. It also affects what kinds of solutions becomes thinkable, and the scale thereof.

\section{Steps Towards a Coordinated Policy}

Following the publication of the 2014 report, the Social Service Administration created a full-time coordinator position for issues concerning 'socially vulnerable EU citizens'. The position ended up being shared by the same two outreach workers who wrote the initial report. They were tasked with mapping and integrating the municipality's various initiatives and interventions and liasing with other public 
authorities and civil society actors. Early on, they set a goal to develop a comprehensive action plan. The coordinators also assembled four thematic networks that would meet on a number of occasions in the first half of 2015 to devise a coordinated strategy on issues relating to the presence of 'vulnerable EU citizens' (interview with Social Worker/Municipal Coordinator for Vulnerable EU citizens, Sep 7, 2015). Below is a list of the networks and their participating organisations. It gives a picture of the complex web of administrative relations that was mobilised in response to the 'question of vulnerable EU citizens'.

1. Emergency preparedness network. This network brought together a number of different government organisations to develop an emergency preparedness plan. Participating organisations included,

- The City of Malmö Unit for Safety and Security (Sw: Avdelning trygghet och säkerhet)

- The City of Malmö On-Call Social Services Division (Sw: Social Jour)

- The unit for disease control at the Region of Skåne (Sw: Smittskyddsläkare)

- The regional Fire and Rescue Services (Sw: Räddningstjänsten syd)

2. Settlement network. This network focused on developing a coordinated strategy for handling unauthorised settlements. Participating organisations included,

- The City of Malmö Unit for Safety and Security (Sw: Avdelning trygghet och säkerhet)

- The City of Malmö On-Call Social Services Division (Sw: Social Jour)

- The City of Malmö The Homeless Outreach Team (Sw: Uppsökarverksamheten)

- The City of Malmö Environmental Administration (Sw: Miljöförvaltningen)

- The City of Malmö Traffic Department (Sw: Gatukontoret)

- The Enforcement Authority (Sw: Kronofogden);

- The Police (Sw: Polismyndigheten) 
3. Individual and Family Care. This network focused specifically on issues concerning children.

a. Representatives from the City of Malmö Individual and Family Care Services (various units)

b. The City Office (Sw: Stadskontoret)

c. The City of Malmö On-Call Social Services Division (Sw: Social Jour)

4. Voluntary network. This network brought civil society organisations into dialogue with the municipal coordinators at the Social Service Administration. The Swedish Church and City Mission participated in these meetings. The volunteer network Solidarity with EU Migrants, which provided hands-on support to the squatters of the Sorgenfri camp, was invited but chose not to participate.

Notably, the Municipal Coordinators started in their roles just as the City of Malmö Environmental Administration began its attempts to have the Sorgenfri camp demolished, and against the backdrop of intense public and political debates about the country-wide settlement crisis. Locally, the expected demolition of both the Sorgenfri camp and the tent encampment in Pildammsparken added a sense of urgency to their tasks. The political leadership of the City of Malmö wanted to formulate a policy on resettlement and develop a strategy to prevent the establishment of another large settlement before either of the tent encampments in question were demolished. Thus, the coordinators were asked to prioritise the 'settlement question' before addressing the other above-listed focus areas. Soon, the Head of the Unit for Safety and Security also stepped in and took over the responsibility for devising a strategy on unauthorised settlements. The Municipal Coordinators continued to oversee the development of policies on social service provision (joint interview with the Social Worker/Municipal Coordinator and the Head of the Unit for Safety and Security, September 7, 2015). Consequently, the overall question of 'vulnerable EU citizens' was effectively split between two separate administrations, operating under two quite different mandates; consequently, the question of settlements came to be divorced from a 
social-work and humanitarian agenda and assimilated, instead, into one of public order and security. ${ }^{94}$

As a further result of this, a two-pronged approach developed. On the one hand, the local authorities would step up their efforts to enact a kind of zero-tolerance approach to unauthorised settlements. On the other hand, the municipality would supply funding for certain services to be provided to the population in question via faith-based Civil Society Organisations (CSOs) like the City Mission.

\section{The Municipal Strategy on Unauthorised Settlements}

The aforementionedsettlement network, now with the Head of the Unit for Safety and Security at the helm, came to function as a forum where representatives from the municipality and the police met and devised a joint strategy for preventing the future establishment of large settlements like Sorgenfri camp. The network was tasked with assessing three alternative strategies on unauthorised settlements, but from what I have learnt, they only seriously considered one of them - a zero-tolerance approach, modelled on a strategy that had been developed by the local authorities in Göteborg to facilitate 'early removals' (Sw: tidiga avhysningar eller avlägsnanden). The other two options - a passive laissez faire approach, and a strategy based on the public provision of an authorised campsite - were both written off as being unrealistic and untenable in the long run.

During the years 2014-2015, several Swedish municipalities were actively experimenting with providing authorised campsites. For example, the nearby city of Helsingborg kept a campsite open for 'vulnerable EU citizens' and other homeless individuals throughout the winter of 2014/2015. The city of Lund, a ten-minute train ride from

\footnotetext{
${ }^{94}$ In an evaluation, which they wrote in 2016 as their assignment was coming to end, the municipal coordinators describe that they had intended to take a more comprehensive approach towards the settlement issue (and the broader question of homelessness among EU citizens), but the urgency of the situation in the early spring of 2015 meant that the immediate problem of how to prevent new settlements from being established was given priority before other more social-work oriented perspectives.
} 
Malmö, also subsidised a caravan site. As I discuss in chapter four, the squatters and their allies also lobbied the city for such a resolution. At that point in time, in the early spring of 2015 , none of the locally represented political parties, apart from Sverigedemokraterna, had an official standpoint with regards to the unauthorised settlements of vulnerable EU citizens. A representative of the green party, Miljöpartiet, Karolina Skog, stated that her party favoured a strategy of resettlement but that they did not know exactly how to proceed with this (see Häggström, 2015). The left party, Vänsterpartiet, took a similar position, insisting on the need for a resettlement plan to be put into place before any evictions were carried out. The liberal party representative Ewa Bertz proposed that the municipality should provide temporary housing, using a type of sheds that had been left over from the election campaign half-a-year earlier (quoted in Häggström, 2015). Her party, Liberalerna (then Folkpartiet), had previously been critical of the municipal government for failing to do more to alleviate the difficult situation of homeless EU citizens. However, none of these suggestions were endorsed by the Social Democrats - the largest party in the City Council.

As it was explained to me, the Social Democratic political leadership and majority in City Council was clear on the fact that they were not going to officially authorise and provide funding for an alternative campsite. Hence, the other two strategies were dismissed. The following is an extended set of quotes from an interview I did with one of the municipal coordinators and the head of the Unit for Safety and Security in the spring of 2016, the first being from the municipal coordinator:

You are asking us why the City of Malmö has chosen a different strategy than Helsingborg [which did provide a publicly funded campsite for some time]? Well, I can't say that there has been much discussion about it. It was very clear from the beginning, we do not want to offer this. So, we choose to look at it but it was more to see what options are available, it is not something that we have continued to look at because the directions from the politicians were clear. And ultimately it has to be a political decision if we are going to provide a piece of land.

The Head of the Unit for Safety and Security chimed in: 
It is also difficult from a legal point of view. The solution they have in Helsingborg and Lund are not really correct according to the letter of the law, quite simply because it is not consistent with the principle of legal equality. And even if you do provide land, it is required that the operation complies with the regulations set out in the Environmental Code, and the Civil Protection Act, and the Planning and Building Act and all these different frameworks. And then we will have created a new category of housing. And then the question becomes, should we provide housing for EU citizens? So, then we are directly back to the big question. You see, there are so many unresolved issues here so a decision like that has not even really been on the agenda here. Also, the national coordinator [i.e., Martin Valfridsson] is basically saying that municipalities should follow existing laws and then the situation will resolve itself.

In the end, the City Council approved an Action Plan that outlined a much less ambitious plan for resettlement than what had originally been proposed by both Miljöpartiet and Vänsterpartiet. Instead of an alternative campsite, the Council voted to provide future evictees with emergency accommodation for a maximum of five nights. They also agreed to sponsor 40 shelter beds specifically designated for 'vulnerable EU citizens' for the winter months.

\section{Local Policies and Initiatives to Provide Shelter and Services}

The Action Plan served to further formalise a model that had developed over the year 2014, according to which support for "vulnerable EU citizens' is organised through public-private partnerships with Christian charities. This reliance on the civil society sector is in itself nothing new: There is a fairly longstanding tradition in many Swedish municipalities, including Malmö, of organising homelessness services through hybrid institutions and partnerships between the public sector and CSOs (Arvidson, Johansson, Johansson, \& Nordfeldt, 2018; Nordfeldt, 1999). Already in November 2014, the City Council voted to increase the funding to the City Mission to enable the organisation to open a designated service centre for 'vulnerable EU citizens' (Mamö Stad Kommunfullmäktige, 2014, November). The centre, named Crossroads, was modelled on similar already existing meeting places in Stockholm 
and Göteborg. It officially opened its doors in January 2015, remains operative today in 2019. Crossroads is open seven-days a week, and it provides daily free breakfasts and access to showers and laundry facilities. Several staff members speak Romanian and can provide advisory services. There is also a nurse available on site a couple of days a week.

During the winter of 2014/2015, the City of Malmö also opened the first overnight facility specifically geared towards street-homeless EU citizens. In previous years, the municipality had not provided any such facilities as it was assumed that most EU citizens would return home during the winter months (Paulsson, 2015) . However, as it drew closer to winter that year, the Social Services Committee decided they would provide an emergency shelter to stay open in the case of 'extreme weather'. The decision provides an interesting case study of biopower in action: It defined in great detail, down to the exact degree of temperature, when the emergency shelter should be opened versus when it should be closed. 'Extreme weather' was defined on the basis of the Swedish Metrological and Hydrological Institute (SMHI)'s classificatory system as 'warning class 2' (very severe weather) or temperatures below minus five degrees Celsius $\left(-5^{\circ} \mathrm{C}\right)$. Later the Social Services Committee revised their decision, opting instead to set up an overnight facility to stay open throughout the 'metrological winter', defined by SMHI as a period of at least five consecutive days with average temperatures below zero degrees. With this definition, winter was predicted to start sometime in early January. However, it arrived already on Christmas day (December 25, 2014), when most municipal politicians and staff were on holiday. At this point, they still had not found an appropriate space to host the overnight meeting place. Hence, it was decided that Crossroads would stay open around the clock during the week between Christmas and New Year's Eve.

At the beginning of the new year, on January 2, 2015, the overnight facility was moved to Sofielunds Folkets Hus, about a kilometre from the Sorgenfri camp. The space, which normally operates as a community centre, was seen by many to be ill-equipped to meet the needs of its new 
clientele. Furthermore, the building was not set up to function as a shelter: there were no beds and barely any comfortable chairs to rest in, and the fire regulations did not permit people to sleep there. Nevertheless, the space quickly became overcrowded to the point that it could not quite fit all the people who needed a place to warm themselves at night. The municipality had expected that some 30 people would show up to use the overnight facilities. Instead, over 100 people came (see Paulsson, 2015). A week after the facility opened its doors, reports surfaced that some of the staff had made some of the visitors sleep in the basement of the building, where there was no proper ventilation and no emergency exits (see Forsell, 2015). Shortly thereafter, instructions were issued that people were not allowed to sleep at the shelter. This upset some of the visitors, who staged a demonstration for the right to sleep with banners that read 'we just want to sleep' (Sw: vi vill bara sova). Towards the end of February, when the metrological winter was officially over, the overnight facility at Sofielunds Folkets Hus closed its doors, and many of the squatters from the Sorgenfri camp who had stayed there throughout the winter months returned to the settlement.

Following the winter of 2014/2015, the Social Services Committee formalised a policy on shelter provision. This was approved along with the overall Action Plan on Vulnerable EU Citizens at a City Council meeting on March 25, 2015. It was decided that the municipality would finance a shelter with a total of 40 beds to be open for a total of three months during winter. The municipality signed a contract with the local Pentecostal Church (Malmö pingstförsamling/Europaporten) to run the shelter. The shelter opened its doors for the first time in December 2015, and it has been open three months a year for the last four years (20152018). It is located on the church premises and consists of a group of portable housing units. Access to the shelter is (theoretically) determined on the basis of need; individuals apply at Crossroads, and priority is supposed to be given to elderly and sick individuals as well as to pregnant women. 


\section{Undoing the Geographies of Survival}

In this final part of the chapter, I shift focus from questions of (legal) rights and policy to describe how the evolving practices of the municipal authorities (especially in the aftermath of the demolition of the Sorgenfri camp) have had the effect of gradually and cumulatively undoing what I am calling here the geographies of survival for 'vulnerable EU citizens'. I argue that the situation of 'vulnerable EU citizens' is not simply a question about formal rights and access to services but about access to space in a very concrete sense. Here, it is useful to recall Waldron's (1991) truism that 'everything that is done has to be done somewhere' and therefore, in order to be, one must have a place/space to be. My claim is that the local authorities in Malmö, along with the local police, have adopted a repertoire of tactics that function to restrict how homeless, poor, and otherwise marginalised EU citizens are able to access and use urban space for securing shelter. In what follows, I account for the different elements of this repertoire.

\section{'Careful offensive': The Action Plan in Practice}

In May 2015, it was reported that the police in Malmö would be intensifying their efforts to do away with, and prevent any future establishment of, settlements within the city through increasing surveillance and enforcement of public order ordinances. A high-ranking police officer in Malmö called this 'a careful offensive to ensure that new camps do not emerge' (quoted in Satz, 2015). The City of Malmö has also intensified their collaboration with the police in this area. This is the municipality's strategy towards unauthorised settlements put into practice. While spending time with some of the people who are targeted by these practices, I have heard many stories of how the police attempt to move on people who sleep outside at night. These practices have been ongoing since at least 2015, and their cumulative effect is to make it very difficult for those who live rough to find places to rest. As I discussed in the previous chapter, these 'early evictions' rely on the use of highly discretionary police powers, and they give squatters few, if any, opportunities to contest their removal. 


\section{Closing Down Volunteer Shelters}

Concurrent with the demolition of the Sorgenfri camp, two separate voluntarily run (i.e., non-publicly funded) spaces opened where 'vulnerable EU citizens' were able to spend the night. The church, Johanneskyrkan, opened their doors for refugee migrants who were transiting through the city and decided to allow homeless EU citizens to stay there as well. The set up was very simple. The church kept open during the night and people were allowed to sleep on or in between the wooden pews. Similarly, the anarchist social and culture centre, Kontrapunkt, which organised against the demolition of the Sorgenfri camp, provided a 'semi-secret' shelter for the evacuees. The centre had originally set up a shelter for transit refugees, but when the Sorgenfri camp was demolished and the border was closed for migrants, they decided to make it available for the evacuees.

In the early spring of 2016, the City of Malmö Planning Department issued injunctions with heavy fines to both organisations (the Church and Kontrapunkt) for operating shelters without the requisite building permits, and both shelters were therefore forced to close. Notably, the fees were unusually high in both cases. For example, Kontrapunkt risked a fine of 612,134 SEK. As a consequence, the church decided to close down their night service and has not re-opened it again. Kontrapunkt closed down their shelter in the spring of 2016 but decided to re-open not as a shelter but as an open overnight facility (i.e., without beds, Sw: värmestuga) for people to spend the night the following winter (2016/2017). The organisation was later caught up in a complicated legal battle with their landlord. From what I understand, the conflict was triggered by a different issue (the landlord did not approve of an antigentrification statement that the centre made), but the landlord was able to use the building-permit issue as a lever to put pressure on the group. Kontrapunkt has since relocated their overnight facility to a different space and collaborates with a number of CSOs to keep it open during the winter months. 


\section{Limiting Protest}

On two occasions - following the demolition of the Sorgenfri camp, and again following the closing of the two volunteer shelters - the community from the Sorgenfri camp organised sleep-in protests outside the City Hall (Sw: Stadshuset). Both times, they had their matrasses, blankets, and other belongings confiscated by the police, who claimed that they were in violation of the Public Order Act (specifically for 'cluttering' public space). The second time, they were also prevented from sleeping on the site with reference to a police decision that stated sleeping was not a legitimate form of protests and therefore not protected by freedom of speech. The decision was challenged in court, and the court ruled in favour of the police (The Administrative Court of Appeal in Göteborg judgement in case no. 130-17).

\section{Fining People for Sleeping in Cars}

As the authorities intensified their efforts to move on homeless EU citizens who sleep rough, many of them purchased cars, often old and beaten-up ones, which they used to sleep in. As a response, the authorities started targeting people who sleep in their cars (Ingvarson, 2016). Moreover, private parking companies began to impose fines on people who are found sleeping in their cars, even if they have paid the parking ticket (interview with solidarity activist 2, March 17, 2017). The Municipal Chief Executive of Security announced in late 2016 that their department would look into the possibility of amending the local order ordinances to prohibit people from sleeping in their cars (Ingvarson, 2016). Meanwhile, many parking companies do not accept cash payments, making it difficult for people without bankcards to park anywhere in the city without risking hefty fees.

\section{A Changing Landscape}

It is not just the municipal authorities that are driving these changes. Private and semi-private actors are also contributing to reshaping and reorganising the geographies of survival for 'vulnerable EU citizens'. For 
example, the government-owned company Jernhusen $A B$, which owns and manages railway stations across the country, has attempted to limit access to waiting halls to ticket holders only in an explicit attempt to keep out beggars (Berglund, 2014; Jansson, 2014). The grocery store ICA at Södra Förstadsgatan used to have lockers that were frequently used by homeless EU citizens (and others) to store valuables, medicines, ID-cards, and the like. In the summer of 2015, they removed the lockers without warning with the result that several people lost important documents and medicines (Omar, 2015). Another local example is the shopping mall Triangeln, where there used to be an open space that served as a gathering spot for homeless EU citizens where they would go to hide out from the elements. At one point, in early 2016, this space was transformed into a seating area for the adjacent crêpe café, with restricted access 'for patrons only'. The adjacent McDonald restaurant also stopped accepting cash payments after a certain hour, presumably to prevent people without bank cards from coming there to charge their phones, use the bathroom, and warm up while buying coffee or fries.

\section{Concluding Remarks}

In this chapter, I have discussed the situation of 'vulnerable EU citizens' in Malmö in terms of their access to municipally provided social assistance and services and their opportunities to access and use public space. In the first part, I discussed the practice of providing emergency social assistance primarily in the form of a bus ticket to their home countries. I argued that this is practice reveals not only the limited rights of EU citizens to access social assistance in another member states but also the in-betweenness and undecidability of the category of the 'vulnerable EU citizen': They are neither recognised as irregular migrants nor effectively treated as full citizens. In the second part, I charted the development of local policies and programmes for 'vulnerable EU citizens' in the city. The overall policy approach of the City of Malmö is marked by a duality. On the one hand, the city sponsors certain services, including a winter-time shelter, for the group. On the other hand, the authorities have intensified their efforts to do away with unauthorised settlements of 'vulnerable EU citizens' and with other spaces and places 
that the community uses. Finally, in the third part, I outlined the repertoire of tactics that function to gradually and cumulatively undo the geographies of survival for the group in question. In the next and final chapter, I will discuss the implications of this. 


\section{FREE TO MOVE ALONG}

As I am preparing to submit this thesis, in the late summer of 2019, one Swedish municipality after another are announcing their intentions to adopt anti-begging regulations. Vellinge, a wealthy suburban municipality neighbouring Malmö, was the first to introduce a set of order ordinances outlawing 'passive money collection' in certain designated areas of the town. The 'begging ban' first bounced through the court system for about a year and a half, but once the Supreme Administrative Court gave it a green light in December 2018, two other municipalities (Staffanstorp and Katrineholm) soon followed suit. And in July, 2019, the town of Eskilstuna introduced a 'begging permit', requiring anyone who 'passively' asks for money in the street to pay 250 SEK upfront for a licence (Henley, 2019). Another ten municipalities are currently considering some form of begging ban. Crucially, these experiments in local-level law-making and enforcement comes after years of debate over whether or not begging should be banned at the national level. It is widely understood that these prohibitions are aimed at, and will primarily affect, 'vulnerable EU citizens'. Therefore, this seems to me a pertinent moment to return to some of the questions I posed at the outset of this thesis.

Nation state borders have undergone major transformations over the past few decades, including in the form of a simultaneous externalisation and internalisation of immigration control policies and practices. In this context, cities have emerged as ever more important spaces for the exclusionary control of people on the move. In the lead-up to the 2004 'Big Bang' Eastward Enlargement of the EU, the French philosopher Étienne Balibar $(2004,2009 b)$ hypothesised that the project of European unification would be paralleled by the emergence of a system of 'European Apartheid', characterised by a hardening of the external borders and a re-duplication of these borders in the form of internal and 
distinctly urban bordering practices targeting Europe's racialised Others, including the Roma. In this thesis, I have sought to elaborate on this hypothesis, and to explore the mechanisms, effects, and implications of urbanised mobility controls. Committed to the idea of 'studying up' (Nader, 1969), I set out to analyse how the authorities in Malmö, Sweden's third largest city, have responded to the presence and situation of street-homeless 'vulnerable EU citizens', the majority of whom are thought to be Roma from Romania. I took as my starting point the observation that 'vulnerable EU citizens' have been pervasively problematised as unwanted migrants, and I asked how the City of Malmö and other local-level authorities (e.g., the police) have acted to discourage and otherwise manage the mobilities of a category of people who have a formal right to move within the territory of the EU member states but whose mobilities are nevertheless deemed excessive and problematic.

The study was organised as a case study, centring on the intensely contested Sorgenfri camp - a makeshift squatter settlement of some 200 Roma-identified EU citizens from Romania. The settlement was established in the spring of 2014 and lasted for a year and a half before it was eventually demolished on the order of the City of Malmö Environmental Committee on November 3, 2015. In the interim, it became a locus of much controversy and a salient symbol of the broader 'question of vulnerable EU citizens'. As a 'critical case' (Flyvbjerg, 2006), it offered me a productive vantage point from which to trace the development of policy and government practices towards the group in question and to observe how the authorities negotiate the legal ambiguities, moral-political dilemmas, and social conflicts that swirl around the unauthorised settlements of 'vulnerable EU citizens'. The analysis was carried out with a theoretical framework informed by Foucaultian governmentality studies and theories of scale, combining insights from the field of critical border and migration studies with concepts from the legal geographic literature on urban socio-spatial control. In particular, I followed Valverde's (2010) call to foreground the role of scalar categorisation and politics in the networked policing of various non-citizens, and I drew on the work she and others have done on 
the urban as the pre-eminent scale of discretionary and flexible forms of 'police power' (Blomley, 2013; Levi, 2008; Neocleous, 2000). I also made use of the notion of a 'geography of survival' (Mitchell \& Heynen, 2009) to theorise the mechanisms and effects of government interventions that restrict access to both private and public space for 'vulnerable EU citizens'.

In this final chapter, I will summarise my main findings, discuss their implications, and further elaborate on my conceptual argument regarding the urbanisation of mobility controls in Europe. I will also offer brief reflections on my research process and suggest future research directions.

\section{'EU Citizens Are Welcome, but Swedish Legislation Will Apply'}

In contemporary Swedish public and policy debate, 'the question of vulnerable EU citizens' is typically indexed as a problem of them being here, where here is sometimes a specific site or a city but more often the country or 'the nation' as a whole. They are pervasively problematised as unwanted migrants. As several others before me have argued, this reflects a discourse of welfare nationalism. 'Vulnerable EU citizens' are widely perceived as a (potential) burden on the Swedish welfare state, and their presence is seen to disrupt the (self-)image of Sweden as a country that once and for all eradicated extreme poverty and its various manifestations (see Bäckström et al., 2016; Hansson, 2019; Hansson \& Persdotter, 2019). By the same token, it is often said that the only possible long-term solution to the various problems facing the group (poverty, marginalisation, etc.) necessarily needs to take place in their homecountries (cf. Lind \& Persdotter, 2017). In turn, this discourse shapes what solutions become thinkable: because the question of vulnerable EU citizens is defined largely as a question of their problematic or even illegitimate presence, return or repatriation appears as the reasonable and sound solution.

My analysis of the controversies surrounding the Sorgenfri camp showed that there is a constant scalar interplay between the problematisation of 
'vulnerable EU citizens' as unwanted immigrants to the country and more local concerns regarding their behaviours and whereabouts in specific places. For example, complaints by private citizens regarding the settlement would often relate concerns over concrete nuisances (e.g., littering, open defecation, and smoke emissions) to wider symbolic orders - particularly those of the nation. The apparently disorderly and unsanitary conditions in the settlement were thus repeatedly attributed to the squatters themselves as proof of their foreign and unruly ways and taken as a threat to ostensibly 'Swedish' norms of lawfulness, order, and sanitation. Similarly, a series of connections were drawn between the illegality of the settlement and the squatters' supposedly illegitimate presence in the country. The 'nuisance talk' (Ghertner, 2012) that circulated in the private complaints about the Sorgenfri camp (and beyond) was also racialised in particular ways: it echoed the longstanding negative stereotype of the 'dirty Gypsy'.

Admittedly, the complaints in questions were especially crude. As I have emphasised, representatives of the City of Malmö's red-green city government did not speak of the squatters of the Sorgenfri camp as culprits or in overtly antipathetic or racialising terms. Instead, they isolated the Sorgenfri camp (as a spatial object) as a nuisance and sanitation hazard for the squatters. Consequently, this allowed them to rationalise the ultimate evacuation and demolition of the settlement as a necessary means to protect the squatters against harm; ensure equality of treatment under environmental law; and uphold established standards of sanitation, health, and safety for the benefit of the public at large. The undeniable paradox of the decision was that although it was expressly justified as a means to make sure that 'everyone should have access to good, dignified housing', it left the squatters in an even more radically precarious situation, on the streets with no reliable access to shelter. On this point, my findings resonate with existing scholarship, which contends that the representation of Roma camps (and by extension, Roma-camp dwellers) as dirty, disorderly, and delinquent is a key component of the contemporary security discourse about Roma in Europe - one that contributes to reinforcing the conditions of Roma evictability (see 
Aradau, 2015; Clough Marinaro, 2014b; Hepworth, 2012; van Baar, 2017c). My case study specifically illustrates how, in the Swedish context, 'vulnerable EU citizens' are rendered evictable in the name of humanitarian and benevolent care and protection (cf. Barker, 2017).

As I have argued, the case of the Sorgenfri camp is exemplary of a dominant representation of the settlements of 'vulnerable EU citizens' (and by extension, their inhabitants) as a public order and sanitation issue. This problem representation is thus a key element of what I am calling the urbanisation of mobility controls - the more or less strategic rescaling of mobility control practices to the urban scale. One of the most succinct and explicit expressions of such a scalar shift is found in the 2016 report of the then National Coordinator for Vulnerable EU Citizens, Martin Valfridsson. I cited this passage already in the introductory chapter, but I choose to include it here again as it so clearly illustrates the slide from the register of immigration policy to that of urban law:

Sweden's message should be clear. EU citizens are welcome here, but Swedish legislation will apply. Living in parks, other public spaces or on private land is prohibited. The same applies to littering and to relieving oneself in public. (SOU 2016:6, p. 15)

As I have argued, this slide can usefully be conceptualised in terms of a 'game of scale' (Valverde, 2009a, 2010). Unable to enact restrictions on the entry of 'vulnerable EU citizens', but nevertheless intent on 'reducing vulnerability and beggary', the national government shifts scales to encourage police and public officials to clamp down on minor offences (like squatting and defecating in the open) and to mobilise a host of measures to control how 'vulnerable EU citizens' are able to access and use urban space for securing shelter and livelihoods. This crucially involves a shift from controlling conditions of entry and exit to micromanaging conditions of stay. Formal border controls are substituted by a complex and diffuse set of practices enacted at a local and distinctively urban scale. Already in the summer of 2015, before the coordinator's report was released, the national red-green coalition government proposed to simplify the removal of unauthorised settlements as a direct means to 'combat vulnerability and beggary' and stem the 
influx of 'vulnerable EU citizens' to the country. Later, the National Coordinator, Martin Valfridsson, recommended that municipalities refrain from providing alternative (authorised) campsites and restrict access to education and social services so as to minimise 'pull factors' that might attract EU citizens from less affluent member states to Sweden (see also Lind \& Persdotter, 2017).

The urbanisation of mobility controls does not just involve the top-down devolution of authority and responsibility from the national to the local levels of government and law enforcement. Local-level governments and authorities are also autonomously enacting policies and programs that whether by design or default - serve to keep out unwanted groups. My analysis showed that the authorities in Malmö have responded to the presence and situation of 'vulnerable EU citizens' in the city by enacting a series of practices and programs that jointly add up to an indirect policy of exclusionary mobility control. These include the systematic removal (Sw: avlägsnande) of unauthorised settlements and the targeted elimination of other significant spaces of shelter. The 'evacuation' of the Sorgenfri camp left some 200 individuals (more than half of the city's estimated total population of 'vulnerable EU citizens') on the street with only minimal access to alternative accommodation. The squatters made repeated claims to be re-settled on an alternative (officially authorised) campsite, but although there was some support for this idea among the political parties on City Council, they ultimately voted on a plan to provide access to shelter only during the winter months and for a limited number of people. In the lead-up to the demolition of the Sorgenfri camp - and in an explicit effort to prevent the emergence of another large and difficult-to-evict settlement - the local authorities also implemented a zero-tolerance approach towards unauthorised settlements. The approach relied, and continues to rely, on the discretionary use of public order ordinances and police law to achieve the early and swift removal of makeshift encampments. Its effect is to create a situation where homeless EU citizens are routinely made to 'move along' in a seemingly endless cycle of exclusion. In the months following the demolition of the Sorgenfri camp, the local authorities (specifically the Planning 
Department) also forced the closure of the two volunteer-run shelters that had provided roofs over the heads of many 'vulnerable EU citizens', including the former residents of the Sorgenfri camp. The exclusionary effects of these practices are further compounded by the fact that many private, commercial actors attempt to keep 'vulnerable EU citizens' and other street-homeless people off their premises.

Altogether, the cumulative effect of these practices, irrespective of the immediate intention behind them, is the elimination of the geographies of survival of 'vulnerable EU citizens' - the legal and social geographies that make it possible for them to inhabit and make a life in the city. With almost no access to regular accommodation or other places to legally and safely carry out elementary human activities (like eating, cooking, sleeping, or just resting), residing in the city becomes difficult or even unbearable. This is the familiar core mechanism of hostile environmenttype policies: They operate indirectly and diffusely to encourage what KSue Park (2019) calls 'self-deportation', and they do so by targeting different aspects of people's everyday lives.

In this context, it is worth recalling Waldron's (1991) argument about the connection between the freedom to do something and the freedom to be somewhere: "no one is free to perform an action unless there is somewhere [they] are free to perform it' (p. 296). Accordingly, someone who is not free to be in any place is 'comprehensively unfree'. By eliminating the geographies of survival for 'vulnerable EU citizens', the authorities are effectively undermining their putative right to freedom of movement. The result is to reinforce what Yildız and De Genova (2017) refer to as the 'complex modulations of un/free mobility' in the EU (p. 12). Destitute EU citizens who are formally free to move and reside within the union are repeatedly moved along, thus effectively prevented from settling.

\section{Mechanisms and Implications of Control}

Crucially, the urbanisation of mobility controls involves a qualitative change in how bordering is done. It fuses cross-border mobility management with urban law and governmentalities. As Valverde (2005, 
2009a) and others convincingly argue, and as I have attempted to show through my case study, urban law (e.g., nuisance and public order law) differs in several key respects from higher-order law, especially rights law. Urban law micromanages activities in and uses of both public and private space in ways that impact people's abilities to inhabit the city, often with disproportionate effects on street-homeless and other marginalised populations. However, it mostly avoids governing through categories of person. Unlike the vagrancy laws of the early modern era, which made it a punishable offense to be a vagrant (i.e., criminalising a status), contemporary anti-homeless ordinances tend to be facially neutral: They generally rely on broad-ranging, flexible, police-type regulations that aim to order urban space and that technically apply equally to all who inhabit such spaces. The zero-tolerance approach towards the unauthorised settlements of 'vulnerable EU citizens' in Malmö and elsewhere in Sweden, tellingly, did not (and still, does not) rely on exceptional measures but on the ordinary and discretionary powers of the police to intervene against and remove people who are deemed to be disturbing public order or violating some other order ordinance (e.g., defecating in the open or littering). As a modality of control, the zero-tolerance approach is thoroughly embedded in the everyday lives of those it targets. It is also dependent on the decentralised and discretionary decision-making on numerous patrolling officers, rather than on the commands of a single sovereign. And even if it disproportionately affects 'vulnerable EU citizens', it is inordinately difficult - not to say impossible - to prove discriminatory intent at the level of discrete removal acts.

The specific case of the Sorgenfri camp serves, again, as a key example of how the 'question of vulnerable EU citizens' is framed and treated as an environmental nuisance and sanitation problem. As such, it illustrates some of the effects and implications of a 'game of scale'. Nuisance law is one of the paradigmatic examples of urban law. As a symbolic and intrinsically intersubjective category, nuisance expresses norms of cleanliness and propriety. This is, in essence, what allowed the demolition of the Sorgenfri camp to be read as a positive intervention and a necessary 
means to care for the well-being of the squatters and the public at large. At the same time, as a legal category, 'nuisance' regulates property in a site-specific manner. From this follows that nuisance governance tends to localise both problems and solutions. The settlement as a nuisance came to be read as a discrete and spatially-bound environmental problem rather than the effect of a complex of social relations of impoverishment and marginalisation.

Furthermore, there is something to be said about the features of nuisance governance and how it worked, in the specific case of the Sorgenfri camp, to re-work the terrain of struggle for the squatters and their advocates who opposed the evacuation and demolition. As I explained, the choice to evacuate and demolish the settlement on the basis of environmental law (specifically the mechanism of 'correction') served as a means to circumvent certain due process protections, which would have allowed the squatters legal standing to appeal or otherwise challenge their removal. This had further implications. Nuisance regulations, much like other forms of urban law, operate through categories of activity, use, space, and property rather than through categories of person. As a result, such regulations tend to effectively block or deflect rights-based arguments. This is, in short, what happened in the case of the Sorgenfri camp. In technical-legal terms, the ultimate decision to evacuate the settlement was a decision to restore the environmental conditions on the site. It categorised the settlement as an object as a nuisance and denied any claims the squatters' might have had to the site. This served to effectively deflect the squatters' claim to not be evicted without also being re-settled somewhere else, a claim that was couched in a language of human and minority rights.

The demolition of the Sorgenfri camp and the zero-tolerance approach to unauthorised settlements assumes their significance as exclusionary bordering practices only in the context of a set of overlapping and mutually reinforcing mechanisms that extend beyond the urban scale. For those impoverished and unwaged individuals who are deemed to be a 'burden on the social assistance system' of another member state, EU citizenship comes with a right to move without a corresponding right of 
residency. As Yildiz and De Genova (2017) note, it does not offer a perfect 'free-for all of rights to mobility' (p. 12), but it is also not a completely restrictive regime. Indeed, the 'complex modulations of un/free mobility' in the EU creates a grey legal area where destitute EU citizens can, in practice, remain living in another member state for years with an ambiguous residency status and minimal or no welfare entitlements. This marginality is further compounded by the fact that the national and municipal social rights orders are also exclusionary, limiting rights to various social services to regularised residents only. As I discussed in chapter seven, 'vulnerable EU citizens' occupy a curious status position: They are neither recognised as irregular migrants nor effectively treated as full citizens. They are frequently excluded both from accessing various social services that are available to citizens and from certain rights that have been codified in law as belonging to 'individuals who reside in the country without permission' like rejected asylumseekers and other irregular migrants (cf. Lind \& Persdotter, 2017).

The presence and situation of destitute EU citizens typically becomes a problem for local government before it becomes a problem for the national government. To some extent, the urbanisation of mobility controls comes about as the default effect of this. But it is also, as I have noted, the outcome of a strategic 'games of scale'. The first National Coordinator for Vulnerable EU Citizens, Martin Valfridsson, instructed local authorities to clamp down on unauthorised settlements, intensify the policing of rough sleepers, and restrict access to social services to 'vulnerable EU citizens'. By actively renouncing any responsibility to integrate and provide services to the population in question, the national government has also effectively shifted responsibility onto the local level authorities, leaving often cash-strapped municipal governments in a position of having to address the various issues associated with 'vulnerable EU citizens' with whatever means and regulatory tools they have at their disposal.

The policy discourse on the 'question of vulnerable EU citizens' in Sweden has revolved (and continues to revolve) around the principle of legal equality. Many restrictive and exclusionary interventions, like the 
demolition of the Sorgenfri camp, have been justified with reference to this principle. Of course, the paradox is that 'vulnerable EU citizens' have very few positive social rights. In practice, then, equal treatment means that they continue to be excluded from a range of welfare entitlements that are, at least in theory, available to nationals. At the same time, they remain subjected to the same negative duties and prohibitions that apply to others. In a context of differentiated and uneven (positive) rights, equal treatment amounts to very unequal outcomes.

The social policies of the City of Malmö towards 'vulnerable EU citizens' are not only exclusionary but also rather contradictory. The sphere of local-level service provision appears as one where the boundaries and contents of citizenship as negotiated. In chapter seven, I discussed the established practice of providing emergency social assistance to vulnerable EU citizens mainly in the form of a subsidised return trip to their countries of origin. As I argued, this practice functions as a technology of 'voluntary' repatriation. However, the underlying logic is not exactly one of cross-border immigration control. When it comes to this specific practice, the municipality's treatment of 'vulnerable EU citizens' is consistent with how they treat homeless or otherwise transient non-resident Swedish citizens who seek emergency assistance: They send them back to their municipality of residence. The key difference is that while the latter is transported to another municipality, where they would typically have access to more substantial forms of support, the former is repatriated to another country altogether. Thus, this serves as another example of how the mechanisms and underlying rationalities of urban mobility controls are different from those of national level immigration policy. It also goes some way to show the inherent instability of the common binary division between citizens and non-citizens and the ways in which exclusions from without are interconnected to exclusions from within.

On the other hand, the municipality has funded, and continues to fund, some elementary services to 'vulnerable EU citizens', mainly through partnerships with the civil society sector. The city funds a winter shelter designated for 'vulnerable EU citizens' and helps finance the service 
centre Crossroads. If these are marginal and precarious forms of social service, organised outside the established system of welfare provisions, they nevertheless serve as a reminder that social policy at the municipal level can both be more exclusionary and more inclusionary than national level policy. It also tell us something about the discretionary capacity and pragmatic quality of local level government. Or at least, that would be my interpretation. Indeed, if the distinction between citizens and non-citizens are clear-cut in law and theory, such distinctions (and the exclusions they entail) are frequently untenable at the embodied and lived scale of the city. Despite the overall exclusionary character of the municipality's various practices towards 'vulnerable EU citizens', people continue to come and stay in the city. They continue to assert their presence and make claims of 'being here' (Bosniak, 2007). The city, which is an arena for exclusionary bordering practices, is also always at the same time a space where such exclusions are contested and re-negotiated.

\section{Conceptualising the Urbanisation of Mobility Controls}

My analysis and argument regarding the urbanisation of mobility controls is indebted to previous scholarship on internalised, everyday, biopolitical, and racialised bordering practices in present-day Europe and beyond. I have attempted to make a contribution to this continuously growing field of research by bringing in insights and theories from the legal geographic literature on urban socio-spatial control. I hope to have demonstrated that this can be a useful strategy to understand the precise mechanisms, effects, and implications of the fusing of mobility governance with urban law and governmentalities.

To briefly recap my conceptual argument, I have defined the urbanisation of mobility controls as rescaling of mobility control practices to the urban scale. Such a rescaling can take the form of a strategic top-down devolution of powers from the national to the local level, or it can be the result of autonomous and discretionary bottom-up 'policy activism' (Varsanyi, 2010b) on the part of local level governments and other urban actors. Urban mobility control policy also does not need to be exclusionary. If it relies on the scalar differentiation of powers between 
the city and the state, this differentiation of powers can also be used to adopt measures that run in the opposite direction, towards extending services and protections to variously irregularised migrants. Sanctuary city ordinances are a case in point.

As I have argued, the overall government response to 'vulnerable EU citizens' is indicative of a convergence between mobility control and urban socio-spatial control, or a rescaling of mobility control from the edges of the nation-state to the urban scale and, ultimately, to the body of the migrant subject. Indeed, the cumulative effects of the current control practices targeted at 'vulnerable EU citizens' in Malmö, Sweden - in particular, the repeated evictions of their tent encampments and settlements - is the elimination of their geographies of survival. As I have argued, this mirrors the 'hostile environment' and self-deportation-type policies that are being enacted against variously irregularised migrants in many parts of the world today. There is also a strong historical precedent for these kinds of practices in the Swedish context. In particular, there are significant similarities between the treatment of 'vulnerable EU citizens' today and the exclusionary controls targeted at Roma and Travellers communities throughout the early 20th century.

There is a tension in my argument concerning questions of intent. On the one hand, I have argued that the urbanisation of mobility controls involves a more or less strategic shift from one scale of governance to another. This implies a measure of intent. On the other hand, it is also the consequent outcome of the aggregate actions and ad hoc decisions of a multitude of different agents inside and outside the municipality, each of whom are acting within their specific spheres of authority and responsibility to achieve certain proximate goals. I want to emphasise that I do not assume the elimination of the geographies of survival for 'vulnerable EU citizens' to be guided by a singular and coherent government agenda of exclusionary mobility control. There is no one master plan. It is widely recognised in the literature on the diffusion of mobility controls inside state territory that they enrol a variety of actors and attach themselves to diverse government rationalities. Because they always rely on indirect measures, it is often difficult to trace their exact 
mechanism and establish ascertain the relationship between the purpose behind a given practice and its effects. Indeed, this is part of what makes them so difficult to challenge, both legally and politically.

Ultimately, the demolition of the Sorgenfri camp and other control practices targeting 'vulnerable EU citizens' assume their significance as practices of urban mobility control when viewed against the backdrop of the intersecting citizenship and mobility regimes that deprives mobile poor and racialised EU citizens of most welfare entitlements while positioning them as internal outsiders. As I have shown, the policy response to 'vulnerable EU citizens' turns on the repeated scalardifferentiation and distinction of 'big issues' (like discrimination and racism) and 'small issues' (like garbage disposal and sanitation) in ways that obscure their constitutive linkages. The situation of 'vulnerable EU citizens' in Sweden exposes the basic contradiction at the heart of the welfare state - namely the fact that it is based on the principles of egalitarianism and universalism, yet it is fundamentally premised on the exclusion of non-members. Simultaneously, it also raises a set of complex and politically charged questions about the contradictions and exclusions of the EU citizenship regime and the persistent racialisation and subjugation of the European Roma. I suggest that the 'question of vulnerable EU citizens' is scaled down and reduced to an order and sanitation problem precisely because treating it otherwise would require opening up and rethinking 'big questions' concerning the legitimacy of the national welfare state and the geographies of responsibility and solidarity in Europe. As long as this does not happen, the constitutive exclusions of the current order will continue to manifest in the everyday reality of cities, with responsibility being devolved, almost by default, to the local level authorities.

\section{Suggestions for Further Research}

A multidisciplinary study by its design, this thesis has sought to combine theories from the field of critical border and migration studies with concepts and analytical tools from the legal geographic literature on urban-socio-spatial controls. This bridging of analytical perspectives was 
necessary to make sense of a phenomenon that defies any neat separation between external cross-border mobility control and internal domestic socio-spatial control, between the inside and the outside of the state. I hope to have shown that these perspectives can be usefully combined. There is currently much ongoing discussion within the field of critical migration studies about the need to develop new categories, concepts, and analytical frameworks to better capture the mechanisms of contemporary bordering practices and challenge the 'methodological nationalism' that still marks the field (see Anderson, 2017; Dahinden, 2016; van Baar, 2017c). Theories of scale offer a key theoretical resource to move beyond static conceptions of the state (Glick Schiller \& Çağlar, 2011). Understanding the core mechanisms and politics of urban bordering practices also requires that we engage with the urban as a specific scale of migration governance.

To further develop these perspectives, I think it would be useful to study across the divide between migrant groups (e.g., EU migrants/undocumented/citizens) and across the citizen/migrant divide thus 'de-migratising' migration research. One strategy could be to look at homelessness policy across different categorisations of people and how it intersects with migration policy and law. If it is true that no effective (political) project produces only the consequences it aims to produce, then it becomes imperative to ask about the ripple effects of the policies that have been implemented with regards to 'vulnerable EU citizens'. How do limitations and restrictions on the use of public space affect other categories of urban poor/street-homeless people and the public more generally?

While this study focused on the governance of 'vulnerable EU citizens' as a street-homeless population, it would be relevant to also consider the intersections of work, labour market policy, and (urban) mobility controls in terms of how they sustain the disenfranchisement, impoverishment, and marginalisation of certain EU citizens, especially racialised Roma EU citizens. Formally speaking, 'vulnerable EU citizens' are denied the right of residence for being unemployed and without sufficient means to support themselves. Meanwhile, the limited European research that exists 
on the topic (e.g., Grill, 2015; Mesic, 2016) shows that mobile Roma EU citizens are typically only offered jobs informally (for example, as daylabourers in cleaning, construction, or farm work) and supplied no official record of employment. Consequently, they are disqualified from the right of residence and attendant social protections and rights (see discussion in Ylldı \& De Genova, 2017). Nevertheless, this connection remains underresearched and insufficiently addressed in the Swedish or European policy discourse. Further research on the situation of 'vulnerable EU citizens' within the labour market in Sweden (and across Europe) is therefore needed to more fully understand the relationship between their apparent exclusion from formalised wage labour and the irregularisation of their mobilities. 


\section{REFERENCES}

Abbott, A. (1995). Things Of Boundaries. Social Research, 62(4), 857-882.

Abu-Lughod, L. (2008). Writing against culture. In T. S. Oakes \& P. L. Price (Eds.), The Cultural Geography Reader (pp. 50-59). Abingdon: Routledge.

Agamben, G. (1998). Homo Sacre: Sovereign power and bare life. Stanford: Stanford University Press.

Agamben, G. (2005). State of Exception. Chicago: University of Chicago Press.

Åhman, K. (2015). Judicial Review in Sweden: Some General Observations Regarding the Case Law from the Swedish Domestic Courts. In J. Nergelius \& E. Kristoffersson (Eds.), Human Rights in Contemporary European Law (pp. 7590). Bloomsbury Collections.

Ahmed, S. (2002). Racialized Bodies. In M. Evans \& E. Lee (Eds.), Real bodies: A sociological introduction (pp. 46-63). Basingstoke: Palgrave.

Alkhalili, N. (2017a). Between Sumud and Submission. Palestinian Popular Practices on the Land in the Edge Areas of Jerusalem. Lund University.

Alkhalili, N. (2017). Enclosures from Below: The Mushaa'in Contemporary Palestine. Antipode, 49(5), 1103-1124.

Alveflo, M. (2014, October 27). "Sätt ännu hårdare press på Rumänien”. Expressen. Retrieved from https://www.expressen.se/kvallsposten/satt-annu-hardare-presspa-rumanien/

Amin, S., Lindberg, I., \& Dahlstedt, M. (Eds.). (2002). Det slutna folkhemmet: om etniska klyftor och blågul självbild. Stockholm: Agora.

Amoore, L. (2006). Biometric borders: Governing mobilities in the war on terror. Political Geography, 25(3), 336-351.

Anderson, B. (2013). Us and them? The Dangerous Politics of Immigration Control. Oxford: Oxford University Press.

Anderson, B. (2017). Towards a new politics of migration? Ethnic and Racial Studies, 40(9), 1527-1537. https://doi.org/10.1080/01419870.2017.1300297

Anderson, B., Sharma, N., \& Wright, C. (2009). Editorial: Why No Borders? Refuge, 26(2), 5-18. 
Andersson, J. (2010). Sorgenfri - ett studieobjekt. Retrieved October 18, 2016, from http://norrasorgenfri.blogspot.ca/2010/04/sorgenfri-ett-studieobjekt.html

Ang, I. (2006). Nation; Migration and the City: Mediating Urban Citizenship. In The ESF-LiU Conference Cities and Media: Cultural Perspectives on Urban Identities in a Mediatized World Vadstena; Sweden; 25-29 October; 2 (No. 020). Linköping University Electronic Press.

Appadurai, A. (1998). Dead certainty: Ethnic violence in the era of globalization. Development and change, 29(4), 905-925.

Aradau, C. (2009). The Roma in Italy: Racism as usual? Radical Philosophy, 153(153), 2-7.

Aradau, C. (2015). Security as Universality? The Roma contesting security in Europe. In T. Balzacq (Ed.), Contesting Security: Strategies and Logics (pp. 89103). Abingdon: Routledge.

Aradau, C., Huysmans, J., Macioti, P. G., \& Squire, V. (2013). Mobility interrogating free movement: Roma acts of European citizenship. In E. F. Isin \& M. Saward (Eds.), Enacting European Citizenship (pp. 132-154). Cambridge: Cambridge University Press.

Arendt, H. (1951). The origins of totalitarianism. New York: Schocken Books.

Aronsson, P. (1992). Lokalt folkstyre: kulturarv som utmanar. Stockholm: Svenska Kommunförbundet 2001.

Arvidson, M., Johansson, H., Johansson, S., \& Nordfeldt, M. (2018). Local civil society regimes: liberal, corporatist and social democratic civil society regimes in Swedish metropolitan cities. Voluntary Sector Review, 9(1), 3-20.

Bacchi, C. L. (2009). Analysing Policy: What is the Problem Represented to be? Frencs Forest, N.S.W.: Pearson.

Bacchi, C. L. (2012a). Introducing the 'What's the problem represented to be?' approach. In A. Bletsas \& C. Beasley (Eds.), Engaging with Carol Bacchi: Strategic Interventions and Exchanges (pp. 21-24).

Bacchi, C. L. (2012b). Why Study Problematizations? Making Politics Visible. Open Journal of Political Science, 02(01), 1-8.

Bäckström, H., Örestig, J., \& Persson, E. (2016). The EU Migrant Debate as Ideology: Social Rights, Obligations and Responsibility in the Capitalist Welfare State. Eurozine.

Bagelman, J. (2013). Sanctuary: A politics of ease? Alternatives, 38(1), 49-62.

Bagelman, J. (2016). Sanctuary city: a suspended state. Basingstoke: Palgrave Macmillan. 
Balibar, É. (1991). Is There a "Neo-Racism"? In Race, Nation, Class: Ambiguous Identities (pp. 17-28). London: Verso.

Balibar, É. (2002). Politics and the other scene. London: Verso.

Balibar, É. (2004). We, the People of Europe?: Reflections on transnational citizenship. Princeton, N.J.: Princeton University Press.

Balibar, É. (2009a). Europe as borderland. Environment and Planning D: Society and Space, 27(2), 190-215.

Balibar, É. (2009b). Foreword. In N. Sigona \& N. Trehan (Eds.), Roma politics in contemporary Europe: Poverty, ethnic mobilisation and the neoliberal order (pp. viii-xiii). London: Palgrave Macmillan.

Barker, V. (2017). Nordic vagabonds: The Roma and the logic of benevolent violence in the Swedish welfare state. European Journal of Criminology, 14(1), $120-139$.

Barker, V. (2018). Nordic Nationalism and Penal Order: Walling the Welfare State. Abingdon \& New York: Routledge.

Bauder, H. (2017). Sanctuary Cities: Policies and Practices in International Perspective. International Migration, 55(2), 174-187.

Bauman, Z. (1987). Legislators and Interpreters. Oxford: Polity Press.

Beier, A. L. (1985). Masterless men: the vagrancy problem in England 1560-1640. London: Methuen.

Bengtsson, B. (2001). Housing as a Social Right: Implications for Welfare State Theory. Scandinavian Political Studies, 24(4), 255.

Bergman, F. (2018). Gatans entreprenörer. Stockholm: Verbal.

Bhabha, H. K. (1999). The other question: difference, discrimination and the discourse of colonialism. In J. Evans \& S. Hall (Eds.), Visual Culture: The Reader (pp. 370-378). London: SAGE in association with the Open University.

Bhandar, B. (2018). Organised State Abandonment: The Meaning of Grenfell. [blog post] Retrieved from http://criticallegalthinking.com/2018/09/21/organised-stateabandonment-the-meaning-of-grenfell/

Bigo, D. (2002). Security and Immigration: Toward a Critique of the Governmentality of Unease. Alternatives, 27(1), 63-92.

Bigo, D. (2008). Globalized (in)security: The field and the ban-opticon. Terror Insecurity and Liberty: Illiberal Practices of Liberal Regimes After 9/11, 10-48. https://doi.org/10.4324/9780203926765

Blomley, N. (1994). Mobility, empowerment and the rights revolution. Political Geography, 13(5), 407-422. 
Blomley, N. (2007). Civil rights meet civil engineering: Urban public space and traffic logic. Canadian Journal of Law \& Society/La Revue Canadienne Droit et Société, 22(2), 55-72.

Blomley, N. (2007b). How to Turn a Beggar into a Bus Stop: Law, Traffic and the "Function of the Place." Urban Studies, 44(9), 1697-1712.

Blomley, N. (2010). The Right to Pass Freely: Circulation, Begging, and The Bounded Self. Social \& Legal Studies, 19(3), 331-350.

Blomley, N. (2011). Rights of Passage: sidewalks and the regulation of public flow. New York: Routledge.

Blomley, N. (2012). 2011 Urban geography plenary lecture-colored rabbits, dangerous trees, and public sitting: Sidewalks, police, and the city. Urban Geography, 33(7), 917-935.

Blomley, N. (2013). What sort of a legal space is a city? In A. M. Brighenti (Ed.), Urban Interstices: The Aesthetics and the Politics of the In-Between (pp. 1-20).

Blomley, N., \& Pratt, G. (2001). Canada and the political geographies of rights. Canadian Geographer/Le Géographe Canadien, 45(1), 151-166.

Bosma, U., Kessler, G., \& Lucassen, L. (2013). Migration and membership regimes in global and historical perspective: An introduction. In Migration and Membership Regimes in Global and Historical Perspective: An Introduction (pp. 1-319).

Bosniak, L. (2007). Being Here: Ethical Territoriality and the Rights of Immigrants. Theoretical Inquiries in Law, 8(2), 389-410.

Brand i läger misstänks vara anlagd. (2014, November 11). Sveriges Radio P4 Malmöhus.

Brännström, L. (2009). Förrättsligande: en studie av rättens risker och möjligheter med fokus på patientens ställning. Lund University.

Brännström, L. (2009). Förrättsligande: en studie av rättens risker och möjligheter med fokus på patientens ställning. PhD Dissertation: Lunds universitet.

Brännström, L. (2016). "Ras" i efterkrigstidens Sverige: ett bidrag till en mothistoria. In P. Lorenzoni \& U. Manns (Eds.), Historiens hemvist: II Etik, politik och historikerns ansvar (pp. 27-55). Göteborg: Makadam förlag.

Brännström, L. (2017). Juridik som politik och om behovet av kritik. In L. Pelling \& P. Hall (Eds.), Rätten till rättvisa: Om utsatta människors rättigheter och tillgång till rättvisa (pp. 60-75). Premiss förlag.

Bråttsförebyggande rådet. (2015). Hatbrott 2014.

Brenner, N. (1997). Geographies of Globalization. Public culture, 10(1), 135-167. 
Brenner, N. (2001). The limites to scale: Methodlogical refelctions on scalar structuration. Progress in Human Geography, 4, 591-614.

Brentlin, R., \& Israelson, A. (2014). Vi kallar dem tiggare.. Stocksund: Hydra in collaboration with Migro.

Bro, A. (2000). Från hälsovård till miljöskydd: En historisk institutionell analys av kommunal ansvarsutveckling. PhD Dissertation. Örebro universitet.

Broberg, G., \& Tydén, M. (1991). Oönskade i folkhemmet: rashygien och sterilisering $i$ Sverige. Stockholm: Gidlund.

Brown, W. (1993). Wounded Attachments. Political Theory, 21(3), 390-410.

Brown, W. (2000). Suffering Rights as Paradoxes. Constellations Volume, 7(2), 230-241.

Brown, W. (2004). “The Most We Can Hope For...": Human Rights and the Politics of Fatalism. South Atlantic Quarterly, 103(2-3), 451-463.

Brown, W., \& Halley, J. E. (Eds.). (2002). Left Legalism/Left Critique. Durham, N.C.: Duke University Press.

Bunescu, I. (2014). Roma in Europe: The Politics of Collective Identity Formation. Roma in Europe: The Politics of Collective Identity Formation. Farnham: Ashgate.

Burchell, G., Gordon, C., \& Miller, P. (Eds.). (1991). The Foucault effect: studies in governmentality : with two lectures by and an interview with Michel Foucault. Chicago: University of Chicago Press.

Buroway, M. (2009). The Extended Case Method: Four Countries, Four Decades, Four Great Transformations, and One Theoretical Tradition. Berkeley \& Los Angeles: University of California Press.

Burridge, A., Gill, N., Kocher, A., \& Martin, L. (2017). Polymorphic borders. Territory, Politics, Governance, 5(3), 239-251.

Butler, J. (1993). Bodies that Matter: On the discursive limits of "sex." New York: Routledge.

Campkin, B. (2013). Placing "matter out of place": Purity and danger as evidence for architecture and urbanism. Architectural Theory Review, 18(1), 46-61.

Carrera, S. (2014). The Framing of the Roma as Abnormal EU Citizens: Assessing European Politics on Roma Evictions and Expulsions in France. In Guild, E., Goratázar, C. J., and Rotaeche, D. K. (Eds.) The Reconceptualization of European Union Citizenship (pp. 33-63). Brill Nijhoff.

Castles, S. (2004). Why migration policies fail. Ethnic and Racial Studies, 27(2), 205-227.

Centrum för Sociala Rättigheter. (2015). Överklagan Av Beslut Om Rättelse. 
Chakrabarty, B., \& Bhattacharya, M. (Eds.). (2008). The Governance Discourse: A Reader. New Delhi; New York: Oxford University Press.

Chatty, M. (2015). Migranternas medborgarskap: EU:s medborgarskapande från Romförhandlingarna till idag. PhD Dissertation. Örebro University.

Ciulinaru, D. (2017). The Justification of Harsh Treatment of Homeless Romanian Migrants in Sweden. Nordic Journal of Migration Research, 7(4), 243-250.

Civil Rights Defenders (2015). Stoppa avhysningen från boplatsen på Sorgenfri. Retrieved from http://www.civilrightsdefenders.org/files/Öppet-brev-CivilRights-Defenders2.pdf

Civil Rights Defenders (2017). Utsatta unionsmedborgare i Sverige: Statens skyldigheter enligt internationella människorättsnormer, EU-rätt och svensk rätt.

Clough Marinaro, I. (2009). Between surveillance and exile: Biopolitics and the Roma in Italy. Bulletin of Italian Politics, 1(2), 265-87.

Clough Marinaro, I. (2014b). Rome's 'legal' camps for Roma: the construction of new spaces of informality. Journal of Modern Italian Studies, 19(5), 541-555. https://doi.org/10.1080/1354571X.2014.962254

Clough Marinaro, I. (2014c). Sporco zingaro: I rom e l'integrità del corpo della nazione. In C. Lombardi-Diop \& C. Romeo (Eds.), Italia postcoloniale (pp. 91106). Firenze: Le Monnier.

Clough Marinaro, I. (2015). The Rise of Italy's Neo-Ghettos. Journal of Urban History, 41(3), 368-387.

Clough Marinaro, I. (2017). The informal faces of the (neo-)ghetto: State confinement, formalization and multidimensional informalities in Italy's Roma camps. International Sociology, 32(4), 545-562.

Clough Marinaro, I. (2019). Informality and the Neo-Ghetto: Modulating Power Through Roma Camps. in Flint, J. and Powell, R. (Eds.) Class, Ethnicity and State in the Polarized Metropolis (pp. 159-185). Palgrave Macmillan, Cham.

Clough Marinaro, I., \& Daniele, U. (2011). Roma and humanitarianism in the Eternal City. Journal of Modern Italian Studies, 16(5), 621-636.

Clough Marinaro, I., \& Sigona, N. (2011). Anti-Gypsyism and the politics of exclusion: Roma and Sinti in contemporary Italy. Journal of Modern Italian Studies, 16(5), 583-589.

Cohen, S. (1987). Folk Devils and Moral Panics: The Creation of the Mods and Rockers. Oxford: Basil Blackwell.

Coleman, M. (2009). What counts as the politics and practice of security, and where? devolution and immigrant insecurity after 9/11. Annals of the Association of American Geographers, 99(5), 904-913. 
Coleman, M. (2012a). Immigrant Il-Legality: Geopolitical and Legal Borders in the US, 1882-Present. Geopolitics, 17(2), 402-422.

Coleman, M. (2012b). The "Local" Migration State: The Site-Specific Devolution of Immigration Enforcement in the U.S. South. Law and Policy, 34(2), 159-190.

Coleman, M., \& Grove, K. (2009). Biopolitics, biopower, and the return of sovereignty. Environment and Planning D: Society and Space, 27(3), 489-507.

Coleman, M., \& Kocher, A. (2019). Rethinking the "Gold Standard" of Racial Profiling: §287(g), Secure Communities and Racially Discrepant Police Power. American Behavioral Scientist, 0002764219835275.

Coleman, M., \& Stuesse, A. (2016). The Disappearing State and the Quasi-Event of Immigration Control. Antipode, 48(3), 524-543.

Cooper, D. (2002). Far beyond "the early morning crowing of a farmyard cock": Revisiting the place of nuisance within legal and political discourse. Social and Legal Studies.

CORAM. (2013). Growing Up In A Hostile Environment: The rights of undocumented migrant children in the UK. Retrieved from https://www.childrenslegalcentre.com

Corporate Watch. (2018). The UK Border Regime: a critical guide. London: Corporate Watch. Retrieved from www.corporatewatch.org

Council of Europe. (2012). Council of Europe: Descriptive Glossary of terms relating to Roma issues. Retrieved from http://a.cs.coe.int/team20/cahrom/documents/Glossary Roma EN version 18 May 2012.pdf

Cresswell, T. (1997). Weeds, plagues, and bodily secretions: a geographical interpretation of metaphors of displacement. Annals of the Association of American Geographers, 87(2), 330-345.

Creţan, R., \& Powell, R. (2018). The Power of Group Stigmatization: Wealthy Roma, Urban Space and Strategies of Defence in Post-socialist Romania. International Journal of Urban and Regional Research, 42(3), 423-441.

Crofts, P., Hubbard, P., \& Prior, J. (2013). Policing, planning and sex: Governing bodies, spatially. Australian \& New Zealand Journal of Criminology, 46(1), 5169.

Dahinden, J. (2016). A plea for the 'de-migranticization'" of research on migration and integration 1.' Ethnic and Racial Studies, 39(13), 2207-2225.

Darling, J. (2011). Domopolitics, governmentality and the regulation of asylum accommodation. Political Geography, 30(5), 263-271. 
Darling, J. (2017). Forced migration and the city: Irregularity, informality, and the politics of presence. Progress in Human Geography, 41(2), 178-198. Davidsson, T. (2015). Understödets rationalitet.

Davis, M. F., \& Ryan, N. (2016). Inconvenient human rights: Access to water and sanitation in Sweden's informal Roma settlements. Raoul Wallenberg Institute, Sodertörn University, and NuLawLab (April 2016).

De Genova, N. (2002). Migrant "Illegality” and Deportability in Everyday Life. Annual Review of Anthropology, 31(1), 419-447.

De Genova, N. (2007). The Production of Culprits: From Deportability to Detainability in the Aftermath of "Homeland Security." Citizenship Studies, 11(5), 421-448.

De Genova, N. (2013). "We are of the connections": migration, methodological nationalism, and 'militant research. Postcolonial Studies, 16(3), 250-258.

Dikec, M., Clark, N., \& Barnett, C. (2009). Extending hospitality: Giving space, taking time. Paragraph: A Journal of Modern Critical Theory, 32(1), 1-14.

Dillon, L. (2013). Race, Waste, and Space: Brownfield Redevelopment and Environmental Justice at the Hunters Point Shipyard. Antipode, 46(5), 12051221.

Djuve, A. B., Friberg, J. H., Tyldum, G., \& Zhang, H. (2015). When poverty meets affluence. Migrants from Romania on the streets of the Scandinavian capitals, The Rockwool Foundation, Oslo.

Douglas, M. (2002). Purity and Danger: An analysis of concepts of pollution and taboo. London: Routledge.

Dworkin, R. (1977). Taking Rights Seriously. Cambridge, MA: Harvard University Press.

Edman, J. (2008). Lösdrivarlagen och den samhällsfarliga lättjan. In H. Swärd \& M.-A. Egerö (Eds.), Villkorandets politik : fattigdomens premisser och samhällets åtgärder - då och nu (pp. 131-143). Malmö : Égalité.

Ekström von Essen, U. (2003). Folkhemmets kommun: Socialdemokratiska idéer om lokalsamhället 1939-1952. Stockholm: Atlas Akademi.

Ellis, M. (2006). Unsettling immigrant geographies: US immigration and the politics of scale. Tijdschrift Voor Economische En Sociale Geografie, 97(1), 49-58.

Elwood, S., Lawson, V., \& Sheppard, E. (2017). Geographical relational poverty studies. Progress in Human Geography, 41(6), 745-765.

Emirov, S. (2016). Varför tigger romer? Falun: Scandbook. 
Engebrigtsen, A. I. (2012). Tiggerbander og kriminelle bakmenn eller fattige EUborgere? Myter og realiteter om utenlandske tiggere i Oslo. Retrieved from http://www.nova.no/asset/5541/1/5541_1.pdf

Engebrigtsen, A. I. (2015). Invading Our homelands. New beggars in the streets of Oslo. In M. Johansson, T. Salonen, \& E. Righard (Eds.), Social Transformation in Scandinavian Cities. Nordic Perspectives on Urban Marginalisation and Social Sustainability (pp. 143-161). Nordic Academic Press. WHAT CITY?

Engebrigtsen, A. I., Fraenkel, J., \& Pop, D. (2014). Gateliv: Kartlegging av situasjonen til utenlandska personer som tigger. Retrieved from http://www.hioa.no/content/download/60071/1006123/file/Gateliv-Utenlandskepersoner-som-tigger.pdf

Ericsson, M. (2015). Exkludering, assimilering eller utrotning? "Tattarfrågan" $i$ svensk politik 1880-1955. PhD Dissertation. Lunds universitet.

Farget, D. (2012). Defining Roma Identity in the European Court of Human Rights. International Journal on Minority and Group Rights, 19(3), 291-316.

Fauser, M. (2019). The Emergence of Urban Border Spaces in Europe. Journal of Borderlands Studies, 34(4), 605-622.

Fekete, L. (2014). Europe against the Roma. Race \& Class, 55(3), 60-70.

Fjellman, E. (2015, March 25). EU-migranter protesterade i Malmö kommunfullmäktige. Sydsvenskan.

Flyvbjerg, B. (2006). Five Misunderstandings About Case-Study Research. Qualitative Inquiry, 12(2), 219-245.

Forsell, M. (2015, January 13). Larm om att källare användes i Sofielund. Skånska Dagbladet.

Foucault, M. (1982). The Subject and Power. Critical Inquiry, 8(4), 777-795.

Foucault, M. (1990). The History of Sexuality Vol. 1: The Will to Knowledge. Harmondsworth: Penguin.

Foucault, M. (1991). Discipline and Punish: The birth of the prison. Harmondsworth: Penguin.

Foucault, M. (2003). Society Must Be Defended: Lectures at the Collège de France, 1975-76. New York: Picador.

Foucault, M. (2007). Security, territory, population: lectures at the Collège de France, 1977-1978. (M. Senellart, A. I. Davidson, F. Ewald, \& A. Fontana, Eds.). Houndmills, Basingstoke, Hampshire: Palgrave Macmillan.

Foucault, M. (2010). The Birth of Biopolitics: lectures at the Collège de France, 1978-1979. (M. Senellart, Ed.). New York: Picardor. 
Fouteau, C., Fassin, E., Guichard, S., \& Windels, A. (2014). Roms \& riverains: Une politique municipale de la race. Paris: La Fabrique éditions.

Franzén, M. (2001). Urban order and the preventive restructuring of space: the operation of border controls in micro space. The Sociological Review, 49(2), 202218.

Franzén, M., Hertting, N., \& Thörn, C. (2016). Stad till salu: Entreprenörsurbanismen och det offentliga rummets värde. Göteborg: Diadalos.

Fraser, N. (2009). Scales of Justice: Reimagining Political Space in a Globalizing World. New York: Columbia University Press.

Fuller, D., \& Kitchin, R. (Eds.). (1981). Radical Theory/Critical Praxis: Making a Difference Beyond the Academy. Victoria, BC: Praxis (e)Press.

Funke, M. (2016, November 5). Efter rivningen av Sorgenfrilägret : 161 klagomål på olovliga boenden. Sydsvenskan, pp. 1-6. Retrieved from https://www.sydsvenskan.se/2016-11-05/efter-rivningen-avsorgenfrilagret?redirected $=1$

Garapich, M. (2016). London's Polish Borders: Transnationalizing Class and Ethnicity Among Polish Migrants in London. Stuttgart and Hannover: ibidem Press.

Gehring, J. S. (2013). Free Movement for Some: The Treatment of the Roma after the European Union's Eastern Expansion. European Journal of Migration \& Law, 15(1), 7-28.

Ghertner, D. A. (2010). Calculating without numbers: aesthetic governmentality in Delhi's slums. Economy and Society, 39(2), 185-217.

Ghertner, D. A. (2012). Nuisance Talk and the Propriety of Property: Middle Class Discourses of a Slum-Free Delhi. Antipode, 44(4), 1161-1187.

Ghertner, D. A. (2015). Rule by Aesthetics: World-Class City Making in Delhi. New York: Oxford University Press.

Gidwani, V., \& Reddy, R. N. (2011). The Afterlives of "Waste": Notes from India for a Minor History of Capitalist Surplus. Antipode , 43(5), 1625-1658.

Glick Schiller, N., \& Çağlar, A. (Eds.). (2011). Locating migration: rescaling cities and migrants. Ithaca, N.Y.: Cornell University Press.

Goldberg, D. T. (2006). Racial Europeanization. Ethnic and Racial Studies, 29(2), 331-364.

Goldberg, D. T. (2009). The Threat of Race. Reflections on Racial Neoliberalism. Malden: Wiley Blackwell. 
Goldberg, D. T., \& Solomos, J. (2002). General Introduction. In D. T. Goldberg \& J. Solomos (Eds.), A Companion to Racial and Ethnic Studies (pp. 1-12). Malden: Blackwell Publishing.

Goodwin, M., \& Buijs, R. (2013). Making Good European Citizens of the Roma: A Closer Look at the EU Framework for National Roma Integration Strategies. German Law Journal, 14(10), 2041-2056.

Gordon, C. (1991). Governmental rationality: an introduction. In The Foucault Effect: Studies in Governmentality (pp. 1-48). Chicago: University of Chicago Press.

Goździak, E. M. (2016). Trafficked Children and Youth in the United States: Reimagining survivors. New Brunswick: Rutgers University Press.

Grill, J. (2015). 'Endured labour' and 'fixing up' money: The economic strategies of Roma migrants in Slovakia and the UK. In M. Brazzabeni, M. I. Cunha \& Fotta, M. Gypsy Economy: Romani Livelihoods and Notions of Worth in the 21st Century (pp. 88-106). New York: Berghan Books.

Guild, E., \& Bigo, D. (2010). The Transformation of European Border Controls. In R. Bernard \& M. Valsamis (Eds.), Extraterritorial Immigration Control: Legal Challenges (pp. 252-273). Leiden: Nijhoff.

Gurt, S. (2015). Ni inger dessa människor hopp: en berättelse om tiggarna och om några som hjälper dem. Stockholm: Wahlström \& Widstrand.

Gusterson, H. (1997). Studying up revisited. PoLAR: Political and Legal Anthropology Review, 20(1), 114-119.

Habul, K. (2014, September 20). Tvåbarnsfar död efter brand i romskt läger. Aftonbladet. Retrieved from http://www.aftonbladet.se/nyheter/article19566975.ab

Hacking, I. (1975). The emergence of probability : a philosophical study of early ideas about probability, induction and statistical inference. London: Cambridge University Press.

Hage, G. (2009). Hating Israel in the Field. Anthropological Theory, 9(1), 59-79.

Hall, S., Critcher, C., Jefferson, T., Clarke, J., \& Roberts, B. (Eds.). (1978). Policing the crisis : mugging, the state, and law and order. London: Macmillan.

Hammarberg, T. (2019). Thomas Hammarberg: Avhysningar kränker mänskliga rättigheter. Dagens Arena. Retrieved from: https://www.dagensarena.se/opinion/thomas-hammarberg-avhysningar-krankermanskliga-rattigheter/

Hansen, C. (2019). Solidarity in Diversity: Activism as a Pathway of Migrant Emplacement in Malmö. PhD Dissertation. Malmö University. 
Hansen, P. (2000). "European Citizenship", or where neoliberalism meets ethnoculturalism - Analysing the European Union's citizenship discourse. European Societies, 2(2), 139-165.

Hansen, P. (2015). 'Undermining Free Movement: Migration in an Age of Austerity'. Eurozine, 1-6.

Hansson, E. (2014). "Som att världen har kommit hit" Stockholmares upplevelser av tiggeri våren 2014. MA Thesis. Stockholm University.

Hansson, E. (2015). Hotet mot det svenska samhällskontraktet - Hur tiggeri i Stockholm aktiverar det personliga moraliska ansvaret. Socialmedicinsk Tidskrift, 92(3), 343-351.

Hansson, E. (2019). “Det känns fel” Om det svenska samhällets reaktioner på närvaron av tiggande EU-medborgare, 2014-2016. PhD Dissertation. Uppsala Universitet.

Hansson, E., \& Jansson, D. (2019). Who's afraid of the 'beggar'? A psychoanalytic interpretation of the crises triggered by the begging of 'EU migrants' in Sweden. Social and Cultural Geography, 1-18.

Hansson, E., \& Mitchell, D. (2018). The Exceptional State of “ Roma Beggars " in Sweden. European Journal of Homelessness, 12(1), 15-40.

Hansson, E., \& Persdotter, M. (2019). Vad är den svenska modellen? socialdemokratisk historieskrivning i den samtida "tiggeridebatten. In P. Brunnström \& R. Claesson (Eds.), Creating the city - Identity, memory and participation. Conference proceedings. Institute for studies in Malmö's history, Malmö University.

Haraway, D. J. (1988). Situated Knowledges: The Science Question in Feminism and the Privilege of Partial Perspective. Feminist Studies, 14(3), 575-599.

Harding, S., \& Norberg, K. (2005). New Feminist Approaches to Social Science Methodologies: An Introduction. Signs, 30(4), 2009-2015.

Hatton, J. (2018). MARS Attacks! A Cautionary Tale from the UK on the Relation between Migration and Refugee Studies (MARS) and Migration Control.

Movements. Journal for Critical Migration and Border Regime Studies, 4(1), $103-129$.

Hawkins, K. (Ed.). (1994). The Uses of Discretion. Oxford: Clarendon.

Hayden, R. M. (1996). Imagined Communities and Real Victims: Self-

Determination and Ethnic Cleansing in Yugoslavia. American Ethnologist, 23(4), 783-801.

Henley, J. (2019). Swedish town launches controversial $£ 21$ begging permit. The Guardian. Retrieved from 
https://www .theguardian.com/world/2019/aug/05/swedish-town-launchescontroversial-21-begging-permit

Hepworth, K. (2012). Abject citizens: Italian 'Nomad Emergencies' and the deportability of Romanian Roma. Citizenship Studies, 16(3), 431-449.

Hesse, B. (2007). Racialized modernity: An analytics of white mythologies. Ethnic and Racial Studies, 30(4), 643-663.

Hirdman, Y. (1989). Att lägga livet till rätta: Studier i svensk folkhemspolitik. Stockholm: Carlsson.

Holgersen, S. (2017). Staden och kapitalet: Malmö i krisernas tid. Göteborg: Daidalos.

Holgersson, H. (2011). Icke-medborgarskapets urbana geografi. PhD Dissertation. Göteborg: Göteborgs universitet, 2011.

Holm, G. (2015, November 9). Avhysning av olagliga migrantläger ett lotteri. Expressen. Retrieved from https://www .expressen.se/nyheter/avhysning-avolagliga-migrantlager-ett-lotteri/

Hörnqvist, M. (2010). Risk, Power and the State: After Foucault. London: Routledge.

Hubbard, P. (2013). Kissing is not a universal right: Sexuality, law and the scales of citizenship. Geoforum, 49(August), 224-232.

Husa, J. (2010). Nordic Constitutionalism and European Human Rights-Mixing Oil and Water?. Scandinavian Studies in Law, 55, 101-124.

Huxley, M. (2007). Geography of Governmentality. In J. Crampton \& S. Elden (Eds.), Space, Knowledge, Power: Foucault and Geography (pp. 185-205). Aldershot: Ashgate.

Hyndman, J. (2000). Managing Displacement: Refugees and the Politics of Humanitarianism. Minneapolis: Minnesota University Press.

Ignatieff, M. (2000). The Rights Revolution. Toronto: House of Anansi Press.

Ingvarson, J. (2016, July 12). Svårare läge för hemlösa EU-medborgare. Sveriges Radio P4 Malmöhus.

Iossa, A. (2017). Collective Autonomy in the European Union Theoretical, Comparative and Cross-border Perspectives on the. $\mathrm{PhD}$ Dissertation. Lund University.

Isin, E. (2002). Being Political: genealogies of citizenship. Minneapolis, Minn.: University of Minnesota Press.

Isin, E. (2007). City.State: Critique of Scalar Thought. Citizenship Studies, 11(2), 211-228. 
Ivasiuc, A. (2015a). Securitising the Roma, purifying Rome. The rhetoric of insecurity, urban decay and everyday practices of purification. In $R C 21$ International Conference on "The Ideal City": Between Myth and Reality [conference proceedings]. Urbino, Italy.

Ivasiuc, A. (2015b). Watching over lhe Neighbourhood. Etnofoor, 27(2), 53-72.

Johansen, N. B. (2016). Controlling Roma in Norway: governing through the administration of social distance. In A. Eriksson (Ed.), Punishing the other: the social production of immorality revisited. Abingdon, Oxon: Routledge.

Johansson, T. (2016). Vårt fredliga samhälle: "Lösdriveri” och försvarslöshet $i$ Sverige under 1830-talet. PhD Dissertation. Uppsala Universitet.

Jones, H., Gunaratnam, Y., Bhattacharyya, G., Davies, W., Dhaliwal, S., Forkert, K., ... Saltus, R. (2017). Go home? The politics of immigration controversies. Manchester: Manchester University Press. Retrieved from http://www.ncbi.nlm.nih.gov/pubmed/11973938

Joppke, C. (2007). Transformation of Citizenship: Status, Rights, Identity. Citizenship Studies, 11(1), 37-48.

Karlsson, J. (2015, December 3). Lägret i Sorgenfri - ödetomten som blev Sveriges största slum. Expressen. Retrieved from https://www.expressen.se/nyheter/longread/darfor-kommer-tiggarna/sv/lagret-isorgenfri--odetomten-som-blev-sveriges-storsta-slum/

Katz, C. (1994). Playing the Field: Questions of Fieldwork in Geography. Professional Geographer, 46(1), 67-72.

Keenan, S. (2017). A Border In Every Street. Retrieved from https://thedisorderofthings.com/2017/06/29/a-border-in-every-street

Keskinen, S. (2016). From welfare nationalism to welfare chauvinism: Economic rhetoric, the welfare state and changing asylum policies in Finland. Critical Social Policy, 36(3), 352-370.

Kjellbom, P., \& Lundberg, A. (2018). Olika rättsliga rum för en skälig levnadsnivå? EN rättskartografisk analys av SoL och LMA i domstolspraktiken. Nordisk Socialrättslig Tidskrift, 1-18, 39-71.

Klodawsky, F., \& Blomley, N. (2009). Introduction-Rights, Space, and Homelessness. Urban Geography, 30(6), 573-576.

Knutagård, M. (2009). Skälens fångar: hemlöshetsarbetets organisering, kategoriseringar och förklaringar.PhD Dissertation. Lunds universitet.

Kóczé, A. (2017). Race, migration and neoliberalism: distorted notions of Romani migration in European public discourses. Social Identities, 4630(June), 1-15.

Koefoed, L., \& Simonsen, K. (2007). The price of goodness: Everyday nationalist narratives in Denmark. Antipode, 39(2), 310-330. 
Koefoed, L., \& Simonsen, K. (2011). "The stranger”, the city and the nation: On the possibilities of identification and belonging. European Urban and Regional Studies, 18(4), 343-357.

Köning Jerlmyr, A. (2015, February 25). Därför måste vakter få avhysa bosättningarna. Dagens Samhälle. Retrieved from

https://www.dagenssamhalle.se/debatt/daerfoer-maste-vakter-fa-avhysabosaettningarna-13966

Kristeva, J. (1982). Powers of Horror: An Essay on Abjection. Trans. Leon Roudiez. New York: Columbia University Press. DO YOU NEED TO MENTION THE TRANSLATOR?

Kronofogden. (2015). Handräckningar rörande otillåten bosättning: Statistik för 2015.

Kulturdepartementet. (2016). Regeringens strategi för romsk inkludering: Faktablad.

Kvale, S. (1997). Den kvalitativa forskningsintervjun. Lund: Studentlitteratur.

Lacatus, T. (2015). Studie om hatbrott och andra allvarliga kränkningar riktade mot utsatta romska. Retrieved from http://motantiziganism.se/wpcontent/uploads/2016/01/Tiberiu-Lacatus-Studie-om-hatbrott-och-andraallvarliga-kränkningar-riktade-mot-utsatta-romska-EU-medborgare.pdf

Lafleur, J. M., \& Mescoli, E. (2018). Creating Undocumented EU Migrants through Welfare: A Conceptualization of Undeserving and Precarious Citizenship. Sociology, 52(3), 480-496.

Lagen måste gälla alla. Även utsatta EU-migranter. (2015, September 25). Sydsvenskan.

Lagerlöf, B., \& Freiholtz, C. (2017). Jag kallas tiggare. Johanneshov: LL-förlaget. Länsstyrelsen Skåne. (2018). Lägesbild avseende utsatta EU-medborgare i Skåne län.

Larsson, B., Letell, M. \& Thörn, H. (Eds.) (2012). Transformations of the Swedish Welfare State: From social engineering to governance?. New York: Palgrave Macmillan.

Lauffs, T. (2015, November 3). Soraya Post: "Jag skäms för Sverige”. SVT Nyheter.

Law, I., \& Kovats, M. (2018). Rethinking Roma: Identities, Politicisation and New Agendas. London: Palgrave Macmillan.

Legros, O., \& Vitale, T. (2011). Les migrants roms dans les villes françaises et italiennes : mobilités, régulations et marginalités. Géocarrefour, 86(1), 3-14. Retrieved from http://journals.openedition.org/geocarrefour/8220 
Lemke, T. (2007). An indigestible meal? Foucault, governmentality and state theory. Distinktion: Journal of Social Theory, 8(2), 43-64.

Lentin, A. (2017a). De-racing the Border. Retrieved from http://www.alanalentin.net/2017/05/11/de-racing-the-border/

Lentin, A. (2017b). On relationality in race research. Retrieved February 20, 2017, from http://www.alanalentin.net/

Levi, R. (2008). Loitering in the City That Works. In M. D. Dubber \& M. Valverde (Eds.), Police and the Liberal State. Stanford: Stanford University Press.

Levy, J. (2016). A Right to the 'World-Class City'? A case study on the spatial exclusions of Romanian Roma. Stockholm University.

Lind, J., \& Persdotter, M. (2017). Differential Deportability and Contradictions of a Territorialised Right to Education. A Perspective from Sweden. Movements. Journal Für Kritische Migrations- Und Grenzregimeforschung, 3(1), 51-69.

Lipsky, M. (1980). Street-level Bureaucracy: Dilemmas of the individual in public services. New York: Russell Sage Foundation.

Listerborn, C. (2018). Bostadsojämnlikhet: Röster om bostadsnöden. Stockholm: Premiss.

Lönnaeus, O., Fjellman, E., Magnusson, E., Frennesson, P., \& Cronqvist, K. (2016, June 26). Så blev Malmö en av Sveriges fattigaste städer. Sydsvenskan. Retrieved from https://www.sydsvenskan.se/2016-06-26/sa-blev-malmo-fattigast-i-sverige

Low, S. M., \& Lawrence-Zúñiga, D. (2003). Locating Culture. In S. M. Low \& D. Lawrence-Zúniga (Eds.), The anthropology of space and place: Locating culture (pp. 1-47). Oxford: Blackwell Publishing.

Lucassen, L. (1998). 'Eternal Vagrants? State Formation, Migration and Travelling Groups in Western Europe, 1350-1914. In L. Lucassen, W. Willems, \& A. Cottaar (Eds.), Gypsies and Other Itinerant Groups. A Socio-Historical Approach (pp. 55-73). Blasingstoke: Macmillan.

Lucassen, L. (2010). A brave new world: The left, social engineering, and eugenics in twentieth-century Europe. International Review of Social History, 55(2), 265296.

Lucassen, L. (2012). Cities, States and Migration Control in Western Europe: Comparing Then and Now. In B. De Munck \& A. Winter (Eds.), Gated Communities? Regulating Migration in Early Modern Cities. Burlington, VT: Ashgate.

Lucassen, L. (2018). Peeling an onion: The "refugee crisis" from a historical perspective. Ethnic and Racial Studies, 41(3), 383-410.

Lucassen, L., Willems, W., \& Cottaar, A. (1998). Gypsies and Other Itinerant Groups: A socio-historical Approach. Basingstoke: Macmillan. 
Lundberg, A., \& Dahlquist, L. (2018). Sanctuary practices in scandinavian transnational cities: The case of public libraries. Journal of Human Rights Practice, 10(1), 142-158.

Lundberg, A., \& Spång, M. (2017). Deportability Status as Basis for Human Rights Claims : Irregularised Migrants ' Right to Health Care in Sweden. Nordic Journal of Human Rights, 35(1), 35-54.

Lundberg, A., \& Strange, M. (2017). Who provides the conditions for human life? Sanctuary movements in Sweden as both contesting and working with state agencies. Politics, 37(3), 347-362.

Maestri, G. (2017). Struggles and ambiguities over political subjectivities in the camp: Roma camp dwellers between neoliberal and urban citizenship in Italy. Citizenship Studies, 21(6), 640-656.

Maestri, G. (2019). Temporary camps, enduring segregation: the contentious politics of Roma and migrant housing. Cham, Switzerland: Palgrave Macmillan.

Magnusson, E. (2015, November 4). Fullt av beröm i Carina Nilssons mejlbox. Sydsvenskan.

Magyari-Vincze, E., Petrovici, N., Rat,, C., \& Picker, G. (Eds.). (2019). Racialized Labour in Romania: Spaces of marginality at the periphery of global capitalism. Cham, Switzerland: Palgrave Macmillan.

Malkki, L. (1995). Purity and Exile: Violence, Memory, and National Cosmology among Hutu Refugees in Tanzania. Chicago: University of Chicago Press.

Malm, V. (2015, October 30). Vräkningen i Malmö beror på rasistisk logik. Expressen.

Malmö stad. (2014). Socialt utsatta EU-medborgare i Malmö - deras situation och behov. Retrieved from https://malmo.se/download/18.76b7688614bb5ccea0943571/1491300280302/EU -migranter\%2B-\%2B\%2Brapport.pdf

Malmö stad. (2015). Malmö stads handlingsplan för arbetet med fattiga och socialt utsatta EU-medborgare i Malmö.

Malmö stad. (2018). City of Malmö: Annual Report and Statement of Accounts 2018. Retrieved from https://malmo.se/download/18.198e132616aa40a135a1113f/1560416795675/Ann ual+report+and+statement+of+accounts+2018+City+of+Malmö.pdf

Malmö Stad - Fastighetskontoret. (2007). Norra Sorgenfri, Markmiljöutredning. Retrieved from http://norrasorgenfri.blogspot.se/

Malmö stad Miljöförvaltningen. (2015). Förbud mot boende och övernattning m.m. på fastigheten Brännaren 19. 
Malmö Stad Miljöförvaltningen. (2015). Föreläggande vid vite avseende nedskräpning på fastigheten Brännaren 19. Delegationsbeslut.

Marcuse, P. (1988). Neutralizing Homelessness. Socialist Review, 88(1), 68-97.

Marshall, T. H. (1950). Citizenship and social class and other essays. Cambridge, U.K.

Marston, S. A. (2000). The social construction of scale. Progress in Human Geography, 24(2), 219-242.

Marston, S. A., \& Smith, N. (2001). States, scales and households: limits to scale thinking? A response to Brenner. Progress in Human Geography, 25(4), 615619.

Martínez López, M. A. (2013). The squatters' movement in Europe: A durable struggle for social autonomy in urban politics. Antipode, 45(4), 866-887.

Massey, D. (2004). Geographies of responsibility. Geografiska Annaler, Series B: Human Geography, 86(1), 5-18.

Massey, D. (2005). throwntogetherness: the politics of the event of place. In for space (pp. 149-162). London: Sage.EDITORS?

Mattsson, P. (2019, February 17). Antalet utsatta EU-medborgare har inte minskat. SVT Nyheter, pp. 18-20. Retrieved from https://www.svt.se/nyheter/inrikes/antalet-utsatta-eu-medborgare-har-inteminskat

McClintock, A. (1995). Imperial Leather. London: Routledge.

McCormac, B. (2015, September 25). "Inte acceptabelt att bo på annans mark". SVT Nyheter, pp. 1-3. Retrieved from https://www.svt.se/opinion/fastighetsagarnaom-uppdrag-granskning

McDonald, J. (2012). Building a sanctuary city: municipal migrant rights in the city of Toronto. In P. Nyers \& K. Rygiel (Eds.), Citizenship, Migrant Activism and the Politics of Movement. London: Routledge.

McGarry, A. (2010). Who Speaks for Roma? Political Representation of a Transnational Minority Community. London: Bloomsbury Publishing.

McGarry, A. (2014). Roma as a political identity: Exploring representations of Roma in Europe. Ethnicities, 14(6), 756-774.

Meehan, E. (1993). Citizenship And The Community. London: Sage Publications.

Mendez, K. (2015, October 29). Debattinlägg: "En del av Sveriges rasistiska historia reproduceras nu." Sydsvenskan.

Mesic, N. (2016). Paradoxes of European free movement in times of austerity The role of social movement actors in framing the plight of Roma berry pickers in Sweden. International Journal of Sociology and Social Policy, 36(5-6), 289-303. 
Michanek, G., \& Zetterberg, C. (2017). Den svenska miljörätten (4th editio). Uppsala: Lustus förlag.

Minca, C. (2015a). Counter-camps and other spatialities. Political Geography, 49, 90-92.

Minca, C. (2015b). Geographies of the camp. Political Geography, 49, 74-83.

Mitchell, D. (1997). The Annihilation of Space by Law. Antipode, 29(3), 303-335.

Mitchell, D. (2000). Cultural Geography: a critical introduction. Malden: Blackwell Publishing. Retrieved from http://discovery.ucl.ac.uk/143752/

Mitchell, D. (2007). The Right to the City: Social Justice and the Fight for Public Space. New York; London: The Guilford Press.

Mitchell, D., \& Heynen, N. (2009). The Geography of Survival and the Right to the City: Speculations on Surveillance, Legal Innovation, and the Criminalization of Intervention. Urban Geography, 30(6), 611-632.

Mohtadi, L. (2012). Den dag jag blir fri. Stockholm: Natur \& kultur.

Molina, I. (1997). Stadens rasifiering : Etnisk boendesegregation i folkhemmet. $\mathrm{PhD}$ Dissertation. Uppsala University.

Montesino, N. (2002). Zigenarfrågan: Intervention och romantik. Lunds universitet.

Montesino, N., \& Ohlsson Al Fakir, I. (2015). The Prolonged Inclusion of Roma Groups in Swedish Society. Social Inclusion, 3(5), 126.

Moore, A. (2008). Rethinking scale as a geographical category: From analysis to practice. Progress in Human Geography, 32(2), 203-225.

Moore, D. S., Pandian, A., \& Kosek, J. (2003). Introduction: The Cultural Politics of Race and Nature: Terrains of Power and Practice. In D. S. Moore, J. Kosek, \& A. Pandian (Eds.), Race, Nature and the Politics of Difference (pp. 1-70). Durham and London: Duke University Press.

Morell, I. A. (2018). 'Solidarity not alms': Civil rights movements contesting the evictions and denial of social rights from vulnerable European Union citizens in Sweden. Local Economy: The Journal of the Local Economy Policy Unit, 33(2), 147-171.

Motomura, H. (2008). Immigration Outside the Law. Columbia Law Review, 108, 2037-2097.

Mountz, A. (2002). Feminist Politics, Immigration, and Academic Identities. Gender, Place \& Culture, 9(2), 187-194.

Mountz, A. (2010). Seeking Asylum: Human smuggling and bureaucracy at the border. University of Minnesota Press.

Moyn, S. (2018). Not Enough: Human rights in an unequal world. Cambridge: The Belknap Press of Harvard University Press. 
Mukhtar-Landgren, D. (2012). Planering för framsteg och gemenskap - Om den kommunala utvecklingsplaneringens idémässiga förutsättningar. Lund Univeristy.

Mumford, L. (1961). The City in History. New York: Harcourt, Brace and World.

Nader, L. (1969). Up the Anthropologist: Perspectives Gained From Studying Up. In D. Hymes (Ed.), Reinventing Anthropology (pp. 284-311). New York: Vintage Books.

Neocleous, M. (2000). The Fabrication of Social Order: A Critical Theory of Police Power. London: Pluto Press.

Neuwirth, R. (2005). Shadow Cities: A billion squatters, a new urban world. New York: Routledge.

Nguyen, N. (2019). Rethinking activist educational research: definitions, methodologies, and ethics. Critical Studies in Education, 00(00), 1-16.

Nielsen, A. (2016). Challenging Rightlessness: On Irregular Migrants and the Contestation of Welfare State Demarcation in Sweden. PhD Dissertation, Linnaeus University.

Nordfeldt, M. (1999). Hemlöshet $i$ välfärdsstaden: en studie av relationerna mellan socialtjänst och frivilliga organisationer i Stockholm och Göteborg. Ersta Sköndal högskola.

Nordling, V. (2012). Redefining rights through local practices: the example of social support to undocumented migrants. FREIA Working Paper Series.

Nordling, V. (2017). Destabilising Citizenship Practices? Social work and undocumented migrants in Sweden. PhD Disseration. Lund University.

Nyers, P. (2010). No one is illegal between city and nation. Studies in Social Justice, $4(2), 127-143$.

Nygren, K. G., \& Nyhlén, S. (2017). Normalising welfare boundaries: A feminist analysis of Swedish municipalities' handling of vulnerable EU citizens. Társadalmi Nemek Tudománya Interdiszciplináris EFolyóirat (Interdisciplinary EJournal of Gender Studies), 7(2), 24-40.

O’Nions, H. (2007). Minority Rights Protection in International Law: The Roma of Europe. London: Routledge.

O'Nions, H. (2011). Roma Expulsions and Discrimination: The Elephant in Brussels. European Journal of Migration \& Law, 13(4), 361-388. https://doi.org/10.1163/157181611X605864

Ocobock, P. R. (2009). Vagrancy and Homelessness in Global and Historical Perspective. In A. L. \& P. R. Ocobock (Eds.). Cast out: vagrancy and homelessness in global and historical perspective. Athens: Ohio University Press. 
Ohlsson Al Fakir, I. (2015a). Nya rum för socialt medborgarskap: om vetenskap och politik $i$ "Zigenarundersökningen" - en socialmedicinsk studie av svenska romer 1962-1965. PhD Dissertation. Linnaeus University.

Ohmae, K. (1990). The Borderless World: Power and Strategy in the Interlinked Economy. London: Harper Collins.

Öhrström, M. (2016, February 18). Gör det enklare att avhysa vid illegala boplatser. Svenska Dagbladet.

Olausson, S., \& Iosif, F. (2015). Det kunde varit jag. Stockholm: Kartago.

Oldberg, E. (2016). Jag är Gina: en berättelse om överlevnad och skam i Europa. Stockholm: Leopard.

Olsson Al Safandi, M. (2015, November 5). "Ledarsidor, som tidigare betraktat andra länders avhysningar av romer som skandalösa, anser det nu vara 'rätt och riktigt'.” Sydsvenskan. Retrieved from https://www.sydsvenskan.se/2015-1105/ledarsidor-som-tidigare-betraktat-andra-landers-avhysningar-av-romer-somskand

Olsson, M. (2015, January 25). Dags för krafttag mot tiggeriet. Skånska Dagbladet.

Omar, S. H. (2015, June 22). Ica-butiken slängde allt de hade. Sydsvenskan. Retrieved from https://www.sydsvenskan.se/2015-06-22/ica-butiken-slangde-alltde-hade

Ovesen, L. (2014, November 26). Bråk om resurser när utsatta grupper söker hjälp. SVT Nyheter, pp. 1-2. Retrieved from https://www.svt.se/nyheter/lokalt/skane/brak-om-resurser-nar-rumaner-sokerhjalp

Ovesen, L. (2018, March 28). Stjernfeldt Jammeh (S) om en ebo-begränsning: Ett välkommet besked. Sydsvenskan. Retrieved from https://www.svt.se/nyheter/lokalt/skane/stjernfeldt-jammeh-s-om-en-ebobegransning-ett-valkommet-besked

Palmkvist, J. (2015, March 26). Rädda migranter ger svaga vittnesmål. Sydsvenskan . Retrieved from https://www.sydsvenskan.se/2015-03-26/radda-migranter-gersvaga-vittnesmal

Park, K.-S. (2019). Self-deportation Nation. Harvard Law Review, 132, 1878-1941.

Parker, O. (2012). Roma and the Politics of EU Citizenship in France: Everyday Security and Resistance. Journal of Common Market Studies, 50(3), 475-491.

Parker, O., \& Toke, D. (2013). The Politics of a Multi-level Citizenship: French Republicanism, Roma Mobility and the EU. Global Society, 27(3), 360-378. 
Parsberg, C. (2016). How Do You Become a Successful Beggar in Sweden? An inquiry into the images ofbegging and giving 2011 to 2016. PhD Dissertation. Malmö Faculty of Fine and Performing Arts, Lund University.

Paulsson, A. (2015, January 24). ”Det finns inget facit”. Fria Tidningen.

Pedersen, H. (2014, November 4). Ilska mötte politiker i hård tiggardebatt. Sydsvenskan. Retrieved from https://www.sydsvenskan.se/2014-11-04/ilskamotte-politiker-i-hard-tiggardebatt

Pengelly, M. (2019, April 14). Trump fixed on sanctuary city idea amid opposition and doubts over legality. The Guardian. Retrieved from https://www.theguardian.com/us-news/2019/apr/14/trump-sanctuary-city-ideamigrants

Peroni, L., \& Timmer, A. (2013). Vulnerable groups: The promise of an emerging concept in European Human Rights Convention law. International Journal of Constitutional Law, 11(4), 1056-1085.

Persdotter, M., \& Ericsson, M. (2016). Romer - en svensk historia. Tidskriften Arena, (2).

Persson, Andreas. (2015, November 4). EU-migranter erbjuds inget nytt boende Sydsvenskan. Sydsvenskan. Retrieved from https://www.sydsvenskan.se/201511-04/eu-migranter-erbjuds-inget-nytt-boende?redirected=1

Persson, Ann. (2010, September 4). Sverige utvisar också romer. Dagens Nyheter, p. 9. Retrieved from http://www.dn.se/nyheter/sverige/sverige-utvisar-ocksa-romer/

Picker, G. (2017). Racial cities. Governance and the segregation of Romani people in urban Europe. Taylor \& Francis.

Picker, G., Greenfields, M., \& Smith, D. (2015). Colonial refractions: the 'Gypsy camp' as a spatio-racial political technology. City, 19(5), 741-752.

Picker, G., Murji, K., \& Boatcă, M. (2019). Racial urbanities : towards a global cartography Racial urbanities : towards a global cartography, 4630.

Polismyndigheten. (2015). Polisens möjligheter att hantera olovliga bosättningar.

Polismyndigheten NOA. (2015). Nationell lägesbild: Brottslighet med koppling till tiggeri och utsatta EU-medborgare i Sverige.

Pott, A., Rass, C., \& Wolff, F. (2018). Was ist ein Migrationsregime?: What is a migration regime?. Springer VS.

Powell, R., \& Lever, J. (2017). Europe's perennial 'outsiders': A processual approach to Roma stigmatization and ghettoization. Current Sociology, 65(5), 680-699. 
Powell, Ryan. (2013). Loïc Wacquant's "Ghetto" and Ethnic Minority Segregation in the UK: The Neglected Case of Gypsy-Travellers. International Journal of Urban and Regional Research,37(1), 115-134.

Powell, R., \& van Baar, H. (2019). The Invisibilization of Anti-Roma Racisms. In The Securitization of the Roma in Europe (pp. 91-113). Palgrave Macmillan, Cham.

Pred, A. (1997). Somebody Else, Somewhere Else: Racialized Spaces and the Popular Geographic Imagination in Sweden. Antipode, 29(4), 383-416.

Price, J. (2014). The hostile environment. In B. Anderson \& M. Keith (Eds.), Migration: The COMPAS Anthology. Oxford: COMPAS.

Pries, J. (2017). Social Neoliberalism through Urban Planning: Bureaucratic Formations and Contradictions in Malmö since 1985. PhD Dissertation. Lund University.

Prior, J., Boydell, S., \& Hubbard, P. (2012). Nocturnal Rights to the City: Property, Propriety and Sex Premises in Inner Sydney. Urban Studies, 49(8), 1837-1852.

Proudfoot, J., \& McCann, E. J. (2008). At Street Level: Bureaucratic Practice in the Management of Urban Neighborhood Change. Urban Geography, 29(4), 348370 .

Pruijt, H. (2013). The Logic of Urban Squatting. International Journal of Urban and Regional Research, 37(1), 19-45.

Purcell, M. (2003). Islands of practice and the Marston/Brenner debate: Toward a more synthetic critical human geography. Progress in Human Geography, 27(3), 317-332.

Pusca, A. (2010). The 'Roma Problem' in the EU. Nomadism, (In)visible architectures and Violence. Borderlands E-Journal, 9(2), 1-17.

Quensel, A.-S., \& Vergara, D. (2014, September). Mordbränder och våld mot EUmigranter. EXPO. Retrieved from https://expo.se/2014/09/mordbränder-och-våldmot-eu-migranter

Ramel, F., \& Szoppe, A. (2014, July 16). EU-migrant ett problematiskt begrepp. Sveriges Radio.

Ranasinghe, P., \& Valverde, M. (2006). Governing Homelessness through LandUse: A Sociolegal Study of the Toronto Shelter Zoning By-Law. The Canadian Journal of Sociology, 31(3), 325-349.

Ravnbøl, C. I. (2015). Hjem og arbejde for hjemløse og arbejdsløse EU medborgere: rumænske romaers erfaringer fra København og Malmø. Socialmedicinsk Tidskrift, 92(3), 326-334. 
Ravnbøl, C. I. (2018). Bottle Hunters: An Ethnography of Law and Life Among Homeless Roma in Copenhagen. PhD Dissertation. University of Copenhagen.

Remiche, A. (2012). Yordanova and others v bulgaria: The influence of the social right toadequate housing on the interpretation of the civil right to respect for one's home. Human Rights Law Review, 12(4), 787-800.

Riles, A. (2005). A new agenda for the cultural study of law: Taking on the technicalities. Buffalo Law Review, 53, 973-1033.

Roos, J. (2018a). The Platz I. Göteborg: Self-published by author.

Roos, J. (2018b). The Platz II. Göteborg: Self-published by author.

Rose, N. (1999). Powers of Freedom: Reframing political thought. Cambridge: Cambridge University Press.

Rose, N., \& Miller, P. (1992). Political power beyond the State: problematics of government. 1992. The British Journal of Sociology, 43(2), 173-205.

Rose, N., \& Miller, P. (2008). Introduction. In N. Rose \& P. Miller (Eds.), Governing the Present: Administering Economic, Social and Personal Life (pp. 1-25). Polity Press.

Rose, N., O'Malley, P., \& Valverde, M. (2006). Governmentality. Annual Review of Law and Social Science, 2(1), 83-104.

Roy, A. (2004). Transnational Trespassings: The Geopolitics of Urban Informality. In A. Roy \& N. AlSayyad (Eds.), Urban Informality: Transnational Perspectives from the Middle East, Latin America and South Asia (pp. 289-318). Lanham; Boulder; New York; Toronto; Oxford: Lexington Books.

Roy, A. (2005). Urban informality: toward an epistemology of planning. Journal of the American Planning Association, 71(2), 147-158.

Roy, A. (2009). Why India cannot plan its cities: Informality, insurgence and the idiom of urbanization. Planning Theory, 8(1), 76-87.

Rygiel, K. (2011). Bordering solidarities: Migrant activism and the politics of movement and camps at Calais. Citizenship studies, 15(01), 1-19.

Rygiel, K. (2012). Politicizing camps: forging transgressive citizenships in and through transit. Citizenship Studies, 16(5-6), 807-825.

Saarinen, M. (2015, October 31). Valfridsson: Nolltolerans mot tiggares läger. Sveriges Radio P1.

Sager, M. (2011). Everyday clandestinity: Experiences on the margins of citizenship and migration policies. PhD Dissertation. Lund University.

Sahlin, I. (1996). På gränsen till bostad: avvisning, utvisning, specialkontrakt. Lund: Arkiv förlag. 
Sahlin, I. (2004). Constructing Victims and Villains: Unintended Outcomes of Contact Prohibition Orders. Journal of Scandinavian Studies in Criminology and Crime Prevention, 5(1), 85-107.

Sahlin, I. (2013). Bostadslöshet som politiskt resultat. Fronesis, (42-43), 53-64.

Sandland, R. (2008). Developing a jurisprudence of difference: The protection of the Human Rights of Travelling Peoples by the European Court of Human Rights. Human Rights Law Review, 8(3), 475-516.

Santos, B. de S. (1987). Law : A Map of Misreading . Toward a Postmodern of Conception of Law. Journal of Law and Society, 14(3), 279-302.

Sassen, S. (2013). When the center no longer holds: Cities as frontier zones. Cities, $34,67-70$.

Schclarek Mulinari, L. (2015). Ni är inte välkomna i vårt fina Malmö : Premisser för samhällsgemenskap i kamp mot organiserad brottslighet. Sociologisk Forskning, 52(4), 321-340.

Schclarek Mulinari, L. (2017). Contesting Sweden's Chicago: why journalists dispute the crime image of Malmö. Critical Studies in Media Communication, 34(3), 206-219.

Schierup, C. U., Ålund, A., \& Neergaard, A. (2018). "Race" and the upsurge of antagonistic popular movements in Sweden. Ethnic and Racial Studies, 41(10), $1837-1854$.

Scott, J. C. (1998). Seeing Like a State: How certain schemes to improve the human condition have failed. New Haven: Yale University Press.

Selling, J. (2013). Svensk antiziganism (1st ed.). Limhamn: Sekel.

Shumsky, N. L. (2008). Noah Webster and the Invention of Immigration. The New England Quarterly, 81(1), 126-135.

Sibley, D. (1995). Geographies of Exclusion. London: Routledge.

Sigona, N. (2014). Campzenship: reimagining the camp as a social and political space. Citizenship Studies, 19(1), 1-15.

Sigona, N., \& Trehan, N. (2009). Romani politics in contemporary Europe: poverty, ethnic mobilization, and the neoliberal order. Basingstoke: Palgrave Macmillan.

Simons, H. (2014). Case Study Research in Practice. London: Sage Publications.

Skåne Stadsmission. (2018). Hemlösheten ökar - men Nattjouren måste stänga [press release]. Retrieved from https://www.skanestadsmission.se/hemloshetenokar-men-nattjouren-maste-stanga/

Smith, D. (1976). To what extent is the geographer's world the "real world" invited comment. Area, 83-84. 
Smith, N. (1996). The New Urban Frontier. Gentrification and the Revanchist City. New York: Routledge.

Sociala resursförvaltningen. (2016). Återrapportering gällande arbetet med EUmedborgare $i$ socialt och ekonomiskt utsatta situationer.

Socialstyrelsen. (2014). Rätten till socialt bistånd för medborgare inom EU/EESområdet: Em vägledning.

Socialstyrelsen. (2017a). Hemlöshet 2017 - omfattning och karaktär.

Socialstyrelsen. (2017b). Vägledning för socialtjänsten i arbetet med EU/EESmedborgare - EU/EES-medborgares rätt till socialt bistånd.

Sohl, L. (2018). Feel-bad moments: Unpacking the complexity of class, gender and whiteness when studying 'up.' European Journal of Women's Studies, 25(4), $470-483$.

Solimene, M. (2011). 'These Romanians have ruined Italy'. Xoraxané Romá, Romanian Roma and Rome. Journal of Modern Italian Studies, 16(5), 637-651.

Solimene, M. (2013). Undressing the gă̆é clad in state garb: Bosnian xoraxané romá face to face with the Italian authorities. Romani Studies, 23(2), 161-186.

SOU 2016:6. (2016). Framtid sökes - Slutredovisning från den nationella samordnaren för utsatta EU-medborgare. Retrieved from http://www.regeringen.se/contentassets/b9ca59958b5f43f681b8ec6dba5b5ca3/fra mtid-sokesslutredovisning-fran-den-nationella-samordnaren-for-utsatta-eumedborgare-sou-2016_6.pdf

Spehar, A., Hinnfors, J., \& Bucken-Knapp, G. (2017). Passing the Buck: The case of failing multilevel governance and vulnerable EU migrants in Sweden. Nordic Journal of Migration Research, 7(2), 114-124.

Squire, V., \& Darling, J. (2013). The "Minor" Politics of Rightful Presence: Justice and Relationality in City of Sanctuary. International Political Sociology, 7(1), 59-74.

Stallybrass, P., \& White, A. (1986). The Politics and Poetics of Transgression. London: Methuen.

Stauffer, J. (2015, November 6). Malmö stad har inte tagit sitt ansvar. Dagens Samhälle. Retrieved from https://www.dagenssamhalle.se/debatt/malmoe-stadhar-inte-tagit-sitt-ansvar-19867

Stockholms Stadsmission. (2012). Hemlös 2012. Retrieved from https://www.stadsmissionen.se/sites/default/files/files/Hemlös $2012 \mathrm{EU}$ Medborgare som lever i hemlöshet i Sverige.pdf

Strange, M., \& Lundberg, A. (2014). Education as Hospitality. Peace Review, 26(2), 201-208. 
Strömberg, L. (2015, July 9). Kronofogden utreder avhysning där EU- migranterna campar. Sveriges Radio. Retrieved from https://sverigesradio.se

Stryker, R., \& González, R. (Eds.). (2014). Up, Down, and Sideways: Anthropologists Trace the Pathways of Power. Berghan Books.

Students of Ethnographic \& Qualitative Methods at the Eugene Lang College at the New School. (2018). An Open Letter to Alice Goffman. Retrieved from http://www.publicseminar.org/2018/05/an-open-letter-to-alice-goffman/

Surdu, M. (2016). Those who count: expert practices of Roma classification. Budapest: Central European University Press.

Surdu, M., \& Kovats, M. (2015). Roma Identity as an Expert-Political Construction. Social Inclusion, 3(5), 2183-2803.

Sveriges Kommuner och Landsting. (2014). Enkätsvar från kommunerna om EU/ESS-medborgare i akut hemlöshet. Retrieved from https://skl.se/download/18.32ed962b14a4d52a261aca3/1418825455827/sklenkat-utsattaEUmedborgare.pdf

Sveriges Radio. (2011, March 8). Gatumusiker utvisades utan laglig grund. Sveriges Radio. Stockholm. Retrieved from http://sverigesradio.se/sida/artikel.aspx?programid=103\&artikel=4388823

SVT Nyheter. (2015, November 3). Stefan Löfven: Migranterna är hemländernas ansvar. SVT Nyheter, pp. 1-2. Retrieved from https://www.svt.se/nyheter/inrikes/stefan-lofven-migranterna-ar-sina-hemlandersansvar

Swärd, H. (2008). Att bekämpa fattigdom med lagar för fattiga - en omöjlig ekvation. In H. Swärd \& M.-A. Egerö (Eds.), Villkorandets politik : fattigdomens premisser och samhällets åtgärder - då och nu. (pp. 17-41) Malmö: Egalité.

Swyngedouw, E. (1996). Urban Studies Reconstructing Citizenship, the Re-scaling of the State and the New Authoritarianism: Closing the Belgian Mines. Urban Studies, 33(8), 1499-1522.

Sylvestre, M. E., Damon, W., Blomley, N., \& Bellot, C. (2015). Spatial Tactics in Criminal Courts and the Politics of Legal Technicalities. Antipode, 47(5), 13461366.

Szoppe, A., \& Gustafsson, A. (2014, March 25). Ullenhag: "Vitboken är en ursäkt." Sveriges Radio. Retrieved from https://sverigesradio.se

Taikon, K., \& Langhammer, B. (1967). Zigenare är vi. Stockholm: Tiden.

Tervonen, M. (2010). 'Gypsies', Travellers' and 'peasants'. A study on ethnic boundary drawing in Finland and Sweden, c.1860-1925. PhD Dissertation. European University Institute. 
Tervonen, M., \& Enache, A. (2017). Coping with everyday bordering: Roma migrants and gatekeepers in Helsinki. Ethnic and Racial Studies, 40(7), 11141131.

Thörn, C. (2011). Soft Policies of Exclusion: Entrepreneurial Strategies of Ambience and Control of Public Space in Gothenburg, Sweden. Urban Geography, 32(7), 989-1008.

Tilly, C., \& Blockmans, W. P. (1994). Cities and the rise of states in Europe, A.D. 1000 to 1800. Boulder, Colorado: Westview Press.

Torpey, J. (1998). Coming and Going: On the State Monopolization of the Legitimate "Means of Movement." Sociological Theory, 16(3), 239-259.

Torpey, J. (2000). The Invention of the Passport: Surveillance, citizenship and the state. Cambridge: Cambridge University Press.

Tremlett, A. (2014). Making a difference without creating a difference: Superdiversity as a new direction for research on Roma minorities. Ethnicities, 14(6), 830-848.

Tyler, I. (2009). Against abjection. Feminist Theory, 10(1), 77-98.

Uitermark, J., \& Nicholls, W. (2014). From Politicization to Policing: The Rise and Decline of New Social Movements in Amsterdam and Paris. Antipode, 46(4), 970-991.

United Nations Human Rights Office of the High Commissioner. (2015). Joint Urgent Appeal from Special Procedures [regarding the demolition of the Sorgenfri-camp]. Retrieved from http://blogg.socialarattigheter.se/wpcontent/uploads/2015/11/Brev-fr\%C3\%A5n-specialrapport\%C3\%B6renf\%C3\%B6r-minoritetsfr\%C3\%A5gor151030.pdf

Valverde, M. (2003). Law's dream of a common knowledge. Princeton University Press.

Valverde, M. (2005). Taking "land use" seriously: toward an ontology of municipal law. Law Text Culture, 9(1), 34-59.

Valverde, M. (2009a). Jurisdiction and Scale: Legal "Technicalities" as Resources for Theory. Social \& Legal Studies, 18(2), 139-157.

Valverde, M. (2009b). Laws of the Street. City \& Society, 21(2), 163-181.

Valverde, M. (2010). Practices of Citizenship and Scales of Governance. New Criminal Law Review: An International and Interdisciplinary Journal, 13(2), 216-240.

Valverde, M. (2011). Seeing Like a City: The Dialectic of Modern and Premodern Ways of Seeing in Urban Governance. Law and Society Review, 45(2), 277-312. 
Valverde, M. (2015). Chronotopes of Law: Jurisdiction, Scale and Governance. New York: Routledge.

Valverde, M. (2016). Beyond the Social Control of Space : Towards a Multidimensional Approach to Local Security Networks. In B. Bradford, B. Jauregui, I. Loader, \& J. Steinberg (Eds.), The SAGE Handbook of Global Policing (pp. 46-60).

van Baar, H. (2011). The European Roma: Minority representation, memory, and the limits of transnational governmentality. PhD Dissertation. Universiteit van Amsterdam.

van Baar, H. (2015a). The Hidden Dimension of "The Refugee Crisis": Racializing Poverty and Bordering Europe Biopolitically. Lecture held at Freiburg University 11 (2015). Available at http://www.academia.edu/download/40370642/van_Baar_2015__The_Hidden_Dimension_of_the_Refugee_Crisis_-_Freiburg.pdf

van Baar, H. (2015b). The Perpetual Mobile Machine of Forced Mobility: Europe's Roma and the Institutionalization of Rootlessness. In Y. Jansen, R. Celikates, \& J. de Bloois (Eds.), The Irregularization of Migration in Contemporary Europe: Deportation, Detention, Drowning (pp. 71-86). London: Rowman and Littlefield Interntional.

van Baar, H. (2017a). Boundary practices of citizenship: Europe's Roma at the nexus of securitization and citizenship. In R. G. Gonzales \& N. Sigona (Eds.).Within and beyond Citizenship: Borders, Membership and Belonging. (pp. 143-158) London: Routledge.

van Baar, H. (2017b). Contained mobility and the racialization of poverty in Europe: The Roma at the development-security nexus. Social identities, 24(4), 442-458.

van Baar, H. (2017c). Evictability and the Biopolitical Bordering of Europe. Antipode, 49(1), 212-230.

van Baar, H., Ivasiuc, A., \& Kreide, R. (Eds.) (2019a). The European Roma and Their Securitization: Contexts, Junctures, Challenges Palgrave Macmillan, Cham.

Varsanyi, M. W. (2006). Interrogating "Urban Citizenship" vis-à-vis Undocumented Migration. Citizenship Studies, 10(2), 229-249.

Varsanyi, M. W. (2008). Immigration Policing Through the Backdoor: City Ordinances, the "right to the City," and the Exclusion of Undocumented Day Laborers. Urban Geography, 29(1), 29-52.

Varsanyi, M. W. (2010a). City Ordinances as "Immigration Policing by Proxy": Local governments and the regulation of undocumented day laborers. In M. W. 
Varsanyi (Ed.), Taking Local Control: Immigration policy activism in U.S. cities and states (pp. 135-156). Stanford: Stanford University Press.

Varsanyi, M. W. (Ed.). (2010b). Taking Local Control: Immigration Policy Activism in U.S. Cities and States. Stanford: Stanford University Press.

Vasudevan, A. (2015). The makeshift city: Towards a global geography of squatting. Progress in Human Geography, 39(3), 338-359.

Vermeersch, P. (2006). The Romani movement: minority politics and ethnic mobilization in contemporary Central Europe. Oxford: Berghan.

Vermeersch, P. (2012). Reframing the Roma: EU Initiatives and the Politics of Reinterpretation. Journal of Ethnic and Migration Studies, 38(8), 1195-1212.

Vermeersch, P., \& van Baar, H. (2017). The Limits of Operational Representations. Intersections, 3(4), 120-139.

Vrăbiescu, I. (2019a). The state riddle: working through messiness alongside a shared deportation apparatus in France and Romania. Social Anthropology, 27, 33-48.

Vrăbiescu, I. (2019b). Voluntary Return as Forced Mobility: Humanitarianism and the Securization of Romani Migrants in Spain. In H. van Baar, A. Ivasiuc, \& R. Kreide (Eds.), The Securitization of the Roma in Europe (pp. 207-229). Cham, Switzerland: Palgrave Macmillan.

Wacquant, L. (2001). Deadly Symbiosis: When ghetto and prison meet and mesh. Punishment \& Society, 3(1), 95-134.

Wacquant, L. (2009). Punishing the Poor: the neoliberal government of social insecurity. Durham, N.C.: Duke University Press.

Wacquant, L. (2011). A janus-faced institution of ethnoracial closure: a sociological specification of the ghetto. The ghetto: contemporary global issues and controversies. Retrieved from http://www.loicwacquant.net/assets/Papers/JANUSFACEDINSTITUTIONProofs.pdf

Wacquant, L. (2014). Marginality, ethnicity and penality in the neo-liberal city: an analytic cartography. Ethnic and Racial Studies, 37(10), 1687-1711.

Waldron, J. (1991). Homelessness and the Issue of Freedom. UCLA Law Review., 39, 295-324.

Walker, K. E., \& Leitner, H. (2010). The Variegated Landscape of Local Immigration Policies in the United States. Urban Geography, 31(7), 953-972.

Wallengren, S., \& Mellgren, C. (2015). The role of visibility for a minority's exposure to (hate) crime and worry about crime - a study of the Traveller community. International Review of Victimology, 21(3), 303-319. 
Wallengren, S., \& Mellgren, C. (2017a). Gatans Tysta Offer: En studie av socialt utsatta EU-medborgares utsatthet för brott, hatbrott och annan kränkande behandling $i$ det offentliga rummet. Malmö högskola: Institutionen för kriminologi. Retrieved from www.mah.se/muep

Wallengren, S., \& Mellgren, C. (2017b). Romer upplevelser av hatbrott: Upplevelser, konsekvenser och stöd (FoU repport 2017:3). Retrieved from www.mah.se/muep

Wallentin, H. (1989). Lösdriveri och industrialism : om lösdriverifrågan i Sverige 1885- 1940. Östersund, Sweden: Högskolan i Östersund

Walters, W. (2002a). Deportation, Expulsion, and the International Police of Aliens. Citizenship Studies, 6(3), 265-292.

Walters, W. (2002b). Mapping Schengenland: Denaturalizing the border. Environment and Planning D: Society and Space, 20(5), 561-580.

Walters, W. (2004). Secure borders, safe haven, domopolitics. Citizenship Studies, $8(3), 237-260$.

Walters, W. (2011). Foucault and frontiers: Notes on the birth of the humanitarian border. In U. Bröckling, S. Krasmann, \& T. Lemke (Eds.), Governmentality: Current Issues and Future Challenges (pp. 138-164). New York: Routledge.

Walters, W. (2015). Reflections on Migration and Governmentality. Movements Journal Für Kritische Migrations- Und Grenzregimeforschung, 1(1), 1-30.

Walters, W., \& Haahr, J. H. (2005). Governing Europe: Discourse, governmentality and European integration. London: Routledge.

Wemyss, G., \& Cassidy, K. (2017). "People think that Romanians and Roma are the same": everyday bordering and the lifting of transitional controls. Ethnic and Racial Studies, 40(7), 1132-1150.

Westerberg, O. (2015, October 27). Ägaren till ockuperade marken : "Vi kan inte ha anarki." Sydsvenskan. Retrieved from https://www.sydsvenskan.se/2015-1027/agaren-till-ockuperade-marken-vi-kan-inte-ha-anarki

Wikström, E. (2015). Fattiga migranter och “det yttersta ansvaret.” In E. Righard \& N. Montesino (Eds.), Socialt arbete och migration (pp. 87-104). Malmö: Gleerups.

Wimmer, A., \& Glick Schiller, N. (2002). Methodological nationalism and beyond : nation-state building, migration and the social sciences, Global Networks, 4 , 301-334.

Winther Jørgensen, M., \& Phillips, L. (2002). Discourse analysis as theory and method. London: Sage. 
Yiftachel, O. (2009a). Critical theory and "gray space": Mobilization of the colonized. City, 13(2-3), 246-263.

Yiftachel, O. (2009b). Theoretical notes on "gray cities": The coming of urban apartheid? Planning Theory, 8(1), 88-100.

Yiftachel, O. (2018). Displaceability - a Southeastern Perspective. Retrieved from http://mitdisplacement.org/symposium-oren-yiftachel

Yıldız, C., \& De Genova, N. (2017). Un / Free mobility : Roma migrants in the European Union. Social Identities, 23(4), 1-17.

Yuval-Davis, N., Wemyss, G., \& Cassidy, K. (2017). Introduction to the special issue: racialized bordering discourses on European Roma. Ethnic and Racial Studies, 40(7), 1047-1057.

Yuval-Davis, N., Wemyss, G., \& Cassidy, K. (2018). Everyday Bordering, Belonging and the Reorientation of British Immigration Legislation. Sociology, 52(2), 228-244.

Zahn, R. (2015). "Common Sense" or a Threat to EU Integration? The Court, Economically Inactive EU Citizens and Social Benefits. Industrial Law Journal, 44(4), 573-585.

Zick, T. (2006). Speech and Spatial Tactics. Texas Law Review, 84((3)), 581-651. 


\section{APPENDIX: “READING GUIDE"}

The following is a reading guide I developed to guide my document analysis. This was a "working tool". Not all questions included in the guide are reflected in the finished analysis.

1. What problematisations features in the material?

a. That is, what is the problem represented to be?

b. How do spatial and geographical concepts, metaphors, and imaginaries factor into the definition and understanding of 'the problem(s)'? Specifically, at what geographical scales are 'the problem(s)' assumed to have originated, and at what scales is it proposed that it be addressed?

c. How does the material refer and relate to other, competing, problematisations?

2. What substance is meant to be governed (e.g., people, place, status, behaviour)?

a. How is the substance, subjects or populations to be governed categorised, and how are their boundaries constructed? (For instance, how are 'vulnerable EUcitizens set apart from other mobile EU-citizens?)

b. If relevant, as what type of legal object is the substance to be governed?

c. What does the categorisation seem to $d o$ ?

3. How, in practical terms, is the substance to be governed; what concrete practices and technologies, tactics and strategies are involved?

a. Are the practices spatial in terms of their mechanics? 
4. What is the jurisdiction? And what is the relationship between various jurisdictions and levels of government, or between government and civil society actors with regards to the specific intervention or practice?

a. Valverde suggests that decisions about jurisdiction (who governs where) effectively decides how governance will happen. Based on the material, what can be said about this?

5. How are questions of ethnicity and race addressed in the material? Are Roma identity categories is conjured up and mobilised or, alternatively, negated and made invisible?

a. What is assumed or said to be constitutive of Roma identities (biology, culture, history, social and political marginalisation, or otherwise)?

b. How does the material relate to questions of discrimination and racism?

c. How does it relate to questions of Roma rights?

d. What is the relationship between racial and spatial categories. 




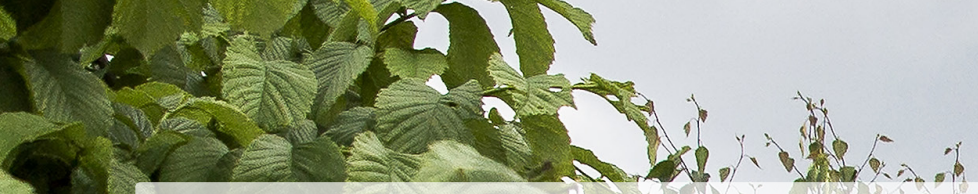

This thesis traces the local government response to the presence of impoverished and street- homeless so-called vulnerable EU-citizens in Malmö, Sweden between the years 2014-2016, and develops an analysis about how bordering takes place in cities.

'Vulnerable EU-citizens' is a term used by the Swedish authorities to refer to citizens of other EU Member States who are staying in Sweden without a right of residence and in situations of extreme poverty and marginality. A majority of those whom are categorised as "vulnerable EU-citizens" are Roma from Bulgaria or Romania.

Based on an in-depth case study of the controversies surrounding the so-called Sorgenfri-camp - an unauthorised settlement of about 200 Romanian Roma - the thesis showcases in detail how legal and administrative procedures, mechanisms and categorisations work in complex ways to manage and govern the unauthorised camp settlements of 'vulnerable EU- citizens'. In doing so, the thesis highlights the city as a space where complex negotiations over residency- status, rights and belonging play out. It submits that local authorities in Malmö have responded to the presence and situation of vulnerable EU-citizens in the city by enacting a series of practices and programs that jointly add up to an indirect policy of exclusionary mobility control, the cumulative effect of which is to eliminate the "geographies of survival" for the group in question. Furthermore, it argues that this reinforces the complex modulations of un/free mobility" in the EU: destitute EU-citizens who are formally free to move and reside within the union are repeatedly moved along, and thus effectively prevented from settling. This is taken to be illustrative of an urbanisation of mobility control practices: a convergence between mobility control and urban socio-spatial control, or a rescaling of mobility control from the edges of the nation-state to the urban scale and, ultimately, to the body of the "vulnerable EU-citizen".
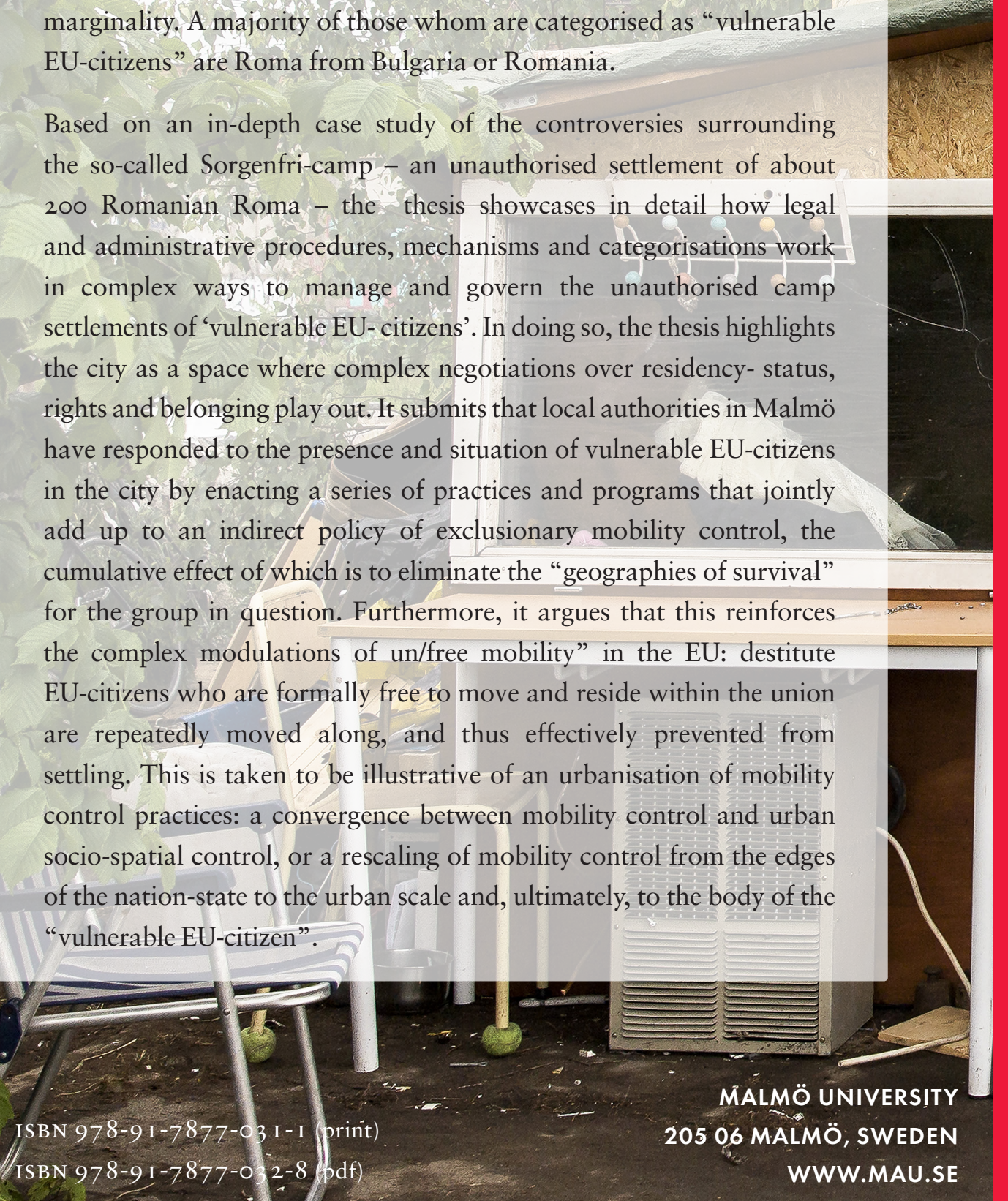